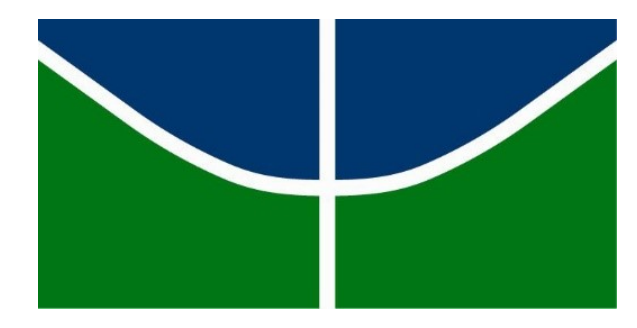

\author{
UNIVERSIDADE DE BRASÍLIA \\ FACULDADE DE CIÊNCIA DA INFORMAÇÃO \\ PROGRAMA DE PÓS-GRADUAÇÃO EM CIÊNCIA DA INFORMAÇÃO
}

ANA MARIA DE ALMEIDA RIBEIRO

Organização e Acesso à Informação na Empresa Brasileira de Correios e Telégrafos após Promulgação da Lei de Acesso à Informação

Brasília

2016 


\section{Organização e Acesso à Informação na Empresa Brasileira de Correios e Telégrafos após Promulgação da Lei de Acesso à Informação}

Dissertação de Mestrado apresentada ao Programa de Pós-Graduação em Ciência da Informação da Universidade de Brasília como requisito para obtenção do título de Mestre em Ciência da Informação.

Área de concentração:

Gestão da Informação

Linha de pesquisa:

Organização da Informação

Orientadora: Prof. ${ }^{a}$ Dra. Eliane Braga de Oliveira

\section{Brasília}


Ficha catalográfica elaborada automaticamente, com os dados fornecidos pelo(a) autor(a)

RIBEIRO, ANA MARIA DE ALMEIDA

RAN533

Organização e Acesso à Informação na Empresa

Brasileira de Correios e Telégrafos após Promulgação da Lei de Acesso à Informação / ANA MARIA DE ALMEIDA RIBEIRO; orientador ELIANA BRAGA DE OLIVEIRA. -Brasília, 2016.

$282 \mathrm{p}$.

Dissertação (Mestrado - Mestrado em Ciência da Informação) -- Universidade de Brasília, 2016.

1. Lei de Acesso à Informação. 2. Organização da Informação. 3. Empresa Estatal. 4. Transparência Pública. 5. Empresa Brasileira de Correios e Telégrafos. I. OLIVEIRA, ELIANA BRAGA DE, orient. II. Título. 


\section{FOLHA DE APROVAÇÃO}

Título: "ORGANIZAÇÃO E ACESSO À INFORMAÇÃO NA EMPRESA BRASILEIRA DE CORREIOS E TELÉGRAFOS (ECT) APÓS A PROMULGAÇÃO DA LEI DE ACESSO À INFORMAÇÃO”.

\section{Autor (a): Ana Maria de Almeida Ribeiro}

Área de concentração: Gestão da Informação

Linha de pesquisa: Organização da Informação

Dissertação submetida à Comissão Examinadora designada pelo Colegiado do Programa de Pósgraduação em Ciência da Informação da Faculdade em Ciência da Informação da Universidade de Brasília como requisito parcial para obtenção do título de Mestre em Ciência da Informação.

Brasília, 12 de dezembro de 2016.

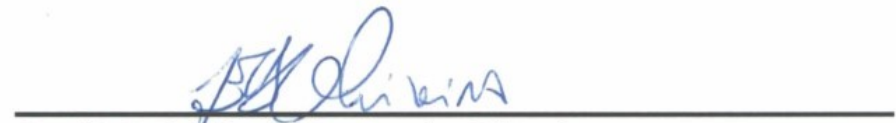

Profa Dra Éliane Braga de Oliveira

Presidente (UnB/PPGCINF)

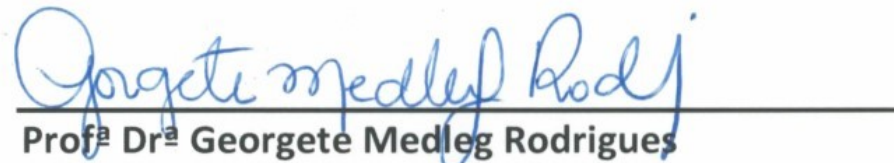

Membro Interno (UnB/PPGCINF)

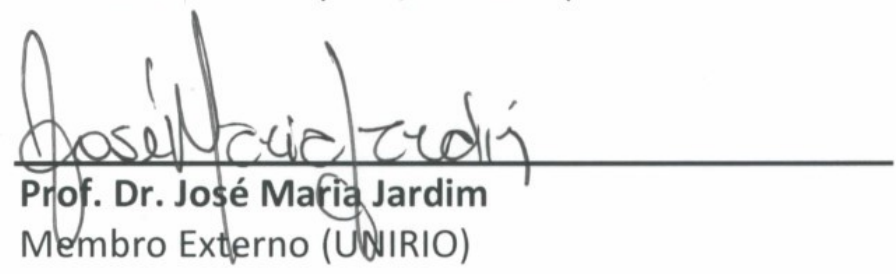

Prof. Dr. Renato Tarciso Barbosa de Sousa

Membro Suplente (UnB/PPGCINF)

Edifício da Biblioteca Central (BCE) - Entrada Leste - Campus Universitário Darcy Ribeiro - Asa Norte - Brasília, DF CEP 70910-900 - Tel.: +55 (61) 3107-2632 - Telefax: +55 (61) 3107-2633 - E-mail: pgcinf@unb.br 
À Luís Inácio Lula da Silva e Dilma Rousseff por serem lutadores de verdade e investirem na educação no Brasil.

Aos meus amigos Nina, Américo, Neide, Nazaré, Janete, Crê, Viviane e Edson pela força, estimulo, carinho, espaço de conversa e discussão intelectual, nessa decisão e caminhada.

À minha mãe Elvira de Jesus Almeida Ribeiro, (in memoriam), que tenho certeza, me acompanha a cada passo que dou na vida.

Ao meu filho Leonardo, razão do meu viver, minha irmã Fernanda e meu cunhado Júlio pelo amor que temos e pela família que somos. 


\section{AGRADECIMENTOS}

Os agradecimentos se fazem necessários depois do extenso processo de construção até chegar neste momento. Se por um lado, a academia o avalia pela elaboração individual como aluno, por outro, essa elaboração não seria possível se um conjunto de pessoas e premissas não estivessem presentes. Ainda mais, quando se toma essa decisão após meio século de vida.

Primeiramente, agradeço ao povo brasileiro que com coragem e confiança votou por quatro vezes seguida em um projeto inclusivo, permitindo Luís Inácio Lula da Silva e Dilma Rousseff presidirem o nosso país e implementar políticas de transparência pública e de valorização do ensino superior no Brasil.

À minha orientadora, Profa. Eliane Braga de Oliveira que me recebeu carinhosamente, sem me conhecer, sem saber minhas origens, minha formação. Sempre esteve à disposição quando precisei, com quem me apropriei de conceitos da arquivologia que desconhecia. Adorei estar com você e que nossa amizade se mantenha para sempre, muito obrigada.

Agradeço à Profa. Dra. Georgete Medleg Rodrigues e ao Prof. Dr. José Maria Jardim pela disponibilidade em comporem a banca de Mestrado e pelas orientações no relatório intermediário, de imensa valia.

À Empresa Brasileira de Correios e Telégrafos que me fez o convite e me proporcionou o espaço para essa pesquisa e, ao ser selecionada como bolsista, me permitiu liberação para o cumprimento dos créditos na UnB.

Agradeço ao Professor Aloisio Teixeira (in memoriam), Reitor da Universidade Federal do Rio de Janeiro em 2011, que autorizou minha cessão à Empresa Brasileira de Correios e Telégrafos, permitindo assim conhecer um outro universo da gestão pública. E assim, agradeço à UFRJ por ter sido o espaço em todos esses anos de convívio, de aluna à servidora pública federal, onde conheci o mundo, a liberdade, a ciência, a política, o amor, a luta, a paixão, o socialismo, a revolução, o compromisso, a dedicação e tantos outros conceitos e sentimentos.

Um agradecimento especial ao Professor Doutor Emérito Nelson Souza e Silva, da Faculdade de Medicina da UFRJ, exemplo incansável de luta por essa universidade e sociedade para todos e todas, que tanto me inspira nessa caminhada.

Ao conjunto dos trabalhadores e trabalhadoras dos Correios por terem me recebido, me "aceitado" - frente à conflituosa política aberta de receber servidores de outros órgãos - e me permitido permanecer por cinco anos e três meses e interagir tão fortemente. Neste período desenvolvi os projetos aos quais fui designada a coordenar e são objetos desta pesquisa. Agradeço em especial às amigas Crê Rocha, Viviane Marques, Janete Aguiar, Ana Mergulhão 
pelo carinho e amizade que construímos. Através de Rosicler Moura agradeço a todos que atuaram como Pontos Focais do SIC, e permitiram a excelência de nosso trabalho. Agradeço também a Paulo Teixeira, Jaime Cardoso, Edson Dorta, Luizinho Souza, Manuel Brum, Josiel Reis, Ronny Sávio e, através destes, à tantos outros que mostraram um outro universo da empresa, o "chão de fábrica".

Aos colegas da Controladoria Geral da União, o José Eduardo Elias Romão, Gilberto Waller Junior, respectivamente ex e atual Ouvidor Geral da União, Erica Bezerra e Marcos Lindenmayer, e todo corpo técnico, pelo apoio que recebi no desempenho de minhas atividades.

Agradeço aos meus companheiros e companheiras dos movimentos sociais, estudantil, da UFRJ e das universidades públicas brasileiras, de mais de 35 anos de luta em defesa da democracia e do socialismo, de luta por uma Constituição Cidadã, dos movimentos em defesa do serviço público de qualidade e de inclusão social e tantas outras batalhas. Impossível nomear a todos e todas, por isso agradeço à Rosane Silva grande liderança sindical, e em nome dela a toda essa aguerrida militância.

Um agradecimento especial às Professoras Andréa Teixeira e Sheila Back, da Escola de Serviço Social da UFRJ, pelo apoio nessa reta final, essencial para conclusão deste estudo.

Agradeço à Faculdade de Ciência da Informação da Universidade de Brasília que me recebeu como aluna quando nem mesmo eu achava que era capaz. Prestar um concurso público para ingresso em um mestrado acadêmico, não sendo oriunda da área de Ciência da Informação, e ter obtido a maior nota na prova escrita, foi para mim uma grande vitória pessoal. O convívio com novos colegas e docentes foi um ambiente de acolhida, me senti em casa. À Vivian Miatelo, secretária do Programa que como toda técnica-administrativa comprometida, sempre colaborativa e atenciosa, e aos Professores Jayme Leiro, Miriam Manini e Cynthia Roncaglio, meu muito obrigada por me introduzirem a esse fascinante mundo da Ciência da Informação.

Um agradecimento muito especial a minha amiga e irmã, de coração, Maria do Socorro Gomes, Nina. Muito obrigada pelo afeto, pela amizade, pelo lar, pelo carinho, pela família, por tudo.

E por fim, exatamente porque são os mais importantes na minha vida, o meu filho Leonardo, minha irmã Fernanda e cunhado Júlio, que me deram o necessário suporte para sobreviver a distância, o apoio nos momentos mais difíceis, e o amor necessário como o oxigênio para se viver. Amo vocês! 
"Isso de entregar-se por inteiro às misérias de cada dia que passa é coisa inconcebível e intolerável para mim...precisamente um lutador é quem mais tem que esforçar-se para ver as coisas de cima, caso não queira encarar a cada passo todas as mesquinharias e misérias..., sempre e quando, naturalmente, se trate de um lutador de verdade."

Rosa Luxemburgo

“É preciso sonhar, mas com a condição de crer em nosso sonho, de observar com atenção a vida real, de confrontar a observação com nosso sonho, de realizar escrupulosamente nossas fantasias. Sonhos, acredite neles." 


\section{RESUMO}

A Empresa Brasileira de Correios e Telégrafos (ECT) foi criada em 1969, no período da Ditadura Militar (1964-1985), como empresa pública de direito privado no âmbito da Administração Pública Indireta no Brasil. Em função do modelo gerencial adotado não houve uma organização da informação eficiente, cujos reflexos foram percebidos nos três primeiros anos de implantação da Lei de Acesso à Informação (LAI), implantada no Brasil em maio de 2012. A dissertação faz uma análise da organização e do acesso à informação no âmbito da ECT após a promulgação da LAI. Apresentaremos elementos que identificam o compromisso social de práticas e saberes da Ciência da Informação, a importância do seu desenvolvimento vinculada à sociedade que lhe cerca, destacando a LAI, como instrumento de democratização do Estado e da necessidade de uma organização da informação na ECT para uma gestão democrática. Caracteriza-se como uma pesquisa aplicada de caráter descritivo com uma abordagem qualitativa. As técnicas para coleta de dados são a pesquisa bibliográfica, a análise dos pedidos de informação registrados no Sistema de Informação ao Cidadão (e-SIC), a observação, a análise de documentos da empresa e do questionário aplicado à empregados. A não divulgação da base de dados do Código de Endereçamento Postal (CEP) e dos os salários dos empregados, a necessidade de adoção de linguagem amigável ao cidadão para divulgação das informações, a avaliação dos empregados e dos cidadãos são alguns dos dados analisados. Os resultados apontam que a condição híbrida da empresa - prestação de serviços públicos e exploração de atividade econômica, e que está presente na cultura organizacional da empresa, limita a transparência pública e interfere no cumprimento da LAI, ao restringir o acesso à informação aos cidadãos.

PALAVRAS-CHAVE: Lei de Acesso à Informação. Organização da Informação. Empresa Estatal. Transparência Pública. Empresa Brasileira de Correios e Telégrafos. 


\begin{abstract}
The Brazilian Postal and Telegraph Company (ECT) was created in 1969, during the period of the Military Dictatorship (1964-1985), as a public company under private law under the Indirect Public Administration in Brazil. According to the adopted management model there was an organization of efficient information whose reflexes were seen in the first three years of implementation of the Access to Information Act (LAI), implemented in Brazil in May 2012. The dissertation is an organization analysis and access to information under the ECT following the enactment of LAI. The dissertation analyzes the organization and access to information within the ECT after the enactment of the Law on Access to Information (LAI). We will present elements that identify the social commitment of practices and knowledge of Information Science, the importance of its development linked to the society around it, highlighting LAI as an instrument for democratization of the State and the need for an information organization in the ECT for a Democratic management. It is characterized as a descriptive applied research with a qualitative approach. The techniques for collecting data are bibliographic research, analysis of information requests registered in the Citizen Information System (e-SIC), observation, analysis of company documents and questionnaire applied to employees. The nondisclosure of the Postal Code (Postal Code) database and the salaries of employees, the need to adopt citizen-friendly language for the dissemination of information, and the evaluation of employees and citizens are some of the data analyzed. The results indicate that the company's hybrid condition, public service provision and economic activity exploitation, limits public transparency, is present in the company's organizational culture, and interferes with LAI compliance.
\end{abstract}

KEYWORDS: Access to Information Act. Information Organization. State Company. Public Transparency. Correios. 


\section{LISTA DE FIGURAS}

Figura 1 - Correspondência Brasileira Censurada 1 a Guerra Mundial ....................................54

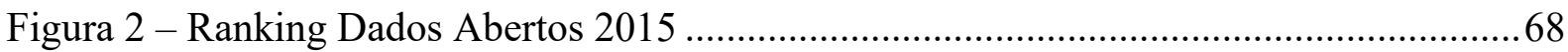

Figura 3 - Linha do tempo das ações de Transparência Pública.............................................. 73

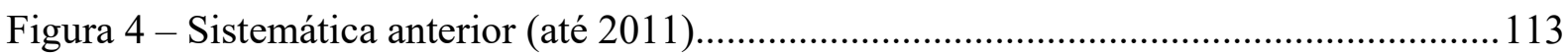

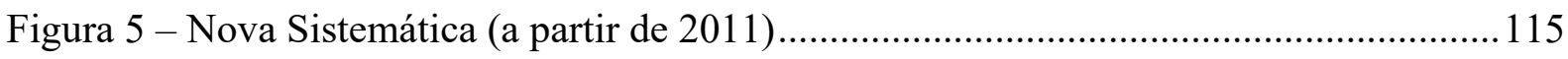

Figura 6 - Organograma Parcial da VIPAD (março/2012 a julho/2015) .............................. 116

Figura 7 - Fluxo de Decisão do SIC Correios (julho/2015)................................................ 130

Figura 8 - Origem dos Dados Coletados da Pesquisa ........................................................... 148 


\section{LISTA DE GRÁFICOS}

Gráfico 1 - Evolução do Pedidos de Prorrogação - Demais órgãos X ECT (2012/2015) .......78

Gráfico 2 - Principais motivos: Recurso $1^{\text {a }}$ Instância / ECT (2012/2015) .............................. 79

Gráfico 3 - Pedidos de Informação por Tipo de Resposta ECT (2012/2015)...................... 1333

Gráfico 4 - Evolução do Tempo Médio de Resposta (Todos X ECT) ................................. 1344

Gráfico 5 - Quadro Geral de Recursos por Instância na ECT (2012/2015)......................... 1355

Gráfico 6 - Perfil do Solicitante ECT: Tipo de Pessoa (2012/2015) ..................................... 151

Gráfico 7 - Evolução dos Pedidos de Informação e-SIC/ECT ............................................. 151

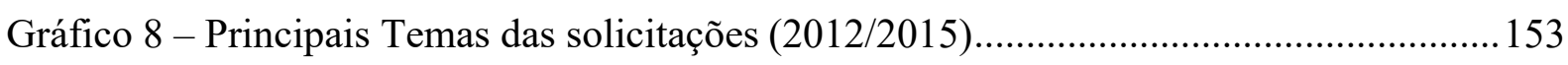

Gráfico 9 - Razões para a Negativa de Acesso a Informação (2012/2015) ......................... 1544

Gráfico 10 - Principais Motivos para Recurso (2012/2015) ................................................ 155

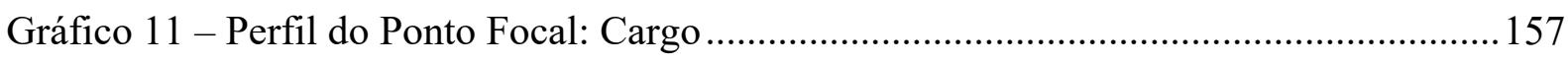

Gráfico 12 - Perfil do Ponto Focal: Período de Ingresso ..................................................... 158

Gráfico 13 - Perfil do Ponto Focal: Função ocupada........................................................... 158

Gráfico 14 - Perfil do Ponto Focal: Formação..................................................................... 159

Gráfico 15 - Perfil do Ponto Focal: Ano de Nascimento ........................................................ 159

Gráfico 16 - Perfil do Ponto Focal: Área de Lotação ........................................................... 160

Gráfico 17 - Perfil do Ponto Focal: Período de atuação ...................................................... 161

Gráfico 18 - Perfil do Ponto Focal: Atividade no SIC ......................................................... 162

Gráfico 19 - Perfil do Ponto Focal: Ramo de atividade do PF ............................................ 162

Gráfico 20 - Pesquisa de Satisfação SIC/ECT: respostas dos solicitantes (2012/2015)........ 176 


\section{LISTA DE QUADROS}

Quadro 1 - Correlação das Perguntas na Pesquisa de Satisfação .......................................... 344

Quadro 2 - Histórico do Serviço Postal no Brasil $(1500$ - 2016) ........................................... 80

Quadro 3 - Temas da Audiência Pública ......................................................................... 1022

Quadro 4 - "Prazos de Arquivamento" - Grupos de A à D - ECT ...................................... 1112

Quadro 5 - Diagnóstico e Soluções na Gestão Documental /ECT ..................................... 1177

Quadro 6 - Cronograma de implantação da nova sistemática na AC (2011) ...................... 1188

Quadro 7 - Cronograma de Implantação da LAI - CGU .................................................. 1244

Quadro 8 - Controle de Informações na Página Acesso à Informação ................................. 125 


\section{LISTA DE TABELAS}

Tabela 1 - Quantidade de Empregados e Rede de Atendimento da ECT (2016) ....................23

Tabela 2 - Evolução dos Pedidos de Informação (2012 a 2015) ............................................ 77

Tabela 3 - Controle das Ações - DEST/MPOG, em 2/05/2012 …........................................ 127

Tabela 4 - Controle Página da LAI - DEST/MPOG, em 2/05/2012 …............................... 128

Tabela 5 - Órgãos Públicos mais demandados pela LAI (2012) ......................................... 132

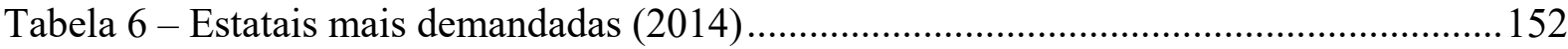

Tabela 7 - Percepção dos PF: Tempo de disponibilização da informação ............................ 163

Tabela 8 - Percepção dos PF: Conteúdo da informação ........................................................ 164

Tabela 9 - Percepção dos PF: Forma em que está disponibilizada a informação .................. 164

Tabela 10 - Percepção dos PF: Localização da informação .................................................. 166

Tabela 11 - Percepção dos PF: Gestão documental ............................................................. 167

Tabela 12 - Percepção dos PF: Mudanças trazidas com a LAI............................................ 169

Tabela 13 - Percepção dos PF: Política de Transparência Pública na área que trabalha ....... 170

Tabela 14 - Percepção dos PF: Disponibilização da informação.......................................... 172

Tabela 15 - Pesquisa de Satisfação SIC/ECT: Tipo de Resposta Recebida ........................... 177

Tabela 16 - Pesquisa de Satisfação SIC/ECT: Cumprimento de Prazos ............................... 178

Tabela 17 - Pesquisa de Satisfação SIC/ECT: ACESSO CONCEDIDO …...........................178

Tabela 18 - Pesquisa de Satisfação SIC/ECT: Comentários ACESSO CONCEDIDO ......... 179

Tabela 19 - Pesquisa de Satisfação SIC/ECT: DEMAIS OPÇÕES ….................................. 180

Tabela 20 - Pesquisa de Satisfação SIC/ECT: Comentários DEMAIS OPÇÕES .................. 181 


\section{LISTA DE ABREVIATURAS E SIGLAS}

ABRAJI - Associação Brasileira de Jornalismo Investigativo

AC - Administração Central

ACT - Acordo Coletivo de Trabalho

AI - 1 - Ato Institucional $n^{\circ} 1$

AI - 4 - Ato Institucional $n^{\circ} 4$

AI - 5 - Ato Institucional $n^{\circ} 5$

ADPF46 - Arguição de Descumprimento de Preceito Fundamental 46

ASIS - American Society for Information Science

CAD - Coordenação Administrativa

CAPES - Coordenação de Aperfeiçoamento de Pessoal de Nível Superior

CEP - Código de Endereçamento Postal

CF - Constituição Federal de 1988

CGT - Central Geral dos Trabalhadores

CGU - Controladoria Geral da União

CI - Ciência da Informação

CIEx - Centro de Informações do Exército

CIM - Centro de Informações da Marinha

CLT - Consolidação das Leis do Trabalho

CPAD - Comissão Nacional Permanente de Avaliação de Documentos

CPMI - Comissão Parlamentar Mista de Inquérito

CMRI - Comissão Mista de Reavaliação de Informações

$\mathrm{CN}$ - Congresso Nacional

CONARQ - Conselho Nacional de Arquivologia

CONSOCIAL - Conferência Nacional sobre Transparência e Controle Social

CT - Carta

CTASP Comissão de Trabalho, de Administração e Serviço Público

CUT - Central Única dos Trabalhadores

DBTA - Dicionário Brasileiro de Terminologia Arquivística

DCT - Departamento de Correios e Telégrafos

DEGSS - Departamento de Gestão da Cadeia de Suprimentos e Serviços

DERIN - Departamento de Relações Institucionais

DEST - Departamento de Coordenação e Governança das Empresas Estatais

DL200 - Decreto-Lei 200

DL509 - Decreto-Lei 509

DOIEx - Departamento de Operações e Informações do Exército

DOPS - Departamento de Ordem Política e Social

DOU - Diário Oficial da União

DR-PR - Diretoria Regional do Paraná

DRs - Diretorias Regionais

EaD - Educação a Distância

EBC - Empresa Brasileira de Comunicações

ECT - Empresa Brasileira de Correios e Telégrafos

ENAP - Escola Nacional de Administração Pública

e-SIC - sistema eletrônico do Serviço de Informação ao Cidadão

FID - Federação Internacional de Documentação

GCSI - Gerencia Corporativa de Segurança da Informação

GDC - Gestão de Documentos Correntes 
GDOC/CESER - Gerência de Documentação/Central de Serviços

GDOC/DEGSS - Gerência dos Processos de Gestão Documental

GSIC - Gerência de Segurança da Informação

IBICT - Instituto Brasileiro de Informação em Ciência e Tecnologia

IBGC - Instituto Brasileiro de Governança Corporativa

IES - Instituições de Ensino Superior

IIB - Instituto Internacional de Bibliografia

LAI - Lei de Acesso à Informação

LC101 - Lei Complementar $n^{\circ} 101$

LC103 - Lei Complementar $n^{\circ} 103$

MANCOM - Manual de Comunicação

MANPES - Manual de Pessoal

MANTIC - Manual de Tecnologia da Informação e Comunicação

MC - Ministério das Comunicações

MG - Minas Gerais

MP - Medida Provisória

MPF - Ministério Público Federal

MPOG - Ministério do Planejamento, Orçamento e Gestão

NDA - Núcleo de Documentação e Arquívos

NUP - Número Único de Protocolo

OCDE - Organização para a Cooperação e Desenvolvimento Econômico

OGU - Ouvidoria Geral da União

OKBR - Open Knowledge Brasil

OKI - Open Knowledge Internacional

ONG - Organização Não Governamental

ONU - Organização das Nações Unidas

OSC - Organização da Sociedade Civil

OTT - Operador de Triagem e Transbordo

OUVID - Ouvidoria

PASTE - Programa de Recuperação e Ampliação do Sistema de Telecomunicações e do

Sistema Postal

PDT - Partido Democrático Trabalhista

PF - Ponto Focal do SIC

PL - Projeto de Lei

PMDB - Partido do Movimento Democrático Brasileiro

PNPS - Programa Nacional de Participação Social

PrND - Programa Nacional de Desburocratização

PT - Partido dos Trabalhadores

PTB - Partido Trabalhista Brasileiro

PRESI - Presidência dos Correios

RJ - Rio de Janeiro

RJU - Regime Jurídico Único

RPN - Rede Postal Noturna

S.A. - Sociedade Anônima

SAG - Sistema de Acompanhamento Gerencial

SEAD - Seção Administrativa

SEI - Sistema Eletrônico de Informações

SD - Partido Solidariedade

SFT - Supremo Tribunal Federal

SIAPE - Sistema Integrado de Administração de Recursos Humanos 
SIC - Serviço de Informações ao Cidadão

SISG - Sistema de Serviços Gerais

SNI - Serviço Nacional de Informação

SNPS - Sistema Nacional de Participação Social

SP - São Paulo

TAC - Termo de Ajuste e Conduta

TCU - Tribunal de Contas da União

TST - tribunal Superior do Trabalho

UFMG - Universidade Federal de Minas Gerais

UFRJ - Universidade Federal do Rio de Janeiro

UnB - Universidade de Brasília

UNESCO - Organização das Nações Unidas para a Educação, a Ciência e a Cultura

UNICORREIO - Universidade Corporativa dos Correios

USP - Universidade de São Paulo

VICOP - Vice-Presidência de Clientes e Operações

VICOR - Vice-Presidência Corporativa

VIENC - Vice-Presidência de Encomendas

VIFIC - Vice-Presidência de Finanças e Controle

VIGEP - Vice-Presidência de Gestão de Pessoas

VIPAD - Vice-Presidência de Administração

VIPOS - Vice-Presidência de Negócios Postais

VITEC - Vice-Presidência de Tecnologia e Infraestrutura

VISER - Vice-Presidência de Serviços 


\section{SUMÁRIO}

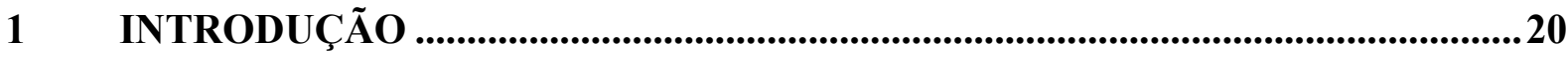

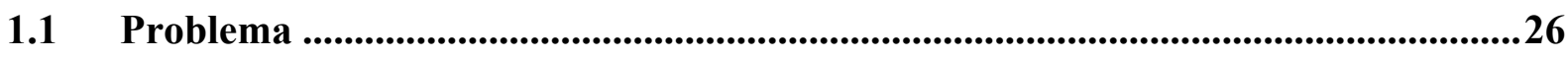

1.2 Objetivos geral e específicos .......................................................................................27

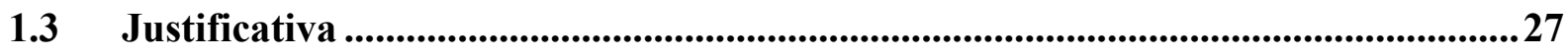

1.4 Metodologia....................................................................................................................31

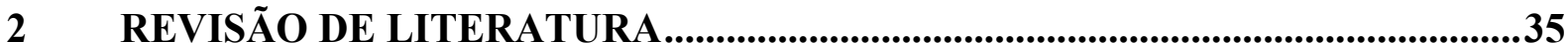

2.1 O Estado Brasileiro e as Estatais ................................................................36

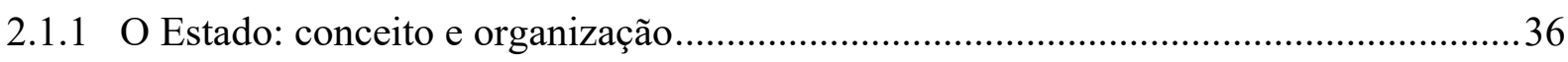

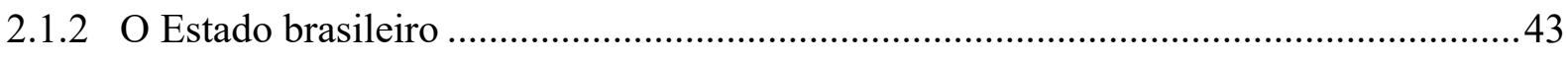

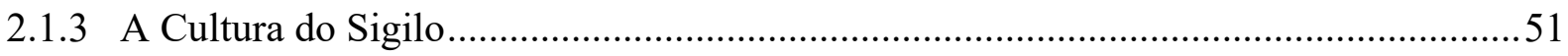

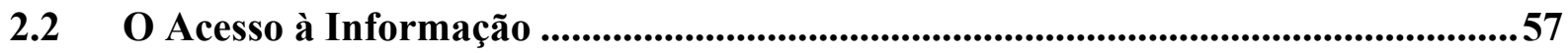

2.2.1 A Ciência da Informação e o Compromisso Social.......................................................57

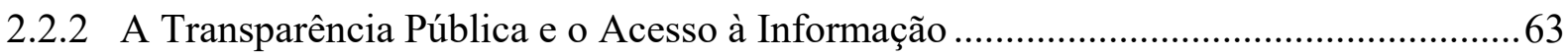

2.2.3 A Lei de Acesso à Informação no Brasil................................................................... 74

2.3 Os Correios: Empresa Pública S.A.................................................................................79

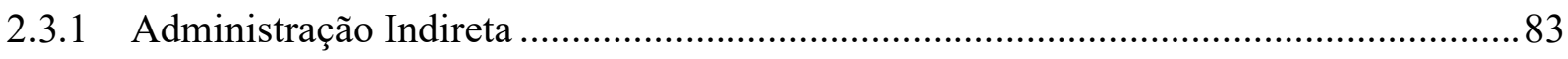

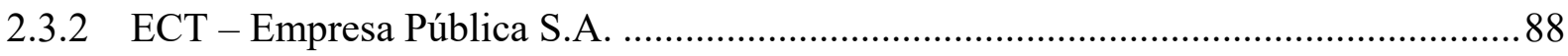

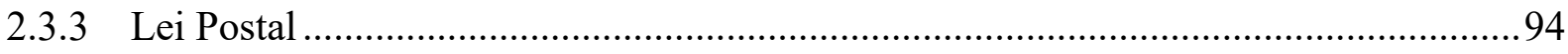

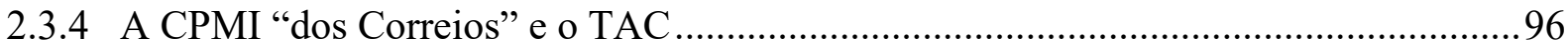

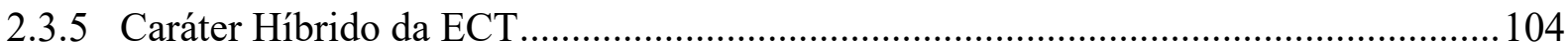

3 A ORGANIZAÇÃO DA INFORMAÇÃO NA ECT ...........................................108

3.1 A Gestão Documental antes de 2011 ...................................................................108

3.2 A Nova Sistemática de Gestão Documental a partir de 2011 ..............................114

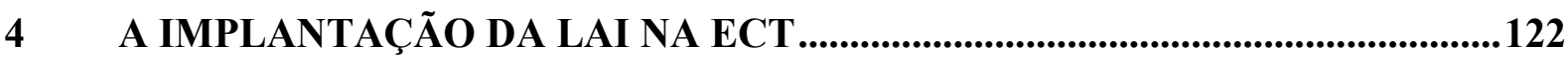

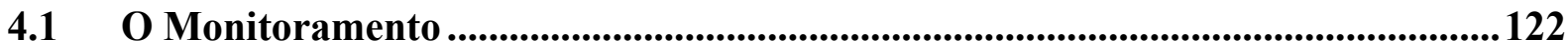

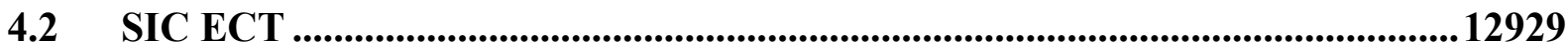

4.3 Os casos: CEP e os 100 maiores salários da DR-PR.............................................136

4.4 A Cultura Organizacional da ECT e a implantação da LAI ...............................142

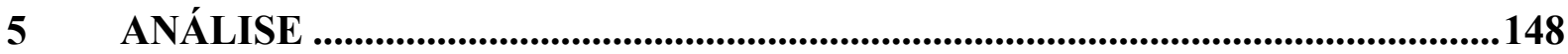

5.1 Recursos: CEP e Salários........................................................................................149

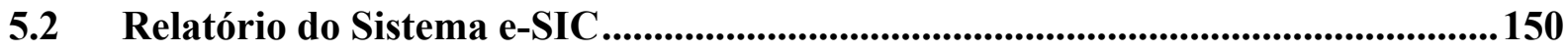

5.3 Questionário aplicado aos Pontos Focais .....................................................................155 
5.4 Relatório de Avaliação da Integridade da ECT.................................................172

5.5 Relatório da Pesquisa de Satisfação........................................................................172

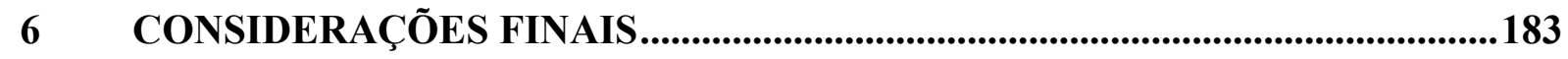

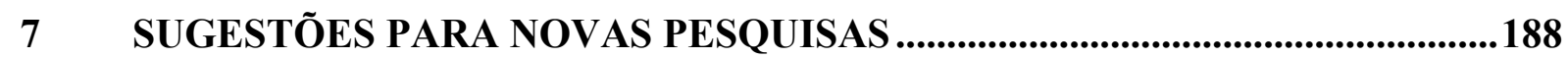

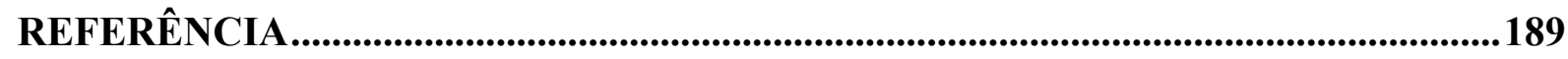

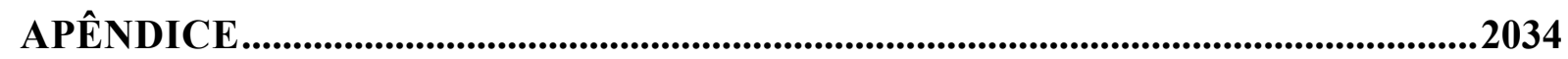

Apêndice A - Questionário Pré-teste................................................................................2034

Apêndice B - Questionário aplicado nos Pontos Focais do SIC-ECT ..........................2055

Apêndice C - Resposta do Questionário ......................................................................................22234

Apêndice D - Relatório da Pesquisa de Satisfação .........................................................2402

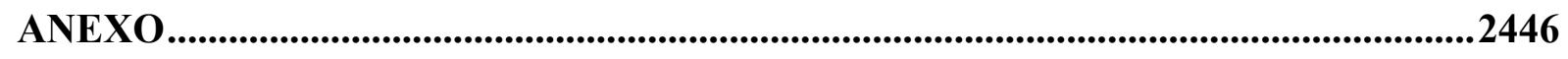

Anexo I - Termo de Ajustamento de Conduta (TAC) ...................................................2446

Anexo II - Relatório da VIPAD - 009/2011, de 15/08/2011 ............................................255

Anexo III - Pedido de Informação sobre o Mensalão - NUP 99923001883201434 ........259

Anexo IV - Manual de Comunicação, Módulo 7, Capítulo 3 ..............................................262

Anexo V - Apresentação do DEST, dia 2 de maio de 2012 ..................................................269

Anexo VI - Apresentação do Ministério das Comunicações, dia 3 de maio de 2012 .....274 


\section{INTRODUÇÃO}

O Brasil tem se esforçado na implementação dessas medidas, porque acredita no regime democrático, no regime participativo e porque entende que o esforço pelo desenvolvimento econômico e social exige, como complemento indispensável, uma gestão qualificada do poder público, uma atenção permanente à lisura e à correção no uso dos recursos públicos e a eficácia em sua aplicação.

Presidenta Dilma Rousseff ${ }^{1}$

No dia 18 de novembro de 2011, a Presidenta Dilma Rousseff sancionou a Lei 12.527 que regula o acesso às informações como previsto no inciso XXXIII do art. $5^{\circ}$, no inciso II do $\S 3^{\circ}$ do art. 37 e no $\S 2^{\circ}$ do art. 216 da Constituição Federal. Após mais de duas décadas, a aprovação da Lei de Acesso à Informação (LAI) é considerado um passo relevante no caminho da consolidação da democracia no Brasil, ampliando a participação cidadã e fortalecendo os instrumentos de controle da gestão pública. O livre fluxo de informações e das ideias é crucial para o pleno exercício da democracia, efetivando o direito ao saber, ao conhecimento e à verdade, base para o efetivo respeito aos direitos humanos.

O livre fluxo de informações e ideias ocupa justamente o cerne da noção de democracia e é crucial para o efetivo respeito aos direitos humanos. Se o direito a liberdade de expressão - que compreende o direito de buscar, receber e transmitir informações e ideias - não é respeitado, não é possível exercer o direito ao voto, além das violações de direitos humanos ocorrerem em segredo, e de não haver como denunciar a corrupção e a ineficiência dos governos. É fundamental, para a garantia do livre fluxo das informações e das ideias, o princípio de que os órgãos públicos detenham informações não para eles próprios, mas em nome do povo. (MENDEL, 2009, p.1)

A implantação da LAI no Brasil, abrangeu todos os poderes da República (executivo, legislativo e judiciário) e todos os três níveis de governo (federal, estadual e municipal). Iniciou sua implantação no poder executivo federal com a utilização de uma ferramenta tecnológica, através de um sistema de âmbito nacional, monitorado pela Controladoria Geral da União $(\mathrm{CGU})^{2}$. O sistema e-SIC implantado em maio de 2012, e oficializado em 2015 através da

\footnotetext{
${ }^{1}$ Discurso da Presidenta da República, Dilma Rousseff, na abertura da $1^{\text {a }}$ Conferência de Alto Nível de Parceria para Governo Aberto (OGP).

${ }^{2}$ A Presidenta Dilma foi afastada do cargo dia 12/05/2016 e neste mesmo dia o Vice-Presidente Michel Temer ao assumir temporariamente, por 180 dias, publicou a Medida Provisória 176, que extinguiu a CGU e criou o Ministério da Transparência, Fiscalização e Controle. O impedimento definitivo ocorreu em 31/08/2016 e a MP convertida em Lei $\mathrm{n}^{\mathbf{0}}$ 13.341. Entretanto, optamos por continuar a utilizar, em toda a pesquisa, a sigla CGU como referência ao órgão de controle.
} 
Portaria Interministerial $\mathrm{n}^{0} 1.254^{3}$, é o sistema centralizado para tratamento de pedidos de acesso à informação no âmbito do Poder Executivo Federal, onde o cidadão acompanha sua tramitação e respostas. A CGU lançou uma cartilha em 2011 onde indicava os desafios para a Administração Pública.

O desafio, agora, é assegurar a implementação desta Lei. Devemos enfrentar desafios de natureza técnica e tecnológica e também de caráter administrativo, que incluem a necessidade de recursos financeiros e humanos - estes, devidamente capacitados - para garantir a observância do que dispõe a Lei. Além disso, teremos que vencer a cultura do sigilo que, de forma silenciosa e invisível, ainda se constitui um dos grandes obstáculos para a abertura dos governos. (CGU, 2011, p.6).

A implantação da lei nas empresas estatais, estruturas da administração pública indireta, apresenta um diferencial com relação aos demais órgãos do poder executivo federal. Estas empresas têm um regime jurídico diferenciado, são instituições públicas, mas regidas pelo direito privado. Como empresas estatais, estão sujeitas aos controles públicos e comprometidas com objetivos coletivos, podendo ser prestadoras de serviços públicos ou exploradoras de atividades econômicas.

O Supremo Tribunal Federal (STF), nos debates a que tem sido chamado a se manifestar sobre as empresas estatais que prestam serviços públicos, as caracterizam como empresas submetidas a um regime híbrido.

Embora a rigor, as denominadas 'empresas estatais' ostentem a natureza jurídica de direito privado, elas se submetem a regime híbrido, ou seja, sujeitam-se a um conjunto de limitações que têm por escopo a realização do interesse público. Em outras palavras, no caso dessas entidades, ocorre uma derrogação parcial das normas de direito privado em favor de certas regras de direito público. (BRASIL - STF, 2013, p. 42)

Para compreendermos a organização e o acesso à informação após promulgação da Lei de Acesso à Informação nos Correios $^{4}$, e as dificuldades em atender às solicitações de informações registradas pelos cidadãos, iremos analisar a estrutura do Estado brasileiro, em especial a administração indireta, no período de criação da empresa ECT e no período de

\footnotetext{
${ }^{3}$ Portaria Interministerial no ${ }^{\circ}$.254, 18 de maio de 2015, publicada no Diário Oficial da União de 19/05/2015, institui o sistema e-SIC no âmbito do Poder Executivo Federal.

${ }^{4}$ No desenvolver desta pesquisa usaremos os termos "ECT" e "Correios" para identificar a Empresa Brasileira de Correios e Telégrafos, que já adotou a sigla EBCT, depois ECT e, desde 2014 vem utilizando a marca Correios.
} 
implantação da LAI; a organização da informação na empresa e como essa organização trouxe, e ainda traz, implicações no cumprimento da lei.

Identificaremos na administração indireta, na sua estrutura, assim como, no seu respectivo corpo administrativo e técnico, os dilemas de atuação como órgão público na prestação de serviço público e nas atividades concorrenciais, e como consequência, os conflitos frente ao controle social. Não coincidentemente, são as empresas estatais (Correios, Petrobrás) que surgem nas manchetes dos jornais após ações de auditoria dos órgãos de controle, como Tribunal de Contas da União (TCU) e Controladoria Geral da União (CGU), com ocorrências de práticas administrativas que se confrontam com a legislação vigente para uso dos recursos públicos. Para os fiscais, mídias e sociedade em geral, tudo indica corrupção, desvio de recursos públicos. Mas será que tudo é desvio do uso de recursos públicos?

A partir da Constituição Federal de 1988 (CF) a gestão arquivística é fortalecida no país, através do $\S 2^{\circ}$ do art. 216. Sua regulamentação em 1991, através da Lei nº 8.159 - Lei de Arquivos, contou com forte participação do Arquivo Nacional (FONSECA, 2013, p.69) e foi um grande avanço para a gestão documental no país. Entretanto, até que ponto a autonomia inserida no Decreto-Lei 200/1967, e mantida no conjunto de arcabouço legislativo e normatizador, desde a ditadura militar, não permitiu essa independência e maior alinhamento ao mercado, não internalizando instrumentos de gestão pública do Estado democrático? Como dar acesso às informações da empresa pública se a mesma é caracterizada como híbrida, presta serviço público e explora atividade econômica em nome do Estado no mercado concorrencial, que neste considera suas informações protegidas pelo sigilo comercial?

Desde 2011, através de cessão prevista no Regime Jurídico Único (RJU), estive em exercício na ECT. Primeiramente, recebi a incumbência de coordenar o Grupo de Trabalho que buscasse uma solução para o atendimento à determinação da Cláusula $2^{\mathrm{a}}$ do Termo de Ajuste e Conduta (TAC) do Ministério Público Federal (MPF) do Inquérito Civil $\mathrm{n}^{\circ}$ 1.16.000.000919/2005-09 (ANEXO I). A referida cláusula tratava de autuar, instruir, tramitar e arquivar processos de contratação na empresa e o inquérito civil estava relacionado às investigações do que ficou conhecido como "Mensalão dos Correios". Depois, em fevereiro de 2012, fui designada para o Grupo de Trabalho de Implantação da Lei de Acesso à Informação onde assumi, posteriormente, a função de suplente da Autoridade de Monitoramento da LAI na empresa e de Gestora do Serviço de Informação ao Cidadão (SIC). A atuação nestes espaços me possibilitou identificar as dicotomias existentes na ECT: a cultura organizacional, ainda marcada pelo alto grau de hierarquização, a exemplo da estrutura militar (tramitação avulsa de documentos, existência de manuais, leitura semanal da Primeira Hora, sigilo de informações, 
etc.) e as situações ambíguas por parte do corpo de empregados da empresa, ora usando argumentos em defesa da empresa pública, ora como empresa voltada para o mercado, como as empresas privadas. Outra razão muito importante, foi a verificação do acúmulo de informações/documentos produzidos na empresa, pelo seu porte e abrangência nacional. Uma empresa que tem o monopólio da correspondência, ou seja, do transporte de documentos em meio físico no Brasil. Os Correios são a maior empregadora pelo regime CLT ${ }^{5}$ do Brasil e está presente em praticamente todos os municípios do país.

Tabela 1 - Quantidade de Empregados e Rede de Atendimento da ECT (2016)

\begin{tabular}{|l|r|c|}
\hline \multicolumn{2}{|c|}{ Empregados Celetistas } \\
\hline \multicolumn{1}{|c|}{ Cargo } & Quantidade & \multicolumn{1}{c|}{$\%$} \\
\hline Atendente Comercial & 26.318 & $22,42 \%$ \\
\hline Carteiro & 59.718 & $50,86 \%$ \\
\hline $\begin{array}{l}\text { Operador de Triagem e } \\
\text { Transbordo }\end{array}$ & 13.738 & $11,70 \%$ \\
\hline Outros cargos & 17.631 & $15,02 \%$ \\
\hline Total & A GÊNCIAS ECT \\
\hline \multicolumn{2}{|c|}{ Tipo } & Quantidade \\
\hline
\end{tabular}

Fonte: elaborado pela autora com base nos dados na página da internet.

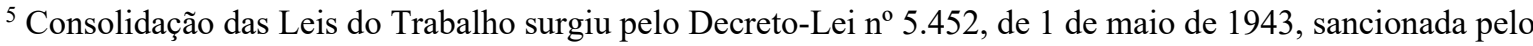
então presidente Getúlio Vargas, unificando toda legislação trabalhista existente no Brasil, rege as relações de trabalho na iniciativa privada e entidades públicas de direito privado.
} 
Dentre as mudanças introduzidas no regime militar, a criação do Ministério das Comunicações efetivou no Brasil o que já era uma realidade: a separação da informação dos transportes. Antes da invenção do telégrafo ${ }^{6}$ para transportar uma informação era necessário também transportar o meio de comunicação (o impresso, manuscritos etc.). O telégrafo permitiu que a mensagem viajasse sem a dependência dos mensageiros e dos transportes (animais, carroças, viaturas, navios, trens, aviões). Assim, um departamento da estrutura executiva de governo, o DCT, com funções operacionais, se transforma em uma empresa pública de direito privado com funções estratégicas no controle da informação ${ }^{7}$.

A manutenção do serviço postal e do correio aéreo nacional estão presentes no Art. 21, inciso X, da Constituição Federal, e nos termos do artigo $9^{\circ}$, inciso I, da Lei no $6.538 / 78$, está estabelecido que o serviço postal é explorado pela União em regime de monopólio e é outorgado à ECT a execução de tais serviços. O Decreto-Lei 509, de 20 de março de 1969, que transforma o DCT em ECT, enfatiza o caráter empresarial mudando sua vinculação ao Estado (TEIXEIRA, 2013, p.33). Em 2011, a Lei n n $^{\text {12.490, de }} 16$ de setembro de 2011, no art. 11, introduz aos serviços postais as atividades de logística, serviços financeiros e eletrônicos e aplica, subsidiariamente, a Lei $\mathrm{n}^{\mathrm{o}}$ 6.404, de 15 de dezembro de 1974 que dispõe sobre as Sociedades por Ações. Em 2016, a Lei n 13.303, de 30 de junho, que dispõe sobre estatuto jurídico para as empresas públicas, estabelece a necessidade regras de governança corporativa, de transparência e de estruturas, práticas de gestão de riscos e de controle interno, entre outros.

Identificamos a Ciência da Informação como uma ciência que reflete sobre como deve ser sua interação com a sociedade e, como consequência, seu compromisso social, ao se dedicar ao estudo do ciclo de vida da informação - produção, manuseio, armazenamento, transporte e descarte - para que sua recuperação seja possível para a concretização do acesso à informação pelo cidadão. Neste sentido, o Estado brasileiro, sua organização e a política de organização da informação, em especial a gestão documental nas instituições públicas são elementos fundantes para atender às demandas da sociedade contemporânea por transparência pública, assegurando o efetivo exercício da cidadania e acesso rápido aos documentos e informações gerados pelo órgão e assim, fazem parte de nosso referencial teórico de estudo para o projeto.

\footnotetext{
${ }^{6} \mathrm{O}$ telégrafo é um aparelho para comunicação que utiliza eletricidade para enviar mensagens codificadas através de fios. Segundo a Escola Britannica, os dois primeiros a entrar em operação foram inventados por volta de 1830, na Grã-Bretanha e EUA.

${ }^{7}$ O Departamento de Correios e Telégrafos (DCT) foi criado no Governo de Getúlio Vargas e era vinculado ao Ministério de Viação e Obras Públicas, pelo Decreto-Lei 200/1967 passa a ser vinculada ao Ministério das Comunicações. O Decreto-Lei 509/1969, como veremos, atribui a ECT o monopólio do serviço postal, telégrafos e de telecomunicações para o Sistema Nacional de Telecomunicações (Art. 15 e 16 do DL509).
} 
Um outro aspecto a destacar, é a cultura do segredo presente na empresa pública. Até a implantação da LAI a maioria dos empregados desconhecia a tabela de funções de confiança em vigor e, apesar da existência da rede interna - intranet, muitas informações eram restritas à alguns empregados ocupantes dos altos escalões. A empresa adota procedimento similar ao dos quartéis, e toda terça-feira há a leitura em voz alta do "Primeira Hora"8 por parte do chefe do setor que aglutina seus subordinados e lê para eles as principais notícias.

A ECT não publica todas as suas portarias e normativos no Diário Oficial da União (DOU) - exceção às relativas a contratações, e não possui um boletim interno que reúna todas as publicações de Portarias, Relatórios e Decisões. Com cerca de $60 \%$ de seu corpo funcional atuando fora de uma estação de trabalho, sem acesso a computador e intranet corporativa, e em um mundo cada vez mais informatizado, a não circulação de informações pela web é um dificultador nas comunicações internas. Nesse sentido, havia um grande temor de que os próprios empregados da empresa fossem os principais usuários da LAI, em busca de informações sobre eles e da própria empresa.

Após a implantação da LAI em 2012, as atas dos colegiados passaram a estar disponível na página da empresa conforme orientação da CGU na implantação da lei, assim como, várias informações, antes desconhecidas dos próprios empregados e do conjunto da sociedade brasileira. O levantamento destas informações para compor a página de Transparência da ECT foi o maior desafio nesse processo, e confirmam Araújo Junior, Sousa e Albuquerque (2015, p.45) “o maior entrave ao pleno acesso à informação não são as poucas restrições impostas pela Lei, mas a condição de organização da informação pública".

No início deste projeto de pesquisa foram poucos os trabalhos que encontramos que abordavam a implantação da LAI nas empresas estatais. A publicação de trabalhos que tratam deste tema nos órgãos públicos de direito privado, como as empresas públicas federais, é uma lacuna nesta experiência de governança e de instrumentos de controle social sobre o Estado. A ECT, pela sua importância na política de informação e de comunicação no Brasil e sua recém trajetória, pode contribuir para o controle social das empresas estatais, na sua sustentabilidade e estimular uma maior transparência e democratização das empresas públicas brasileiras. Os avanços conquistados nestas últimas décadas de transparência pública não podem retroceder.

\footnotetext{
${ }^{8}$ Informativo elaborado pela Diretoria Executiva que é recebido por email pelos empregados. Como a maioria é da área operacional (carteiros e operadores de triagem e transbordo), o chefe lê o texto em voz alta às terçasfeiras. Esta rotina também é executada nas áreas administrativas, mas com menos frequência. O "Primeira Hora" se assemelha a prática nos quartéis da "Ordem do Dia" em que os soldados devem ficar alinhados ouvindo.
} 
A dissertação está estruturada da seguinte forma: no primeiro capítulo estão a contextualização e a visão geral da pesquisa, a definição dos problemas, o objetivo geral, os específicos, a justificativa e a metodologia.

O capítulo seguinte contempla a revisão de literatura, assinalando textos e autores que nos auxiliaram no desenvolvimento dos temas abordados sobre o Estado, o Estado Brasileiro e as Estatais, Os Correios, tratando desde da criação da empresa e debate atual, e o Acesso à Informação. A partir do arcabouço teórico da Ciência da Informação (CI) será analisada o Acesso à Informação e a política de Transparência Pública.

O capítulo três trata da Organização da Informação na ECT com uma descrição e análise da gestão documental antes de 2011 e depois da nova sistemática adotada na empresa a partir de setembro de 2011. As ações decorrentes do TAC; a adoção do Número Único de Protocolo (NUP) e da adaptação do sistema de Gestão de Documentos Correntes (GDC) para a formação de processos administrativos.

O capítulo quatro aborda a Implantação da LAI nos Correios. Inicialmente, será apresentado um relato do processo de monitoramento da Controladoria Geral da União (CGU), do Departamento de Coordenação e Governança das Empresas Estatais (DEST) e do Ministério das Comunicações (MC); a instalação do GT de implantação da LAI, do SIC e todos os procedimentos adotados para garantia dos prazos legais e discutiremos dois casos que o caráter hibrido da empresa impacta no acesso à informação pública.

O capítulo cinco apresenta uma análise dos dados levantados, qualitativos e quantitativos, quanto aos pedidos e recursos registrados no e-SIC-ECT; dados da "Pesquisa de Satisfação" respondida pelos cidadãos; avaliação da CGU no "Relatório de Integridade" da ECT, no item Transparência da pessoa jurídica e do Questionário aplicado aos empregados da empresa responsáveis em providenciar o atendimento aos pedidos de informação ao cidadão, chamados de "Pontos Focais do SIC".

O capitulo seis trata das considerações finais e apresentação dos resultados alcançados.

\subsection{Problema}

Diante do regime jurídico destacado, formulamos as seguintes questões: De que maneira a condição de empresa híbrida dos Correios influi na aplicação da LAI quanto à transparência das informações? Como a cultura organizacional dos Correios influencia na organização e acesso às suas informações após a promulgação da LAI? 


\subsection{Objetivos geral e específicos}

O objetivo geral da pesquisa é compreender como a cultura organizacional e o estatuto jurídico da ECT influenciam na organização da informação e na aplicação da LAI na empresa.

O objetivo geral desdobrar-se-á nos seguintes objetivos específicos:

a) contextualizar o momento histórico e político no Brasil em que é criada a empresa estatal Empresa Brasileira de Correios e Telégrafos;

b) identificar o processo de redemocratização do Estado brasileiro;

c) traçar um histórico da gestão documental na Administração Pública e a cultura de Transparência Pública;

d) identificar os processos de organização da informação na ECT antes e depois da LAI.

\subsection{Justificativa}

Durante mais de trinta anos, a vida profissional desta autora foi dedicada a três áreas do conhecimento: a matemática, a educação e a gestão pública. A paixão pela matemática foi o caminho para chegar a graduação na UFRJ e lá encontrar Paulo Freire e assim, a educação passar a ser a área dominante. No ambiente acadêmico, veio a literatura marxista, a dialética, indissociabilidade do ensino, pesquisa e extensão como métodos para a produção científica. A formação cartesiana e marxista, moldaram uma profissional com uma especificidade: a organização.

Em 1990, atuando na gestão pública, a chefia da Seção de Dados Acadêmicos do Sistema de Acompanhamento Gerencial (SAG) da UFRJ, foi uma importante experiência de organização das informações acadêmicas e científicas, em meio eletrônico. Todos os formulários de produção científica, teses e dissertações, publicações, projetos de pesquisas, projetos de extensão e atividades de ensino da UFRJ eram digitadas para o sistema SAG, produzindo um banco de dados que permitia a gestão acadêmica da universidade e emissão de relatórios para a CAPES. Inúmeras outras experiências profissionais trouxeram grandes 
desafios na importante tarefa de pensar na geração, no uso, no armazenamento, na tramitação/transporte, na recuperação e no descarte da informação.

A ida, em 2011, para a ECT concretizou-se como uma experiência muito diferente. O convite envolvia um caráter político, uma vez que assumia a presidência da empresa uma indicação do Partido dos Trabalhadores $(\mathrm{PT})^{9}$, com a eleição da primeira mulher na presidência da república, Dilma Rousseff. Um desafio político, que esta autora assumiu, pela primeira vez e com muito orgulho, com responsabilidade política para desempenhar os conhecimentos técnicos acumulados. Um desafio profisssional, uma vez que as atividades do serviço postal não eram de conhecimento público, pela baixa concorrência e inexistência de modelos a serem comparados. Um desafio pessoal, pelo afastamento da família e do Rio de Janeiro, para morar em Brasília. Na bagagem levava a experiência na gestão no sistema universitário federal e a experiência fora do país.

A ECT é uma empresa muito importante para o Brasil, ela traz na sua história os 350 anos de serviço postal brasileiro, mas como empresa pública ainda não chegou aos 40 . Entretanto, ao chegar encontramos uma estrutura burocrática, como é a marca do Estado brasileiro, com um sistema altamente hierarquizado, regras e procedimentos padrões, de domínio restrito, ambiente de silêncio, uma dinâmica administrativa atrasada tecnologicamente e distante das práticas da gestão pública. O ambiente universitário nos apresenta o método investigativo para procurar compreender o mundo, buscar informações para melhor compreendê-lo e construir conhecimento. Usando o método da observação direta, lendo os manuais da empresa, documentos, e na execução de tarefas que estiveram sob nossa responsabilidade, começamos a compreender um pouco mais desta empresa.

$\mathrm{O}$ Termo de Ajuste de Conduta $(\mathrm{TAC})^{10}$ relativo ao Inquérito Civil $\mathrm{n}^{\mathrm{o}}$ 1.16.000.000919/2005-09 é um dos documentos que possibilita analisar as condições da gestão da informação na empresa. O termo foi assinado pela ECT e o Ministério Público Federal (MPF) em 21/10/2010, e refere-se a procedimentos relacionados à fiscalização, autuação e arquivamento de processos de contratação e de gestão de contratos no contexto da Lei de Licitação, Lei no 8.666/93, e da Lei do Processo Administrativo, Lei no 9.784/99. A cláusula

\footnotetext{
${ }^{9}$ O Presidente Luís Inácio Lula da Silva foi eleito pelo Partido dos Trabalhadores (PT) e governou o país de 2003 a 2010, durante os oito anos de governo Lula o Ministério das Comunicações esteve sob a gestão de partidos aliados (Miro Teixeira - PDT; Eunício Oliveira, Hélio Costa e José Artur Filardi - PMDB).

${ }^{10} \mathrm{O}$ TAC referia-se a matéria jornalística publicada pela Revista Veja, edição n ${ }^{\circ} 1.905$ - ano 38, de 18 de maio de 2005, sobre um esquema de corrupção na área de licitações e contratos da Empresa Brasileira de Correios e Telégrafos que veio a ser conhecido nacionalmente como "Mensalão dos Correios".
} 
segunda diz respeito à instrução, autuação e arquivamento de processos de licitação e gestão de contratos, tendo como base os artigos 38 e 60 da Lei 8.666/93 e Artigo $22 \S 4^{\circ}$ da Lei 9.784/99. Ao participar deste processo, conheci melhor a realidade da ECT.

Ao analisar os termos do TAC houve o despertar e o interesse em ler os três volumes do Relatório Final da Comissão Parlamentar Mista de Inquérito (CPMI) " "dos Correios" do Congresso Nacional. No decorrer da leitura do Relatório encontramos várias vezes destaques quanto à desorganização documental da empresa que serão citados nesta dissertação. Situação confirmada pela própria direção da empresa, no relatório que decidiu pela nova sistemática de gestão documental.

Observa-se que a ECT atualmente não trabalha integralmente sob a ótica de formação de processos, ou seja, há casos de assuntos que deveriam tramitar como "processos administrativos", mas são tratados em diversas fases como uma série de documentos não integrados, muitas vezes resultando na perda da visão completa do tema e da qualidade e/ou velocidade do processo decisório. Como exemplos desta situação podem ser citados os casos em que uma $\mathrm{CI}^{12}$ tramita de forma avulsa, fazendo referência a diversas outras CI's ou documentos, sem que tais expedientes estejam tramitando em conjunto naquela oportunidade. (BRASIL, ECT, 2011, p.14).

Entretanto, logo no volume I da CPMI, o relatório descreve o envolvimento da Agência Brasileira de Inteligência (ABIN) no item cinco intitulado "Espionagem nos Correios".

A gravação da fita de vídeo, em que o funcionário dos Correios, Maurício Marinho, é flagrado recebendo R $\$ 3.000,00$, foi resultado da chamada espionagem industrial ou comercial. No entanto, o mais importante é analisar a possível imbricação entre a espionagem industrial e a espionagem política por intermédio de um órgão do Estado, a Agência Brasileira de Inteligência (ABIN). (BRASIL, CONGRESSO NACIONAL, 2006, pag.30)

O medo expresso por vários empregados, através de denúncias de perseguição política, assédio moral e demissões imotivadas, realmente tinha uma razão de ser.

Conhecendo melhor a empresa, os problemas, a sua história, foi possível construir, em conjunto com os empregados, uma proposta de solução para atender ao TAC que teve a aprovação da Diretoria Executiva da empresa. A proposta consistiu na adoção do Número

\footnotetext{
${ }^{11}$ Uma Comissão Parlamentar Mista de Inquérito (CPMI) é composta por Senadores e Deputados Federais, quando o assunto é complexo e envolve as duas casas. Assim, foi instituída a CPMI dos "Correios" em 9 de junho de 2005 para apurar as denúncias. O Relatório Final, composto de três volumes foi aprovado dia 5 de abril de 2006 - Disponível em < http://www.senado.gov.br/atividade/Comissoes/CPI/RelatorioFinalCorreios.asp>. ${ }^{12} \mathrm{CI}$ - Comunicação Interna - tipologia documental utilizada na ECT para tudo e que foi vinculada à abertura de processo na nova sistemática documental.
} 
Único de Protocolo (NUP) e da reestruturação do sistema de Gestão de Documentos Correntes $(\mathrm{GDC})^{13}$, já existente na empresa e, assim, uma nova sistemática de Gestão Documental foi implementada na empresa. O processo de capacitação do corpo funcional na administração central e regionais, nos aproximou ainda mais dos problemas organizacionais, dos conflitos entre público e privado vivido pelos empregados em graus variados de hierarquia. A aprovação da LAI e a nossa indicação para o Grupo de Trabalho, trouxeram um outro grande desafio: o de romper a barreira de que tudo era sigiloso, para a nova era segundo a qual o sigilo é a exceção.

Inicialmente, pensou-se em tratar esta pesquisa como um estudo de caso onde estaria explorando uma atividade, ou um processo, e a ECT seria o objeto de estudo. Entretanto, ao coletar os dados qualitativos e quantitativos, após observações da banca de qualificação, percebeu-se a riqueza do material e da especificidade do estudo.

Desde a aprovação da LAI, em 2011, inúmeros artigos em jornais, artigos científicos, textos de opiniões, livros, revistas, dissertações de mestrado e teses de doutorado, sobre o tema foram escritos, publicados e compartilhados. Há muito na literatura sobre o processo de tramitação, aprovação e implantação da lei. Entretanto, são poucos os trabalhos que tratam da análise da LAI com o olhar nas empresas estatais e a partir do olhar do gestor da lei no órgão, e esta é a primeira ${ }^{14}$ que trata especificamente da lei na ECT, e analisando os vários atores envolvidos.

Pelo exposto, desenvolver essa pesquisa tem várias justificativas. Do registro da experiência vivida a trazer os aspectos teóricos e epistemológicos para discussão pública. A ECT tem uma grande importância para todos os brasileiros e brasileiras pelos serviços que ela presta e, portanto, o que acontece na empresa é de interesse público.

\footnotetext{
${ }^{13}$ O GDC foi desenvolvido na Diretoria Regional do Paraná e consistia em um sistema operacional que permitia gerar numeração aos documentos e inserir informações sobre o documento criado, mas não permitia acompanhar a tramitação do documento.

${ }^{14}$ A afirmação é fruto de constatação após ampla pesquisa na base de dados de vários repositórios institucionais das principais universidades do país, na base Scielo, e pelo fato da autora ter ocupado a função de Gestora do SIC, desde do início da vigência da LAI nos Correios até 31/05/2016, e o SIC-ECT não ter sido procurado com este objetivo (estudo exclusivo da LAI na ECT), até aquela data.
} 


\subsection{Metodologia}

A pesquisa caracteriza-se como uma pesquisa descritiva uma vez que se pretende fazer uma descrição das características do objeto da pesquisa, ao identificar a organização da informação e o cumprimento da Lei de Acesso à Informação a partir de fatos que já foram observados e registrados.

A abordagem aplicada a esta pesquisa é a qualitativa e o método de interpretação do contexto histórico se constitui como fundamento de ação política na construção do conhecimento. Foi adotada a concepção construtivista social, em que procuramos entender o mundo em que vivemos e trabalhamos, na busca de compreender os ambientes históricos e culturais dos sujeitos analisados (CRESWELL,2010, p.31), em que se identifica o compromisso social de práticas e saberes da Ciência da Informação, assim como identificamos a importância de que a CI se desenvolva vinculada à sociedade. Ao identificar a política de transparência pública das informações, através da LAI, e a organização da informação nos Correios buscamos as visões que os participantes têm da situação a qual está sendo estudada. Envolvemos os sujeitos desse processo - cidadãos e servidores públicos - no processo de busca dos resultados, ao analisar relatórios de pesquisa dos cidadãos e aplicar questionários aos empregados. Pesquisadores qualitativos procuram entender o contexto ou o cenário dos participantes, visitando tal contexto e reunindo informações pessoalmente (CRESWELL, 2010, p.31/32).

O recorte temporal pesquisado compreende o período de criação da Empresa Brasileira de Correios e Telégrafos, 1967/69, e o período de implantação da LAI, os três anos de vigência da Lei de Acesso à Informação nos Correios - 16 de maio de 2012 à 31 de dezembro de 2015.

O universo desta pesquisa se constitui de pesquisa bibliográfica, relatórios do sistema e-SIC, legislação relativa a transparência pública e acesso à informação, documentos internos da ECT, solicitados e recebidos pelo sistema e-SIC, das atas públicas de Reunião de Diretoria Executiva da ECT, e o questionário aplicado.

As técnicas utilizadas para a coleta de dados foram a aplicação do questionário, pesquisa bibliográfica, análise documental e observação direta das atividades de trabalho.

As fontes de informação utilizadas foram:

a) Documentos públicos, pesquisa bibliográfica e legislações relativas ao tema: realizamos busca na internet para quase a totalidade de documentos e legislações citadas e consulta ao Guia de Fontes de Acesso à Informação (PEREIRA). Os documentos referentes ao Termo de Ajuste e Conduta (TAC), foram obtidos como pedido de informação pela LAI, utilizando o sistema e- 
SIC, dirigido à ECT, e recebeu o número de protocolo NUP 99923.00111/2016-64, respondido com acesso concedido, em 14 de setembro de 2016;

b) Os relatórios disponíveis no sistema e-SIC: o Relatório de Pedidos de Acesso à Informação e Solicitantes e o Relatório de Recursos e Reclamações - contém os dados quantitativos e qualitativos dos pedidos de informação e recursos registrados ao longo do período deste estudo e estão disponíveis na internet (dados foram acessados em 9 de julho de 2016); o Relatório da Pesquisa de Satisfação dos solicitantes - este relatório não está disponível na internet, foi solicitado através da LAI, como pedido de informação dirigido à ECT, que recebeu o número de protocolo NUP 99923.001110/2016-10, e foi respondido com acesso concedido em 9 de setembro de 2016; e o Relatório de Avaliação da Integridade em Empresas Estatais $\mathrm{n}^{\mathrm{o}}$ 201503942/ECT - este relatório, elaborado pela CGU, busca conhecer o estágio evolutivo de como se encontra cada empresa estatal com relação às políticas e procedimentos relacionados à ética e integridade com a finalidade de diminuir o risco de corrupção e fraudes. Um dos itens avaliados é a Transparência do órgão, pelo qual o Serviço de Informação ao Cidadão (SIC) da ECT foi avaliado, está disponível na internet.

c) Questionário aplicado de forma individualizada aos gestores/pontos focais do SIC nas áreas da empresa: na implantação da LAI nos Correios, conforme será abordado no capítulo quatro, estabeleceu-se uma rede de representantes do SIC em cada Vice-Presidência, Departamento e Diretoria Regional, assim como, na Presidência, que foram denominados de Pontos Focais do SIC; para cada órgão foi criada uma caixa postal de email onde as demandas recebidas pelo sistema e-SIC eram encaminhadas em meio eletrônico para estes Pontos Focais, agilizando assim a tramitação dos pedidos. O questionário aplicado aos Pontos Focais do SIC trata de temas relacionados à Organização da Informação e como a mesma influencia o atendimento às demandas de informação dos cidadãos. O questionário foi elaborado em formato eletrônico no Google Form com questões mistas (fechadas e abertas) e foi respondido de forma eletrônica pelo informante, sem a presença do pesquisador. O questionário foi testado (pré-teste) por meio da aplicação de alguns exemplares em uma pequena população de 6 empregados (GERHARDT; SILVEIRA, 2009, p.70), que não apresentaram destaques. O questionário foi enviado a um total de 60 empregados dos Correios, entre os dias 02 a 08/05/2016, com prazo de retorno até o dia 20/05/2016. Foram recebidas 35 respostas $(58,3 \%)$.

O questionário foi organizado em blocos:

Bloco 1 - Identificação do servidor;

Bloco 2 - Identificação da área;

Bloco 3 - Requisitos de Qualidade da Organização da Informação; 
Bloco 4 - Requisitos de Política de Gestão, Segurança e Transparência da Informação;

Bloco 5 - Requisitos para disponibilização da informação.

Os blocos 1 e 2 se destinam a traçar um perfil do respondente em função da faixa etária, tempo de serviço na empresa, e de atuação junto à LAI. Já os blocos 3 e 4 tratam de requisitos relacionados à Organização da Informação, e o bloco 5, busca identificar a característica de pública ou privada que os empregados têm da empresa. Os entrevistados marcaram de 1 a 5 , sendo 1, referente à "discordo completamente" e 5, "concordo completamente" e o 6 , "desconheço".

Dados quantitativos relacionados aos pedidos de informação e dados qualitativos, que tratam da pesquisa de satisfação dos cidadãos (questionário misto que é aplicado no sistema eSIC), são utilizados para fundamentar este estudo.

Esta técnica envolve uma descrição da organização, a empresa pública da administração federal indireta e em seguida a análise de dados qualitativos que está conduzida concomitante com a coleta de dados e a realização de interpretações dos referidos relatórios. Esta pesquisa trabalhou com dados disponíveis no sistema e-SIC, organizou o processamento desses dados, através da geração, apresentação (gráficos e tabelas) e da interpretação. Pelos tipos de dados coletados é possível convertê-los em números, usando como processo de mensuração a escala classificadora ao identificar os pedidos de informação - perfil do cidadão (sexo, escolaridade, profissão, personalidade jurídica, localização); os motivos das negativas de acesso a informação; recursos registrados, e demais dados presentes nos relatórios.

A "Pesquisa de Satisfação" foi inserida no sistema e-SIC, pela CGU, ainda em 2012 com afirmativas e o cidadão tinha quatro opções de resposta: Discordo Totalmente, Discordo, Concordo e Concordo Totalmente. A partir de outubro de 2014, a redação das opções passou a ser em formato de pergunta, sem alteração do conteúdo arguido. No novo modelo as respostas passam a ter uma graduação de 1 a 5, sendo o 1, "Não Atendeu" e o 5, "Atendeu". No Quadro 1 apresentamos as diferenças entre os dois modelos de perguntas para o tipo de resposta "acesso concedido". 
Quadro 1 - Correlação das Perguntas na Pesquisa de Satisfação

\begin{tabular}{|c|c|c|c|c|c|}
\hline & $\begin{array}{c}\text { ACESSO } \\
\text { CONCEDIDO }\end{array}$ & Pergunta 1 & Pergninta 2 & Pergunta 3 & Pergunta 4 \\
\hline \multirow{5}{*}{ 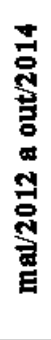 } & Texto & $\begin{array}{l}\text { A resposta é de fácil } \\
\text { compreensão }\end{array}$ & $\begin{array}{l}\text { A resposta atende às } \\
\text { minhas expectativas }\end{array}$ & $\begin{array}{l}\text { O órgăo foi prestativo e } \\
\text { condial na resposta }\end{array}$ & Comentários \\
\hline & \multirow{4}{*}{ Respostas } & *Discordo Totalmente & *Discordo Totalmente & *Discordo Totalmente & \multirow{4}{*}{ Redação livre } \\
\hline & & *Discordo & *Discordo & *Discordo & \\
\hline & & *Concordo & *Concordo & *Concordo & \\
\hline & & *Concordo Totalmente & *Concordo Totalmente & *Concordo Totalmente & \\
\hline \multirow{6}{*}{ 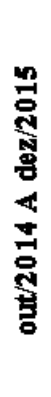 } & Texto & $\begin{array}{l}\text { A resposta fomecida foi } \\
\text { de facil compreensão? }\end{array}$ & $\begin{array}{l}\text { A resposta formecida } \\
\text { atenden plenamente ao } \\
\text { sen pedilo? }\end{array}$ & RETIRADA & Comentários \\
\hline & \multirow{5}{*}{ Respostas } & 1 - Não atendeu & 1 - Não atendeu & \multirow{5}{*}{ RETIRADA } & \\
\hline & & $2-$ & $2-$ & & \\
\hline & & $3-$ & $3-$ & & \\
\hline & & $4-$ & $4-$ & & \\
\hline & & 5 - Atendeu Plenamente & 5-Atendeu Plenamente & & \\
\hline
\end{tabular}

Fonte: elaborado pela autora, com base nos relatórios do sistema e-SIC

No caso das perguntas 1 e 2, procedeu-se à análise computando as respostas ao item "discordo totalmente" com o novo item "não atendeu", e assim com os demais. A pergunta três, será analisada apenas com as respostas até 2014, uma vez que foi retirada na nova versão. Quanto aos comentários, foram separados em positivos (elogios, agradecimentos) e negativos (criticas, reclamações) para interpretação da pesquisa. 


\section{REVISÃO DE LITERATURA}

A ciência não é algo que se possa justificar em si mesma, mas é sempre justificável por alguma necessidade social que deve ser atendida por esta ciência.

Gernot Wersig \& Ulrich Neveling

Para abordar o objetivo geral desta pesquisa buscou-se, na literatura disponível, o aporte para compreender a organização da informação e o acesso à informação no âmbito da estrutura de direito privado no Estado brasileiro, em particular na Empresa Brasileira de Correios e Telégrafos.

Este trabalho não apresentará as diversas visões existentes na literatura sobre os temas apontados. Há uma opção pelo materialismo histórico e pelo materialismo dialético (ALTHUSSER; BADIOU, 1979, p.43). A opção pelo pensamento marxista está expressa na referência bibliográfica e assim, apresenta a concepção de Estado enquanto instituição que tem como função assegurar e conservar a dominação e a exploração da classe dominante, e que questiona até que ponto pode ser ele transformado em instrumento da sociedade (MARX, 1999, p.40). Neste contexto insere-se a Transparência do Estado, onde a LAI é objeto de nosso estudo, que se converte em um valor fundamental nas democracias de nossa época (ZEPEDA, 2012, p.9) e possibilita a produção de conhecimentos.

O materialismo histórico como teoria da natureza específica da estrutura, que constitui toda a formação social dependente de um modo de produção determinado (infraestrutura econômica, a superestrutura jurídico-política e a superestrutura ideológica), nos permite fundamentar qual o nível dessa dependência e sua autonomia relativa (ALTHUSSER; BADIOU, 1979, p.43). O materialismo dialético nos auxilia no processo de identificação da produção dos conhecimentos, uma teoria das condições reais - materiais e sociais - da produção desse conhecimento, em que o acesso à informação é condição essencial.

O método dialético de Marx, segundo Chagas (2011, p.2/3) tem dois momentos inseparáveis: a investigação (ou a pesquisa) e a exposição (ou a apresentação). O primeiro é o esforço prévio de apropriação, pelo pensamento, das determinações do conteúdo do objeto no próprio objeto, e o segundo é uma expressão ideal do movimento efetivo do real. A apropriação analítica, reflexiva do objeto pesquisado para depois expor adequadamente, sistemática e criticamente. 
No mesmo caminho, seguimos na Ciência da Informação abordando o compromisso social desta ciência, e a importância da organização da informação para o acesso às informações públicas pelos cidadãos. A Ciência da Informação enquanto ciência tem seu foco nas relações sociais, nas necessidades sociais e na interação entre seres humanos. A defesa da responsabilidade social como um verdadeiro fundamento da CI, trazida por Wersig e Nevelling (1975, p.11), será tratada na ótica da Lei de Acesso à Informação nas transformações organizacionais.

É com este olhar que identificaremos a organização do Estado brasileiro, a organização da informação na empresa estatal e a implementação da LAI nos Correios.

\subsection{O Estado Brasileiro e as Estatais}

\subsubsection{O Estado: conceito e organização}

O trecho, a seguir, foi destacado de um artigo publicado no Jornal Folha de S. Paulo, intitulado "Os crimes do Estado se repetem como farsa", de autoria de uma integrante da Comissão Nacional da Verdade, no dia em que se comemorava o Dia Internacional do Direito à Verdade - 24 de março, data escolhida pela Organização das Nações Unidas (ONU). Esta referência nos ajuda a compreender o quanto é importante identificarmos o conceito e a organização do Estado para que o direito à informação seja uma realidade.

Todos os Estados totalitários se apoiam na supressão do direito à informação. Só assim conseguem silenciar, pelo menos por um tempo, a propagação das violações, dos abusos, das violências contra o cidadão praticadas em "nome da ordem", a revelar que na vida social não há direito perdido que não tenha sido usurpado por alguém. Falta de liberdades, de direitos e de acesso à informação são elementos fundamentais na consolidação do terrorismo de Estado (Kehl, 2013, p.1)

Engels (1974, p.194) define que, em geral, o Estado da classe mais poderosa, economicamente dominante, que por meio dele torna-se igualmente a classe politicamente dominante, vai adquirindo novos meios de dominar e explorar a classe oprimida. No estudo da 
origem do Estado, Engels afirma que na maior parte dos Estados históricos ${ }^{15}$, os direitos concedidos aos cidadãos eram regulados de acordo com as posses dos mesmos, o que evidencia ser o Estado um organismo para a proteção dos que possuem contra os que não possuem, "O Estado é a forma em que os indivíduos de uma classe dominante fazem valer seus interesses comuns e em que se resume toda a sociedade civil de uma época. " (MARX; ENGELS, 2006, p.10).

Entretanto, algumas questões sobre o Estado, trazidas por Marx, ainda continuam em aberto. A principal diz respeito a: como pode o Estado, na sociedade capitalista, ser transformado de um órgão imposto de cima à sociedade num órgão totalmente a ela subordinado?

A liberdade consiste em converter o Estado de órgão que está por cima da sociedade num órgão completamente subordinado a ela, e as formas de Estado continuam sendo hoje mais ou menos livres na medida em que limitam a "liberdade do Estado". (MARX, 1999, p.40)

A tradição marxista não levanta o problema da existência do Estado, e segundo Bourdieu o resolve pela definição das funções que ele preenche.

De Marx a Gramsci e a Althusser, todos sempre insistem em caracterizar o Estado pelo que ele faz e pelas pessoas para as quais ele faz o que faz, mas sem se interrogar sobre a própria estrutura dos mecanismos que supostamente produzem aquilo que o fundamentava. (BOURDIEU, 2014, p.32).

Ressalta, ainda, que é possível insistir mais sobre as funções econômicas do Estado, funções ideológicas - tratando do conceito de hegemonia de Gramsci ou de "aparelho ideológico de Estado" de Althusser; mas critica o fato da ênfase ser sempre posta nas funções e de se escamotear a questão do ser ou do fazer "dessa coisa que se designa como Estado" (BOURDIEU, 2014, p.32). Para Bourdieu alguns teóricos que negam este debate, do ser ou do fazer, fortalecem os que querem reduzir a questão do Estado à questão da função, substituir o "funcionalismo do melhor" por um Estado que funciona sempre para o chamado "funcionalismo do pior", a serviço dos dominantes, de maneira mais ou menos direta e sofisticada. Neste sentido, conclui que não se aprende nada sobre o mecanismo quando se interroga apenas a respeito das funções. Portanto, reveste-se de importância o que é e para fazer o quê, o Estado nos serve.

\footnotetext{
${ }^{15}$ Estados históricos: Estado ateniense e Estado romano
} 
Mandel (1982, p.22) afirma que o Estado é produto de uma opressão, da violência exercida por alguns contra outros, e confirma que Frederic Engels tem razão ao resumir a definição do Estado segundo a fórmula: um grupo de homens armados. O Estado também serve para fazer com que estes outros aceitem como “inevitável” essa forma de dominação de alguns.

Se o Estado é, em última análise, um grupo de homens armados, e se o poder duma classe dominante é fundado em última instância no constrangimento violento, não pode, no entanto, limitar-se exclusivamente a este constrangimento. Napoleão Bonaparte disse que tudo se pode fazer com baionetas, menos sentar-se sobre elas. Uma sociedade de classe que subsistisse unicamente pela violência armada encontrar-se-ia em estado de guerra civil permanente, ou seja, em estado de crise extrema.

Para consolidar a dominação de uma classe sobre outra é, portanto, absolutamente indispensável que os produtores, membros da classe explorada, sejam levados a aceitar como inevitável, permanente e justa a apropriação por uma minoria do sobre-produto social. Eis porque o Estado não desempenha apenas uma função de repressão, mas também uma função de integração ideológica. (MANDEL, 1982, p. 23)

Jardim (1999, p.33) destaca a importância em analisar os conceitos de Estado e hegemonia em Gramsci, onde o primeiro é compreendido como "todo o complexo de atividades práticas com a qual a classe dominante não somente justifica e mantém seu domínio, mas procura conquistar o consentimento ativo daqueles sobre os quais exerce sua dominação" (citando GRAMSCI apud CARNOY, 1990, p.90). O autor destaca ainda o conceito de aparelho de hegemonia como "um complexo de instituições, ideologias, práticas e agentes que só encontram sua unificação através da expansão de uma classe" (citando MENDONÇA apud JARDIM, 1999, p.36). Segundo Jardim (1999, p.37) “o bloco histórico constitui o vínculo orgânico entre estrutura social e superestrutura ideológica e política" o que corresponde a uma organização social concreta.

\begin{abstract}
A hegemonia não se constitui como aparelho a não ser por referência à classe que se constitui em e através da mediação de múltiplos subsistemas: aparelho escolar (da escola à universidade), aparelho cultural (dos museus às bibliotecas e arquivos), organização da informação, do meio ambiente, do urbanismo, etc. O aparelho de hegemonia é atravessado, como tal, pela luta de classes. Gramsci, portanto, amplia o Estado, incorporando a este o aparelho de hegemonia, além da sociedade civil. (JARDIM,1999, p.36)
\end{abstract}

Para Gramsci, ao se conseguir introduzir uma nova moral conforme uma nova concepção de mundo, acaba por introduzir também esta concepção determinando uma reforma 
filosófica total. Neste sentido é que o autor afirma: "a estrutura e as superestruturas ${ }^{16}$ formam um "bloco histórico", o conjunto complexo, contraditório e discordante das superestruturas, é o reflexo do conjunto das relações sociais de produção" (GRAMSCI, 1979, p.71)

$\mathrm{Na}$ disputa pela hegemonia, o uso da violência e da coerção tem se alternado frequentemente nos Estados modernos (JESSOP, 2009, p. 137/8 apud POULANTZAS, 1976a).

O período iniciado no século XIX, e muitas vezes esticado até a Primeira Guerra Mundial, foi o século da Revolução Industrial inglesa, de sua difusão, de sua hegemonia e, ao mesmo tempo, de sua superação por outros processos socioeconômicos de igual magnitude, que ocorreram em outras formações sociais, na Europa e fora dela (CURY, 2006, p.16). Da Revolução Francesa à Revolução Industrial, foram muitas as mudanças na sociedade europeia e americana, com reflexos em todo mundo ocidental, com o protagonismo das novas ideias oriundas do Iluminismo.

A Declaração dos Direitos do Homem e do Cidadão (1789), com 17 artigos, fruto da Revolução Francesa, no seu artigo $11^{\circ}$ declara "a livre comunicação das ideias e das opiniões é um dos mais preciosos direitos do homem; todo cidadão pode, portanto, falar, escrever, imprimir livremente, respondendo, todavia, pelos abusos desta liberdade nos termos previstos na lei" e no artigo $15^{\circ}$, “A sociedade tem o direito de pedir contas a todo agente público pela sua administração". Percebemos que os conceitos de liberdade de informar e ser informado já estavam presentes nos direitos dos cidadãos, com a (re) produção do conhecimento em meio físico: escrever e imprimir. A liberdade do Estado começava a ser desenhada pela sociedade.

A experiência da Revolução Francesa foi extremamente rica. O episódio da Comuna de Paris ${ }^{17}$ (março-maio de 1871) quando se põe o problema da passagem do Estado em que a classe dominante é a burguesia para o Estado em que a classe dominante será o proletariado, confirma para Marx a dependência do Estado diante da sociedade civil e do poder político (BOBBIO, 2006, p.160). Segundo Bobbio, para Marx a dependência do poder estatal em relação ao poder de classe é tão rigorosa que a passagem da ditadura da burguesia para a ditadura do proletariado não pode acontecer simplesmente por meio da conquista do poder estatal, isto é, daquele aparelho de que a burguesia se serviu para exercer o seu domínio, mas exige a destruição

\footnotetext{
${ }^{16}$ Nota da autora: estrutura (as relações sociais de produção) e superestrutura (as ideias, os costumes, os comportamentos morais, a vontade humana).

${ }^{17}$ A comuna de Paris foi a primeira experiência de poder socialista, uma insurreição popular que durou dois meses: "um Estado que daria um controle sem precedentes de todas as instituições, inclusive as coercitivas, à maioria dos eleitores [...] adequado à emancipação do trabalho através do estabelecimento de uma sociedade socialista." (BOTTOMORE, 1988, p.70)
} 
daquelas instituições e sua substituição por instituições completamente diferentes. Afirma ainda que "o Estado é sim uma máquina, mas ninguém pode manobrá-la a seu gosto: cada classe dominante tem de plasmar a máquina estatal de acordo com suas próprias exigências" (BOBBIO, 2006, p.161).

Bobbio (2006, p.164) apresenta a caracterização de Estado de transição da teoria de Marx, composta por dois elementos distintos: a supressão e a superação. Apesar de não destruir o Estado burguês anterior, não destrói o Estado como tal, mas ao construir um Estado novo, já lança as bases da sociedade sem Estado. E são essas características que servem para distinguir a teoria social-democrática da teoria anárquica. A primeira sustenta que o movimento operário tem como tarefa conquistar o Estado burguês por dentro, e não destruí-lo; a segunda sustenta que é possível destruir o Estado como tal sem passar pelo Estado de transição.

Mantendo-se separados os dois momentos dialeticamente unidos da supressão
e da superação, pode-se dizer que a supressão do Estado burguês não é
supressão do Estado, mas a condição para a sua superação. E é por isso que o
Estado burguês tem que ser em um primeiro momento suprimido,
diferentemente do que sustentam os sociais-democratas, para em segundo
momento, diferentemente do que sustentam os anarquistas, poder ser
superado. (BOBBIO, 2006, p.165)

Bourdieu (2014, p.30) trata o Estado como monopólio da violência física e simbólica, identificando-o como setor do campo do poder administrativo ou da função pública, em que se exerce a violência sobre a sociedade, desmistificando a ideia de Estado neutro e destacando os conflitos entre público e privado. Violência que está mais perceptível aos cidadãos, no Estado neoliberal. Bourdieu (2014, p.470/474) fortalece as ciências sociais ao destacar que desempenharam um papel capital ao analisarem os processos com a socialização dos riscos, com o social, com o público, rompendo a individualização do liberalismo. De um lado, as ciências sociais se construíram contra essa filosofia do individualismo e, segundo Bourdieu, houve uma espécie de frente comum de todas as ciências sociais até as ciências biológicas. As ciências sociais estão associadas à dissolução do indivíduo em benefício dos sistemas de relações em que ele está preso. Bourdieu destaca a obra de Burham ${ }^{18}$, que ao identificar essas mudanças na lógica do funcionamento das empresas, considera que as mesmas mudanças se encontram no nível do Estado para identificar a passagem de sistemas aparentemente imputáveis a um só em sistemas complexos em que há interpenetração do público e do privado,

\footnotetext{
18 James Burnham, L’Ère des organisateurs.Trad. de Hélène Claireau. Paris: Calmann-Lévy, 1947[1941]
} 
decisões, decisores e decididos: "a passagem dos owners (proprietários) aos manegers, da empresa possuída por um só, em que o chefe era o proprietário, à empresa administrada por um conjunto de pessoas" (BOURDIEU, 2014, p.473 apud BURHAM, 1947). Portanto, Bourdieu afirma que não se pode compreender o Estado moderno sem compreender essa espécie de "revolução cultural".

A Declaração Universal dos Direitos Humanos (DUDH), adotada pela Assembleia Geral da Organização das Nações Unidas (ONU) em 1948, soma-se as transformações apontadas por Bourdieu onde veremos expresso o direito ao acesso e a transmissão de informações e os direitos de cidadania. Princípios que serão as bases das leis de acesso à informação em vários países do mundo, a exemplo da LAI.

Toda pessoa tem direito à liberdade de opinião e expressão; este direito inclui a liberdade de, sem interferência, ter opiniões e de procurar, receber e transmitir informações e ideias por quaisquer meios e independentemente de fronteiras. (DECLARAÇÃO UNIVERSAL DOS DIREITOS HUMANOS, ONU, 1948 - Artigo 19º

Se o século XVIII e XIX foram ricos em produção de conceitos e reflexões, os séculos XX e XXI têm sido ainda mais ricos em experiências e mudanças. Na primeira metade do século XX ocorreram duas grandes guerras mundiais que refletiram fortemente na concepção de Estado e em sua organização. A expansão acelerada e desigual da industrialização capitalista no final do século XIX e início do século XX é resultado em parte pela diversidade das formações sociais por onde o capitalismo se implantou, mas que garantiram as principais características do sistema capitalista. "A base nacional sobre a qual o capitalismo foi erguido tendeu a fortalecer o peso político dos Estados nacionais e contribuiu, de forma dramática à eclosão dos conflitos mundiais do século XX. ” (CURY, 2006, p.173)

Segundo Cury (2006, p.175/177) um dos traços mais marcantes foi a mudança constante na base técnica da produção. A participação do Estado foi decisiva para a elaboração de programas e políticas voltadas para o desenvolvimento econômico, em países como Alemanha e Japão, e que vieram a ser o modelo no Brasil.

Bensaid (2000, p.28) afirma que de 1945 a 1970, a taxa de crescimento dos países industrializados foi excepcionalmente elevada, a produção mundial se multiplicou sete vezes e o comércio mundial quatro vezes. Segundo o autor esse crescimento foi a base de compromissos sociais nos diferentes setores do mundo, que moldou aos atores envolvidos - partidos reformistas, parlamentares, movimento sindical, movimentos populistas e anti-imperialistas no Terceiro Mundo, através do desenvolvimento do Estado-Providência e do culto do progresso 
nos centros imperialistas, reforçando posições reformistas, os pactos sociais e os fenômenos de burocratização do movimento operário. Outros fatores citados pelo autor são a euforia burocrática na União Soviética e na Europa Oriental quanto à perspectiva de alcançar, ou até superar a curto prazo, o Ocidente capitalista, assim como, os projetos de descolonização e desenvolvimento dos países de Terceiro Mundo. Esse contexto teria facilitado o surgimento de movimentos de contestação do sistema de dominação e lutas de libertação nacional como Argélia, Cuba, Indochina; lutas anti-burocráticas de massas na Tchecoslováquia e Polônia; movimentos de juventude, como "Maio de 1968"19, e ciclos de greves de massa na maior parte dos países desenvolvidos.

O crescimento do comércio internacional a partir da segunda metade dos anos 1970 é destacado por Bensaid como início da globalização da economia mundial e de crise dos Estados Nacionais.

A crise atinge aquilo que favorecia uma certa coesão social: a função redistributiva dos Estados. Daí a perda de legitimidade das instituições estatais derrotadas pelos efeitos conjugados das privatizações (reforço dos poderes econômicos privados), da globalização (perda de controle das relações econômicas e monetárias) e da desregulamentação. Esse fenômeno não afeta apenas os Estados dependentes e as classes dominantes frágeis. Ela começa também a atingir algumas burguesias europeias. (BENSAID, 2000, p.31)

A reestruturação liberal, o endividamento dos Estados (Estados Unidos, Itália, Bélgica) e das coletividades locais, crise aguda das finanças públicas levam ao questionamento dos mecanismos do Estado de Bem-Estar Social (indexação dos salários, serviços públicos, proteção social, privatização da seguridade social) em que a concorrência leva a divisão da classe dominante. Segundo Bensaid (2000, p.32) as classes dominantes existem enquanto tais através do Estado que as unifica. Os Estados existentes são ainda a forma necessária da dominação de classe, mas não a forma mais ideal para a fase de globalização da economia. E é essa desestabilização que passa a ser perceptível em vários países com escândalos de corrupção, negócios escusos, narcotráfico, máfia. As relações de dependências e de dominação ficam cada vez mais redistribuídas em conjuntos e blocos regionais. A consolidação de acordos e de órgãos internacionais, e outros problemas, surgem onde o Estado nacional não é mais o protagonista, mas instituições como o Banco Mundial, Fundo Monetário Internacional, União Europeia,

\footnotetext{
${ }^{19}$ Maio de 68: em maio de 1968 ocorreu uma greve geral na França e é considerado um dos maiores movimentos sociais do século XX, envolvendo trabalhadores, camponeses e estudantes.
} 
Mercosul. Ao mesmo tempo em que assistimos a crise e o deslocamento de alguns Estados, com ascenso dos nacionalismos, relações entre nações-etnias-Estado, multiplicação de conflitos regionais. $\mathrm{O}$ nacionalismo do oprimido que pode muito rapidamente se converter em nacionalismo opressor de suas próprias minorias. (BENSAID, 2000 p.39)

É neste contexto que Bensaid (2000, p.40) alerta para a necessidade de reformular uma proposta de contestação de conjunto da ordem estabelecida, onde a defesa da cidadania, como primazia sobre a nacionalidade, e da defesa da democracia com relação à universalidade dos direitos humanos, direitos civis e igualdades (igualdade homens/mulheres); direitos sociais e serviços públicos estejam em destaque.

O direito a ter opinião, a liberdade de expressão, de receber informação são conquistas presentes no Estado Democrático, que não pode existir sem reafirmar a cidadania ativa e a sociedade participante.

\subsubsection{O Estado brasileiro}

A organização do Estado brasileiro é um tema bem complexo. Nogueira (2011, p.19) destaca que a República brasileira nasceu de uma proclamação militar em 1889 e após um intervalo de quase quarenta anos, controlada por oligarquias civis quase antirrepublicanas, hostis à nação, ao Estado e à cidadania, voltaria a se reencontrar com as Forças Armadas nos anos de 1930. Portanto, para o autor o golpe militar de 1964 seria a volta as raízes da vida nacional. Por longos vinte anos o país viveu sob o patrocínio do regime militar nascido em 1964 e até o reencontro com a democracia, a eleição indireta de Tancredo Neves em 1985, foi por iniciativa de um dos generais no poder, Ernesto Geisel.

A ideologia dominante soma-se à máquina administrativa a serviço da exploração e às estruturas repressivas que protegem a classe dominante exército, polícia, justiça. Assim, o Estado moderno funciona por consenso e não somente por violência. O Estado é, simultaneamente, um instrumento para a expansão do poder da classe dominante pelos aparelhos de hegemonia (sociedade civil) e uma força repressiva (sociedade política) que mantém os grupos subordinados e desorganizados. (JARDIM, 1999, p.34)

Segundo Tavares (2000, p.1) o Brasil passou por uma oscilação permanente ao longo de dois séculos, entre uma ordem liberal oligárquica e um Estado interventor autoritário que geraram conflitos periódicos no pacto de dominação interna. A autora afirma ainda que as raras 
passagens pela democracia política no país nunca conseguiram estabelecer um Estado de Direito, com instituições capazes de conter dentro delas o seu próprio aperfeiçoamento e a moldura de regulação das lutas das oligarquias regionais e dos movimentos sociais. "A falta de acesso à terra, à educação e ao trabalho assalariado regular de nossa população rural e urbana nunca permitiu a formação de uma classe trabalhadora portadora de direitos de cidadania" (TAVARES, 2000, p.1). As reformas burguesas no Brasil sempre tiveram como limites dois medos seculares por parte de nossas elites: o medo do Império e o medo do povo, e assim as repúblicas - velha e nova - nunca incluíram as classes trabalhadoras num "pacto democrático". Neste sentido, baseado num pacto federativo, precário desde a constituição enquanto um país independente, se constituiu um Estado nacional, ora férreo, ora frouxo.

Nogueira (2011, p.22) afirma que os acontecimentos de 1964 foram um ponto de inflexão na história brasileira, não sendo apenas um golpe no Brasil, mas uma alteração nas formas do Estado e na qualidade do processo sociopolítico. Segundo Nogueira (2011, p.36), em sociedades complexas e fragmentadas como o Brasil, inseridas em posições subalternas no capitalismo globalizado, seria pouco provável pensar a mudança e a organização de novas hegemonias sem o pleno emprego do recurso democrático ao diálogo e à negociação. Para qualquer política de alianças o Estado é um recurso técnico e ético da reforma social. "Não pode haver Estado democrático que se afirme sem cidadania ativa e sociedade participante, mas a ausência de Estado reduz o social a mero mundo dos interesses, a território de caça ao mercado" (NOGUEIRA, 2011, p.38).

Dagnino e Costa (2013) caracterizam o Estado que herdamos do período militar como um Estado que combinava autoritarismo com clientelismo, hipertrofia com opacidade, insulamento com intervencionismo, deficitarismo com megalomania e que não atendia nem ao projeto da direita e nem da esquerda. O Estado após mais de 20 de anos de autoritarismo não teria sido o prometido para justificar o golpe militar, segundo os autores. Uma dívida imposta à população, um aparato repressivo a serviço do regime militar, que sufocava qualquer oposição, compunha o retrato do país. Já os governos civis que sucederam os governos militares pregavam a restrição do Estado, defendendo a doutrina neoliberal: privatização, desregulação e liberalização. (DAGNINO; COSTA, 2013, p.17/19)

A democracia é uma condição necessária para construir um Estado que promova o bem-estar das maiorias. Só o conjunto que ela forma como uma outra condição necessária - a capacidade de gestão pública - é suficiente. Só a democracia aliada à eficiência de gestão pode levar ao "Estado necessário" para a transformação da sociedade brasileira no sentido que queremos. (DAGNINO; COSTA, 2013, p. 19) 
Os autores alertam sobre o mecanicismo afirmando que, em uma sociedade de classes, a "ocupação" do Estado pela classe dominante leva inevitavelmente a políticas que mantêm e reproduzem a dominação desta sobre as demais classes. Também consideram ingênua a concepção de Estado neutro, que supõe uma mudança na correlação de forças na sociedade, em um grau que permita o controle do seu aparelho por forças progressistas e isso levaria, automaticamente, a políticas capazes de impulsionar a desconcentração de poder e a equidade social.

A visão de que o aparelho de Estado seja um simples instrumento neutro, capaz de, de uma hora para outra, alterar sua orientação e seu modus operandi de forma a implantar políticas que contrariam as premissas que o geraram, pode levar a uma postura voluntarista que tende a minimizar as dificuldades que sempre enfrentaram os governos de esquerda. (Ibid, p. 23)

Segundo Nogueira (2011, p. 28), o processo de redemocratização no Brasil avança no final do século XX de modo não linear: a promulgação da "Constituição Cidadã" 20 em 1988, a volta da eleição de seus presidentes, a normatização da vida democrática, o domínio da inflação, a tomada de consciência da questão do Estado e da gestão pública, e o mergulho na globalização.

Entre 1964 e 1984, a sociedade foi exposta a um estado hiperativo, terrorista e burocrático, que comprimiu quase ao limite do suportável. O "estatalismo" de então impulsionou parcialmente o crescimento econômico, criou novos beneficiários de seus serviços e reorganizou as relações entre Estado e mercado, mas ao mesmo tempo desvirtuou completamente o Estado, na medida em que dissociou da sociedade, o impregnou de privatismo e o distanciou da cidadania. Após interregno inaugural da Nova República (19851989), a década de 1990 irá privilegiar a ideia de que seria preciso eliminar o "mal" que o Estado estava causando à sociedade, ao mercado e à liberdade. Fez-se em nome disso uma reforma, que gerou um outro padrão de Estado e de intervenção estatal. Agora, em pleno século XXI, trata-se de saber se esse padrão é adequado, se deve ser mantido ou se é mais recomendável descartalo. Parece pouco provável que se consiga avançar em termos reformadores e reorganizar a sociedade se o coração do sistema permanecer fora de foco ou ignorado. Se o governo está mesmo preocupado em abrir caminho para a construção de uma nova hegemonia (e não há por que duvidar disso), como então deixar o Estado de lado?" (NOGUEIRA, 2011, p.34)

Entretanto, o autor destaca que a própria natureza concentrada do capitalismo em termos de propriedade, renda e poder restringe e deforma o processo democrático como já apontado por vários autores. Neste sentido afirma que a reforma do Estado deve ser o prolongamento de 
uma reforma democrática e social porque deve se destinar a reformular as relações entre o Estado e a sociedade civil. (NOGUEIRA, 2011, p.79)

O Estado Herdado remete-nos ao que podemos considerar como a primeira reforma da administração gerencial no Brasil: o Decreto-Lei nº 200/1967 (DL200). Segundo BresserPereira (1996, p.7), a partir do pressuposto da rigidez da administração direta e da maior eficiência da administração descentralizada toda a ênfase foi dada à descentralização, mediante autonomia da administração indireta. Entretanto, reconhece que isso teve duas consequências inesperadas e indesejáveis. Ao permitir a contratação de pessoal sem concurso público facilitou a sobrevivência de práticas patrimonialistas e fisiológicas e, por outro lado, não se preocupou com as mudanças no âmbito da administração direta e central. $\mathrm{O}$ autor salienta, ainda, que na medida em que se inicia a crise política do regime militar, já nos anos 70 , se agrava a situação da administração pública brasileira em que a burocracia estatal é identificada com o sistema autoritário em pleno processo de degeneração.

A reforma operada em 1967 pelo Decreto-Lei no 200, entretanto, constitui um marco na tentativa de superação da rigidez burocrática, podendo ser considerada como um primeiro momento da administração gerencial no Brasil. Mediante o referido Decreto-Lei, realizou-se a transferência de atividades para autarquias, fundações, empresas públicas e sociedades de economia mista, a fim de obter-se maior dinamismo operacional por meio da descentralização funcional. Instituíram-se, como princípios de racionalidade administrativa, o planejamento e o orçamento, o descongestionamento das chefias executivas superiores (visando a desconcentrar e descentralizar), a tentativa de reunir competência e informação no processo decisório, a sistematização, a coordenação e o controle.

O paradigma gerencial da época, compatível com o monopólio estatal na área produtiva de bens e serviços, orientou a expansão da administração indireta, numa tentativa de "flexibilizar a administração" com o objetivo de atribuir maior operacionalidade às atividades econômicas do Estado. (KLERING et al, 2010, p.6)

A autonomia administrativa foi considerada como sendo sinônimo de "independência", tal o grau de "flexibilização" conferida às empresas estatais como veremos a seguir no subitem 2.2 que trata da ECT. Mais adiante trataremos da Administração Indireta determinada pelo DL200.

Segundo Klering et al (2010, p.5) a disposição para "reformar administrativamente" o Estado brasileiro era antiga, presente desde a década de 1930 e assumiu maior relevância em meados da década de 1990, pela institucionalização da Lei da Reforma do Estado Brasileiro.

$\mathrm{Na}$ década de 1980 em uma nova tentativa de reforma da administração burocrática e na busca de uma administração gerencial do Estado, é criado o Ministério da Desburocratização 
e o Programa Nacional da Desburocratização - PrND, com objetivo de revitalizar e agilizar as organizações e posteriormente, essas ações de combate à burocratização dos procedimentos foram dirigidas ao Programa Nacional de Desestatização, segundo Klering et al (2010, p.7). Este programa visava conter os excessos da expansão da administração descentralizada, estimulada pelo DL200.

Klering et al (2010) destaca a importância da criação, em 1986, da Fundação Escola Nacional de Administração Pública (ENAP) voltada para formar, aperfeiçoar e profissionalizar o servidor público de nível superior na perspectiva da modernização do setor público.

A Constituição Federal de 1988 (CF) garantiu a fixação dos servidores no serviço público e aprovação do ingresso por concurso público, que foi uma grande vitória dos que defendiam o fim do sistema patriarcal ainda presente na administração pública, em que as contratações passavam por relações partidárias e pessoais. O movimento sindical nesse período, organizado pelas centrais sindicais, Central Única dos Trabalhadores (CUT) e Central Geral dos Trabalhadores (CGT), reivindicavam a estabilidade no emprego e para os servidores públicos, o ingresso exclusivo por concurso público. A instituição do Regime Jurídico Único (RJU) para os servidores civis da União, dos Estados e Municípios e Distrito Federal, incluindo as fundações e autarquias, também respondeu às reivindicações do movimento dos servidores públicos, em especial das universidades. Após uma longa greve em 1987 nas universidades federais, foi aprovada a Lei n 7.596 (conhecida como a Lei da Isonomia) que alterou dispositivos do Decreto-lei $n^{\circ}$ 200/69, modificado pelo Decreto-lei $n^{\circ}$ 900/69, e pelo Decretolei n ${ }^{\circ}$ 2.299/86, instituindo assim, as Fundações Públicas na estrutura da Administração Indireta, e a isonomia de tratamento entre seus servidores. A defesa dessas teses, incorporava uma concepção de não intervenção política partidária na gestão pública, uma vez que a mudança de gestor, implicava no ingresso e demissão dos servidores por critérios não republicanos. A autora deste trabalho participou ativamente das negociações no Congresso Constituinte, e depois no âmbito das discussões entre servidores públicos, para a construção do RJU.

O período após a promulgação da CF foi marcado pela primeira eleição direta para Presidente da República após regime militar. Segundo Klering et al (2010, p.7), o governo Collor (1990 - 1992) ao priorizar o ajuste fiscal, através incentivos à liberação comercial e a privatização, promoveu uma reforma administrativa do aparelho do Estado com o objetivo de resgatar a eficiência e dignidade do serviço público. Um grande número de servidores foram demitidos e se aposentaram, em um período no qual os mesmos foram chamados de "marajás" e desqualificados perante a nação. O governo Itamar Franco (1992-1994) implantou o Plano Real, como promessa de estabilização da economia, conduzido pelo professor da USP, 
Fernando Henrique Cardoso, que se elege presidente nas eleições de 1994. Klering et al (2010, p.7) ressalta que a diferença fundamental do novo modelo de administração pública está na forma de controle, que passa a basear-se nos resultados e não nos processos. Passou-se também a definir metas para cada órgão, dando maior autonomia na gestão de recursos para depois realizar o controle dos resultados alcançados. De acordo com os autores há valorização da transparência e participação dos cidadãos. É neste período que é promulgada a Lei de Licitação (Lei $\left.{ }^{\circ} 8.666 / 93\right)$.

A Reforma Administrativa promovida no governo Fernando Henrique Cardoso (1995 2002), retirou do controle do Estado várias políticas e ações sociais, não apenas pela entrega ao setor privado, mas para organizações chamadas de não governamentais (ONGs) que tinham como objetivo, segundo Klering et al (2010, p.8), maior eficiência e qualidade nos serviços prestados aos cidadãos.

Por outro lado, no plano social, a diferença entre a proposta neoliberal e o novo Estado social-liberal que está surgindo está no fato de que os verdadeiros neoliberais querem a retirada do Estado também da área social. Criticam fortemente a intervenção do Estado social, que no Primeiro Mundo se manifestou como welfare state, porque esta intervenção mesmo na educação e na saúde acabaria sendo objeto de rentseeking ${ }^{21}$ por parte de grupos especiais de interesses, formados por empresários, por grupos de classe média, por funcionários, que assim privatizam a coisa pública. Adotando um individualismo radical e carente de realismo político, pretendem que a educação e a saúde, por mais importantes que possam ser, sejam problemas que as famílias e os indivíduos devam resolver e financiar. Entretanto, o resultado de tal crítica e da resposta social-democrática não é o Estado liberal (pregado pelo neoconservadorismo), nem o Estado social-democrata (outro nome para o Welfare State), mas o Estado social-liberal, que continua responsável pela proteção dos direitos sociais, mas que garante essa proteção deixando gradualmente de exercer de forma direta as funções de educação, saúde e assistência social para contratar organizações públicas não estatais para realizá-las.(BRESSER-PEREIRA, 1998, p.3)

Além de estruturas de direito privado dentro do Estado, na administração indireta, outras formas de descentralização dos serviços públicos inspiradas nos modelos americano e anglosaxão foram instituídas no Brasil.

Objetivando maior eficiência e qualidade nos serviços prestados aos cidadãos, o cenário da Reforma empreendida no Brasil prevê diferentes estratégias e formas de descentralização dos serviços públicos: via instituição de mecanismos de privatização, visando a reduzir o tamanho do aparelhamento

\footnotetext{
${ }^{21}$ Busca de renda econômica (tradução livre)
} 
administrativo do Estado, bem como a dinamizar e flexibilizar sua atuação; a quebra de monopólios, para tornar competitivas as atividades exercidas com exclusividade pelo poder público; o recurso a autorizações, permissões e concessões de serviços públicos, delegando-se estes serviços ao Terceiro Setor e à iniciativa privada; o estabelecimento de parcerias com entidades públicas ou privadas para a gestão associada de serviços públicos, ou serviços de utilidade pública, por meio de convênios, consórcios e contratos de gestão; a terceirização como forma de se buscar o suporte de entidades privadas ao desempenho de atividades-meio da administração pública. (KLERING ET AL, 2010, p. 8)

O governo Lula (2003 - 2010) em contraposição as reformas do Estado anteriormente propostas, executou políticas voltadas para um Estado promotor da inclusão social (Ibid, p.9). Os autores consideram que as ações do governo Lula envolvem três categorias nas quais foram implantadas reformas estruturais (Reforma do Estado e do seu aparelho) e reformas administrativas (da administração pública), à semelhança da década de 1990, à busca de uma melhor qualidade dos serviços públicos. Estas categorias envolveram a reforma do modelo de gestão pública (integração de programas governamentais e avaliação de desempenho), inovação gerencial e a reformas na estruturação do executivo federal (realização de concursos públicos, valorização do servidor, novas concepções institucionais, etc.). (KLERING et al, 2010, p.8 apud FADUL; SOUZA, 2005).

O Estado brasileiro tem toda sua estrutura e organização estabelecidas na Constituição Cidadã, logo na sua abertura, estabelece ser uma República Federativa, formada pela união indissolúvel dos Estados, Municípios e do Distrito Federal, e constituir-se em Estado Democrático de Direito. Esta Carta Magna deve ser seguida e cumprida por todos os entes federados e pelos Poderes da República. Vários de seus artigos necessitaram de regulamentação, para dar corpo e alma à norma legal. Entretanto, alguns de seus artigos até hoje não foram regulamentados, e outros, apenas recentemente, como a Lei de Acesso à Informação - Lei 12.527, aprovada em 2011, 23 anos após a promulgação da Constituição. Apenas na última década foi possível a aprovação de instrumentos legais e normativos que garantissem a transparência pública (Lei Complementar no 131/2009 - Portal da Transparência); o combate a abusos de poder na função pública (Lei de Conflito de Interesses - Lei n ${ }^{\circ} 12.813 / 2013$, e a Lei Anticorrupção - Lei n $\left.{ }^{\circ} 12.846 / 2013\right)$. O que confirma o quanto nossa democracia ainda é jovem e não está completamente consolidada.

Nesse novo contexto, o papel do Estado está sendo crescentemente demandado, em que não pode ser entendido como empecilho à realização do seu papel, mas como solução, ampliando e profissionalizando sua esfera de atuação, como indutor, articulador, catalisador e orquestrador principal do 
desenvolvimento, com a forte participação da sociedade, sem clientelismo, mas com transparência e responsabilidades consensuadas e compartilhadas. (KLERING et al, 2010, p.9)

Em maio de 2014, a Presidenta Dilma assinou o Decreto $n^{\circ} 8.243$ que instituía a Política Nacional de Participação Social (PNPS) e o Sistema Nacional de Participação Social (SNPSP) onde encontrava-se entre suas diretrizes, dentre outras, "o reconhecimento da participação social como direito do cidadão e expressão de sua autonomia" e "o direito à informação, à transparência e ao controle social nas ações públicas, com uso de linguagem simples e objetiva, consideradas as características e o idioma da população a que se dirige". Um instrumento de ampliação da participação do cidadão no controle do Estado, na administração pública. Entretanto, dois dias após a vitória da reeleição da presidenta, dia 28 de outubro daquele ano, a Câmara dos Deputados aprova o projeto de lei que susta os efeitos do referido decreto.

No momento em que desenvolvemos nossa pesquisa, nossa jovem democracia passa por um sério abalo. No dia 31 de agosto de 2016, a Presidenta Dilma Rousseff, eleita em 2014 pelo voto direto, por mais de 54 milhões de brasileiros, foi impedida e afastada do poder pelo Senado Federal por crime de responsabilidade, do que foi chamado de "pedaladas fiscais" pela mídia (CARTA CAPITAL, 2016). Todo o processo de impedimento tem sido considerado por especialistas, juristas e pela própria Presidenta um golpe ${ }^{22}$ de Estado, um golpe na democracia brasileira, resultado da representação da classe dominante no parlamento e no uso de seus espaços de poder.

De fato, estamos vivendo um momento emblemático na vida política e social do país, depois de 12 anos de avanços significativos nas políticas públicas de cunho social. Nessa conjuntura, se destacam o diagnóstico da crise e a cobertura da mídia burguesa e, aliado a esse fenômeno o crescimento do horizonte sombrio do conservadorismo do Congresso Nacional, especialmente, na Câmara dos Deputados, tendo à frente a figura nefasta do seu presidente, deputado Eduardo Cunha (PMDB-RJ). Com efeito, de acordo com analistas políticos, esse Parlamento é o mais conservador desde 1964. Há, neste sentido, o "avanço" da "vanguarda do atraso" composta, fundamentalmente, pela chamada bancada BBB: bíblia (pastores fundamentalistas), boi (agronegócio) e bala (ligada diretamente à polícia e às empresas de segurança, ao aparato repressivo e contra o estatuto do desarmamento). De acordo com o Levantamento do DIAP (Departamento Intersindical de Assessoria Parlamentar), essa "bancada do conservadorismo" é composta por 251 deputados eleitos. A bancada ruralista é composta por 153

\footnotetext{
${ }^{22}$ Matéria publicada na Agência Brasil-ECB, "Na véspera do julgamento pelo Senado, Dilma diz que há um golpe em andamento" (DINIZ, 2016)
} 
deputados; a bancada evangélica, por 75, e a bancada da repressão, por 23. (SILVA; PIRES; PEREIRA, 2016, p.7) ${ }^{23}$

Como explicita Dagnino (2013, p.6) sem democracia não há participação e transparência nas decisões, nas prestações de contas, não há responsáveis, só há impunidade.

Por fim, como afirma Mendel (2009) é fundamental, para a garantia do livre fluxo de informações e ideias, de que os órgãos públicos tenham claro que as informações que detenham não são para eles próprios, mas em nome do povo, e são o cerne da noção de democracia. Sem um Estado vigoroso, democrático e socialmente vinculado, não há como ter uma articulação virtuosa entre governabilidade, desenvolvimento, igualdade e justiça social (NOGUEIRA, 2011, p. 79).

\subsubsection{A Cultura do Sigilo}

Para Zepeda (2012, p.14/15), o homem que está livre das correntes e contempla a realidade é, naturalmente, o filósofo, mas, no sistema platônico, é também o político, o único capaz de entender o que é bom, a virtude, a beleza e a verdade para além de todas as aparências e toda opinião. O conhecimento das verdades da prática política é, portanto, reservado para a aqueles, os participantes da aristocracia do intelecto, que podem transcender o preconceito e a ignorância da população. Este é o sentido de justiça que está na origem dos arcana imperii ${ }^{24}$, isto é, dos segredos do poder que estabelecem por dentro e por fora do poder político e, portanto, hierarquizam as pessoas com relação à prática política e com a qualidade dos conhecimentos e argumentos que podem ter a sua disposição. Bobbio (2015, p.30) trata do Estado absoluto, que em sua doutrina os arcana imperii são tema recorrente, em que o poder autocrático oculta ou mente considerando isso um ato licito de governo e reafirma que a opacidade do poder é a negação da democracia.

Entretanto, arcana imperii não só se refere aos segredos do império ou do estado, mas a verdades que possuem um significado quase sagrado, ritual, ou seja, mistérios insondáveis da

\footnotetext{
${ }^{23}$ Felippe (2015) em artigo publicado na Revista Carta Maior descreve a composição da Câmara dos Deputados em referência nesta citação

${ }^{24}$ Foi o grande historiador romano Tácito (55-120), o primeiro que denominou arcana imperii esses pedaços de conhecimento, esses mistérios da política. Arcana (de raiz indo-européia: arek) significa segredo, algo que é retido ou que se guarda. (ZEPEDA, 2012, p.15)
} 
política. Porque os arcana imperii não se reduzem a condição de informações plenas sobre questões públicas, mas para selecionar, informações privilegiadas, que define o poder como o sujeito de quem detém e administra. (ZEPEDA, 2012, p.15)

É no cenário dos anos 1970, que Bobbio começa a analisar e estudar o "poder invisível" ao admitir que há, por baixo do governo visível um outro governo.

Sempre houve e sempre haverá um poder invisível contra o Estado. [...] [...] e infelizmente nada indica que tenha deixado de existir, um poder invisível dentro do Estado, que abarca os serviços secretos voltados à segurança interna e externa do Estado, a organização da espionagem e da contraespionagem [...] Em regime democrático é absolutamente inadmissível a existência de um poder invisível que atue paralelamente ao poder do Estado, ao mesmo tempo dentro e contra, que certos aspectos é concorrente e sob outros é conveniente, que emprega o segredo não para abater o Estado mas tampouco para servi-lo, que se vale dele principalmente para evitar e até violar impunemente a lei, assim como, para obter favores extraordinários ou ilícitos [...]. (BOBBIO, 2015, p.38)

A cultura do sigilo está inserida nas sociedades onde não há liberdade de expressão.

O regime militar brasileiro instaurou uma ordem em que as liberdades fundamentais do povo foram tolhidas e efetivou uma ampla campanha de censura aos meios de comunicação, às manifestações artísticas, políticas, intelectuais ou qualquer outro fato que significasse um ideário diverso do que consideravam seguro à manutenção do regime instalado (BARACCHINI, 2008, p.120).

Jardim $(1999$, p.85/86) identifica este período como de um distanciamento do Estado brasileiro da sociedade civil, de uma forte centralização no "Governo da União" e "marcadamente autoritário, acirra a concentração de renda e os desajustes sociais". A criação de órgãos como o Serviço Nacional de Informação (SNI), o Departamento de Operações e Informações do Exército (DOIEx), o Centro de Informações do Exército (CIEx), Centro de Informações da Marinha (CIM), entre outros, e o fortalecimento do Departamento de Ordem Política e Social (DOPS) em todos os estados brasileiros, demonstram o controle do Estado da informação.

Carvalhêdo e Rodrigues (2008, p.2) apontam que as políticas de informação do Estado brasileiro adotadas a partir do Regime Militar estão relacionadas à Guerra Fria, período de disputa travada entre os Estados Unidos e a então União Soviética com um forte componente ideológico internacional contra e pró-comunista, estimulando a propaganda cultural e a criação de instituições de informação estatais. 
O aparato repressivo desenvolvido pela Ditadura Militar legalizado, através dos Atos Institucionais 1 e 5 (AI-1; AI-5) e a doutrina de Segurança Nacional (FERNANDES, 2009, p.7) são apenas alguns exemplos de atos, retirando do cidadão brasileiro direitos como o voto e a liberdade de expressão.

A burocratização dos órgãos responsáveis pela repressão para efetivar ou promover a propagação do medo na população são destacados por Lopes e Konrad (2013) ao analisarem os arquivos da repressão e a LAI no Brasil e na Argentina. Assim, produziram importantes documentos que constituem hoje, os arquivos da repressão. Estes têm grande importância social, já que possuem informações referentes aos crimes de violação de direitos humanos cometidos pelos agentes públicos (LOPES; KONRAD, 2013, p.7).

Se durante séculos o uso do segredo foi considerado essencial para a arte de governo como nos destaca Bobbio (2015, p.43), ele é, hoje, típico dos partidários dos governos autocráticos e totalitários. No Estado democrático, o direito à informação é uma das tantas formas de direito concedido aos cidadãos.

Existe uma relação histórica constante entre os regimes autoritários e a censura informativa ou a limitação do acesso aos conhecimentos e informações da esfera política. $\mathrm{O}$ estatuto ou condição de cidadão livre, próprio das sociedades modernas, supõe o conhecimento das questões públicas. (ZEPEDA, 2012, p. 16, tradução da autora)

Os aspectos da supressão do direito ao acesso a informação e o sigilo que irão impactar na sociedade brasileira e na administração dos Correios, sob o comando dos militares, podem ser identificados para uma melhor compreensão do momento atual.

O serviço postal brasileiro está em operação desde o século XVII, mas dois momentos são considerados marcantes nos Correios: a década de 1930, com a criação do Departamento de Correios e Telégrafos e a década de 1960, que o transforma na Empresa Brasileira de Correios e Telégrafos (TEIXEIRA, 2013, p.31). O serviço postal sempre esteve sujeito a restrições e proibições dos governantes que determinavam a circulação e distribuição das correspondências. A censura postal no Brasil foi oficialmente instituída em 1917, no período da $1^{\text {a }}$ Guerra Mundial (1914/1919) e teria sido abolida em $1948^{25}$, mas há comprovações de que houve censura postal em vários outros períodos da história, como durante a ditadura militar.

\footnotetext{
${ }^{25}$ Não localizamos referências bibliográfica, apenas o registro do filatelista Rubem Porto Jr com seu acervo em vídeo (PORTO JR, 2014)
} 
Na página da Sociedade Philatelica de São Paulo há várias imagens de cartas censuradas do período de 1917 a 1937, que abrangem a $1^{\text {a }}$ Guerra Mundial, o Tenentismo e a Coluna Prestes, e a Revolução de 30 apresentadas na Exposição/Palestra Censura Postal, 1917 a 1930 pelo Palestrante Rubem Porto Jr. (PORTO JR, 2014).

Figura 1 - Correspondência Brasileira Censurada $1^{\text {a }}$ Guerra Mundial

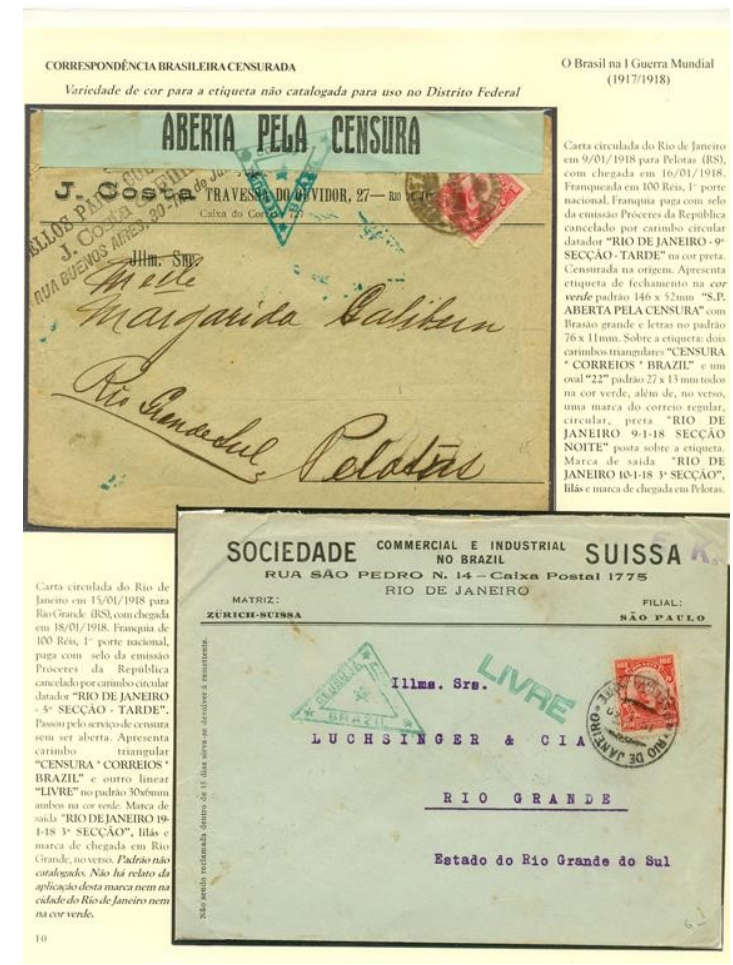

Fonte: Sociedade Philatelica de São Paulo

Fernandes (2009) destaca que o Serviço Nacional de Informações (SNI) foi o responsável pelas bases do aparato repressivo desenvolvido, possibilitado pela legalização da ofensiva repressiva estabelecida pelo Ato Institucional-1 (AI-1). Criado e chefiado inicialmente por Golbery do Couto e Silva (1964), o SNI estava inserido nas diretrizes da Doutrina de Segurança Nacional, e tinha como objetivo "coletar e analisar informações pertinentes à Segurança Nacional, à contrainformação e à informação sobre questões de subversão interna". (FERNANDES, 2009, p.3)

Cabia ao CIEx repassar as informações para o SNI, que depois as irradiavam para os órgãos de repressão direta. Para obter as informações desejadas sobre os exilados, esse centro de espionagem recorria a vários métodos: infiltração de agentes no meio dos exilados, violação de correspondência, rastreamento de veículos considerados suspeitos que circulavam pela fronteira, controle das 
atividades e dos "pombos-correios" dos principais líderes da esquerda, etc. (Ibid, p.6, grifo da autora)

Serviços de inteligência são agências governamentais responsáveis pela coleta, pela análise e pela disseminação de informações consideradas relevantes para o processo de tomada de decisões e de implementação de políticas públicas nas áreas de política externa, defesa nacional e provimento de ordem pública (CEPIK, 2003, p.13). Cepik destaca que essas agências governamentais também são conhecidas como serviços secretos ou serviços de informação. Podemos identificar que nos governos militares funcionavam como agentes da repressão e utilizaram o aparato do Estado para controlar os órgãos públicos e seus funcionários.

Os Correios são um exemplo concreto dessa realidade. A presença militar foi marcante não apenas no aparato repressor, mas na organização do trabalho. Bovo (1997, p.10) identifica que o processo de modernização da ECT nessa época se deu em função de um trabalho de reorganização e reestruturação dos serviços de correios, concebida por uma missão de técnicos franceses ${ }^{26}$ que a filosofia administrativa e de gestão da força de trabalho adotada foi a da Organização Racional do Trabalho, ou Administração Científica, de acordo com os princípios de Taylor, Ford e Fayol, repercutindo profundamente sobre os trabalhadores da ECT. Segundo Bovo, essa linha administrativa prega, por parte da gerência, o controle intenso do processo, do tempo e do ritmo de trabalho, deixando os trabalhadores, principalmente de execução, numa posição submissa e padronizada, com poucas possibilidades de criação, autonomia e participação nas decisões. O autoritarismo e a disciplina rígida são os alicerces dessa doutrina, similar a filosofia militar, que coadunava com a direção da empresa composta por militares até $2012^{27}$. A estrutura superior da empresa é composta por Departamentos e Centrais, onde os primeiros elaboram as políticas e as centrais executam, separam-se assim, os trabalhadores que "pensam", dos que "fazem".

Teixeira (2013) apresenta casos, relatados por funcionários da empresa, que exemplificam as práticas autoritárias nas relações de trabalho nos Correios no contexto da ditadura militar e utilização dos próprios funcionários nos serviços de informação:

\footnotetext{
${ }^{26}$ No período de novembro de 1971 a setembro de 1977 a ECT recebeu quatro missões de técnicos franceses especializados em correios. Essas missões trabalharam na organização da área postal, isto é, no setor de correspondências, impresso e encomendas.

${ }^{27}$ Militares ocuparam funções estratégicas na empresa desde 1967, o último foi o Major Brigadeiro do Ar José Eduardo Xavier que ocupou a Vice-Presidência de Operações (VIOPE) até setembro de 2012; Ata da $4^{\mathrm{a}}$ REDIR, 19/09/2012.
} 
Relato 1: Assim que os militares assumiram os correios a coisa ficou preta. Todo mundo tinha que trabalhar mesmo, não se tolerava mais atrasos, era muita pressão. Eu era um funcionário que tomava conta dos colegas lá na Vila Mariana, um cargo informal. De repente, um dia, o coronel me chama e mais todos aqueles que por algum motivo foram indicados como de confiança. Ele nos reuniu e disse que agora éramos monitores, que íamos tomar conta mesmo dos colegas de verdade, que tudo de errado tinha que ser informado. Eu pedi licença e falei que não queria, que preferia continuar a entregar cartas. $\mathrm{O}$ coronel disse, na frente de todo mundo, gritando, que quem manda agora sou eu, você só obedece e vai fazer o que eu estou mandando seu FDP! Fiquei com vergonha e medo de ser preso ou alguma coisa parecida, mas aí tudo começou a melhorar, recebi aumento já no mês seguinte, depois fui fazer curso de supervisor, tudo ficou muito melhor do que era. Depois daquele dia nunca mais tive coragem de falar nada! [...]

Relato 2: Teve uma vez, acho que era final de 79, que prometeram para nós um aumento que não veio, aí o pessoal resolveu fazer um abaixo assinado questionando a empresa sobre o tal aumento e mandamos para a GAP [na época era a Gerência de Administração de Pessoal]. Três dias depois todo mundo do setor foi mandado embora (BARROS NETO, 2004, p.71).

Teixeira (2013, p.43) ao analisar a organização do trabalho no contexto da ditadura militar nos Correios, descreve as ações com a lógica militar que foram implantadas e nesse contexto, as intervenções gerenciais tiveram como objetivo a adoção de métodos de gestão focados no controle, disciplina e racionalização da força de trabalho. A criação de funções como o supervisor operacional, encarregado de fiscalizar o trabalho no interior das unidades operacionais, como o serviço dos carteiros e operadores de triagem e transbordo (OTT) dentro dos Centros de Distribuição Domiciliária (CDD), e mesmo o trabalho externo de distribuição de objetos postais.

À inspetoria regional coube o papel de censor e "conselheiro", já que deveria
verificar os procedimentos de execução do trabalho e, ao mesmo tempo,
propor mudanças, informar, "aconselhar" os gestores de unidades
operacionais para que cumprissem as normas estabelecidas da forma mais
conveniente e conforme o prescrito, além de mostrarem como realizar tais
procedimentos. Passou-se à responsabilidade da inspetoria também a
fiscalização do trabalho dos chefes de unidades operacionais a fim de verificar
se eles desempenhavam suas funções de forma satisfatória, ou seja, se estavam
cumprindo as decisões elaboradas pelas equipes dos departamentos de
concepção da empresa, além de verificar assuntos relacionados a problemas
financeiros, materiais, sindicâncias e problemas com correspondências (como,
por exemplo, investigar atrasos e violações de correspondências).
(TEIXEIRA, 2013, p.47/48)

As ações de autoritarismo e repressão, segundo Teixeira (2013, p.58), foram uma constante durante décadas na empresa consolidando práticas de segredo e silêncio no interior da estatal, cristalizando a cultura do sigilo. 


\subsection{O Acesso à Informação}

\subsubsection{A Ciência da Informação e o Compromisso Social}

A origem histórica da Ciência da Informação tem na Bibliografia e na Documentação suas bases. As atividades dos documentalistas foram se desenvolvendo simultaneamente ao surgimento das bibliotecas públicas. O encontro de Paul Otlet e La Fontaine, em Bruxelas, em 1892, é considerado um marco nesse processo evolutivo. A criação do Instituto Internacional de Bibliografia (IIB), em 1895; sua transformação em 1931, em Instituto Internacional de Documentação, depois em 1938 em Federação Internacional de Documentação (FID) demonstram o quanto foi profícuo o início do século XX para o universo da informação. Essa movimentação tem claras relações com os avanços e transformações científicas e sociais na época. O período iniciado no século XIX, e muitas vezes esticado até a Primeira Guerra Mundial, foi sem dúvida, o século da Revolução Industrial inglesa, de sua difusão, de sua hegemonia e, ao mesmo tempo, de sua superação por outros processos socioeconômicos de igual magnitude, que ocorreram em outras formações sociais, na Europa e fora dela. (CURY, 2006, p. 16). Da Revolução Francesa à Revolução Industrial, foram muitas as mudanças na sociedade europeia e americana, com reflexos em todo mundo ocidental, com o protagonismo das novas ideias oriundas do Iluminismo.

A Ciência da Informação surge então, a partir da metade do século XX, com sua consolidação na década de 1960 (ARAÚJO, 2014, p.105), no bojo das conquistas sociais na sociedade moderna, em que ideais como liberdade, o feminismo, a revolução comportamental

e uma maior participação social eram ideais dominantes. É neste cenário que começa o processo de institucionalização da Ciência da Informação como ciência.

A Ciência da Informação tem características próprias que estão inseridas nos questionamentos sobre o tipo de ciência que ela pretende ser. Consenso para a maioria dos pesquisadores (ARAÚJO, 2014, p.105), a Ciência da Informação nasce em meados do século XX, no pós-guerra, no bojo das transformações das sociedades contemporâneas, onde a comunicação, o uso da linguagem, dos sistemas, do conhecimento como objetos de pesquisa passou a ser determinante. Uma das questões presente nas várias contribuições é a busca por uma definição da Ciência da Informação. 
Um primeiro aspecto é o seu reconhecimento como ciência. A ciência está relacionada com a CI sob dois aspectos: (a) como algo que a CI é ou pretende ser; (b) como algo que ela procura explicar, e talvez até mesmo transformar. O primeiro aspecto, intrínseco, pressupõe uma epistemologia; o segundo, extrínseco, está presente nas ciências sociais. Para alguns, como Brookes (1980, p.125), a CI teórica mal existe e outros apresentam propostas para sua construção como ciência. Muitos problemas associados ao conceito de ciência na CI provavelmente nascem da incapacidade de conciliar e sustentar esses dois aspectos.

$\mathrm{Na}$ discussão científica supõe-se que o interesse reside na busca da verdade e no progresso da ciência. Entretanto, nos remetemos a Gramsci $(1979$, p.97) onde a ciência é uma categoria histórica, um movimento em constante evolução e que toda a ciência está ligada às necessidades, à vida, à atividade do homem.

Se as verdades científicas fossem definitivas, a ciência teria deixado de existir
como tal, como investigação, como nova experimentação, e a atividade
científica reduzir-se-ia a uma divulgação do já descoberto. E isto, é claro, por
sorte da ciência, não é verdade. Mas se as verdades científicas nem sequer são
definitivas e peremptórias, a ciência é uma categoria histórica, um movimento
em constante evolução[...]
[...] Se assim é efetivamente, o que interessa à ciência não é tanto a
objetividade do real como o homem que elabora os seus métodos de
investigação, que retifica continuamente os seus instrumentos materiais que
reforçam os órgãos sensoriais e os instrumentos lógicos (incluindo as
matemáticas) de discriminação e verificação, quer dizer, a cultura, a
concepção de Mundo, a relação entre o homem e a realidade com a mediação
da tecnologia. Procurar a realidade fora dos homens, quer dizer, entendê-la no
sentido religioso ou metafísico, revela-se mesmo na ciência como um
paradoxo. Sem o homem, que significaria a realidade do universo? Toda
ciência está ligada às necessidades, à vida, à atividade do homem.
(GRAMSCI, 1979, p.97/98)

Neste sentido entendemos a Ciência da Informação como uma ciência que tem, portanto, que refletir como deve ser sua interação com a sociedade e o seu consequente compromisso social.

Discutir esse compromisso social da CI significa sermos capazes de avaliar a sua inserção, como ciência na sociedade e apontarmos em que direção ela tem caminhado: para a transformação das condições de vida? Para a manutenção? Para contribuir para este debate, pretendemos responder: Como essa intervenção "demonstra compromisso social"? Por que é importante para a CI, enquanto ciência, buscar uma produção e uma intervenção que denote “compromisso social"?

Mandel (1982, p.123) afirma que toda a teoria do conhecimento é submetida a uma prova implacável: a prova da prática. Em última análise, o próprio conhecimento não é um 
fenômeno separado da vida e dos interesses dos homens. É uma arma para a conservação da espécie, uma arma que permite ao homem dominar as forças da natureza, uma arma para compreender (mais tarde) as origens da "questão social" e os meios de as resolver. O conhecimento nasceu da prática social do homem; tem por função aperfeiçoar esta prática. A sua eficácia mede-se, em última análise, pelos seus efeitos práticos. A verificação prática permanece a melhor arma de última instância contra os sofistas e os céticos $^{28}$. Segundo $\mathrm{Mandel}^{29}$, muito frequentemente, a eficácia prática, o caráter "verdadeiro" ou "falso" de uma hipótese científica não aparecem imediatamente. É preciso tempo, um certo recuo, novas experiências, uma série de sucessivas "provas práticas", antes que o caráter científico de uma teoria se imponha efetivamente na prática. No fim, os fatos acabam por confirmar qual teoria foi realmente científica, capaz de apreender o real em todas as suas contradições, todo o seu movimento de conjunto, e quais hipóteses se encontram erradas, ou seja, capazes de apreender somente parte do real, isolando-os da totalidade estruturada, e por isso incapazes de apreender o movimento a longo prazo na sua dialética fundamental.

A Ciência da Informação vem se constituindo como prática social dos homens ao interagir com diversas áreas do conhecimento e campo consagrado de interdisciplinaridade. Os avanços sejam sociais, tecnológicos, econômicos têm produzido insumos que fazem da Ciência da Informação uma ciência em constante movimento e experiências práticas que estão intrinsecamente vinculadas às necessidades sociais confirmando seu caráter científico e social.

O compromisso seria uma palavra oca, uma abstração, se não envolvesse a decisão lúcida e profunda de quem o assume. Se não se desse no plano do concreto. Freire (1983, p.16) afirma que a primeira condição para que um ser possa assumir um ato comprometido está em ser capaz de agir e refletir. Para que a Ciência da Informação esteja comprometida, há necessidade de que sua produção esteja vinculada com a ação e a reflexão. Esta reflexão, sobre si mesmo, sobre seu estar no mundo, associada indissoluvelmente à sua ação sobre o mundo, é o que possibilita transpor os limites que lhe são impostos pelo próprio mundo. Somente a capacidade de "sair de seu contexto, de "distanciar-se" dele para ficar com ele; capaz de admirálo para, objetivando-o, transformá-lo e, transformando-o, saber-se transformado pela sua própria criação" (Ibid., p.17) se é capaz de comprometer-se.

\footnotetext{
${ }^{28}$ Os sofistas foram os primeiros filósofos do período socrático, substituíram a natureza que antes era o principal objeto de reflexão pela arte da persuasão. O Ceticismo filosófico originou-se a partir da filosofia grega, procura saber, não se contentando com a ignorância, por meio da dúvida. Opõem-se ao dogmatismo, em que é impossível conhecer a verdade.

${ }^{29}$ Mandel, op. cit., p. 85
} 
A CI precisa olhar o todo em que está inserida como ciência e ser capaz de vislumbrar as mudanças tecnológicas, sociais, ambientais, políticas para refletir - se distanciando, mas inserida - com a visão no novo, agir para transformá-lo.

Assim, parafraseando Freire, como não há homem sem mundo, nem mundo sem homem, não pode haver reflexão e ação fora da relação homem-realidade. Na medida em que o compromisso não pode ser um ato passivo, mas práxis, ação e reflexão sobre a realidade - o compromisso implica indubitavelmente um conhecimento da realidade. Para Freire (1983), se o compromisso só é válido quando está carregado de humanismo, este por sua vez, só é consequente quando está fundado cientificamente. Assim, podemos inferir na evolução da Ciência da Informação como ciência, seu compromisso social.

Borko (1968) foi um dos primeiros a nos ajudar na conceituação do que é Ciência da Informação, e o que faz um cientista da informação. Define a Ciência da Informação como a disciplina que investiga as propriedades e o comportamento da informação, as forças que governam a tramitação da informação, e o significado da informação processada para um ideal de acessibilidade e usabilidade. Ou seja, se preocupa com o que se relaciona com a origem, coleta, organização, arquivo, recuperação, interpretação, transformação e utilização da informação. Outro aspecto bem destacado pelo autor é a interdisciplinaridade desta ciência e que veremos presente em várias outras definições. Ao identificar os objetivos da Ciência da Informação "para um ideal de acessibilidade e usabilidade" destaca sua finalidade social, pois o acesso e uso da informação é uma atividade da sociedade, fortalecendo assim o compromisso social da nascente CI.

Wersig e Neveling introduzem mais explicitamente a responsabilidade social como fundamento da CI que nos anos 70 passa a ser um campo de estudo decisivo para o crescimento e desenvolvimento das empresas " [...] atualmente, transmitir o conhecimento para aqueles que dele necessitam é uma responsabilidade social, e essa responsabilidade social parece ser o verdadeiro fundamento da CI" (WERSIG; NEVELLING,1975, p.11). Numa perspectiva de desenvolvimento histórico Wersig e Nevelling (Ibid. p.11) discutem as várias definições explícitas e implícitas de informação e da Ciência da Informação e apresentam uma proposta de definição de CI baseada na necessidade social.

Esta ciência é baseada na noção das necessidades de informação de certas pessoas envolvidas em trabalho social, e relacionadas com o estudo de métodos de organização dos processos de comunicação numa forma que atenda estas necessidades de informação. $O$ termo básico 'informação' pode ser entendido somente se definido em relação à estas necessidades de informação: tanto, redução da incerteza causada por danos comunicados quanto como dados usados para reduzir incerteza. (WERSIG; NEVELLING,1975, p.17) 
Os autores identificam a CI relacionada com a organização dos processos de comunicação destinados à informação para uma determinada clientela, ou seja, não propõem uma compreensão limitada de informação, mas da área em que a informação é considerada, portanto baseada em problemas práticos que devem ser resolvidos. Uma abordagem orientada para o fenômeno da informação. Listam as várias áreas que interagem no mundo da CI, e as chamam todas de Ciência da Informação: biblioteconomia, museologia, arquivologia, educação, assim como, psicologia, sociologia, economia, ciência política e tecnologia que se concentram no estudo dos processos de informação - processos de comunicação destinados à redução de incertezas. Neste sentido consideram que como campo científico, a partir destas disciplinas, poderia ser entendido como uma Teoria Geral da Informação, mas destacam a importância de, nas discussões teóricas sobre CI, identificar se o que está sendo discutindo são os fenômenos, características ou métodos da CI, das Ciências da Informação ou da Teoria Geral da Informação.

Para nos auxiliar com conceitos de informação, mas não com definições, Belkin (1978) estabelece um paradigma em que o fenômeno central é a informação e considera que nenhum dos conceitos de informação pesquisados tenha provado ser útil na discussão para o significado de um conceito de informação. Entretanto, acredita que alguns deles, pelo menos, têm potencial para se tornar útil, mas esse potencial só poderá ser realizado se esses conceitos forem desenvolvidos para remediar as suas fraquezas e, mais importante, se eles forem realmente aplicados a problemas específicos no âmbito da Ciência da Informação. Como importante tentativa para resolver o que chama de problema da CI, sugere tentar entender as bases teóricas implícitas na recuperação da informação, uma vez que acredita que, muitas vezes os usuários de sistemas de busca não são capazes de formular precisamente o que eles precisam. A falta de algum conhecimento vital para formular suas consultas os impede de obter as informações que realmente desejam. Por este motivo o estudo dos usuários tem significado importante. Portanto, ambas as pontas de qualquer sistema de comunicação interessam à Ciência da Informação, uma vez que ocorrem processos cognitivos que são significantes para a CI. Aqui temos a relevância dos usuários, ao mesmo nível dos sistemas e dos processos, e isso nada mais é do que estreitar as relações com a sociedade, do que desenvolver a CI com compromisso social.

Saracevic (1996) nos leva a explorar a evolução e a natureza da ciência da informação e destaca as modificações apontadas por Wersig; Nevelling (1975) em que defendem a responsabilidade social como o verdadeiro fundamento da CI. Considera que a questão da recuperação da informação e o crescente uso da tecnologia desloca o debate para uma 
contextualização mais ampla voltando-se para o usuário e suas interações, em que Popper é citado também ao discutir os princípios da recuperação da informação e a necessidade de se construir uma Teoria da Ciência da Informação.

Em meados da década de 1970 vários autores apresentam um reconhecimento de que a base da Ciência da Informação estava ligada aos processos de comunicação humana. Belkin e Robertson resumem "o propósito da CI é facilitar a comunicação de informações entre seres humanos" (BELKIN, 1978 apud BELKIN; ROBERTSON, 1976).

Já nos anos 80, Saracevic (1996) destaca a ligação da administração como um elo básico na Ciência da Informação ao citar que na literatura do período a American Society for Information Science (ASIS) definiu como “(A) organização profissional para aqueles envolvidos com o desenho, a administração e o uso de sistemas e tecnologias de informação." Assim, Saracevic define Ciência da Informação a partir de uma evolução e um enfoque que chama contemporâneo (1990):

A CIÊNCIA DA INFORMAÇÃO é um campo dedicado às questões científicas e à prática profissional voltadas para os problemas da efetiva comunicação do conhecimento e de seus registros entre os seres humanos, no contexto social, institucional ou individual do uso e das necessidades de informação. No tratamento destas questões são consideradas de particular interesse as vantagens das modernas tecnologias informacionais (SARACEVIC, 1996, p.47)

A Ciência da Informação, a partir dos pesquisadores analisados, e seus vários pontos de vistas, reforçam nossa concepção enquanto ciência que deve ter seu foco nas relações sociais, nas necessidades sociais e na interação entre seres humanos. A ideia inicial de que a CI era uma ciência dedicada à informação em ciência e tecnologia (ARAÚJO, 2014, p.105), evoluiu para uma ciência voltada para a resolução dos vários problemas causados justamente pelas ciências modernas, uma ciência pós-moderna (Ibid., p.120).

Neste sentido, a CI está em constante ação e reflexão, em transformação, se caracteriza como ciência humana e social e se institucionalizou como ciências sociais aplicadas. Como ciência humana e social tem um compromisso radical com o homem concreto que deve se orientar no sentido de transformação de qualquer situação objetiva na qual o homem concreto esteja sendo impedido de ser mais (FREIRE, 1983). A Ciência da Informação é uma ciência social com compromisso social. 


\subsubsection{A Transparência Pública e o Acesso à Informação}

A transparência pública corresponde ao compromisso que estabelece um órgão governamental para possibilitar ao público o acesso à informação existente sobre um assunto público. Esta informação pode se apresentar de muitas formas diferentes e referir-se à aspectos diferentes de como a organização está tratando os assuntos públicos.

Rodrigues (2013, p.424) nos remete aos anos 1970 quando surge o conceito de transparência, observando que seu sentido político é decorrente do questionamento do modelo de administração tradicional ancorado na cultura do segredo, e que sua noção já está presente como premissa para o bom funcionamento da Administração Pública. A transparência, como forma e modalidade de comunicação entre o estado e o cidadão, não era uma exigência na administração pública brasileira até o final da década de 1980 quando da promulgação da CF.

Jardim (1999, p.49) destaca que a noção de transparência administrativa, em uma de suas leituras, é requisito de controle da sociedade civil sobre o Estado. A transparência do Estado se expressa na possibilidade de acesso do cidadão à informação governamental como requisito fundamental. A opacidade informacional do Estado é a expressão e o mecanismo de produção de hegemonia da classe dirigente, instrumento de dominação e exclusão social. O autor ao evidenciar a apropriação privada do Estado, nos auxilia na discussão sobre o conceito que envolve os Correios enquanto empresa pública de direito privado e a transparência de suas informações.

No Brasil, a captura do Estado, privatizando-o por instrumentos escusos, significa o inverso da estatização da sociedade e consequente penalização sistemática dos desorganizados e excluídos. Este monopólio informacional tem sido acentuadamente "privatizado", apesar de sua natureza pública, além de insuficientemente publicizado. (JARDIM, 1999, p.198)

Zepeda (2012, p.9) destaca que a transparência se converteu em um valor fundamental nas democracias de nossa época, e critica o discurso liberal sobre a transparência e a sociedade aberta, que tem o defeito de minimizar as possibilidades de ação e reformas sociais dos Estados democráticos pela via da ação pública.

No Brasil, o inciso XXXIII do artigo $5^{\circ}$, do Capítulo I - Dos Direitos e Deveres Individuais e Coletivos, do Título II - Dos Direitos e Garantias Fundamentais, da Constituição Federal garante a todos os brasileiros e estrangeiros residentes no país o direito a receber dos órgãos públicos informações de seu interesse particular, ou de interesse coletivo ou geral. 
Art. $5^{\circ}$ Todos são iguais perante a lei, sem distinção de qualquer natureza, garantindo-se aos brasileiros e aos estrangeiros residentes no País a inviolabilidade do direito à vida, à liberdade, à igualdade, à segurança e à propriedade, nos termos seguintes:

$[\ldots$.

XXXIII - todos têm direito a receber dos órgãos públicos informações de seu interesse particular, ou de interesse coletivo ou geral, que serão prestadas no prazo da lei, sob pena de responsabilidade, ressalvadas aquelas cujo sigilo seja imprescindível à segurança da sociedade e do Estado;(BRASIL, 1988)

A CF delimita o papel a ser ocupado pelo Estado e aquele destinado aos sujeitos privados. E essa distinção possui uma função dogmática extremamente importante: ele é o critério que distingue a incidência das normas de direito público das de direito privado. As atividades estatais e as atividades privadas possuem, portanto regime jurídicos diferentes. A separação entre administração direta e indireta trouxe uma mudança no conceito de serviço público como apontado por Barroso (2000, p.202/203) quando tratamos do Estado brasileiro e as estatais, entretanto esse conceito não é um consenso, inclusive no âmbito jurídico, como veremos em recentes decisões do STF.

Jardim (1999, p.199) constata que, para o modelo de Estado em vigor no Brasil, a opacidade informacional pode não representar um obstáculo aos que dominam, mas sim para os dominados. Desta forma, uma gestão da informação não seria fundamental para o controle do Estado pelas classes dirigentes, dando como exemplo a lógica privada e pessoal no processo político-decisório, que prevalece até os dias de hoje.

Zorzal (2015, p.62) após análise de vários autores destacou a existência, na literatura, de diversas definições para o termo transparência, com variados graus de especificidade, dependendo do contexto. A autora apresenta, em sua pesquisa, um trabalho que demonstra o conceito de transparência pública após abordagem de seis autores, com uma afirmação em sua conclusão.

[...] transparência pública é a divulgação e acesso a informações econômicas, sociais e políticas relevantes, referentes ao governo e/ou às suas instituições, direcionadas ao cidadão, que o capacitem para participar das decisões políticas e permitam que ele avalie o governo e/ou suas instituições (ZORZAL, 2015, p.62 apud PESSOA, 2013, p.27)

Zorzal cita ainda outros autores que concluíram que o primeiro estudo a fazer uso da palavra transparência, com o sentido atual, data de 1962, quando o economista dinamarquês Knud Erik Svendsen a utilizou em conexão com o problema de transparência em 
macroeconomia (ZORZAL, 2015, p.62 apud MICHENER; BERSCH, 2011). Segundo a autora, o termo transparência acabou assumindo novos significados e popularidade nas duas últimas décadas, com o debate sobre as boas práticas de governança corporativa relacionadas ao modo como as empresas são administradas e controladas.

O direito de acesso à informação aparece no âmbito da defesa à liberdade de expressão que pressupõe o acesso a fontes íntegras e plurais de informação (CUNHA FILHO; XAVIER, 2014, p13). Os autores destacam que diversos organismos internacionais reconhecem a associação entre liberdade de expressão e o direito de obter informações públicas, como a Corte Europeia de Direitos Humanos.

Como tratado no capítulo 2, Bourdieu trata o Estado como monopólio da violência física e simbólica, que controla os cidadãos. Bobbio (2015, p.47) apresenta uma pergunta clássica da filosofia política: "quem vigia o vigilante/quem cuida do cuidador?", trazendo o Panóptico 30 de Betham ${ }^{31}$, que Foucault definiu como máquina para dissociar a dupla "ver-ser-visto", aplicado ao Estado, onde o cidadão continuamente sob vigilância de um personagem que nada sabem, nem sequer se existe. $\mathrm{O}$ autor considera que o direito de acesso à informação é uma das tantas formas do direito que um Estado democrático reconhece aos cidadãos de vigiar os vigilantes.

Oliveira (2013, p.3/4) discute também alguns aspectos da democratização da informação e sua interface com a CI abordando questões éticas e ciência. Mudanças substanciais na economia, na política e na própria sociedade são provados pelo rompimento de fronteiras que o processo da globalização provoca. A autora parte da premissa de que a informação é um fenômeno social, entendendo assim os processos que a envolvem e requisitam um estatuto que seja "permeado por um conjunto de padrões éticos, sobretudo quando se discute a democratização e o acesso aos conteúdos informacionais".

Cunha Filho e Xavier (2014, p.13) destacam que no Brasil a obrigação de estabelecer mecanismos de transparência ativa precede a LAI e cita a Lei Complementar $n^{\circ}$ 103/2009 (LC103), que altera a Lei Complementar $n^{\circ}$ 101/2000 (LC101), que trata das finanças públicas voltadas para a responsabilidade na gestão fiscal. A LC101 determina a "ampla divulgação,

\footnotetext{
${ }^{30}$ Pan-óptico ou Panóptico - Criado por Benthan, em 1785, é um sistema de Observação Total com celas vazadas, onde o controle é exclusivo do observador que no centro vê todas as celas, mas os prisioneiros não veem os observadores. Otimização de vigilância e economia

${ }^{31}$ Jeremy Benthan (1748 - 1832) - filósofo e jurista inglês, difusor do Utilitarismo, considerava que o direito penal era um ramo crucial do direito, devido a sua particularidade na abordagem da psicologia humana e com isso ideias de que com penas bem calculadas, a experiência solitária nas prisões evitaria as delinquências;
} 
inclusive em meios eletrônicos de acesso público" e a transparência assegurada ao incentivo à participação popular e realização de audiências públicas, também presente na LAI. A LC103, explicita a transparência da gestão e assegura mediante o inciso II do art. 48 "liberação ao pleno conhecimento e acompanhamento da sociedade, em tempo real, de informações pormenorizadas sobre a execução orçamentária e financeira, em meios eletrônicos de acesso público". Esse dispositivo, segundo os autores, levou os Poderes Públicos brasileiros a criar portais da transparência, disponibilizando assim informações sobre suas despesas, receitas, convênios, dentre outras.

Jardim (1999, p.57) reforça a importância dos temas como accountability e ombudsmam na relação dos debates teóricos e das políticas de transparência no mundo anglo-saxão e escandinavo. $\mathrm{O}$ autor apresenta dois instrumentos que ajudariam a reduzir a desiquilíbrio da informação: as Organizações Não Governamentais (ONG) e os ombudsmam, assim como, identifica a associação da transparência à outras duas dimensões: a comunicação e a publicidade.

A efetividade dos mecanismos de accountability dependeria do grau de acesso do cidadão à informação governamental. A indisponibilidade de informações sobre as ações e responsabilidade de governo implicaria na produção de um déficit de accountability. Cabe, portanto, ao Estado, produzir meios que estimulem os governantes a, publicamente, justificarem o curso de suas ações, relacionando as políticas adotadas com os efeitos que produzem ou esperam produzir (JARDIM, 1999, p. 57).

A Open Knowledge Internacional no Brasil (OKBR), também chamada de Rede pelo Conhecimento Livre, é uma Organização da Sociedade Civil (OSC) e se define como "sem fins lucrativos e apartidária" (Open Knowledge Internacional, 2015), iniciou suas atividades no país em final de 2013. A Organização publica o Índice Global de Dados Abertos como uma colaboração da sociedade civil mapeando o estado dos dados abertos nos países e lugares do mundo, conforme informa em sua página na internet. Em 2015, publicou seu Índice Global de Dados Abertos 2015 (2015 Global Open Data Index). Este índice faz um ranking dos países com base na disponibilidade a acessibilidade aos dados, analisando categorias essenciais como: gastos governamentais, resultados de eleições, compras públicas, níveis de poluição, conjunto de dados de localização, entre outros. O Brasil passou de $26^{\circ}$ lugar e ocupa, em 2015 , o $12^{\circ}$ lugar nesta classificação. Entretanto, a organização destaca que dados de empresas e de códigos postais (CEP) não estão disponíveis seguindo os critérios do levantamento. 
Algumas das mais importantes conclusões do Índice Global de Dados Abertos são as seguintes:

-Em 2015, o Brasil melhorou sua posição no ranking, passando de $26^{\circ}$ para $12^{\circ}$. Alguns novos conjuntos de dados passaram a ser contabilizados, como resultados das eleições, qualidade da água e compras públicas, o que ajudou o país a melhorar na comparação. No entanto, dados de empresas e de códigos postais (CEP) ainda precisam melhorar muito, os últimos ainda não disponíveis seguindo os critérios do levantamento.

-Na América Latina, estão melhor posicionados Colômbia $\left(4^{\circ}\right)$ e Uruguai $\left(7^{\circ}\right)$. O Uruguai foi o primeiro país a organizar encontros regionais sobre dados abertos, a Abrelatam e Condatos, em 2014, e ano que vem esses eventos ocorrerão na Colômbia. O Brasil ainda não organizou um encontro regional sobre o tema.[...] (Open Knowledge Internacional, 2015, grifo da autora)

A Open Knowldge Internacional (OKI) define dados abertos como sendo "informações que podem ser livremente utilizadas, reutilizadas e compartilhadas por qualquer um, em qualquer lugar, para qualquer propósito" (OKBR, 2015). Para serem dados verdadeiramente abertos a organização entende que devem requer uma variedade tanto de habilidades técnicas e legais que asseguram que qualquer um pode reutilizá-los livremente, para máximo benefício, e o Índice Global de Dados Abertos avalia esta condição. Segundo eles, a "Definição de Aberto" (Open Definition) estabelece os princípios que definem "abertura" em relação a dados e conteúdo. Assim como outras organizações não governamentais, a OKBR conseguiu o apoio da Open Society Foudations ${ }^{32}$ para estruturar a governança da Organização e auxiliar a definição de seu planejamento estratégico (Relatório de Atividades 2014/OKBR, 2015).

Ghani (2016), apresenta uma opinião sobre o interesse de George Soros na política de transparência pública, e outras pautas consideradas de esquerda, como sendo sua ação a favor do Globalismo ${ }^{33}$, que interessa à grandes famílias bilionárias. Um fenômeno muito discutido pelo mundo a fora, segundo o autor, mas pouco conhecido no Brasil. Portanto, esta é uma discussão sobre os usos e interesses da transparência pública, que precisa ser melhor estudada e analisada no Brasil, para que a sociedade brasileira tenha de fato o controle social das informações produzidas pelo Estado brasileiro, e que as mesmas não sejam usada contra o Estado Democrático de Direito.

\footnotetext{
${ }^{32}$ A Open Society Foudations é uma fundação sem fins lucrativos, com base em Nova York, Estados Unidos da América, criada pelo empresário bilionário e megaespeculador George Soros.

${ }^{33}$ Segundo Beck o Globalismo seria a ditadura neoliberal do mercado mundial que destrói os alicerces do desenvolvimento democrático (BECK, Ulrich. Liberdade ou Capitalismo. Ulrich Beck conversa com Johannes Willms. São Paulo: UNESP, 2003. P.23)
} 
Figura 2 - Ranking Dados Abertos 2015

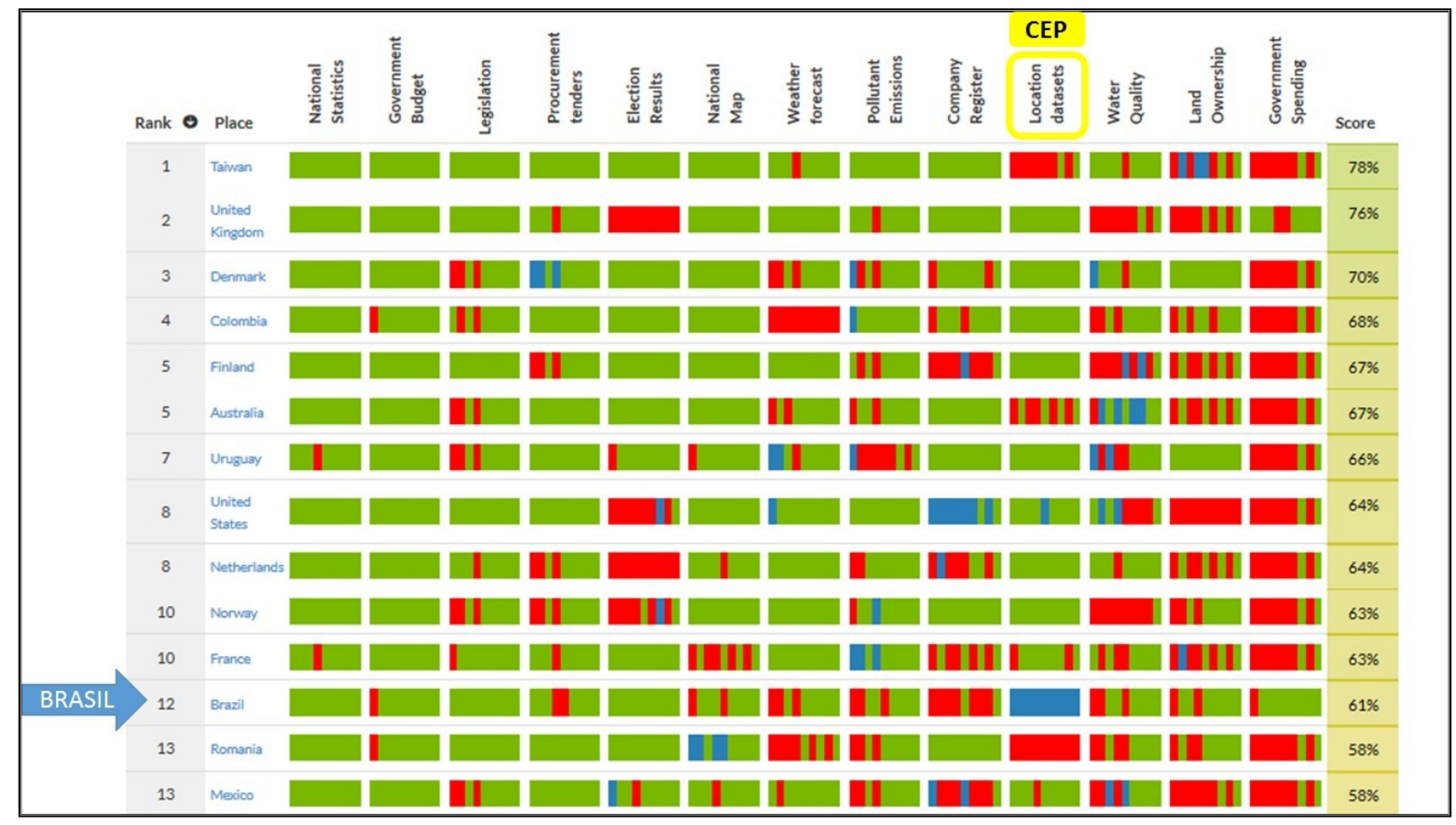

Fonte: elaborado pela autora com base no 2015 Global Open Data Index ${ }^{34}$

Com relação ao ranking acima, verificamos como a não liberação do CEP, enquanto Dados Abertos, interfere na posição do Brasil na classificação mundial, sendo o único item marcado em azul no país, ou seja, "pouco claro". Isso se deve ao fato do CEP ser acessado individualmente na página dos Correios, o que permite um acesso limitado, o que veremos mais adiante nesta pesquisa.

A compreensão da transparência das informações públicas vem se ampliando a cada dia na sociedade brasileira. Entretanto, o que pouco se discute é o conceito de informação pública.

Frohmann (2008, p.20) destaca a importância em conciliar o conceito de informação, com os estudos de importantes práticas, públicas e sociais, com o conceito de materialidade. $\mathrm{O}$ autor afirma que o conceito de materialidade é muito importante quando pesquisamos o que fazem os "sistemas de informação", entendendo-os no sentido amplo o que ele chama de regimes de informação ${ }^{35}$. O conceito de materialidade, para Frohmann $(2008$, p.21) traz um

\footnotetext{
${ }^{34}$ O mapa deve ser lido com as variações das cores onde o vermelho representa "não disponível", o verde "disponível”, e o azul representa que está "pouco claro" se a informação está aberta, ou disponível.

${ }^{35}$ Frohmann (1995) introduz o conceito de regime de informação - qualquer sistema ou rede que permite o fluxo de informação, através de estruturas específicas, de canais e produtores a consumidores, e este conceito passa a ser entendido como um elemento passível de ser utilizado como ponto de partida para a elaboração de políticas nacionais de informação.
} 
entendimento valioso do caráter público e social da informação em nosso tempo, e neste sentido é necessário "falar sobre documentos". Para o autor, "documento" nomeia a materialidade da informação.

[...] se "documento" nomeia a materialidade da informação, e se a materialidade é importante para o entendimento dos aspectos públicos e sociais da informação, então os estudos da documentação tornam-se importantes para os estudos da informação. A documentação se torna o meio de materialização da informação. Estudar a documentação é estudar as consequências e os efeitos da materialidade da informação. (FROHMANN, 2008, p.21/22)

Frohmann (2008) ressalta que para Foucault enunciados não são documentos, mas são úteis para a reflexão sobre documentos, e desta maneira, sobre a materialidade da informação, uma vez que o analisa sob o ponto de vista da sua existência (como surge, as regras de sua transformação, ampliação, as conexões entre enunciados, e seu desvanecimento até deixar de existir), e não ao que ele representa ou significa. "[...]para uma sequência de elementos linguísticos ser considerada e analisada como um enunciado [...] ela deve ter uma existência material" (FROHMANN, 2008, p.21/22 apud FOUCAULT, 2005). Outro aspecto importante é a distinção entre a fisicalidade e a materialidade, onde esta última é medida pela massa, inércia e resistência. Com isso, o autor considera que o conceito de materialidade está mais próximo ao de massa da física moderna, do que de substância física, e justifica a analogia porque "os enunciados apresentam graus de estabilidade, de acomodação e de resistência à transformação, deteriorização ou desestabilização. Sua massa responde pela energia de seu poder de afetar, ou seja, o poder de criar efeitos" (FROHMANN. 2008, p.22). Assim, o autor explicita que diferentes meios pelos quais enunciados se estabilizam, se massificam e ganham poder, sendo fundamental, então especificar as fontes de massa, energia e força dos enunciados.

Segundo Frohmann (2008, p.22), Foucault diz que a materialidade do enunciado pode ser analisada pelo grau de sua imersão institucional, ou seja, as rotinas institucionalizadas estabelecem e mantêm as relações entre enunciados, dando a eles "peso, massa, inércia e resistência". Para o autor, os documentos que circulam através e dentre as instituições têm uma materialidade que se destaca, uma vez que requerem esforço para produzi-los, instituir práticas com eles, substituí-los por diferentes documentos, e instalar documentos manufaturados e disponibilizados por uma instituição em outra. Frohmann (2008) se propõe a aplicar o que Foucault fala sobre os enunciados ao estudo da documentação, e destaca o fato de Foucault atribuir maior significado ao papel da documentação do que a comunicação da informação, pelo "poder da escrita". 
O "poder da escrita" que "captura e fixa" indivíduos não é o poder de apenas transcrever características objetivas individuais pré-existentes na forma escrita, portanto permitindo que "informações" sobre os indivíduos fossem comunicadas. Ao contrário, o poder da escrita é "uma parte essencial dos mecanismos da disciplina" ou o aparelho disciplinar através do qual indivíduos são construídos como objetos de conhecimento. Assim, interesse de Foucault não é a documentação como meio de comunicação de informação, mas como transmissão de poder gerativo e formativo, através do qual indivíduos que podem ser conhecidos são constituídos institucionalmente. (FROHMANN. 2008, p.25)

A informação, portanto, segundo o autor, se materializa através da documentação e assim passa a ter um caráter público e social. Esta materialização não apenas por meios institucionais, mas também por meios tecnológicos. Frohmann (2008, p.30) destaca ainda que a documentação digital desafia o cenário tradicional da disseminação da informação, marcada pela intencionalidade, possibilitando a comunicação entre indivíduos ou na troca de "informações" uns com os outros, sendo produzidas e processadas fora da consciência. Estes processos, muitas vezes não têm a ver com a comunicação de ideias, pensamentos, proposições, argumentos, evidências ou julgamentos. O autor atribui aos poderes emocionais dos fluxos dos documentos digitais, e com as reuniões nas quais seus poderes são exercidos.

GRICOLETO (2012, p.59/60) destaca a importância da discussão sobre informação e documento e a abordagem de Frohmann sobre o que é informação que fortalece a importância de organização da informação nos órgãos públicos.

Por este pensamento, achamos coerente retomar algumas abordagens de Frohmann que deslocou o foco do questionamento 'o que é informação? ' para 'como se constitui a impressão da informação?' e apontou a análise da reificação dos sentidos fornecidos historicamente pelas próprias práticas sociais com a organização material de formas documentais. Frohmann (2006) assinala que existe uma dupla materialidade do documento: seu engajamento institucional - passível de migração interinstitucional, como a relação textual entre a academia e o aparato jurídico - e a combinação entre enunciação e práticas sociais e públicas, por seu poder de gerar efeitos. Para o autor, o documento é $o$ fato, ou ainda, é $o$ ato - instituidor, institucionalizado, formal, legitimado. (GRIGOLETO, 2012, p.60 apud FREITAS, 2008)

Grigoleto ressalta que é por meio das palavras registradas em documentos institucionais que o passado pode ser reinventado; que memórias, objetos e elementos de uma sociedade podem ser preservados por meio de atos institucionais.

Neste sentido, um documento público para ser um fato, ou ainda, um ato precisa da chancela de pelo menos um agente público com autoridade para instituir, formalizar ou 
legitimar aquele ato, aquele documento. Esta é uma discussão atual quando cresce de forma ampla o uso de tecnologias digitais sem a devida institucionalização. Por exemplo, o uso do correio eletrônico nas tratativas entre servidores e entidades nos órgãos públicos, sem a devida assinatura eletrônica e, ultimamente, por meio de aplicativos de troca de texto instantânea onde chefias determinam ações.

Segundo Zepeda (2012, p.28) o conceito político de privacidade - o que é próprio do privado - significa "exclusão" ou "separação". O autor destaca que com o ascenso dos sistemas liberais durante o século XVII, o privado veio a significar tudo aquilo que não estava envolvido, ou definido pela esfera do aparato governamental. Dessa forma o privado chegou a ser definido em oposição às tarefas governamentais. Zepeda (2012) cita o filósofo alemão Jurgem Habermas pela precisão na origem destes conceitos.

Das Publikum, the public, le public, o público, opõem-se a 'privacidade', o 'poder público'. Os servidores do Estado são pessoas públicas, offentliche personen, public persons, personnes publiques; tem um cargo público, os negócios de seu ofício são públicos (public office, servisse publique), e públicos são chamados o edifício e estabelecimentos da autoridade. Do outro lado são as pessoas privadas...nos lugares privados. Confrontados com a autoridade, são os excluídos dos seus assuntos; que - diz-se - serve ao bem comum, que prossigam o seu lucro privado" (ZEPEDA, 2012, p. 28 apud HABERMAS, 1994, p.50, tradução livre da autora) ${ }^{36}$

Zepeda (2012, p.29) apresenta ainda que o sentido do privado supõe também que um conjunto de privados dão lugar a outra dimensão do público, que denominamos "o público", que não é governamental. O autor exemplifica no sentido que está presente na noção de "opinião pública", concebida como opinião que agrega os agentes privados, sem que essa condição de publicidade adquirida, nunca a torna opinião do Estado. Outro exemplo é na língua inglesa que "the public" equivale ao povo em geral. O autor reforça a necessidade de distinguir entre "o público", a soma de privados, opinião pública não governamental, e "no público", relativo ao Estado e suas normas, instituições e ações específicas.

Ao tratarmos da organização e acesso à informação nos Correios após a promulgação da LAI, estamos tratando da informação produzida pela empresa pública, pelo Estado, e é de

\footnotetext{
${ }^{36}$ Texto original: "Das Publikum, the public, le public, lo público, es, em contraposicion a la 'privacidad', el 'poder público'. Los servidores del Estado son personas públicas, offentliche personen, public persons, personnes publiques; tiene um oficio público, los negócios de su ofício son públicos (public office, servisse publique), y públicos se llama a los edificio y estabelecimentos de la autoridade. Del outro lado están la gente privada...los hogares privados. Enfrentados a la autoridade, están los súbditos excluídos de ella; aquella - se disse - sirve al bien común, estós persiguen su provecho privado"
} 
interesse público, assim como, informações que são públicas e não devem ser tratadas como de uso privativo do Estado.

A Lei de Arquivos no Brasil determina, no Capítulo II - Dos Arquivos Públicos, como identificar documentos públicos correntes, intermediários e permanentes $\left(\operatorname{art} .8^{\circ}\right)$; os procedimentos para eliminação de documentos por instituições públicas e de caráter público $\left(\operatorname{art.} 9^{\circ}\right)$; assim como que os documentos de valor permanente são inalienáveis e imprescritíveis $\left(\operatorname{art} .10^{\circ}\right)$. A gestão de documentos é definida como um conjunto de procedimentos e operações técnicas referentes à produção, tramitação, uso, avaliação e arquivamento de documentos em fase corrente e intermediária, visando sua eliminação ou recolhimento (Figura 2). Araújo Júnior, Souza e Albuquerque (2015, p. 45) afirmam que em termos de organização e gestão da informação, além do conhecimento das necessidades informacionais dos usuários, o pleno exercício do direito à informação se realizará com a organização dos documentos públicos e por isso a importância de trazer ao cenário do debate o conceito de gestão de documentos.

Para que a Transparência e o Acesso à Informação pública sejam garantidos é fundamental a organização da informação. Os autores destacam a importância das condições de organização da informação pública e as etapas que as necessidades informacionais que os profissionais, comprometidos com a organização e a gestão dos recursos informacionais, precisam analisar para compreenderem a dinâmica de uso da informação (ARAÚJO JÚNIOR; SOUZA; ALBUQUERQUE, 2015, p.45 apud Le Coadic, 2004). São enumeradas cinco etapas: identificação dos usuários e uso da informação; descrição do perfil dos usuários, bem como do seu ambiente de atuação; identificação das necessidades informacionais dos usuários; avaliação e contextualização das necessidades informacionais; e descrição e operacionalização das soluções relativas ao atendimento das demandas e necessidades informacionais dos usuários.

No processo de gestão documental, é fundamental a avaliação de documentos para determinar os prazos de guarda e destinação que é realizada de acordo com os valores que lhe são atribuídos. A avaliação tem como objetivo a redução de massa documental, agilidade na recuperação das informações, eficiência administrativa, melhor conservação dos documentos de guarda permanente, racionalização da produção e do fluxo de documentos (tramitação), libera espaço físico, incremento a pesquisa e maior aproveitamento dos recursos humanos e materiais na administração pública. Para a avaliação de documentos deve-se considerar fatores como a história do produtor do documento; a estrutura organizacional do órgão (passada e atual), as funções e atribuições legais, o processo de tomada de decisão e, claro, o conjunto de 
documentos a avaliar. Normas e resoluções do Conselho Nacional de Arquivos ${ }^{37}$ disciplinam todas essas etapas que devem ser seguidas pela Administração Pública.

Vários autores atestam que o Brasil a partir dos anos 2000 avançou na adoção de medidas concretas à transparência pública. A CGU na publicação sobre Acesso à Informação Pública, introduzindo a então recente lei de acesso aprovada, afirma que o Brasil já era referência em matéria de divulgação espontânea de informações governamentais: "o Portal da Transparência do Governo Federal, criado e administrado pela CGU, já foi várias vezes premiado, nacional e internacionalmente, sendo considerado um dos mais completos e detalhados sites de transparência do mundo" (BRASIL/CGU, 2011, p.3).

Figura 3 - Linha do tempo das ações de Transparência Pública

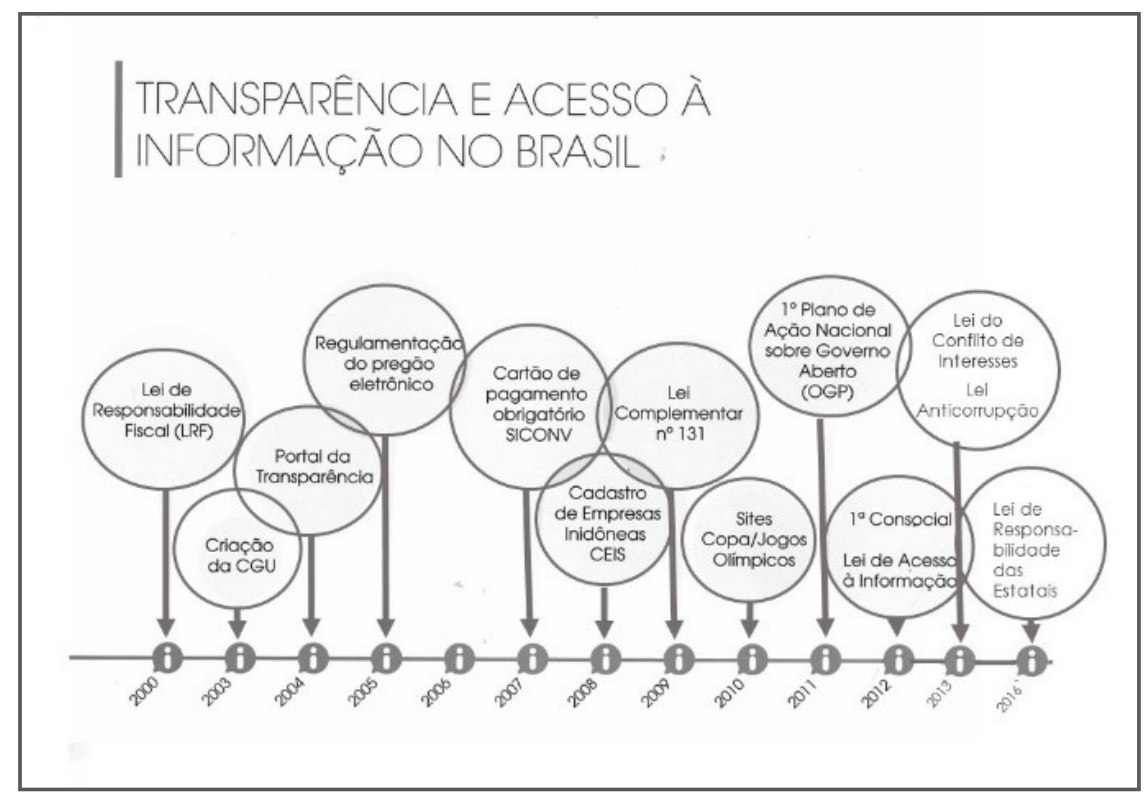

Fonte: elaborado pela autora com base figura do Balanço $1^{\circ}$ ano da LAI ${ }^{38}$

Após a promulgação da Lei de Acesso à Informação, que veremos a seguir, se seguiram outras leis que fortaleceram a ideia da transparência pública como elemento de fortalecimento do Estado Democrático e de combate à corrupção e de desvios nas finalidades do papel do Estado como listamos na seção 2.1.2 deste trabalho, e que foram incluídos na linha do tempo

\footnotetext{
${ }^{37}$ Base de dados das Resoluções do CONARQ está disponível na página na internet do conselho em legislação resoluções. < http://www.conarq.arquivonacional.gov.br/legislacao/resolucoes.html >.

${ }^{38}$ Balanço $1^{\circ}$ ano da LAI (BRASIL/CGU, 2013, p.7)
} 
acima. A Lei de Conflito de Interesses - Lei $\mathrm{n}^{\circ}$ 12.813, de 16 de maio de 2013, determina a obrigação da pessoa jurídica elaborar um Programa de Integridade, cabendo a CGU a fiscalização no âmbito da administração pública federal. Um dos itens deste programa é a transparência pública do órgão. O relatório de análise da ECT, divulgado em 2016, será um dos dados analisados neste estudo, no capítulo 5.

\subsubsection{A Lei de Acesso à Informação no Brasil}

O primeiro país a adotar um marco legal sobre acesso a informação governamental foi a Suécia em 1776. Na América Latina, a Colômbia foi a pioneira, desde sua independência em 1888, em estabelecer uma legislação que franqueou o acesso a documentos de governo. Sá e Malin (2012, p.8) destacam como característica importante, em se tratando de América Latina, que a Colômbia não passou por regime militar e nem de suspensão de eleições.

Sá e Malin (2012, p.9) destacam que até a década de 1990, quando apenas 13 países possuíam LAI, o direito à informação estava restrito a uma medida de governança administrativa e que atualmente esse conceito evoluiu a ser percebido como um direito humano fundamental. Segundo as autoras, a LAI do México é considerada um modelo de excelência.

O Brasil tornou-se o $89^{\circ}$ país a adotar uma Lei de Acesso à Informação Pública (LAI), mas foram necessários 22 anos para que o dispositivo constitucional virasse lei.

Sobre a trajetória do Projeto de Lei (PL) de Acesso à Informação no Brasil, Rodrigues (2013, p.425) destaca que o então presidente Luiz Inácio Lula da Silva (2003-2010), enviou "somente em maio de 2009, um ano antes do término do seu segundo mandato, embora desde 2003 tramitasse no Congresso Nacional um projeto de lei sobre o tema e outro, no mesmo sentido, tivesse sido formulado no legislativo em 2007 (Projetos dos deputados Reginaldo Lopes e de Celso Russomanno) ". Aspecto importante destacado pela autora é a política de comunicação institucional como espaço de comunicação interna e externa de acesso à informação pública. Com as novas tecnologias, acesso público da rede mundial de computadores e redes sociais, os espaços para disponibilização da informação pública estão cada vez mais simples e possíveis. 
Reis (2014) registra que o início do anteprojeto possui dois marcos: o começo da trajetória da proposta na CGU e o outro quando o debate ganha força com a criação do Fórum de Direito de Acesso a Informações Públicas.

O ano de 2003 data a constituição do Fórum de Acesso a Informações Públicas, que, naquele ano, realiza o primeiro seminário internacional de direito de acesso a informações. Participam desse momento organizações não governamentais, como o SOS Imprensa, a Associação Brasileira de Jornalismo Investigativo (Abraji), os movimentos Transparência Brasil e Contas Abertas, além de convidados internacionais, tais como Ernesto Villanueva - político mexicano que integrara o Comitê Gestor de Liberdade de Informação do México. Naquele momento, a Lei Mexicana de Acesso à Informação - conhecida como Lei Oaxaca -, que tanto influenciou a legislação brasileira de acesso à informação, já existia. (REIS, 2014, p.54)

Cunha Filho e Xavier (2014, p.69) relatam também que a CGU elaborou um primeiro anteprojeto de lei no ano de 2006, enviado no mesmo ano para a Casa Civil, a partir de debates travados no âmbito do Conselho da Transparência Pública e Combate a Corrupção. Em 2009, o poder executivo apresentou à Câmara dos Deputados o Projeto de Lei $n^{\circ}$ 5228/09, que tramitou sob regime de urgência. O projeto foi aprovado pelo plenário da Câmara em abril 2010, remetido ao Senado Federal, que passou a tramitar sob o número de PLC no 41/2010 (Projeto de Lei oriundo da Câmara), e foi a votação e aprovação no plenário no dia 25 de outubro de 2011. Os autores destacam a divergência quanto ao prazo máximo para restrição de acesso a informações classificadas. Os senadores Fernando Collor (PTB-AL) e José Sarney (PMDB-AP), dois ex-presidentes da República, eram contra o prazo de 50 (cinquenta) anos inicialmente proposto para acesso às informações classificadas. Collor ainda apresentou um substitutivo, como relator do projeto em que pudesse ser prorrogado por indefinidas vezes o prazo máximo. Segundo Reis (2014, p.56) a decisão de abrir para a sociedade no prazo máximo de 50 (cinquenta) anos alcançaria documentos relativos ao período em que estes senadores foram presidentes, e por isso a resistência.

Prevaleceu a redação original que permitia que informações ultrassecretas permaneçam sob acesso restrito pelo prazo de 25 anos, prorrogável pelo mesmo período. Esse acirramento também está presente em Angélico (2012, p.89) ao analisar o cenário brasileiro quanto a LAI e seus possíveis desdobramentos à accountability democrática no país.

Cotejando-se os princípios de um regime de direito à informação com as argumentações do ex-presidente Collor, conclui-se que o substitutivo apresentado viola ao menos dois princípios: obrigação de publicar e divulgação máxima. 
A forte oposição do ex-presidente Collor à aprovação da Lei de Acesso nos termos em que fora aprovado na Câmara dos Deputados (LOPES, 2003), gesto que contou com o apoio do também senador e ex-presidente José Sarney, colocou o Executivo contra as cordas: o vice-presidente Michel Temer chegou a declarar que o projeto não era prioridade. (FOLHA DE SÃO PAULO, 2011). (ANGÉLICO, 2012, p.89)

A promulgação da Lei de Acesso à Informação - Lei no 12.257 se deu no dia 18 de novembro de 2011, e no seu último artigo (art. 47), determinou que a mesma entraria em vigor 180 dias após a data de publicação. Assim, a LAI tinha data certa para começar a valer: dia 16 de maio de 2012.

No Brasil existe uma "máxima" que popularmente se usa quando uma nova lei é aprovada: "a lei vai pegar?". De acordo com Vieira (2014, p.1) especialistas ouvidos foram categóricos em dizer que sim, por ser uma lei que ia ser usada mais e mais pela sociedade engajada com a transparência em termos de internet, de redes sociais e de ativismo social. Logo no início da vigência de uma lei, principalmente pelos aspectos culturais envolvidos, se percebe pelas ações da própria administração pública para a implantação, se aquela legislação vai ser respeitada e ter a confiança da sociedade. Ao destacar o controle das informações nas mãos dos agentes políticos e públicos, Reis $(2014$, p.64) mostra a assimetria de poder entre os atores que compõem o jogo democrático, onde o cidadão comum é normalmente afastado. A autora se refere ao poder relegado aos "políticos profissionais", próprio da democracia representativa, pela qual elegemos nossos representantes (vereadores, deputados, senadores, prefeitos, governadores, presidente) e não atuamos diretamente.

Se o paradigma do silêncio e da opacidade manteve-se em vigor em grande parte da história brasileira, o paradigma da transparência corresponde, agora, a uma expectativa, a uma possibilidade. Ocorre, porém, que essa transformação carrega em si o ranço de um acúmulo histórico. A Constituição de 1988, ao tornar obrigatórios os concursos públicos, garantir o direito do cidadão às informações sob a custódia da Administração Pública, oferecer remédios constitucionais voltados à garantia de informação, como o Habeas Data, e assumir a transparência como um valor de Estado, contribui sobremaneira para o fortalecimento dessa possibilidade. (REIS, 2014, p.67)

A aprovação da LAI é um marco importante para a sociedade brasileira e para os agentes públicos, seja para a geração que se formou no ambiente de que a regra era o sigilo, seja para a nova geração que chega, dominando as novas tecnologias. Em busca de celeridade nos processos, muitos servidores, resistentes a LAI no seu início, passaram a ver na transparência das informações públicas uma aliada para o desenvolvimento de suas funções. 
Pelas características da empresa, que iremos expor neste estudo, nos interessa identificar como a LAI chega neste ambiente organizacional marcado pela cultura do sigilo e de caráter híbrido, público e empresarial, sob o ponto de vista do cidadão, dos empregados que em nome da empresa buscam atender ao cidadão e aos órgãos de controle.

No período analisado podemos perceber que a LAI continua sendo utilizada pelos cidadãos. Mais de 334 mil pedidos registrados, de 2012 a 2015, no poder executivo da administração pública federal, sendo 6.773 foram dirigidos à ECT. Uma quantidade expressiva que representou para a ECT, no $1^{\circ}$ ano da LAI, ocupar a quinta posição de órgãos com mais pedidos registrados.

Tabela 2 - Evolução dos Pedidos de Informação (2012 a 2015)

\begin{tabular}{|c|c|c|c|c|}
\hline ANO & $\begin{array}{c}\text { DEMAIS } \\
\text { ORGÃOS }\end{array}$ & ECT & TOTAL & \% ECT \\
\hline $\mathbf{2 0 1 2}$ & 54.031 & 1.181 & 55.212 & 2,14 \\
\hline $\mathbf{2 0 1 3}$ & 85.016 & 1.645 & 86.661 & 1,9 \\
\hline $\mathbf{2 0 1 4}$ & 87.954 & 2.213 & 90.167 & 2,45 \\
\hline $\mathbf{2 0 1 5}$ & 100.689 & 1.734 & 102.423 & 1,69 \\
\hline TOTAL & 327.690 & $\mathbf{6 . 7 7 3}$ & $\mathbf{3 3 4 . 4 6 3}$ & $\mathbf{2 , 0 3}$ \\
\hline
\end{tabular}

Fonte: elaborado pela autora com base nos Relatórios do e-SIC ${ }^{39}$

A LAI estabelece no art. 11 que o órgão deverá autorizar ou conceder o acesso imediato à informação disponível. Não sendo possível, deve providenciar em prazo não superior a 20 (vinte) dias, com possibilidade de prorrogar por mais dez dias. Portanto, os pedidos de prorrogação são, inicialmente, uma amostra da impossibilidade do órgão dar acesso imediato, necessitando de mais tempo para providenciar. No Gráfico 1 podemos conferir que a ECT destoou de todos os demais órgãos da administração pública federal. Enquanto para os demais órgãos não chega a $10 \%$ dos pedidos prorrogados, na ECT, em 2012, foram cerca de 49\%, conseguindo uma redução para 30\%, em 2015. Mesmo assim, permanece a ECT bem acima da média.

\footnotetext{
${ }^{39} \mathrm{Na}$ tabela a coluna TODOS representa todos os pedidos registrados no e-SIC de todos os órgãos da Administração Pública Federal, incluindo os direcionados à ECT, e na coluna ECT apenas os registrados recebidos pela ECT.
} 
Gráfico 1 - Evolução do Pedidos de Prorrogação - Demais órgãos X ECT (2012/2015)

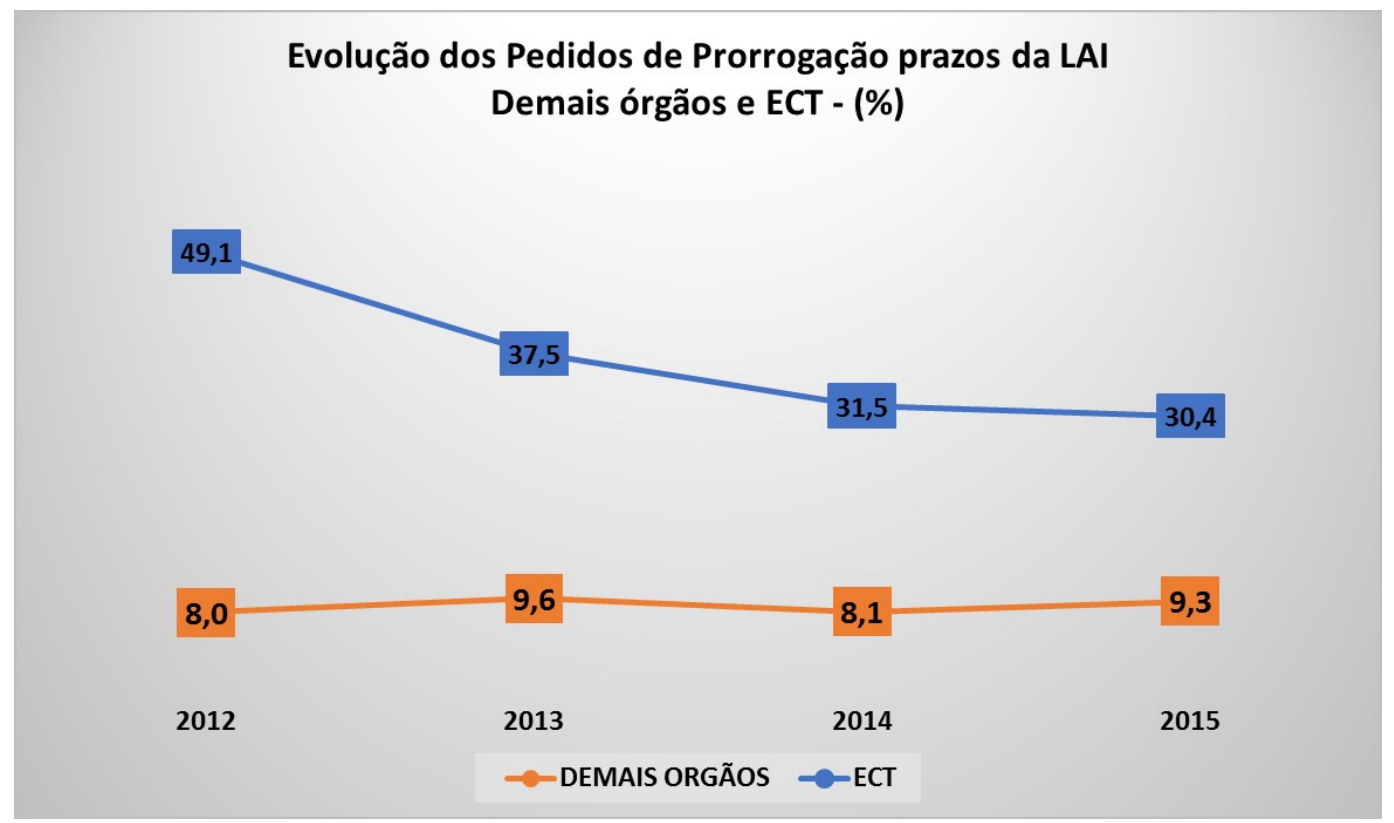

Fonte: elaborado pela autora com base dos Relatórios do e-SIC

Outro dado importante são os motivos para registro de recursos. Dos 6.773 pedidos registrados no período analisado, foram registrados 794 recursos (11,7\%) dos quais identificamos que mais de $68 \%$ dizem respeito à condição da resposta concedida. Foram 301 (38\%) por informação incompleta e $243(30,6 \%)$ em que a informação concedida não correspondia com a informação solicitada. O cidadão considerou a informação incompleta ou que a informação não correspondia com a que foi solicitada, ou seja, diferente do que se pode supor a maioria dos recursos não foi por acesso negado, mas pela condição da informação concedida. Esta situação também está presente nos demais órgãos da administração pública. 
Gráfico 2 - Principais motivos: Recurso 1ª Instância / ECT (2012/2015)

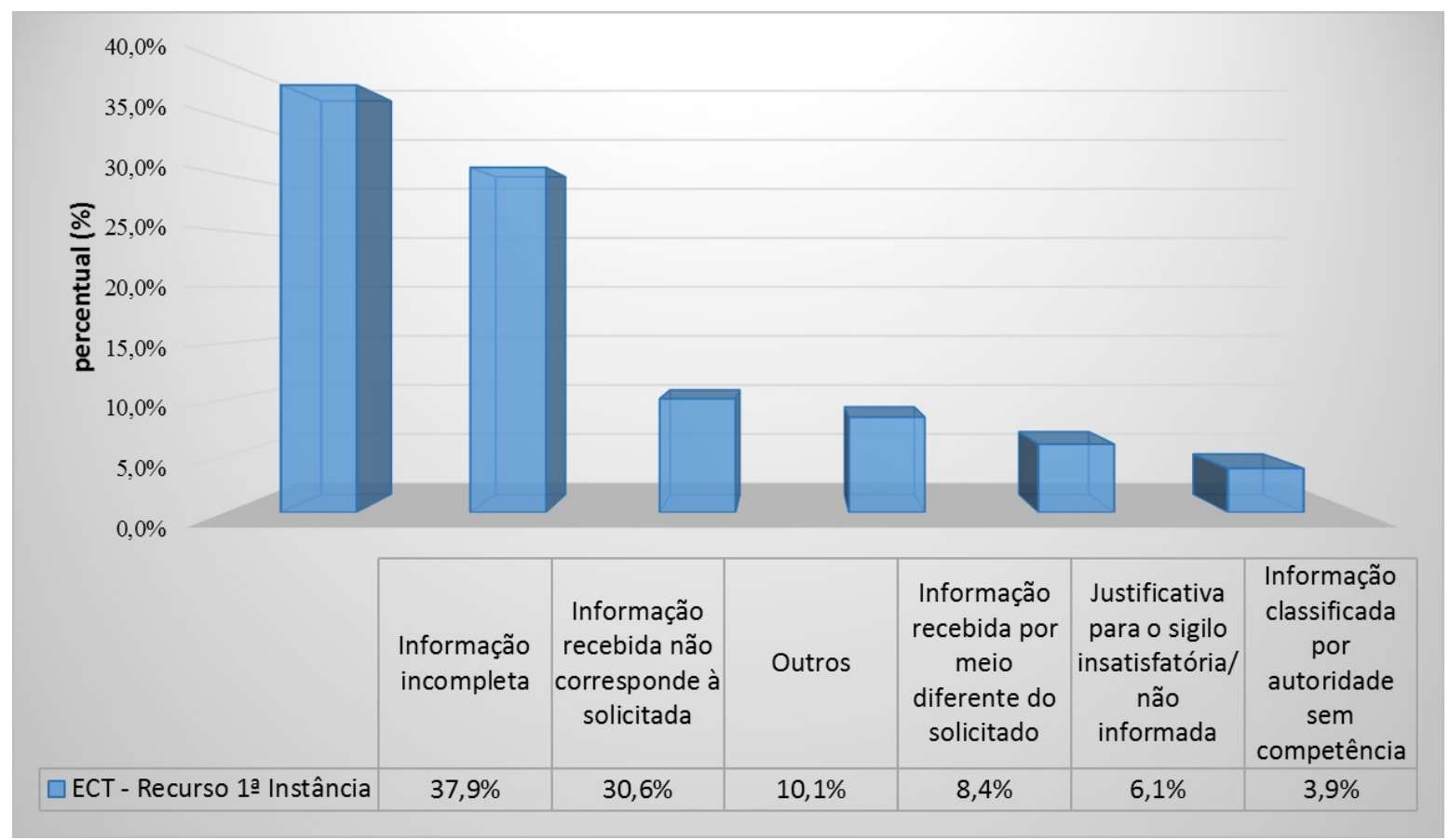

Fonte: elaborado pela autora com base dos Relatórios do e-SIC

Neste sentido, reveste-se de importância o estudo da organização da informação na ECT, como veremos no Capítulo 3.

\subsection{Os Correios: Empresa Pública S.A.}

Os Correios no Brasil confundem sua história com a própria história da nação brasileira que se inicia exatamente com a carta enviada por Pero Vaz de Caminha ao rei de Portugal, em $1^{\circ}$ de maio de 1500, noticiando assim o descobrimento do Brasil. Na página na internet da ECT é possível ter acesso a mais detalhes sobre a história deste serviço secular. Apresentamos um breve histórico para melhor contextualizar o período que vamos abordar no nosso trabalho. 
Quadro 2 - Histórico do Serviço Postal no Brasil $\left(1500\right.$ - 2016) ${ }^{40}$

\section{Início do Serviço Postal}

1500 A Carta de Pero Vaz de Caminha, que anunciou ao rei de Portugal o descobrimento da nova terra - a primeira ligação postal entre o Brasil e a metrópole.

1520 Nomeado o primeiro Correio-Mor do Reino.

1663 Designação dos primeiros assistentes do Correio-Mor para o Brasil, efetivados em 25 de janeiro de 1663 - iniciou-se oficialmente o serviço postal no país, e nesta data se comemora o Dia do Carteiro no Brasil.

1710 Nomeado o Assistente do Correio-Mor da Capitania do Rio de Janeiro. Pela primeira vez, havia previsão oficial de que se pudessem nomear ajudantes para o interior do Brasil, em regiões como as Minas Gerais e São Paulo.

1715 Foi proibido o serviço para o interior do país pelo governador do Rio de Janeiro, possivelmente interessado em controlar as informações sobre as novas riquezas descobertas.

1730 O rei D. João $\mathrm{V}$ proíbe definitivamente que o Correio-Mor criasse ligações para o interior do Brasil. A proibição se alinha a outros atos de controle realizados pela coroa portuguesa ao longo do século XVIII, visando à coibir a circulação de novas ideias e a dificultar que vazassem notícias sobre as minas de ouro.

1797 O ofício de Correio-Mor do Reino e Domínios foi extinto e reincorporado à Coroa. Ministro de Estado da Marinha e Ultramar reivindica para a Coroa a Administração dos Serviços Postais e assume como primeiro Diretor dos Correios Luís Pinto de Souza.

\section{A Estatização dos Serviços}

1798 Instituído o processo de organização postal dos correios terrestres e estabelecida a ligação postal marítima regular entre o Brasil e Portugal (Rio de Janeiro e Lisboa, inicialmente).

1799 Data de $1^{\circ}$ de abril o Regulamento Provisional para o Novo Estabelecimento do Correio, instituindo administrações terrestres e ultramarinas.

1808 A Família Real Portuguesa chegou ao Brasil em 7 de março, e o País passou da condição de colônia à de sede do governo português, localizada no Rio de Janeiro. Instituído o em definitivo o primeiro Regulamento Postal no Brasil

1809

Fixado o Serviço Postal entre Rio de Janeiro e São Paulo 
Período Imperial

1828 Ministro e Secretário dos Negócios do Império apresenta a proposta de reorganização dos serviços postais, formalizada pelo Decreto de 30 de setembro.

1829 Unificação de todas as linhas postais então existentes numa administração geral, a "Administração dos Correios", bem como a criação de administrações provinciais.

1831 Supressão do cargo de diretor-geral dos Correios, competindo a direção e a inspeção dos mesmos, na Corte, ao ministro do império; e nas províncias, aos presidentes.

1835 Adoção da entrega domiciliar de correspondência; uso de uniforme com bolsa de cartas a distribuir e outra para a introdução de cartas pelos transeuntes.

1843 Em 1840, a Inglaterra cria o primeiro selo postal adesivo - o pagamento da correspondência passa a ser do remetente e não pelo destinatário, o selo é o comprovante desse pagamento. Em 1843, o Brasil emite os primeiros selos postais, os Olhos-de-Boi, nos valores de 30, 60 e 90 réis. O Brasil foi o segundo país do mundo a adotar essa solução em todo o seu território.

1845 Instalação das primeiras Caixas de Coleta do Império, no Rio de Janeiro.

1852 Instalação do telégrafo elétrico no Brasil com o objetivo de contribuir com o combate ao tráfego negreiro.

1861 Criação da Secretaria do Estado dos Negócios da Agricultura, Comércio e Obras Públicas com a qual se vinculavam os correios terrestres e marítimos.

1865 Iniciado o Serviço de Vale Postal para o território brasileiro.

1877 É inaugurada a Agência $1^{\circ}$ de Março no Rio de Janeiro, primeira edificação especialmente construída para os serviços de Correios no Brasil, de acordo com as mais avançadas técnicas arquitetônicas da época.

1880 Edição do Guia Postal do Império do Brasil.

1888 Promulgação do Decreto 9.912, de 26 de março, instituindo o Regulamento dos Correios do Império.

\section{Correios na República Velha}

1889 Criado o primeiro Museu Postal Brasileiro.

1890 A Repartição Postal ficou subordinada ao Ministério da Instrução Pública, Correios e Telégrafos.

1900 O Brasil inicia o serviço de Encomendas Internacionais (Colis Postaux).

1901 Entrada em serviço dos vales internacionais.

1907 Edição do primeiro Guia Postal do período republicano.

1909 A Repartição Postal passa a ser subordinada ao Ministério da Indústria, Viação e Obras Públicas.

1917 Instituída a censura postal, durante a 1 a Guerra Mundial

1919 Extinção da censura e circulação da Revista Postal Brasileira 
1921 Realização do primeiro transporte de malas postais via aérea, em $1^{\circ}$ de fevereiro.

1924 Início do uso da máquina de franquear correspondências, fabricada pela Universal Postal Frankess, de Londres.

1925 Transportada a primeira Mala Aérea internacional pela Compagnie Générale D'Enterprises Aéronautiques (CGA).

1927 Início do transporte de correspondência via aérea regular, entre a América do Sul e a Europa.

1929 Uso do Graff Zeppelin - dirigível que sobrevoava regularmente os céus do Brasil transportando, entregando e recebendo correspondências (ligação Europa e a América do Sul, depois incluiu os Estados Unidos).

\section{CORREIOS na "República Nova" - Período DCT}

1931 Criado o Departamento de Correios e Telégrafos (DCT), subordinado ao Ministério da Viação e Obras Públicas. É criado o Correio Aéreo Militar, que deu origem ao Correio Aéreo Nacional.

1934 Foi instituída a Escola de Aperfeiçoamento dos Correios e Telégrafos. Iniciou-se o uso de máquina de triagem denominada "Transorma".

1941 Criação do Correio Aéreo Nacional (CAN), pela fusão do Correio Aéreo Militar (CAM) com o Correio Aéreo Naval (CAN).

1951 Regulamento dos Serviços Postais e Telegráfico por decreto ${ }^{41}$

\section{CORREIOS na Ditadura Militar - Período ECT}

1967 O Decreto-Lei n 200 institui o Ministério das Comunicações.

1968 O DCT passa a ser subordinado ao Ministério das Comunicações.

1969 O Decreto-Lei $n^{0}$ 509, em 20 de março, transformação do DCT na Empresa Brasileira de Correios e Telégrafos.

1971 Lançamento do primeiro Guia Postal Brasileiro, com o Código de Endereçamento Postal (CEP) representado por cinco algarismos

1978 Lei Postal 6.538 Criação da Escola Superior de Administração Postal (ESAP), em e Inauguração, no mês de junho, do Edifício-Sede da ECT, em Brasília

\section{CORREIOS na Redemocratização}

\footnotetext{
${ }^{41}$ Não há registros a serem destacados nos serviços postais de 1951 a 1967. Bovo (1997, p.22) informa que foi um período de completo abandono do Departamento (DCT): “Os serviços do DCT eram motivo de pilhéria por parte da população. As cartas demoravam para chegar ao destino, quando chegavam”. Em todas as fontes consultadas relacionadas aos Correios, não encontramos informações deste período.
} 
1986 Participação da ECT no Programa de Prioridades Sociais do Governo Federal e na distribuição de livros didáticos e tíquetes de leite.

1999

Inauguração Centro Operacional de Recife (PE), iniciou-se fase da automação dos processos operacionais da ECT e processo de automação da rede de Agência

2000 Primeira agência do Banco Postal no Espirito Santo

2003 O apoio dos Correios ao Programa Fome Zero possibilitou a arrecadação e entrega de 615 toneladas de alimentos à população.

2007 Inauguração de Central Braille, para o atendimento de pessoas com problemas visuais

2009 Julgamento do Supremo Tribunal Federal (STF) garante a exclusividade da ECT na prestação dos serviços postais

2011 Publicação da Lei 12.490, que moderniza e fortalece os Correios, e do novo Estatuto da empresa. Realização do maior concurso público da história do País

2012

Implantação do Serviço de Informação ao Cidadão (SIC)

2013 Início do uso de smartphones pelos carteiros para aprimoramento dos serviços de distribuição domiciliária.

2015

Assinatura do Termo de Cooperação Técnica com o Ministério do Planejamento para adesão ao Sistema Eletrônico de Informações - SEI

Fonte: elaborado pela autora ${ }^{42}$

\subsubsection{Administração Indireta}

A administração burocrática clássica, segundo Bresser-Pereira (1996, p.4) foi implantada no Brasil em 1936, com a reforma administrativa promovida por Mauricio Nabuco e Luís Simões Lopes, “é a burocracia que Max Weber descreveu, baseada no princípio do mérito profissional". O autor recupera ainda que a administração burocrática foi adotado para substituir a administração patrimonialista onde as monarquias absolutas confundiam o patrimônio público e privado, onde o nepotismo, o empreguismo e a corrupção eram a norma. Assim, em 1938, com a criação da primeira autarquia, a ideia de que os serviços públicos na "administração indireta" deveriam ser descentralizados e não obedecer a todos os requisitos

\footnotetext{
${ }^{42}$ Foram consultadas a página da internet da ECT - "História Postal" (http://correios.com.br/sobre-correios/aempresa/história) e as referências bibliográficas em Miranda (1999) e Teixeira (2013).
} 
burocráticos da "administração direta" ou central, passam a estar presentes (BRESSERPEREIRA, 1996, p.6)

Abrucio (2007) também destaca o quanto o regime militar foi negativo para a gestão pública.

O regime autoritário foi pródigo em potencializar problemas históricos da administração pública brasileira, como o descontrole financeiro, a falta de responsabilização dos governantes e burocratas perante a sociedade, a politização indevida da burocracia nos estados e municípios, além da fragmentação excessiva das empresas públicas, com a perda de foco de atuação governamental (ABRUCIO, 2007, p.68).

s militares justificavam as mudanças na Administração Pública pela ineficiência da máquina pública, conforme destacam Miranda (1999) e Teixeira (2013) no caso dos Correios.

O ano de 1969 é marcado por profunda modificação nos correios brasileiros. Até então, o serviço postal era explorado pelo DCT, órgão vinculado ao Ministério de Viação e Obras Públicas e que apresentava carências significativas, a saber: instalações precárias, ausência de parâmetros de qualidade, serviços prestados por tradição, servidores despreparados e insatisfeitos, além de restrição de atuação em apenas alguns pouco serviços convencionais, com tarifas aviltadas e a existência de inúmeras organizações que gozavam de franquia tarifária (TEIXEIRA, 2013, p.41 apud BOLETIM INTERNO, "Encontro nacional....", 1992) [...]

[...] O quadro traduzia-se em mau atendimento à população brasileira que, à época, não confiava nos serviços postais públicos e ansiava por mudanças. (MIRANDA, 1999, p.45)

[....] Os métodos de trabalho no final da década de 1960, no entanto, eram tidos como ineficientes e obsoletos e o sucateamento das instalações somavase ao quadro (BARROS NETO, 2004) [...]

[...] O diretor da ECT na década de 1970, coronel Haroldo Corrêa de Mattos, tinha como missão soerguer a ECT a partir de transformações na estrutura e nos serviços da empresa. Para isso, contava não só com os instrumentos e aparatos técnico-administrativos como também com a lógica de poder militar que o acompanhou em suas atividades gerenciais. (TEIXEIRA, 2013, p.41)

O Decreto-Lei é um decreto com força de lei com origem no poder executivo, quando este acumula de forma não convencional as funções do legislativo. Os governos militares fizeram uso do Decreto-Lei, para impor a estrutura de Estado que assim desejavam, não havendo, portanto, representação da sociedade. É exatamente este o caso do DL200 que "dispõe sobre a organização da Administração Federal, estabelece diretrizes para a Reforma Administrativa e dá outras providências". Logo no seu preâmbulo o decreto-lei se refere ao Ato Institucional $\mathrm{n}^{\mathrm{o}} 4$ (AI4) que confere amplos poderes ao Presidente da República. "O 
PRESIDENTE DA REPÚBLICA, usando das atribuições que lhe confere o art. $9^{\circ}, \S 2^{\circ}$, do Ato Institucional $n^{\circ} 4$, de 7 de dezembro de 1966, decreta: ".

Art. $9^{\circ}$ - O Presidente da República, na forma do art. 30 do Ato institucional $\mathrm{n}^{\mathrm{o}} 2$, de 27 de outubro de 1965, poderá baixar Atos Complementares, bem como decretos-leis sobre matéria de segurança nacional até 15 de março de 1967.

$\S 1^{\circ}$ - Durante o período de convocação extraordinária, o Presidente da República também poderá baixar decretos-leis sobre matéria financeira.

$\S 2^{\circ}$ - Finda a convocação extraordinária e até a reunião ordinária do Congresso Nacional, o Presidente da República poderá expedir decretos com força de lei sobre matéria administrativa e financeira. (BRASIL/AI4, 1966)

O caráter autoritário do DL200 que institui a Administração Pública gerencial no Brasil em 1967, está determinado em sua origem. Apesar do processo de redemocratização do Estado brasileiro, e de alguns autores considerarem que houve um retorno ao modelo de administração burocrática de 1988 a 1998, a verdade é que o DL200 continua em vigor até os dias de hoje. As alterações que sofreu foram pontuais, sem alterar seus princípios e concepção.

O DL200, logo no artigo $4^{\circ}$, apresenta a administração federal dividida em duas: a administração direta e indireta. $\mathrm{Na}$ direta, inclui a estrutura administrativa da Presidência da República e dos Ministérios e na indireta, cria entidades com personalidade jurídica própria, onde destacamos as Empresas Públicas. No artigo $6^{\circ}$ apresenta os princípios fundamentais: planejamento, coordenação, descentralização e delegação de competências, quanto à forma de controle a ser exercida no âmbito da Administração Pública.

Art. $4^{\circ}$ A Administração Federal compreende:

I - A Administração Direta, que se constitui dos serviços integrados na estrutura administrativa da Presidência da República e dos Ministérios.

II - A Administração Indireta, que compreende as seguintes categorias de entidades, dotadas de personalidade jurídica própria:

a) Autarquias;

b) Emprêsas Públicas;

c) Sociedades de Economia Mista.

d) fundações públicas. (Incluído pela Lei nº 7.596, de 1987) $[\ldots]$

Art. $6^{\circ}$ As atividades da Administração Federal obedecerão aos seguintes princípios fundamentais:

I - Planejamento.

II - Coordenação.

III - Descentralização.

IV - Delegação de Competência.

$\mathrm{V}$ - Contrôle.

(BRASIL, DL200/1967, grifo da autora) 
Com este modelo a administração pública desobriga-se da realização material de tarefas executivas, recorrendo, sempre que possível, à execução indireta, e no parágrafo $7^{\circ}$ do artigo 10 , destaca a adoção de contrato com a iniciativa privada para desempenhar os encargos de tarefas executivas, abrindo caminho para a terceirização das atividades.

Art. 10. A execução das atividades da Administração Federal deverá ser
amplamente descentralizada [...]
[...] $\S 7^{\circ}$ Para melhor desincumbir-se das tarefas de planejamento,
coordenação, supervisão e contrôle e com o objetivo de impedir o
crescimento desmesurado da máquina administrativa, a Administração
procurará desobrigar-se da realização material de tarefas executivas,
recorrendo, sempre que possível, à execução indireta, mediante contrato,
desde que exista, na área, iniciativa privada suficientemente desenvolvida e
capacitada a desempenhar os encargos de execução. (BRASIL, DL200, 1967, grifo da autora)

No artigo $5^{\circ}$ é definido cada uma das entidades da administração indireta. As empresas públicas são consideradas entidades com personalidade de direto privado, com patrimônio próprio e capital exclusivo da União para exploração e atividade econômica que o governo seja levado a exercer por "força de contingência ou de conveniência administrativa". A seguir no parágrafo único do artigo 27, estabelece que o Poder Executivo deve assegurar às empresas públicas condições de funcionamento "idênticas" às do setor privado.

II - Emprêsa Pública - a entidade dotada de personalidade jurídica de direito privado, com patrimônio próprio e capital exclusivo da União, criado por lei para a exploração de atividade econômica que o Govêrno seja levado a exercer por fôrça de contingência ou de conveniência administrativa podendo revestir-se de qualquer das formas admitidas em direito. (Art. $5^{\circ}$ - Redação dada pelo Decreto-Lei n ${ }^{\circ}$ 900, de 1969)

[...]

Art. 27. Assegurada a supervisão ministerial, o Poder Executivo outorgará aos órgãos da Administração Federal a autoridade executiva necessária ao eficiente desempenho de sua responsabilidade legal ou regulamentar.

Parágrafo único. Assegurar-se-á às emprêsas públicas e às sociedades de economia mista condições de funcionamento idênticas às do setor privado cabendo a essas entidades, sob a supervisão ministerial, ajustar-se ao plano geral do Govêrno. (BRASIL, DL200,1967, grifo da autora)

Barroso (2000) ao analisar o regime jurídico aplicável aos serviços postais a partir da entrada em vigor da Constituição Federal de 1988, particularmente no que se refere a atuação de empresas privadas no serviço postal, faz um estudo quanto a atuação econômica do Estado, dos princípios que o regem e do conjunto de dispositivos constitucionais que disciplinam os serviços públicos, que iremos abordar no decorrer de nossa pesquisa. Destacamos a seguir a 
diferenciação que o autor apresenta, e que estará presente em vários pareceres da CGU, entre a prestação de serviços públicos e a exploração da atividade econômica.

16. Os serviços públicos podem ser prestados diretamente, pelos órgãos despersonalizados integrantes da Administração, ou indiretamente, por entidades com personalidade jurídica própria. Na prestação indireta, abrem-se duas possibilidades: pode o Estado constituir pessoas jurídicas públicas (autarquias e fundações públicas) ou privadas (sociedades de economia mista e empresas públicas) e, mediante lei (CF, art. 37, XIX), outorgar a tais entes a prestação do serviço público, seja de educação, água, eletricidade ou qualquer outro. Ou pode, por outro lado, delegar à iniciativa privada, mediante contrato ou outro ato negocial, a prestação do serviço. Serve-se aí o Estado de figuras jurídicas como a concessão e a permissão. O caput do art. 175 provê sobre a matéria e será objeto de exame pouco mais à frente.

17. A exploração da atividade econômica, à sua vez, não se confunde com a prestação de serviços públicos, quer por seu caráter de subsidiariedade, quer pela existência de regras próprias e diferenciadas. De fato, sendo o princípio maior o da livre iniciativa, somente em hipóteses restritas e constitucionalmente previstas poderá o Estado atuar diretamente, como empresário, no domínio econômico. Tais exceções se resumem aos casos de:

a) imperativo da segurança nacional (CF, art. 173, caput);

b) relevante interesse coletivo (CF, art. 173, caput);

c) monopólio outorgado à União (e.g., CF, art. 177).

(BARROSO, 2000, p. 186, grifo da autora)

Outro destaque a ser feito no DL200 são os artigos 35 e 39. Até 1967 os serviços postais estavam sob responsabilidade do Departamento de Correios e Telégrafos (DCT), que estavam antes vinculados ao Ministério de Viação e Obras Públicas e pelo DL200 passam a estar vinculados ao Ministério das Comunicações, como disposto no art. 30.

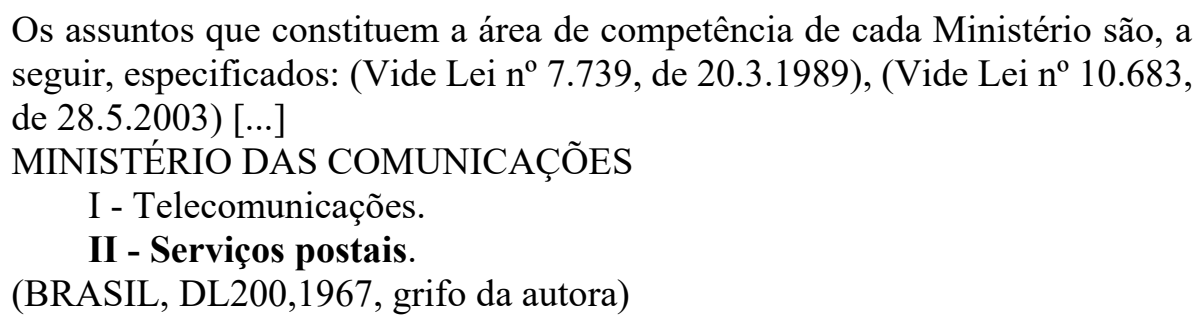

Giddens (2001, p.197) destaca que a separação da comunicação em relação ao transporte foi estabelecida logo após a invenção do telégrafo e foi tão importante quanto qualquer outra invenção anterior na história humana. $\mathrm{O}$ autor ressalta que no início as comunicações postais eram tão lentas quanto esporádicas e dependiam dos meios de transportes: animais, carroças, diligências, barcos, navios, aviões etc. Ao analisar o poder do Estado, Giddens afirma que as redes postais foram um suplemento fundamental ao telégrafo e ao seu sucessor, o telefone e enfatiza essa separação. No Brasil ela se concretiza na segunda metade do século XX, em que 
os serviços postais saem da área de transportes e se vinculam a área de comunicação, que é criada pelo DL200.

Minha intenção é enfatizar a importância para a consolidação do Estado-nação no final do século XIX e no começo do século XX da separação de informação dos transportes. O salto inicial adiante do poder administrativo gerado pelo Estado-nação foi realizado antes do desenvolvimento da comunicação eletrônica. Mas as sociedades modernas foram "sociedades eletrônicas" durante muito mais tempo do que normalmente imaginamos, e "sociedades de informação" desde o seu início. Há um sentido fundamental, como já afirmei, no qual todos os Estados foram "sociedades de informação", já que a geração do poder de Estado supõe um sistema de reprodução reflexivamente monitorado, envolvendo a reunião regularizada, armazenamento, e controle da informação voltados para fins administrativos. Porém, no Estado-nação, com seu peculiar alto grau de unidade administrativa, isso ocorre em um nível muito mais elevado. (GIDDENS, 2001, p. 199)

Neste sentido a criação do Ministério das Comunicações e a ele subordinado os serviços postais, se conformavam na geração do poder do Estado e do controle da informação.

\subsubsection{ECT - Empresa Pública S.A.}

Em 20 de março de 1969, um pouco mais de dois anos após a publicação do DL200 e mais um Ato Institucional, o AI5 ${ }^{43}$, os militares publicaram o Decreto-Lei 509 - DL509, que dispõe sobre a transformação do Departamento dos Correios e Telégrafos em empresa pública. Logo no artigo $1^{\circ}$ estabelece a transformação do DCT em Empresa Brasileira de Correios e Telégrafos (ECT) nos termos do item II do art. $5^{\circ}$ do DL200, que define empresa pública.

Outro destaque importante, e objeto de grandes debates jurídicos, é o artigo que estabelece o monopólio postal “Art. $2^{\circ}$ - À ECT compete: I - executar e controlar, em regime de monopólio, os serviços postais em todo o território nacional; [...]”, garantindo assim, sua primazia no mercado de serviço postal.

\footnotetext{
${ }^{43} \mathrm{O}$ Ato Institucional $\mathrm{n}^{\circ} 5$ deu amplos poderes ao Presidente da República e suspendeu direitos políticos e constitucionais, permitiu intervir em estados e municípios. Em outubro de 1969, os militares fecharam o Congresso Nacional, impondo a linha mais dura do regime.
} 
Teixeira (2013) destaca que o DL509 possibilitou a política de adequação dos Correios à lógica empresarial. Segundo o autor, sua nova estrutura empresarial garantiria a autonomia necessária para efetivar uma gestão aos moldes de uma empresa privada.

Assim, o Decreto-Lei no . 509, de 20 de março de 1969 - decreto de criação da ECT-, enfatiza o caráter empresarial da nova organização, alterando, portanto, o sentido de sua vinculação ao Estado e suas obrigações administrativas.

Com isso, os Correios passaram a transitar entre duas lógicas administrativas: uma empresarial e outra pública. Garantiu-se à empresa a manutenção de seu patrimônio como pertencente integralmente à União. Além disso, garantiu-se autonomia à ECT para escolher - como na lógica empresarial as estratégias de gestão que deviam guiá-la para, como em uma empresa privada, buscar a eficiência e o lucro em suas operações.

A criação da ECT não alterou significativamente a estrutura que já existia no DCT. Assim, a empresa continuou a funcionar com base nas diretorias regionais subordinadas à administração central, sediada em Brasília. (TEIXEIRA, 2013, p. 33/34, grifo da autora)

As justificativas para a mudança organizacional nos serviços postais vieram acompanhadas de um quadro de mau atendimento à população e ineficiência dos serviços prestados. Não foi diferente em 1967 quando da criação da ECT. Na página na internet da ECT - História Postal, justifica-se o DL509/1969 como uma modernização necessária para atender as necessidades dos usuários.

Com o desenvolvimento dos setores produtivos do Brasil tornava-se necessária a reorganização do serviço postal a partir de um modelo mais moderno que o do DCT, que já não apresentava infraestrutura compatível com as necessidades dos usuários. Nesse sentido foi criada, em 20 de março de 1969, pela Lei $\mathrm{n}^{\mathrm{o}}$. 509, a Empresa Brasileira de Correios e Telégrafos (ECT), uma empresa pública vinculada ao Ministério das Comunicações. O surgimento da ECT correspondia a uma nova postura por parte dos poderes públicos, com relação à importância das comunicações e, particularmente, dos serviços postais e telegráficos, para o desenvolvimento do País. Nesse período, a ECT consolidaria seu papel como importante agente da ação social do Governo, atuando no pagamento de pensões e aposentadorias; na distribuição de livros escolares; no transporte de doações em casos de calamidade; em campanhas de aleitamento materno; no treinamento de jovens carentes e em inúmeras outras situações. (BRASIL, História Postal)

Miranda (1999) destaca que, pelo mau atendimento, a população não confiava nos serviços postais públicos e desejava mudanças, que vieram com o DL509.

O quadro traduzia-se em mau atendimento à população brasileira que, à época, não confiava nos serviços postais públicos e ansiava por mudanças. Essas ocorreram a partir de 20 de março de 1969, com a criação da ECT. Seu advento como empresa pública de direito privado, vinculada a Ministério das 
Comunicações, marcou a mudança de mentalidade do Poder Público quanto a organização do Setor Postal Brasileiro. As modificações significativas, referem-se à independência financeira da União (ainda que parcial), à reestruturação organizacional e administrativa e ao incremento de qualidade na prestação dos serviços oferecidos aos usuários. (MIRANDA, 1999, p. 45)

Em 1969, um serviço instituído no país há mais de 350 anos, tem sua organização alterada através de um decreto-lei, por um governo sem legitimidade democrática, cujas consequências serão tornadas públicas, mais de 30 anos depois, que trataremos na seção sobre a CPMI dos "Correios".

Portanto, a década de 1970 pode ser caracterizada pela diversificação para buscar eficiência e lucro. Segundo Teixeira (2013, p. 36), inúmeros incidentes ocorreram de disputa entre empresas privadas e a violação do monopólio postal, e chegou a ser caso policial.

Nos anos 1980, não foi diferente, mas desta vez foram as multinacionais que buscaram atuar no mercado postal brasileiro, o que impôs aos Correios uma atuação também na esfera política para a defesa do monopólio, segundo o autor.

Formulação de um amplo programa de investimentos para o período 1995/1999, com enlace até 2003, a ser executado pelas empresas do setor de comunicações - públicas e privadas —, condizente com o elenco de diretrizes e metas traçadas para os serviços de telecomunicações e postais. [...]. Implementação de novo modelo institucional para o setor (postal e de telecomunicações), incentivando a competição na exploração dos serviços, com intensa participação de capitais privados e implantação do cenário de transição para privatização integral da operação do setor [...]. Modernização dos serviços postais. (TEIXEIRA, 2013, p. 60 apud BRASIL, S/D, p. 02).

No período de 1994 a 2011 a ECT passou por várias transformações. Mudanças iniciadas no governo de Fernando Henrique Cardoso (1995 - 2002), e que segundo Teixeira (2013, p. 59) influenciaram as decisões estratégicas para o setor postal durante os governos dos presidentes Luís Inácio Lula da Silva e Dilma Rousseff.

No governo FHC foram mudanças planejadas nas áreas de telecomunicações e serviço postal que previa a modernização da infraestrutura e do sistema gerencial, para posteriormente, proceder sua privatização, como acabou ocorrendo nas telecomunicações, segundo o autor (Ibid, p.60). Em 1995, o governo apresentou o Programa de Recuperação e Ampliação do Sistema de Telecomunicações e do Sistema Postal (PASTE) e, em 1998, finalizou o Programa de Reforma Estrutural do Setor Postal Brasileiro (RESP), cujo principal produto foi convertido 
no projeto de Lei Geral do Sistema Nacional de Correios - Projeto de Lei $1.491^{44}$ de 12 de agosto de 1999. O PL propunha a liberalização do mercado postal, e assim o fim do monopólio em 10 anos, transformando a ECT em "Correios S.A.", passando a ser empresa de economia mista.

O projeto de lei que propunha o Sistema Nacional de Correios, que à época se tornou conhecido como nova Lei Postal, foi desenvolvido e organizado para transformar radicalmente o setor. Sua concepção e desenvolvimento tiveram como inspiração as orientações da União Postal Universal, Banco Mundial e reformas realizadas no âmbito da OCDE, sobretudo de países situados na União Europeia. A inspiração ideológica neoliberal, portanto, orientou a concepção do projeto. (TEIXEIRA, 2013, p.62/63)

Pela oposição dos empresários, que não concordavam com a manutenção do monopólio, e as mobilizações dos trabalhadores dos Correios, o PL não foi aprovado.

O governo Lula (2003 - 2010) apresentou uma outra visão quanto a ECT e cumprindo compromisso assumido com os trabalhadores, enviou em 24 de outubro de 2003, Mensagem ${ }^{\circ}$ 558 da Presidência da República à Câmara dos Deputados solicitando a retirada de pauta do $\mathrm{PL}^{45}$. Segundo Teixeira (2013, p.71), enquanto o governo FHC desejava a abertura do mercado postal, o governo Lula justifica as mudanças na estatal como forma de fortalecê-la para atuar em um mercado mais acirrado.

Teixeira (2013) descreve que em 2008, o então Ministro das Comunicações Hélio Costa, havia solicitado ao Presidente Lula a formação de um Grupo de Trabalho para analisar o setor postal e propor medidas de modernização. Foi criado um Grupo de Trabalho Interministerial (GTI) envolvendo os Ministérios da Comunicação, Planejamento e Casa Civil da Presidência da República. O autor, ao descrever os pontos apresentados no Relatório do GTI, destaca que a recomendação de reestruturação da ECT como uma empresa pública sob forma de sociedade anônima com capital exclusivamente da União, encontrou forte resistência no movimento sindical. Apesar de não explicitar no texto da lei a expressão "sociedade anônima", incorporou os princípios e instrumentos da Lei das Sociedades Anônimas. Não houve a abertura de capital

\footnotetext{
44 Tramitação disponível na página da Câmara dos Deputados, em $<$ http://www.camara.gov.br/proposicoesWeb/fichadetramitacao?idProposicao=139546>

${ }^{45}$ O PL 1491/1999 retirado de pauta em outubro de 2003, voltou a tramitar na Câmara e está desde o dia 18/06/2015 na Comissão de Trabalho, de Administração e Serviço Público (CTASP); Designado Relator, Dep. Benjamin Maranhão (SD-PB).
} 
da empresa, que continua sendo integralmente da União, mas a adequação organizacional e administrativa aos princípios de uma visão de corporatização.

Para a adequação da ECT às diretrizes das sociedades anônimas, a estrutura
organizacional da estatal foi alterada, com o acréscimo de órgãos de natureza
administrativa. Dessa maneira, se antes a administração da ECT estava a cargo
de um presidente responsável pela Diretoria, com a reestruturação
organizacional passou a contar com um Conselho de Administração, uma
Diretoria Executiva (formada pelo presidente e oito vice-presidentes) e um
Conselho Fiscal, atendendo aos anseios por melhorias na governança
corporativa.
Como órgão máximo de decisão, criou-se na ECT a Assembleia Geral para
deliberação das questões mais relevantes, com publicação de ata com as
decisões tomadas. O Conselho de Administração, responsável por orientar e
definir as estratégias de negócios, objetivos corporativos e monitor os
resultados, inclui no processo decisório sete membros. (TEIXEIRA, 2013,
p.75)

Em 2009, o debate sobre o monopólio postal chega ao Supremo Tribunal Federal (STF), mais uma tentativa de retirada da presença efetiva da empresa, que mantém o monopólio definindo o escopo de sua atuação, que veremos mais adiante na seção sobre o caráter hibrido da estatal.

Em 2011, no governo Dilma Rousseff (2011 - 2016) é editada a Medida Provisória ${ }^{\circ}$ 532, convertida pelo Congresso Nacional na Lei $\mathrm{n}^{\mathrm{o}} 12.490$, que traz as primeiras alterações ao DL509. As alterações presentes incluem: a possibilidade de atuação da empresa no exterior, possibilitando constituir subsidiárias e adquirir o controle ou participação acionária em sociedades empresariais já estabelecidas; novos serviços postais como logística integrada, serviços financeiros e eletrônicos. Retira-se a estrutura de Diretorias Regionais, presente antes nos parágrafos do artigo $4^{\circ}$, cabendo ao Estatuto, a ser expedido por decreto, estabelecer a organização, atribuições e funcionamento dos órgãos que compõe sua estrutura básica. E entre outros itens destacamos um dos mais importantes: passa a poder aplicar, subsidiariamente, ao DL509, a Lei 6.404/76, que dispõe sobre a sociedade por ações (sociedade anônima ou companhia), agora sim, S.A.

Apesar do recorte temporal de nosso projeto ser até 2015, não podemos deixar de incluir a que está sendo chamada de "Lei de Responsabilidade das Estatais" ou "Lei das Estatais". A Lei ${ }^{\circ} 13.303$, de 30 de junho de 2016, dispõe sobre o estatuto jurídico da empresa pública, da sociedade de economia mista e de suas subsidiárias, no âmbito da União, dos Estados, do Distrito Federal e dos Munícipios. Esta lei já vinha tramitando pelo Senado Federal desde 2015, e veio disciplinar a exploração direta de atividade econômica pelo Estado, através de suas 
empresas estatais, como previsto no art. 173 da CF. É importante destacar que ela apresenta vários mecanismos de transparência e governança, como divulgação de informações, práticas de gestão de risco, códigos de conduta, formas de fiscalização pelo Estado e pela sociedade, constituição e funcionamento dos conselhos, requisitos mínimos para nomeação de dirigentes, entre outros. $\mathrm{O}$ art. $8^{\circ}$ da referida lei apresenta os requisitos de transparência que deverão ser observados, determinando que deverão ser publicadas na internet de forma permanente e cumulativa.

Art. $8^{\circ}$ As empresas públicas e as sociedades de economia mista deverão observar, no mínimo, os seguintes requisitos de transparência:

I - elaboração de carta anual, subscrita pelos membros do Conselho de Administração, com a explicitação dos compromissos de consecução de objetivos de políticas públicas pela empresa pública, pela sociedade de economia mista e por suas subsidiárias, em atendimento ao interesse coletivo ou ao imperativo de segurança nacional que justificou a autorização para suas respectivas criações, com definição clara dos recursos a serem empregados para esse fim, bem como dos impactos econômico-financeiros da consecução desses objetivos, mensuráveis por meio de indicadores objetivos;

II - adequação de seu estatuto social à autorização legislativa de sua criação; III - divulgação tempestiva e atualizada de informações relevantes, em especial as relativas a atividades desenvolvidas, estrutura de controle, fatores de risco, dados econômico-financeiros, comentários dos administradores sobre o desempenho, políticas e práticas de governança corporativa e descrição da composição e da remuneração da administração;

IV - elaboração e divulgação de política de divulgação de informações, em conformidade com a legislação em vigor e com as melhores práticas;

$\mathrm{V}$ - elaboração de política de distribuição de dividendos, à luz do interesse público que justificou a criação da empresa pública ou da sociedade de economia mista;

VI - divulgação, em nota explicativa às demonstrações financeiras, dos dados operacionais e financeiros das atividades relacionadas à consecução dos fins de interesse coletivo ou de segurança nacional;

VII - elaboração e divulgação da política de transações com partes relacionadas, em conformidade com os requisitos de competitividade, conformidade, transparência, equidade e comutatividade, que deverá ser revista, no mínimo, anualmente e aprovada pelo Conselho de Administração; VIII - ampla divulgação, ao público em geral, de carta anual de governança corporativa, que consolide em um único documento escrito, em linguagem clara e direta, as informações de que trata o inciso III;

IX - divulgação anual de relatório integrado ou de sustentabilidade.

[...]

$\S 4^{\circ}$ Os documentos resultantes do cumprimento dos requisitos de transparência constantes dos incisos I a IX do caput deverão ser publicamente divulgados na internet de forma permanente e cumulativa. (BRASIL, Lei $13.303 / 2016$, grifo da autora)

A Lei das Estatais poderá apresentar, em vários aspectos, respostas aos questionamentos dos cidadãos aos procedimentos de negativas na transparência das informações solicitadas. A 
questão será o efetivo compromisso das direções das empresas públicas em implementarem a lei e, do governo e órgãos fiscalizadores, monitorarem esse cumprimento.

\subsubsection{Lei Postal}

Da transformação do DCT na empresa pública de direito privado em 1967 - a ECT, se passaram 11 anos até que uma lei regulamentasse o serviço postal no Brasil. A empresa elaborava suas próprias normativas e as informava aos empregados, quando necessário, através de comunicados internos com a utilização de documentos avulsos ou leitura da chefia à equipe, em reunião semanal, chamadas de "Primeira Hora", ainda em prática na empresa.

A regulamentação se efetivou através da Lei $\mathrm{n}^{0}$ 6.538, de 22 de junho de 1978, que dispõem sobre os Serviços Postais, foi aprovada pelo Congresso Nacional e sancionada pelo então Presidente da República Ernesto Geisel, militar do exército, que no governo anterior havia ocupado a presidência da Petrobrás.

[...] O governo Médici, como se acreditasse poder tudo - em um quadro político em que a oposição militar havia sido aniquilada e a oposição liberal sufocada, enquanto a aliança Estado/Empresa Multinacional/Empresa Privada Nacional parecia dotada de indefinida longevidade em face da generosa colheita de lucros em tempos de auge cíclico -, anuncia a meta de redução da inflação (15\% em 1972, 12\% em 1973), sem admitir qualquer sacrifício em termos de crescimento econômico [...]

[...] O governo Geisel, comprometido com um projeto de liberalização do regime, foi também abalado por um "choque político": a inesperada derrota nas eleições legislativas de novembro de 1974. A partir daí a "política de distensão" ingressaria em uma rota tortuosa, tendo de enfrentar recorrentes desafios de frações internas e apelar para o arsenal de instrumentos discricionários à sua disposição para não descarrilhar. (MACARINI, 2011, p.35 e 40)

Entre o arsenal de instrumentos discricionários Carvalhêdo e Rodrigues (2008, p.4) destacam a atuação do General Ernesto Geisel. Um ano após o término da Guerrilha do Araguaia, através do Decreto 75.657, assinado por ele, onde cria o Sistema de Serviços Gerais - SISG, em 24 de abril de 1975, com a função de disciplinar o uso, a guarda, a conservação, a reprodução e a incineração de processos e documentos, estabelece os órgãos responsáveis por essas atividades e os Ministérios Militares e o Estado-Maior das Forças Armadas são excluídos do Sistema. As autoras ressaltam ainda, que em janeiro de 1977, o general presidente assina o 
Decreto $\mathrm{n}^{\mathrm{o}} 79.099$ mantendo a autorização de eliminação dos documentos considerados sigilosos. O decreto sucessor, de 1994, que permanece em vigor até o momento - o Decreto $\mathrm{n}^{\mathrm{o}}$ 1904 incluiu os Ministérios Militares e o Estado Maior das Forças-Armadas com a opção de usar, não são obrigados, mas as empresas públicas e as sociedades mistas não são se quer citadas na norma legal, ou seja, estão claramente excluídas desde sempre.

A Lei Postal vem, então, para reforçar o papel de exclusividade da ECT no mercado postal num momento em que a violação do monopólio, presente no DL509, começava a ameaçar os negócios da empresa, segundo Teixeira (2013). A possível causalidade entre quebra do monopólio e falência da empresa começou a se tornar um argumento recorrente com a quantidade de denúncias anônimas que surgiam. O então diretor regional da ECT de São Paulo, Coronel Adwaldo Cardoso Botto de Barros, tinha em seu poder uma lista com mais de 20 empresas que estavam atuando na área da Capital, Santos, Campinas e São Bernardo como 'correio paralelo' a serviço de inúmeras firmas, segundo Teixeira.

Nesse sentido, em 1973 a Folha de São Paulo informava em reportagem intitulada Irregularidade na entrega de cartas que "Fiscais da Diretoria Regional da ECT suspenderam todas as atividades da Entregadora Carlos Pereira de Castro - uma das maiores da capital - que, utilizando-se do nome fictício de 'Servbank', realizava o transporte paralelo de correspondências para três bancos".

Interessante destacar que, além da criminalização da violação ao monopólio postal, as denúncias chegavam ao conhecimento da diretoria dos Correios por meio de denúncias anônimas. Isso resultava, como mostra a reportagem, em uma verdadeira investigação policial para combater a violação ao monopólio por parte dos integrantes das forças armadas que administravam a ECT.

[...] Na década de 1970, houve inúmeros incidentes que exemplificam a disputa entre empresas privadas e a ECT, inclusive com possibilidade de prisão para empresários (HABEAS-CORPUS..., 1974). Essa década, portanto, pode ser caracterizada como um período em que a violação ao monopólio era efetivamente um caso de polícia. (TEIXEIRA, 2013, p.35/36)

O monopólio é a exclusividade de exploração de atividade econômica estabelecida pelo Poder Público para si, ou para terceiros, através de instrumentos normativos.

A Constituição Federal do Brasil de 1988 determina que a ordem econômica é fundada na "valorização do trabalho humano e na livre iniciativa" e no artigo 170, tem como um dos princípios a livre concorrência. Ao mesmo tempo em que no artigo 177, lista a relação de monopólios da União, praticamente restrito a questões relacionadas ao petróleo. Ao recuperarmos as competências da União estabelecidas no artigo 21 da CF verificamos que no inciso X há a determinação de "manter o serviço postal e o correio aéreo nacional”, e neste mesmo artigo encontram-se outras competências de grande importância para a nação como: 
declarar a guerra e celebrar a paz; emitir moeda; assegurar a defesa nacional; autorizar e fiscalizar a produção e o comercio de material bélico; o mar; as ilhas; etc. Já o artigo 22 determina ainda sobre quais temas compete privativamente à União legislar e encontramos no inciso $\mathrm{V}$, o serviço postal.

O DL509, como vimos anteriormente, estabelece as competências para a empresa pública, e da mesma maneira, a Lei Postal estabelece quais são os serviços postais explorados pela ECT, monopolisticamente ou não.

Art. $2^{\circ}$ - O serviço postal e o serviço de telegrama são explorados pela União, através de empresa pública vinculada ao Ministério das Comunicações. [...] Art. $7^{\circ}$ - Constitui serviço postal o recebimento, expedição, transporte e entrega de objetos de correspondência, valores e encomendas, conforme definido em regulamento. [...]

Art. $9^{\circ}$ - São exploradas pela União, em regime de monopólio, as seguintes atividades postais:

I - recebimento, transporte e entrega, no território nacional, e a expedição, para o exterior, de carta e cartão-postal;

II - recebimento, transporte e entrega, no território nacional, e a expedição, para o exterior, de correspondência agrupada:

III - fabricação, emissão de selos e de outras fórmulas de franqueamento postal.

$\S 2^{\circ}$ - Não se incluem no regime de monopólio:

a) transporte de carta ou cartão-postal, efetuado entre dependências da mesma pessoa jurídica, em negócios de sua economia, por meios próprios, sem intermediação comercial;

b) transporte e entrega de carta e cartão-postal; executados eventualmente e sem fins lucrativos, na forma definida em regulamento (BRASIL, Lei $\mathrm{n}^{\circ}$ $6.538 / 78$, grifos da autora)

O debate sobre o monopólio postal e a caracterização do serviço postal como um serviço público ou desempenho de uma atividade econômica é a uma das questões de maior importância para que possamos responder ao problema apresentado nesta pesquisa quanto à transparência das informações que a empresa produz e, portanto, dar acesso aos cidadãos.

\subsubsection{A CPMI “dos Correios" e o TAC}


A Comissão Parlamentar Mista de Inquérito (CPMI) dos Correios foi criada, no Congresso Nacional (CN), originalmente para investigar o escândalo dos Correios (2005) que tratava de um "esquema de corrupção". O Relatório Final dessa CPMI "dos Correios", foi apresentado em abril de 2006, e é composto de três volumes com um total de 1.857 (um mil, oitocentas e cinquenta e sete páginas).

O Volume III (BRASIL/CN, 2006) aponta, em vários momentos, o fato da ECT não estar com suas normas internas com a atualização necessária relativo ao aparato normativo em vigor, como no item 10.2 do relatório que trata da Rede Postal Noturna (RPN) que transcrevemos a seguir.

[...] não observaram as formalidades definidas em lei a contratação da Beta nas Dispensas de Licitação 001/2000 e 003/2000, visto que a empresa estava inscrita na Dívida Ativa da União desde meados de 1998, não estando habilitada a contratar com a Administração Pública. A burla à lei supostamente foi autorizada pelo Manual de Licitações da estatal (Manlic), que sugere que a demonstração de regularidade fiscal com o Fundo de Garantia por Tempo de Serviço (FGTS) e com o Instituto Nacional de Seguridade Social (INSS) é suficiente para contratar com a estatal. [...]

[...]. Quanto à súbita contratação da Skymaster para operar as linhas A e C, no âmbito da Dispensa de Licitação $n^{\circ}$ 002/2001, impossível imaginar um procedimento tão breve sem a participação de funcionários dos Correios. É formal e substancialmente impossível efetivar uma contratação tão complexa em apenas um dia. Pois foi esse o exíguo tempo decorrido entre a autorização da contratação por emergência, em 25/06/2001, e a assinatura do contrato com a Skymaster, em 26/06/2001, dia mesmo do início da operação das aeronaves da contratada. Entre esses dois termos, importa registrar que a ECT fez consulta de preços a várias empresas do ramo, que, obviamente, declinaram do contrato por impossibilidade material de atender a demanda de tamanha magnitude em pouco mais de 24 horas. [...] (BRASIL/CN, 2006, p.1588/90, grifos da autora)

Os questionamentos existentes, no Relatório, sobre a rapidez das contratações e a não adequação do manual de licitação à referida lei, demonstra a prática de autonomia exercida na empresa desde a sua criação em 1969, em consequência dos DL200 e DL509. No parágrafo único do artigo $4^{\circ}$ da Lei $n^{\circ}$ 8666/93 (Lei de Licitação) está descrito que “o procedimento licitatório previsto nesta lei caracteriza ato administrativo formal, seja ele praticado em qualquer esfera da Administração Pública". Ou seja, na empresa pública uma contratação tem que cumprir todo o ritual do processo administrativo, com autuação, tramitação, rubrica, assinatura, publicação de edital, divulgação, arquivo, controle, o que não era praticado.

Fonseca (2013) ressalta que dentro do projeto de reforma democrática do Estado brasileiro em discussão na década de 1980, o projeto de lei para os arquivos brasileiros obteve 
destaque, mas a lei só foi promulgada em 1991. A ação do Arquivo Nacional junto aos Constituintes responsáveis pela elaboração da CF resultou na introdução de "referências à gestão arquivística em todos os níveis" (FONSECA, 2013, p.69). Assim a inclusão do art. 216, $\S 2^{0}$ "cabem à administração pública, na forma da lei, a gestão da documentação governamental e as providências para franquear sua consulta a quantos dela necessitem" foi garantida na Constituição Federal o que por si só determinava uma responsabilidade da administração pública.

A Lei de Arquivos, Lei $\mathrm{n}^{\circ} 8.159$, que dispõe sobre a política nacional de arquivos públicos e privados, foi promulgada em 8 de janeiro de 1991, e já no primeiro artigo estabelece a responsabilidade do Poder Público com a gestão documental, a proteção especial a documentos de arquivo e as definições sobre arquivos, gestão de documentos, da publicidade e acesso às informações.

Art. $1^{\circ}$ - É dever do Poder Público a gestão documental e a proteção especial a documentos de arquivos, como instrumento de apoio à administração, à cultura, ao desenvolvimento científico e como elementos de prova e informação.

Art. $2^{\circ}$ - Consideram-se arquivos, para os fins desta Lei, os conjuntos de documentos produzidos e recebidos por órgãos públicos, instituições de caráter público e entidades privadas, em decorrência do exercício de atividades específicas, bem como por pessoa física, qualquer que seja o suporte da informação ou a natureza dos documentos.

Art. $3^{\circ}$ - Considera-se gestão de documentos o conjunto de procedimentos e operações técnicas referentes à sua produção, tramitação, uso, avaliação e arquivamento em fase corrente e intermediária, visando a sua eliminação ou recolhimento para guarda permanente.

Art. $4^{\circ}$ - Todos têm direito a receber dos órgãos públicos informações de seu interesse particular ou de interesse coletivo ou geral, contidas em documentos de arquivos, que serão prestadas no prazo da lei, sob pena de responsabilidade, ressalvadas aquelas cujos sigilo seja imprescindível à segurança da sociedade e do Estado, bem como à inviolabilidade da intimidade, da vida privada, da honra e da imagem das pessoas.

Art. $5^{\circ}$ - A Administração Pública franqueará a consulta aos documentos públicos na forma desta Lei. (BRASIL, Lei $n^{\circ} 8.159,1991$ )

O Título III - Da Organização do Estado, da Constituição Federal no seu Capítulo VII, trata da Administração Pública e no seu primeiro artigo, o art. 37, o caput estabelece que a administração pública direta e indireta deverá “obedecer aos princípios de legalidade, impessoalidade, moralidade, publicidade e eficiência[...]”. O inciso XXI deste artigo, trata das licitações públicas e foi regulamentado em 1993 através da Lei de Licitações, Lei nº 8.666/93, que explicita seu alcance às empresas estatais, se aplicando integralmente à ECT. Esta lei revoga o Decreto-Lei 2.300/1986 e suas alterações, que substituiu o "entulho" do regime militar, inclusive o contido no DL200. 
Art. 1. ${ }^{\text {O. }}$ Esta Lei estabelece normas gerais sobre licitações e contratos administrativos pertinentes a obras, serviços, inclusive de publicidade, compras, alienações e locações no âmbito dos Poderes da União, dos Estados, do Distrito Federal e dos Municípios.

Parágrafo único. Subordinam-se ao regime desta Lei, além dos órgãos da administração direta, os fundos especiais, as autarquias, as fundações públicas, as empresas públicas, as sociedades de economia mista e demais entidades controladas direta ou indiretamente pela União, Estados, Distrito Federal e Municípios. [...]

[...]Art. $4^{\mathrm{o}}$ Todos quantos participem de licitação promovida pelos órgãos ou entidades a que se refere $\mathrm{o}$ art. $1^{\mathrm{o}}$ têm direito público subjetivo à fiel observância do pertinente procedimento estabelecido nesta lei, podendo qualquer cidadão acompanhar o seu desenvolvimento, desde que não interfira de modo a perturbar ou impedir a realização dos trabalhos. (BRASIL, Lei 8666,1993 , grifos da autora)

No processo de modernização da administração pública, em 1999 é promulgada a Lei dos Processos Administrativos - Lei $n^{\circ}$ 9.784, que de acordo com o art. $2^{\circ}$, aplica-se a toda a Administração Pública que deve obedecer, dentre outros, aos princípios "da legalidade, finalidade, motivação, razoabilidade, proporcionalidade, moralidade, ampla defesa, contraditório, segurança jurídica, interesse público e eficiência". Nos critérios enunciados se destacam, no art. $2^{\circ}$, a publicidade dos atos administrativos, o acesso à informação dos interessados, a transparência pública que já estavam previstos no inciso XXXIII do art. $5^{\circ}$ da CF.

[...] Parágrafo único. Nos processos administrativos serão observados, entre outros, os critérios de: [...]

[...] V - divulgação oficial dos atos administrativos, ressalvadas as hipóteses de sigilo previstas na Constituição; [...]

[...] X - garantia dos direitos à comunicação, à apresentação de alegações finais, à produção de provas e à interposição de recursos, nos processos de que possam resultar sanções e nas situações de litígio; [...]

[...] XII - impulsão, de ofício, do processo administrativo, sem prejuízo da atuação dos interessados; [...] (BRASIL, Lei n ${ }^{\circ}$ 9.784, 1999, grifos da autora)

O Inquérito Civil $\mathrm{n}^{\mathrm{o}}$ 1.16.000.000919/2005-09 foi instaurado em função de matéria jornalística com ampla divulgação nacional sobre um "esquema de corrupção" ${ }^{46}$ nos Correios, em 2005. O célebre vídeo apresenta um executivo do quadro efetivo dos Correios aceitando R\$

\footnotetext{
${ }^{46}$ Referente a matéria jornalística publicada pela revista veja, edição $\mathrm{n}^{\circ} 1.905$ - ano 38, de 18 de maio de 2005 , sobre um esquema de corrupção na área de licitações e contratos da Empresa Brasileira de Correios e Telégrafos (texto reproduzido do Termo Aditivo publicado no D.O.U. seção 3 n$^{\circ}$ 165, de 26/08/2011, pag.116)
} 
3.000, 00 (três mil reais) de um empresário que se diz interessado em fazer negócios com a empresa estatal (LEITE, 2013, p.26). Este fato passou a ser nacionalmente conhecido como “Mensalão do Correios". Este inquérito resultou em um Termo de Ajuste de Conduta (TAC) assinado pela ECT e o Ministério Público Federal (MPF) em 21/10/2010, que trata dos procedimentos relacionados à fiscalização, autuação e arquivamento de processos de contratação e de gestão de contratos no contexto da Lei 8.666/93 e da Lei 9.784/99. A cláusula segunda do TAC determinava a necessidade de "Instrução, Autuação e Arquivamento dos documentos da ECT".

O relato do Procurador do Ministério Público Federal é bem revelador da situação documental da empresa quando da apuração durante o inquérito civil.

$\mathrm{Na}$ sequência, foram remetidas duas equipes à Administração Central dos Correios com o escopo de recolherem ao Ministério Público todos os processos de contratação da chamada lista de propina. Lá chegando, depararam-se elas com uma situação documental bastante caótica, o que os obrigou a inventariar os autos das contratações, antes de transferi-los para a guarda do Ministério Público Federal. A execução dessa tarefa consumiu vários dias e culminou com a transferência de dezenas de caixas de documentos que demoraram mais de ano para serem totalmente analisadas. (ACIOLI, 2011, p.1/2, grifo da autora)

Antes da assinatura do TAC a definição dos prazos de guarda dos processos de contratação e de gestão de contratos se orientava pelas Instruções Normativas do Tribunal de Contas da União (TCU), as quais estipulavam os prazos prescricionais específicos para estes documentos, tomando-se por base eventos relacionados à decisão definitiva de julgamento das contas pelo TCU ou da apresentação, pelas unidades jurisdicionadas, dos relatórios de gestão ao TCU. A tabela com os prazos de arquivamento está apresentada na seção 3.1.

No referido Termo assinado pelo MPF e a ECT, entre os onze "considerandos" que antecedem a decisão, verificamos no sétimo, o diagnóstico inicial de como se encontravam a documentação na empresa.

Considerando que os servidores do MPF que cumpriram a diligência, por meio do relatório de informação supra, detectaram "grande quantidade de documentos sem autuação (...), ocorrências de páginas fora de ordem, ausência de cronologia, páginas sem autuação, numeração com rasura, numeração ilegível, páginas com mais de um número, além de outras ocorrências", [...] (ANEXO I, p.2)

Nas últimas três décadas a empresa não conseguiu recepcionar de forma plena a legislação que tratava da gestão documental no país. Não havia, neste período, um plano de 
classificação de documentos e a tabela de temporalidade e destinação de documentos aprovados pelo Arquivo Nacional. Embora as prestações de contas anuais estivessem julgadas pelo TCU e respectivos prazos de guarda documental expirados de forma contínua até o ano de 2000, a eliminação de documentos produzidos permaneceu suspensa até a aprovação pelo Arquivo Nacional do plano e da tabela.

Como relatado por Leonel e Cruz $(2015)^{47}$ a situação anterior ao NUP e GDC era da inexistência de padrão de procedimento de gestão documental

Até 2011, os Correios não possuíam procedimentos estruturados de gestão documental. A empresa carecia de mudanças fundamentais, tais como: revisão dos preceitos normativas sobre gestão documental e formação de processos administrativos, implantação de sistema corporativo de gestão de documentos, implantação de protocolo único, adoção de numeração única de processos.

Como consequência observam-se diversos problemas, tais como:

1)Dispersão dos documentos produzidos em virtude de tramitarem de forma independente (avulsa).

2)Tratamento simultâneo do mesmo assunto em vários órgãos;

3)Falta de controle sistematizado dos documentos produzidos.

4)Dificuldade no acesso à informação.

A ausência de procedimentos estruturados de gestão documental compromete o processo decisório, a racionalização e a obtenção de economia e eficiência nos procedimentos gerenciais de informações organizacionais. Em última instância perde sua memória. (LEONEL; CRUZ, 2015, p.4)

A partir do dia 29 de dezembro de 2010 todos os órgãos e profissionais da ECT envolvidos com as atividades de contratação, de gestão administrativa e operacional de contratos, autuação e arquivamento dos respectivos processos foram orientados sobre a adoção de medidas necessárias, com foco no cumprimento do referido TAC, dentre as quais, especificamente sobre os novos prazos de arquivamento dos documentos. A ação envolveu $40 \%$ da força de trabalho administrativa, uma vez que os demais trabalhadores atuam diretamente com os usuários e clientes na venda de serviços, entrega de objetos, ou no seu manuseio.

O Ministério Público Federal, definiu como prazo para guarda dos documentos, referentes aos contratos firmados com valor determinado e os relatórios de Gestão, o período de 10 anos, a contar da assinatura do Termo.

Cláusula 1 1': designação de fiscais (art. 67, Lei nº . 8.666/93);

\footnotetext{
${ }^{47}$ Leonel e Cruz (2015) são duas arquivistas que ingressaram na ECT após 2011 e apresentaram a mudança de paradigmas nos Correios no $12^{\circ}$ Congresso Nacional da BAD - Associação Portuguesa de bibliotecários, arquivistas e documentalistas. $\mathrm{O}$ artigo publicado pelas duas é utilizado como referência.
} 
Cláusula $2^{\mathbf{a}}$ : instrução, autuação e arquivamento de processos de licitação e gestão de contratos (art. 38 e 60 da Lei $n^{\circ}$. 8.666/93 e art. $22 \S 4^{\circ}$ da Lei $n^{\circ}$. 9.784/99);

Cláusula $3^{\text {a }}$ : Em todas as contratações, centralizadas ou não, de valor global superior a R\$ 1,5 milhão, cujos contratos já se encontrem formalmente encerrados na data da assinatura do TAC (21/10/2010), a ECT providenciará a guarda em local com acesso controlado, pelo prazo de 10 (dez) anos, contados da assinatura deste Termo.

Parágrafo único - os processos serão guardados em seu atual estágio de organização mantendo-se a sua integridade;

Cláusula $4^{\text {a }}$ : a ECT compromete-se a manter arquivado, por 10 (dez) anos, contados a partir da apresentação dos Relatórios de Gestão ao TCU, referentes ao ano de encerramento do contrato, todos os processos administrativos atinentes à licitação e à gestão de contratos.

Parágrafo Único - a ECT compromete-se a não expurgar quaisquer documentos relacionados aos processos de contratação sob investigação do MPF, TCU, CGU e PF ou que estejam sub judice, sempre que nesse sentido receber recomendação ou solicitação dos órgãos interessados ou então tiver ciência, formal, da existência de investigações, ações judiciais e/ou procedimentos de controle. (ANEXO I, p.4/5, grifo da autora)

Sob a coordenação do MPF, CGU e ECT foi realizada no dia 5 de julho de 2011, no Auditório JK da Procuradoria Geral da República/PGR-MPF, a "Audiência Pública sobre Gestão Eletrônica de Documentos - Desafios e Perspectiva (Inquérito Civil no 1.16.000.000919/2005-09)" (BRASIL/CGU, 2011 ). Composto de quatro painéis envolvendo a legislação que tratava da gestão eletrônica de documentos tanto no setor público como no setor privado; a gestão eletrônica de documentos como ferramenta na realização das atividades dos órgãos de controle, experiências do MPF e de entidades da sociedade civil; marco regulatório para certificação digital no Brasil, questões tecnológicas e segurança no ambiente de trabalho e a concepção organizacional, políticas e práticas de segurança com requisitos de integridade, autenticidade, valor probatório.

Quadro 3 - Temas da Audiência Pública

\begin{tabular}{|l|l|}
\hline Painéis da Audiência Pública & Órgãos convidados \\
\hline $\mathbf{1}^{\mathbf{0}}$ Painel: Gestão Arquivística & SLTI/MPOG \\
Eletrônica de Documentos e & Arquivo Nacional/ Projeto InterPARES \\
debate correspondente & Marinha do Brasil \\
& Superior Tribunal de Justiça - \\
& Receita Federal do Brasil - RFB \\
\hline
\end{tabular}




\begin{tabular}{|l|l|}
\hline $\begin{array}{l}\mathbf{2}^{\mathbf{0}} \text { Painel: A importância da } \\
\text { Gestão Documental nas Ações de } \\
\text { Controle e debate correspondente }\end{array}$ & $\begin{array}{l}\text { MPF } \\
\text { CGU } \\
\text { Tribunal de Contas da União } \\
\text { ONG Contas Abertas }\end{array}$ \\
\hline $\begin{array}{l}\mathbf{3}^{\mathbf{0}} \text { Painel: Segurança da } \\
\text { informação e debate } \\
\text { correspondente }\end{array}$ & $\begin{array}{l}\text { Instituto de Tecnologia da Informação -ITI } \\
\text { Gabinete de Segurança da Informação - GSI } \\
\text { Receita Federal do Brasil - RFB } \\
\text { Instituto dos Auditores Internos do Brasil - IIA } \\
\text { Brasil }\end{array}$ \\
\hline
\end{tabular}

$4^{\mathbf{0}}$ Painel: Integridade, autenticidade e valor probatório dos documentos e debate correspondente

Conselho Nacional de Justiça - CNJ SERPRO

Banco Central do Brasil Caixa Econômica Federal

Fonte: elaborado pela autora com base na programação do evento ${ }^{48}$

A audiência pública teve como objetivo estimular as ações que vieram a se concretizar com instalação de um grupo de estudos e depois, em setembro de 2011, no Grupo de Trabalho para implantação da solução na empresa, de forma a instituir os procedimentos para autuar, numerar, controlar, tramitar e arquivar processos na ECT.

A assinatura do TAC impulsionou a discussão na empresa da necessidade de adoção de uma política de gestão documental, que passava pela aplicação da Lei de Arquivos - Lei 8159/1991. O prazo para o cumprimento do TAC, após prorrogação de 120 dias $^{49}$, foi o dia 26/12/2011, e a nova sistemática de gestão documental da empresa aderente à política de gestão transparente e eficiente foi implementada, como veremos no capitulo 3.

Em 2014, em resposta por transparência passiva à um cidadão que solicitou informações sobre como foram concluídas as investigações sobre o "Mensalão", a empresa informa que "não foi constatado valor desviado da estatal", mas que atos praticados por empresas contratadas à época teriam lesado a ECT e que há processos disciplinares.

\section{4}

Detalhamento:

Gostaria de saber, em relação ao caso mensalão que ocorreu nos Correios, se houveram demissões de servidores da empresa? Se sim, quais? Ainda se houve algum dinheiro estatal desviando? Se sim? Foram devolvidos? Quanto? Existe processos internos referente ao caso mensalão atualmente? Se sim, quais?

Resposta da ECT:

\footnotetext{
${ }^{48}$ Disponível em <http:/www.cgu.gov.br/sobre/institucional/eventos/anos-anteriores/2011/audiencia-publicasobre-gestao-eletronica-de-documentos/programacao.pdf $>$

49 Termo Aditivo publicado no D.O.U. seção 3 n 165, de 26/08/2011, pag. 116.
} 
Informamos que todas as denúncias relacionadas ao caso do Mensalão, envolvendo empregados desta Empresa Pública foram apuradas, em conformidade às normas sobre a matéria. Os trabalhos foram acompanhados pela Controladoria Geral da União e Ministério Público Federal.

Em decorrência do apurado, ocorreram 12 (doze) demissões. A empresa está impossibilitada de divulgar os nomes dos ex-empregados tendo em vista tratar-se de informação de cunho pessoal, sendo sua divulgação vedada pela própria Lei de Acesso à Informação em seus artigos $6^{\circ}$, inciso III e 31, pois possui acesso restrito.

Quanto aos valores envolvidos, não foi constatado valor desviado da estatal. No entanto, em decorrência de atos praticados por empresas contratadas à época, foram adotadas providências judiciais visando cobranças de valores na ordem de R\$1.667.571,08.

$\mathrm{Na}$ presente data existem ainda em andamento dois processos que tiveram origem no Mensalão, processos NUP 53101.005366/2013-26 e NUP 53101.007297/2012-12, de natureza disciplinar, portanto, de caráter restrito.

Os Correios agradecem a sua compreensão

Chefe do Departamento de Controle Disciplinar (ANEXO III, p. 1/2)

\subsubsection{Caráter Híbrido da ECT}

O debate sobre o caráter hibrido da ECT passa pela discussão da atuação do Estado na ordem econômica enquanto empresa pública. Se o serviço postal assume a forma de um serviço público - inerente ou por opção político-normativa - ou, se se trata do desempenho de uma atividade econômica.

Alguns técnicos da CGU, utilizaram em seus pareceres as teses do então jurista e Professor Luís Roberto Barroso, Ministro do Supremo Tribunal Federal desde 2013, em que defende claramente que o serviço postal não é um serviço público inerente.

A realidade demonstra que, em todo o mundo, a prestação de serviço postal não pressupõe o exercício de um poder estatal: muitos Estados não the atribuem a qualidade de serviço público e outros sequer prevêem essa modalidade de intervenção do Estado na economia. Com efeito, ninguém é capaz de imaginar, na realidade atual, que o serviço postal só possa ser prestado pelo Estado ou que decorra de alguma de suas funções básicas. $\mathbf{O}$ serviço postal, portanto, não é, definitivamente, um serviço público inerente. Resta saber se o direito objetivo brasileiro, por uma opção políticonormativa, atribui ao serviço postal tal qualidade. Também aqui a resposta é negativa. A ordem jurídica anterior à Constituição de 1988 não considerava o

\footnotetext{
${ }^{50}$ No ANEXO III constam a autorização para divulgação do requerente e o relatório do NUP com a pergunta e resposta da empresa.
} 
serviço postal como serviço público - ao menos desde a década de 60 - e também a nova Carta assim não o consagrou.

Como já referido, o serviço postal pode ter sido considerado um serviço público no passado, em razão principalmente da falta de capacidade ou interesse da iniciativa privada nesse empreendimento, mas já de algum tempo evoluiu para uma atividade econômica. $O$ marco legal dessa alteração histórica na natureza do serviço postal brasileiro foi a transformação do Departamento de Correios e Telégrafos - DCT, em 1968, em empresa pública, à qual competia, nos termos do Decreto-lei 509, de 20/03/1969, a execução e controle, em regime de monopólio dos serviços postais. (BARROSO, 2000, p.202/203)

Em 2009, o tema foi objeto de decisão do Supremo Tribunal Federal no julgamento da Arguição de Descumprimento de Preceito Fundamental 46 (ADPF 46), na qual a Associação Brasileira das Empresas de Distribuição reclamava o direito das transportadoras privadas fazerem entregas de encomendas. A corrente que prevaleceu na votação ocorrida no Plenário do Supremo foi sustentada pelos ministros Eros Grau, que redigiu o acórdão, Ellen Gracie, Cármen Lúcia, Joaquim Barbosa, Cezar Peluso e Carlos Ayres Britto. Os que haviam votado pela quebra do monopólio dos Correios em encomendas, mas também em cartas comerciais, foram os ministros Celso de Mello, Gilmar Mendes e Ricardo Lewandowski. Já o relator, ministro Marco Aurélio, votou pela completa quebra do monopólio dos Correios. Então, por seis votos a quatro, o Plenário do Supremo Tribunal Federal (STF) declarou que a Lei 6.538/78, que trata do monopólio dos Correios, foi recepcionada e está de acordo com a Constituição Federal de 1988.

Com isso, cartas pessoais e comerciais, cartões-postais, correspondências agrupadas (malotes) só poderão ser transportados e entregues pela empresa pública ECT. Por outro lado, o Plenário entendeu que as transportadoras privadas, não cometem crime ao entregar outros tipos de correspondências e encomendas.

1.O serviço postal --- conjunto de atividades que torna possível o envio de correspondência, ou objeto postal, de um remetente para endereço final e determinado --- não consubstancia atividade econômica em sentido estrito. Serviço postal é serviço público.

2.A atividade econômica em sentido amplo é gênero que compreende duas espécies, o serviço público e a atividade econômica em sentido estrito. Monopólio é de atividade econômica em sentido estrito, empreendida por agentes econômicos privados. A exclusividade da prestação dos serviços públicos é expressão de uma situação de privilégio. Monopólio e privilégio são distintos entre si; não se os deve confundir no âmbito da linguagem jurídica, qual ocorre no vocabulário vulgar.

3.A Constituição do Brasil confere à União, em caráter exclusivo, a exploração do serviço postal e o correio aéreo nacional (artigo 20, inciso X). 
4.O serviço postal é prestado pela Empresa Brasileira de Correios e Telégrafos - ECT, empresa pública, entidade da Administração Indireta da União, criada pelo decreto-lei $\mathrm{n}^{\circ} 509$, de 10 de março de 1.969 .

5.É imprescindível distinguirmos o regime de privilégio, que diz com a prestação de serviços públicos, do regime de monopólio sob o qual, algumas vezes, a exploração de atividade econômica em sentido estrito é empreendida pelo Estado.

6.A Empresa Brasileira de Correios e Telégrafos deve atuar em regime de exclusividade na prestação dos serviços que lhe incumbem em situação de privilégio, o privilégio postal.

7.Os regimes jurídicos sob os quais em regra são prestados os serviços públicos importam em que essa atividade seja desenvolvida sob privilégio, inclusive, em regra, o da exclusividade.

8.Arguição de descumprimento de preceito fundamental julgada improcedente por maioria. O Tribunal deu interpretação conforme à Constituição ao artigo 42 da Lei $n^{\circ} 6538$ para restringir a sua aplicação às atividades postais descritas no artigo $9^{\circ}$ desse ato normativo. (BRASIL/STF, 2010, p.22, grifo da autora)

O voto do Ministro Carlos Ayres Britto é extremamente elucidativo quanto as diferenças de concepção do serviço postal e da importância das garantias do inciso X do artigo $5^{\circ}$ da Constituição Federal que garante que são invioláveis a intimidade, a vida privada, a honra e a imagem das pessoas - o que traz ao debate a questão dos dados pessoais ainda não regulamentado pela Lei de Acesso à Informação - e por isso um serviço público, cujo o protagonista deve ser exclusivamente a União.

[...] Entre caracterizar o serviço postal e o Correio Aéreo Nacional enquanto modalidades de atividades econômicas ou de serviço público, manifestei-me pela segunda opção. Entendo que essas atividades são de serviço público, porém de serviço público de logo reservado à competência da União.

A Constituição diz que são atividades próprias da União, típicas da União, encarregada a União de mantê-las, a caracterizar, portanto, uma compulsoriedade de prestação. Além de ser um serviço público, típico da União, não pode deixar de ser prestado, daí a Constituição fazer uso do verbo "manter". [...]

[...], parece-me não ser passível de transpasse para a iniciativa privada, mediante os conhecidos institutos da autorização, da concessão ou da permissão, vale dizer até - não estou sendo exagerado ao assim asseverar que é o único serviço público não passível de transpasse para a iniciativa privada, mediante os citados institutos. [...]

[...] E qual seria a razão, a finalidade de a Constituição tratar a matéria por uma forma tão diferenciada? Essa especificidade decorreria da destinação das atividades que estamos a falar: favorecer a comunicação privada entre pessoas, a integração nacional e o sigilo da correspondência. Que correspondência? Correspondência epistolar e telegráfica, porque essas são cercadas, pelo inciso $\mathrm{X}$ do artigo $5^{\circ}$ da Constituição, de cautelas especiais, ou seja, recai sobre elas a inviolabilidade. Constituição quer invioláveis a correspondência epistolar e a comunicação telegráfica, por isso reservou tais atividades para esse senhorio exclusivo e protagonização também exclusiva da União. [...] (BRASIL/STF, 2010 p.111, grifo da autora) 
Segundo Bento e Bringel (2014, p.369) os estudiosos de Direito Administrativo ensinam que todas as entidades da Administração Pública se encontram vinculadas à satisfação de algum aspecto do interesse público, definido na lei que autorizou a sua criação.

\begin{abstract}
Mesmo as entidades dotadas de personalidade jurídica de direito privado, onde se enquadram as empresas públicas e as sociedades de economia mista, não fogem totalmente ao regime jurídico do direito público. A lei autoriza a criação de empresas públicas e sociedades de economia mista com personalidade jurídica de direito privado a fim de servir-se dos meios de atuação próprios do setor privado e do direito comum que lhe é inerente. Porém, conforme Maria Sylvia Zanella Di Pietro ressalta, nenhuma entidade estatal se sujeita inteiramente ao direito privado. Seu regime será híbrido, ou misto, isto é, parcialmente de direito privado e parcialmente de direito público. Em razão disso, mesmo as empresas públicas e sociedades de economia mista exploradoras de atividade econômica, embora equiparadas às empresas privadas no que diz respeito às obrigações civis, comerciais, trabalhistas e tributárias, em face do art. $173, \S 1^{\circ}$, II da Constituição, estão sujeitas aos controles especiais próprios das espécies administrativas, tais como a obrigação de prestar contas, a obrigação de realizar licitação e concurso público, entre outros (DI PIETRO, 2013, p. 485). Assim, o mero fato de explorar atividade econômica não autoriza o afastamento total da aplicação do princípio da publicidade e da Lei de Acesso a Informação. (BENTO E BRINGEL, 2014, p.369, grifo da autora)
\end{abstract}

A CGU adota o entendimento de que as empresas públicas, as sociedades de economia mista, e suas subsidiárias, não estão obrigadas a atender aos pedidos de informação solicitados pelo cidadão quando esta informação está relacionada com a estratégia empresarial, que possa interferir na competitividade da empresa. A ideia é de que existem para competir no mercado em igualdade de condições com as empresas privadas, em nome do Estado brasileiro.

Bento e Bringel (2014, p.380) na análise das decisões da CGU revelaram a ocorrência de abusos, uma vez que muitas empresas usaram por diversas situações valer-se da sua natureza jurídica de instituição financeira de direito privado para negar acesso às informações sobre suas operações. Os autores destacam, ainda, o fato de que as empresas estatais "são utilizadas como moeda de troca de governabilidade". Nesse contexto, "a transparência de suas operações e seus beneficiários é a maior arma de que dispõe a sociedade para coibir a captura por grupos de interesse políticos e econômicos" (Ibid, p.381).

$\mathrm{Na}$ apresentação dos dois casos em destaque, de pedidos de informação aos Correios, abordaremos de novo este tema. 


\section{A ORGANIZAÇÃO DA INFORMAÇÃO NA ECT}

Em 1985, o Arquivo Nacional publicou um manual técnico sob o título "Orientação para avaliação e arquivamento intermediário em arquivos públicos”, do qual constam diretrizes gerais para a realização da avaliação e para a elaboração de tabelas de temporalidade. Posteriormente, em 1986, iniciaram-se as primeiras atividades de avaliação dos acervos de caráter intermediário sob a guarda da, então, Divisão de Pré-Arquivo do Arquivo Nacional, com a preocupação de estabelecer prazos de guarda com vista à eliminação e, consequentemente, à redução do volume documental e racionalização do espaço físico.

A organização e o acesso aos documentos públicos sempre estiveram presentes para os que defendem a importância da memória institucional e coletiva de um povo. No período de 1964 a 1985 o Brasil passou por momentos de obscurantismo e pela falta de liberdade e somente no decorrer da década de 1980 é que os primeiros passos na democratização do país foram dados. A Constituição Federal promulgada em 1988 foi um marco importante na garantia de conquistas sociais aos brasileiros, tendo no art. 216, em seu parágrafo segundo, estabelecido a responsabilidade da administração pública sobre a gestão da documentação governamental e as providências para franquear sua consulta a quantos dela necessitassem. A gestão documental e o direito ao acesso a informação são, portanto, destacados como conquistas deste período.

A Lei $n^{\circ} 8.159$, de 8 de janeiro de 1991, é a regulamentação desta conquista constitucional, que dispõe sobre a política nacional de arquivos públicos e privados e é aprovada no contexto da gestão documental no Brasil. Entretanto, a estrutura dos Correios não internalizou de forma plena esses instrumentos, como apresentamos no item 2.2.4, que trata da CPMI “dos Correios" e o TAC. Analisaremos a seguir a gestão documental da ECT antes de 2011, prazo para o cumprimento do TAC com o MPF. Em sequência, apresentaremos a nova sistemática de gestão documental adotada e que acontece em paralelo à aprovação da LAI pelo Congresso Nacional.

\subsection{A Gestão Documental antes de 2011}

No item 2.2.4 deste estudo, apresentamos a situação em que se encontrava a documentação da ECT quando da apuração do inquérito civil em 2005, que levou à assinatura do TAC. 
Segundo o que apuramos em conversas com gestores da empresa ${ }^{51}$ houve uma descontinuidade da gestão de documentos na ECT. No decorrer da década de 1980 a empresa adotou os conceitos de formação de processos. Entretanto, por alguma razão, desconhecida dos profissionais, estes procedimentos "se perderam no tempo", como nos foi relatado.

Miranda (1999), na exposição da metodologia adotada em sua pesquisa, apresenta as dificuldades vivenciadas para a localização e identificação das informações necessárias, fazendo com que buscasse diretamente junto aos profissionais, as informações desejadas.

A dificuldade na localização e identificação de tais informações deuse, principalmente, aos seguintes fatores:

a)A ECT não dispõe de acervo técnico que contemple projetos, estudos ou outros instrumentos que indiquem a gênese das ações estratégicas implementadas na Empresa;

b)A documentação existente está organizada sem indexação que possibilite ao pesquisador a localização ágil e direta de informações;

c)As informações, muitas vezes, já se apresentavam consolidadas formando conhecimento explícito sobre o assunto, sendo necessário decompor tal conhecimento em informações constitutivas;

d)As informações apresentavam características que as encaixavam em mais de um tipo proposto, sendo que optou-se por classificá-las segundo a característica mais relevante para a ação estratégica considerada;

e)A dificuldade apresentada em "a" obrigou o pesquisador a buscar, junto a profissionais com experiência nas áreas relacionadas à ação estratégica, a informação que lhe desse suporte. (MIRANDA, 1999, p.57)

Teixeira (2014, p.ix) outro pesquisador em que o objeto do estudo envolve a ECT, presente em nossa revisão de literatura, nos agradecimentos de sua tese de doutorado, faz a seguinte declaração: "Não posso citar nominalmente meus antigos colegas de trabalho por ainda estarem na empresa e pelo sigilo necessário aos envolvidos na pesquisa [...]”.

Neste contexto, procuramos, por meio de consulta a empregados que teriam ocupado atividades nas secretarias de Departamento e Vice-Presidências, obter alguma orientação sobre as mudanças na gestão documental naquele período, uma vez que não foram localizados documentos que justificassem a interrupção da organização processual na empresa.

A ECT é uma empresa pública com regime de trabalho CLT e nessas empresas é muito comum a existência periódica de Programas de Demissão Voluntária. Com isso, um conjunto valioso de empregados, com a memória institucional da empresa, desaparece sem nenhum

\footnotetext{
${ }^{51}$ Durante a coleta de dados para esta pesquisa solicitamos à Gerencia de Processos de Gestão Documental (GDOC) um relato sobre as condições da gestão de documentos na ECT. Recebemos um informativo bem detalhado, mão não obtivemos autorização para divulga-lo como Apêndice e fonte de informações. Este documento afirma que houve descontinuidade na gestão de documentos na empresa.
} 
planejamento organizacional, e sem a necessária gestão do conhecimento acumulado. Portanto, não foi trivial identificar empregados que pudessem contribuir nesse resgate histórico. A tese mais plausível é a de que durante as décadas de 1980 e 1990 algumas consultorias foram contratadas para a modernização da empresa e foi introduzido um modelo de gestão em que deveriam deixar as mesas limpas, sem papel. Com isso, documentos foram eliminados sem nenhum tipo de avaliação e coordenação. $\mathrm{O}$ arquivamento dos documentos passou a ser realizado separando-os apenas por "recebido" e "expedido", e não por assunto. Os documentos encaminhados para o arquivo, na sua maioria, eram referentes às áreas de pessoal e financeira, de fiscalização do TCU.

A ECT, como empresa pública, tem autonomia para definir suas próprias normas de funcionamento. O Estatuto da empresa é estabelecido por meio de decreto presidencial, em que se estabelece o arcabouço jurídico, administrativo e financeiro da entidade. Os procedimentos e limites de atuação de cada área são definidos pelos Manuais que são discutidos pela área, ou áreas envolvidas, e passa pelo Departamento de Planejamento (DPLAN), antes de aprovação no colegiado da diretoria executiva. Esse procedimento muda em função da diretoria em exercício $^{52}$ de toda forma é uma decisão no âmbito da empresa, sem publicação em Diário Oficial, e é comunicada pelos meios de comunicação eletrônica na rede interna.

Pelo exposto, também não foi possível identificar as justificativas para emissão, em 25 de maio de 1992 do capítulo 3, módulo 7 do Manual de Comunicação - MANCOM 7/3 ${ }^{53}$ (Anexo IV), que trata de Arquivamento. É possível que tenha se tratado de uma regulamentação interna da Lei de Arquivos, que fora aprovada em 1991, mas não há no manual nenhuma referência à lei. O capítulo trata dos prazos de arquivamento/classificação e constam, ainda, 20 anexos, com o prazo de arquivamento dos documentos para cada área da empresa.

No MANCOM 7/3 estava determinado como prazo mínimo de 1(um) mês, os documentos do Grupo L, e o máximo de 24 (vinte e quatro) meses de arquivo, no órgão produtor dos documentos. Apenas as categorias D e C têm guarda de 60 (sessenta) meses, ou seja, 5 (cinco) anos, e as categorias B e A, guarda permanente no Arquivo Central. Nos 20 anexos ${ }^{54}$

\footnotetext{
52 As mudanças na composição de diretoria, as vezes acarretam em mudanças, aprovadas na Reunião de Diretoria (REDIR) no fluxo de decisão da empresa (informação pessoal).

${ }^{53} \mathrm{Na}$ empresa a forma de abreviação e identificação dos Manuais é utilizar a sigla e colocar o número do modulo barra o número do capítulo, assim MANCOM 7/3 se refere ao Manual de Comunicação, módulo 7, capítulo 3.

${ }^{54}$ Os 20 anexos estão distribuídos da seguinte forma: 1 - todos os órgãos da empresa; 2 - Presidência; 3 - VicePresidência; 4 - Planejamento; 5 - Relações Internacionais; 6 - Operações; 7 - Sistemas e Telemática; 8 Administração de Recursos Humanos; 9 - Treinamento e Desenvolvimento; 10 - Relações de Trabalho; 11 Auditoria e Inspeção; 12 - Jurídica; 13 - Comercial; 14 - Finanças; 15 - Comissão Permanente de Licitação; 16
} 
consta uma relação de códigos, nomes dos documentos e o respectivo grupo ao qual cada um pertence, de A à L, possibilitando, assim, identificar os prazos de arquivamento dos documentos. De forma padronizada, a empresa criava os seus formulários específicos para cada situação. Cada formulário criado recebia um código. O item 5.1 do MANCOM 7/3, destaca que "uma vez preenchidos constituem-se documentos, devem conter o prazo de arquivamento". Entretanto, não havia sistema de controle, e segundo relato dos empregados, não houve capacitação dos empregados para sua utilização ${ }^{55}$.

O controle da informação corporativa, na ECT, passa também pela forma como os manuais da empresa são produzidos e geridos. A maioria dos empregados desconhece o inteiro teor de todos eles, cristalizando a existência de um núcleo restrito de pessoas com o domínio das normas, e com isso exercendo o poder na instituição (informação pessoal) ${ }^{56}$. Diferente da prática legislativa em que se produz uma nova norma, com nova numeração, em caso de qualquer alteração na norma vigente, nos Correios os manuais mantêm sua numeração e a página, que sofre a alteração, é identificada com a data da modificação e uma legenda ao lado do item modificado. O MANCOM é um exemplo e pode se verificar este procedimento através do cabeçalho e das laterais. Este procedimento dificulta a compreensão das mudanças ocorridas e reflete-se na insegurança da aplicabilidade das normas pelos empregados.

Na tabela a seguir apresentamos uma síntese após análise do Anexo 20, como exemplo, que trata dos "Prazos de Arquivamento dos Documentos das Unidades Operacionais" (ANEXO IV), que consta de 11(onze) páginas e lista 219 códigos de documentos, em que apenas 13 (treze) estão nos Grupos de A à D.

Quadro 4 - "Prazos de Arquivamento" - Grupos de A à D - ECT

- Engenharia e Manutenção; 17 - Administração; 18 - Transporte; 19 - Filatelia e Produtos e 20 - Unidades Operacionais.

55 Na implantação da Nova Sistemática de Gestão Documental esta autora atuou como Instrutora na Capacitação dos empregados responsáveis pela gestão dos documentos correntes das diversas áreas da empresa, e junto à Universidade Corporativa dos Correios foi destacado que era a primeira vez que atividades de capacitação envolvendo gestão de documentos era praticada na empresa.

${ }^{56}$ Informação fruto da observação e atuação da autora durante cinco anos e três meses na empresa. 


\begin{tabular}{|c|c|c|}
\hline CÓDIGO & DOCUMENTO & GRUPO \\
\hline $75100030-2$ & DADOS CADASTRAIS & A \\
\hline $75160041-5$ & FICHA DE ENDERECO TELEGRÁFICO(CCE) & B \\
\hline $75170558-6$ & FICHA DE ENDERECO TELEGRÁFICO & $\mathrm{B}$ \\
\hline $75150083-6$ & GUIA DE MOV. PRODUTOS(PEQ.) & $\mathrm{C}$ \\
\hline $75150122-0$ & BALANCETE DE AGÊNCIA - A5 & $\mathrm{C}$ \\
\hline $75250120-8$ & GUIA DE REMESSA DE PRODUTOS & $\mathrm{C}(*)$ \\
\hline $75250426-6$ & COMPROVANTE & $\mathrm{C}$ \\
\hline $75100027-2$ & FICHA INDIV. DE FREQÜENCIA & $\mathrm{D}$ \\
\hline $75100048-5$ & $\begin{array}{l}\text { HORÁRIO DE TRABALHO EXTERNO, FICHA } \\
\text { INDIVIDUAL (CCE) }\end{array}$ & $\mathrm{D}$ \\
\hline $75100067-1$ & CARTÕES DE PONTO & $\mathrm{D}$ \\
\hline 75170557-8 & CARTA TELEGRAMA SEM PAUTA- NAC. & $\mathrm{D}$ \\
\hline $75170557-8$ & CARTA TELEGRAMA SEM PAUTA- INTERNA & $\mathrm{D}$ \\
\hline $75250075-9$ & BOLETIM DE VERIFICAÇÃO C-16 & $\mathrm{D}$ \\
\hline
\end{tabular}

Fonte: elaborado pela autora com base no MANCOM 7/3

O processo de eliminação do MANCOM 7/3, não tinha a devida autorização da instituição arquivística como determina a Lei ${ }^{0}$ 8.159/1991. Segundo a GDOC/DEGSS ${ }^{57}$ (ANEXO II), a definição dos prazos de guarda dos "processos" de contratação e de gestão de contratos se baseava nas orientações presentes nas Instruções Normativas do Tribunal de Contas da União (TCU), que estipulavam prazos prescricionais específicos para estes documentos. A decisão definitiva de julgamento das contas pelo TCU, ou a apresentação dos relatórios de gestão, definiam esse limite.

A circulação de documentos na ECT se concretizava a partir do uso de poucos tipos documentais, apesar da existência de inúmeros modelos de formulários nos manuais. Os documentos mais utilizados eram: a CT - Carta, de uso da empresa para seus empregados; a CI - Comunicação Interna e CI - Circular, utilizada praticamente em todas as comunicações e o Ofício, de uso da empresa para outros órgãos externos. A CI era enviada de um setor ao outro de forma avulsa, este setor, para dar prosseguimento ao solicitado nesta CI, produzia uma nova CI e indicava o número da CI anterior como referência, sem anexá-la, e assim seguia. A numeração destes documentos era realizada por controle manual, ou planilha de excel, de cada CAD - Coordenação Administrativa (existente na Presidência, Vice-presidências e

\footnotetext{
${ }^{57}$ GDOC/DEGSS - Gerencia Corporativa de Processos de Gestão Documental do Departamento de Gestão da Cadeia de Suprimentos e Serviços Gerais. Este Departamento e gerencia foram criados em fevereiro de 2012, após reestruturação da Vice-Presidência de Administração, e implantação do GDC e NUP.
} 
Departamentos) ou SEAD (Seção Administrativa nas Diretorias Regionais). O Sistema de Gestão de Documentos Correntes - GDC, era um software desenvolvido na Diretoria Regional do Paraná que permitia gerar um número para o documento, o que dava uma segurança de que não haveria mais de um documento com o mesmo número e registrava dia, hora e responsável pela emissão do documento. Entretanto, como não era corporativo, ou seja, não era adotado para toda a empresa, seu uso era opcional, e poucas áreas na empresa faziam uso desse "sistema". Portanto, as CIs tramitavam como documentos avulsos, uma se referenciando na anterior que, como um telefone sem fio, seguiam pela empresa, e ao final a informação poderia não ser plenamente confiável. No caso da concretização de alguma aquisição, os documentos sobre o assunto eram reunidos, em pastas estilo registradores com lombada grossa, de forma inversa à aquela padronizada nos processos administrativos, ou seja, o início da demanda era a última folha. Esse "processo" não possuía numeração contínua, com paginação crescente, nem rubrica do responsável, e alguns sem assinatura.

Figura 4 - Sistemática anterior (até 2011)

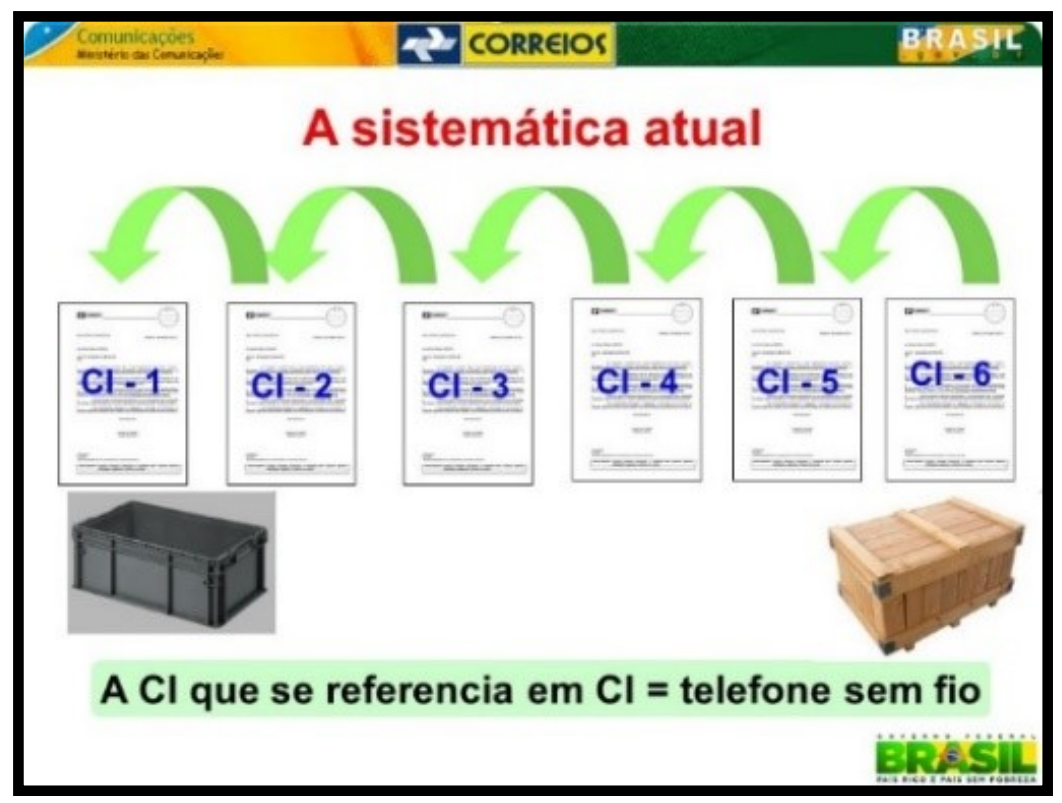

Fonte: elaborado pela autora ${ }^{58}$

Desta forma, a ação do Ministério Público Federal, em 2005, foi firme na determinação de "instrução, autuação e arquivamento de processos de licitação e gestão de contratos" e em

\footnotetext{
${ }^{58}$ O esquema presente na Figura 6 faz parte do Curso de Capacitação dos empregados para adoção da Nova Sistemática de Gestão Documental da ECT aplicado em 2011 e 2012.
} 
suspender a eliminação de qualquer documento. Esta questão foi objeto das Cláusulas $3^{\mathrm{a}}$ e $4^{\mathrm{a}}$ do TAC (ANEXO I) que impôs um prazo de 10 (dez) anos para o arquivamento e determinou a busca de soluções definitivas para a gestão documental.

Já a Cláusula $2^{\mathrm{a}}$ do TAC, após a solicitação de segunda prorrogação, tinha como prazo de cumprimento o dia 20 de dezembro de 2011, no âmbito da Administração Central, e 20 de abril de 2012, em todas as Diretorias Regionais do país. Inicialmente foi instituído um primeiro grupo de trabalho, através da Portaria PRT/VIPAD nº 3/2011, de 30 de junho, com o objetivo de "elaborar proposta de alteração do Sistema de Gestão de Documentos Correntes (GDC) para numerar, controlar, tramitar e arquivar processos e de cronograma para implantação das alterações". Este grupo, após analisar as soluções de mercado e de outros órgãos públicos, como o Ministério da Marinha, a CGU e a Receita Federal, apresentou a proposta de adesão à Portaria SLTI/MPOG nº 3/2003, de 6/05. Esta portaria orienta os órgãos da Presidência da República, ministérios, autarquias e fundações integrantes do Sistema de Serviços Gerais - SISG quanto aos procedimentos relativos às atividades de Comunicações Administrativas. A referida portaria, no art. $7^{\circ}$, expressa a possibilidade de adesão das empresas estatais: “As Empresas Públicas poderão adotar a sistemática de numeração única de processo, mediante solicitação de cadastramento no Ministério ao qual estão vinculadas". A proposta foi aprovada na reunião da Diretoria Executiva (REDIR) de 15 de agosto de 2011 (Anexo II). Com essa decisão organizacional, a ECT passou a utilizar o número único de protocolo, o NUP, e uma nova cultura estava nascendo.

\subsection{A Nova Sistemática de Gestão Documental a partir de 2011}

Decorrente da decisão de adotar o NUP, foi instituído um novo grupo de trabalho, através da PRT/VIPAD nº13/2011, de 9 de setembro, específico para tratar da Cláusula 2a ${ }^{\mathrm{a}} \mathrm{O}$ GT tinha como objetivo "instituir os procedimentos para autuar, numerar, controlar, tramitar e arquivar processos". A Portaria teve como referência os seguintes normativos: 1) Lei nº 9.784, de 29 de janeiro de 1999, 2) Lei $\mathrm{n}^{\mathrm{o}}$. 8.159, de 8 de janeiro de 1991,3) Portaria Normativa $\mathrm{n}^{\mathrm{o}}$. 3 , de 16 de maio de 2003, 4) Termo de Ajustamento de Conduta - Inquérito Civil nº. 1.16.000.000919/2005-09. Os dois GTs, sob a coordenação desta autora, foram responsáveis 
pelas alterações no Sistema de Gestão de Documentos Correntes - GDC, para que fosse possível autuar e acompanhar a tramitação de processos e demais documentos, assim como, emitir o NUP - Número Único de Processo.

Através de Comunicação Interna Circular (CI/PRESI nº 0325/2011- Circular), no dia 3 de outubro de 2011, o Presidente dos Correios, Wagner Pinheiro de Oliveira, informa a todos os empregados que a partir daquela data uma nova sistemática de gestão documental e de formação de processos administrativos estaria sendo implantada na ECT. O registro de protocolo de processos e a garantia de uma correta instrução e tramitação, com a adoção do NUP - Número Único de Protocolo, seria implantado em toda a empresa, de norte a sul do país.

Figura 5 - Nova Sistemática (a partir de 2011)

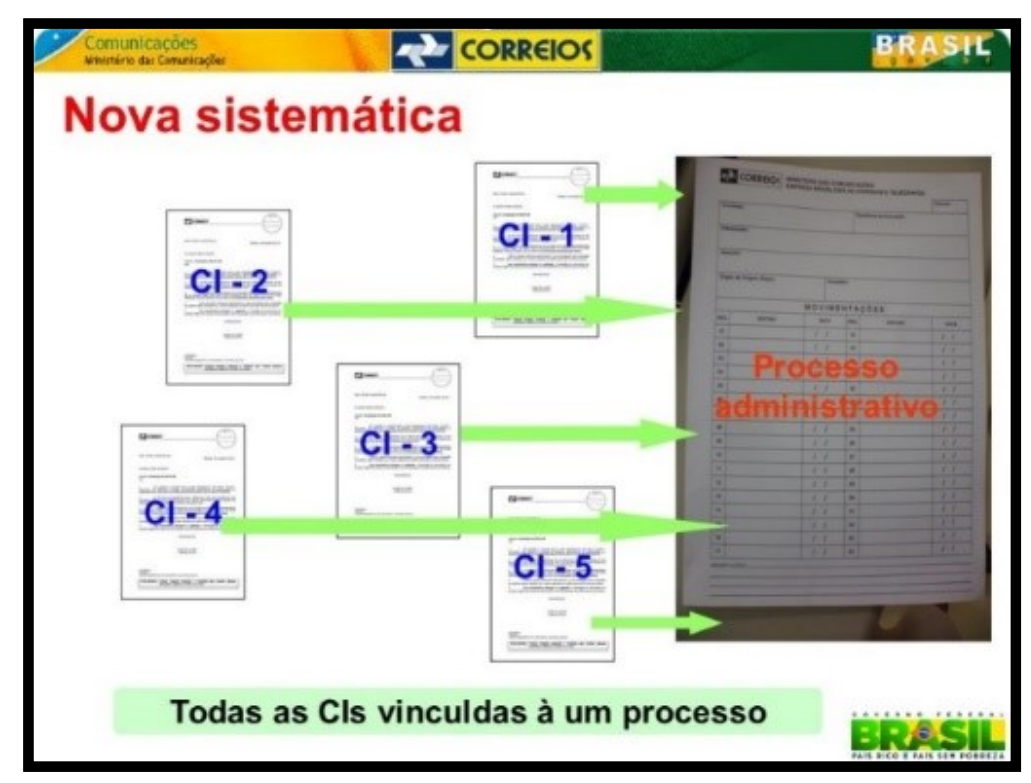

Fonte: elaborado pela autora

No processo de sensibilização dos empregados da empresa, para adoção da nova sistemática de gestão documental, foi apresentada como justificativa a necessidade de transparência, de publicidade dos atos administrativos, da defesa da probidade administrativa, do controle de toda a tramitação dos documentos, de recuperação da informação, sobretudo, da segurança para quem trabalha corretamente. Para dar suporte a esta ação foram autorizadas três vagas de Arquivistas no Concurso Público de 2011, e durante a vigência do edital foram realocadas mais vagas, aumentando o corpo técnico, assim como a alocação de concursados da 
área de Administração para compor a equipe. A Vice-Presidência de Administração (VIPAD) $)^{59}$ passou por reestruturação e em fevereiro de 2012, ao criar o Departamento de Gestão de Cadeia de Suprimento e Serviços Gerais (DEGSS), criou a Gerência Corporativa de Processos de Gestão Documental (GDOC) que passou a ser a responsável pela implantação do NUP e GDC e pela formulação e concepção da Política de Gestão Documental da ECT.

Outra ação, derivada do TAC foi a criação do Núcleo de Documentação e Arquivo (NDA), na Gerência de Gestão Documental (GDOC) vinculado à Central de Serviços (CEREL), responsável pela execução da política de gestão documental. Em função das grandes massas documentais que envolvem muitas licitações, definiu-se por uma política de digitalização dos processos de contratação e das fichas financeiras dos empregados. A empresa contratada para este serviço utiliza o procedimento de digitalizar em formato de imagem, e o processo, ainda na fase corrente, fica no NDA. O processo fica disponível ao gestor da área que pode acessá-lo pelo sistema. Os documentos a serem inseridos no processo, são encaminhados ao NDA que digitaliza e os insere, obedecendo às normas processuais, dentro do processo físico.

Figura 6 - Organograma Parcial da VIPAD (março/2012 a julho/2015)

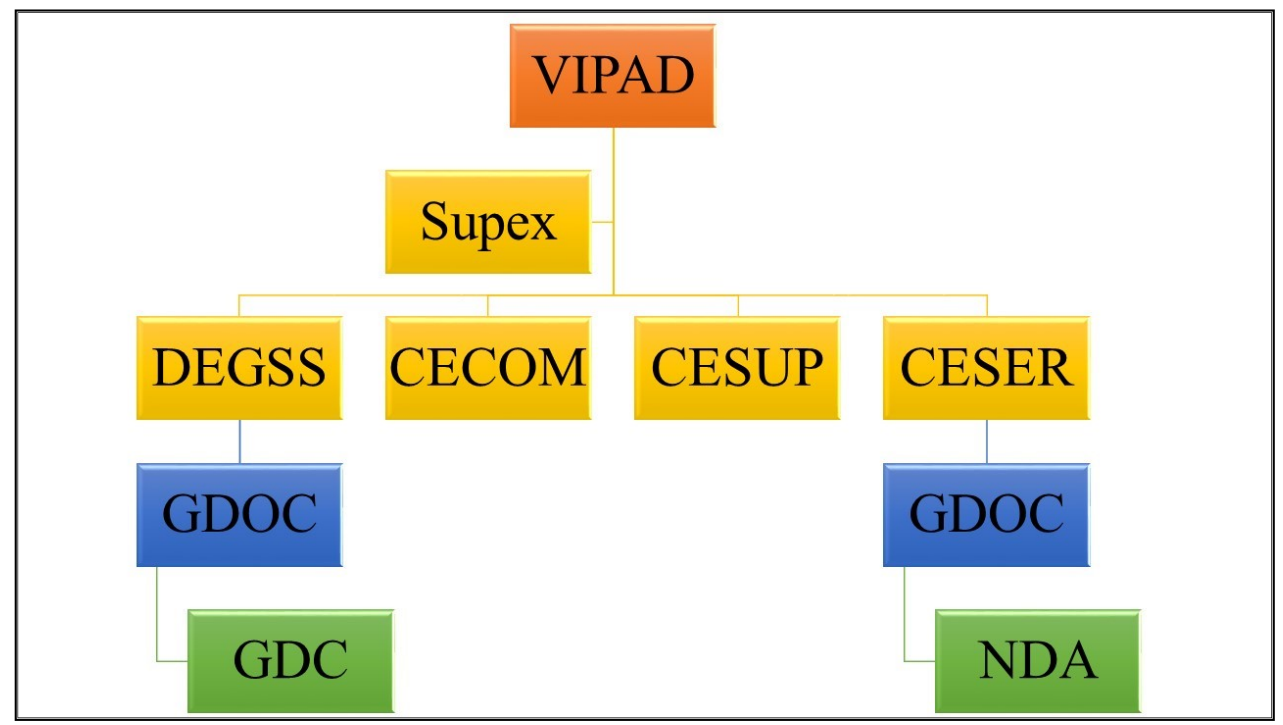

Fonte: elaborado pela autora ${ }^{60}$

${ }^{59}$ Em julho de 2015, a ECT passou por nova reestruturação e extinta a VIPAD. A maior parte de seus Departamentos passou para a Vice-Presidência de Serviços (VISER), mas o DEGSS foi para a Vice-Presidência Corporativa (VICOR), onde se concentra a área de Tecnologia e Infraestrutura. A estrutura organizacional da ECT está disponível na página na internet $<$ http://www.correios.com.br/sobre-correios/a-empresa/quemsomos/estrutura-organizacional $>$ até o $3^{\circ}$ nível hierárquico, não sendo disponibilizado os demais níveis.

${ }^{60}$ A VIPAD, Vice-Presidência de Administração, manteve a Supex - Superintendência Executiva, e passou a ter 1 departamento (DEGSS - Departamento de Gestão de Cadeia de Suprimento e Serviços e 3 centrais (CECOM Central de Compras; CESUP - Central de Suprimentos; CESER - Central de Serviços Gerais). GDOC são 
No Quadro 5 podemos identificar o diagnóstico e as soluções encaminhadas na empresa relativas à gestão documental.

Quadro 5 - Diagnóstico e Soluções na Gestão Documental /ECT

\begin{tabular}{|c|c|c|}
\hline Condições até 2011 & Cons equências & Solução \\
\hline $\begin{array}{l}\text { Inexistência de padrão de } \\
\text { procedimentos de gestão documental }\end{array}$ & $\begin{array}{l}\text { Dispersão dos documentos } \\
\text { produzidos - tramitavam de } \\
\text { forma avulsa }\end{array}$ & $\begin{array}{l}\text { Estruturação da informação } \\
\text { em forma de Processo } \\
\text { Administrativo em toda ECT }\end{array}$ \\
\hline $\begin{array}{l}\text { Tratamento simultâneo do mesmo } \\
\text { assunto em vários órgãos }\end{array}$ & $\begin{array}{l}\text { Insegurança na tomada de } \\
\text { decisões }\end{array}$ & Implantação do NUP \\
\hline $\begin{array}{l}\text { Falta de controle sistematizados dos } \\
\text { documentos produzidos }\end{array}$ & $\begin{array}{l}\text { Dificuldade no acesso à } \\
\text { informação e de sua } \\
\text { recuperação }\end{array}$ & $\begin{array}{l}\text { Definição do GDC (Gestão de } \\
\text { Documentos Correntes) como } \\
\text { sistema corporativo }\end{array}$ \\
\hline
\end{tabular}

Fonte: Elaborado pela autora

Esta iniciativa fomentou o processo de mudança na cultural organizacional e o aprimoramento da gestão documental de maneira mais ampla, proporcionando condições favoráveis de transparência, segurança, controle e, consequentemente, maior eficácia da gestão, além do alinhamento dessa ação com os princípios constitucionais da legalidade, publicidade e eficiência (LEONEL; CRUZ, 2015, p.7).

O Código de Classificação de Documentos de Arquivo para a Administração Pública: Atividades-Meio, de acordo com a Resolução $n^{0} 14$ do Conselho Nacional de Arquivos (CONARQ), foi inserida no GDC orientando assim o processo de arquivamento dos documentos/processos, de acordo com a tabela de temporalidade. A capacitação para a nova sistemática de gestão documental envolveu milhares de empregados, tanto com turmas presenciais, como material em $\mathrm{EaD}$ (educação a distância) produzido com apoio da Universidade Corporativa dos Correios (UNICORREIOS) e o Departamento de Relacionamento Institucional (DERIN). Além disso foi elaborado e confeccionado um Guia de Procedimentos e o Manual de Gestão Documental com a novas orientações relativas à gestão documental na empresa.

Gerencias de Documentação, uma formula (DEGSS) e outra executa (CESER). O GDC é um sistema de Gestão de Documentos Correntes e o NDA, o Núcleo de Documentação e Arquivo que não compõem a estrutura administrativa. 
O cronograma de implantação da nova sistemática na Administração Central (AC) foi cumprido integralmente, concluindo a implantação na Auditoria e Presidência no dia 9 de dezembro de 2011.

Quadro 6 - Cronograma de implantação da nova sistemática na AC (2011)

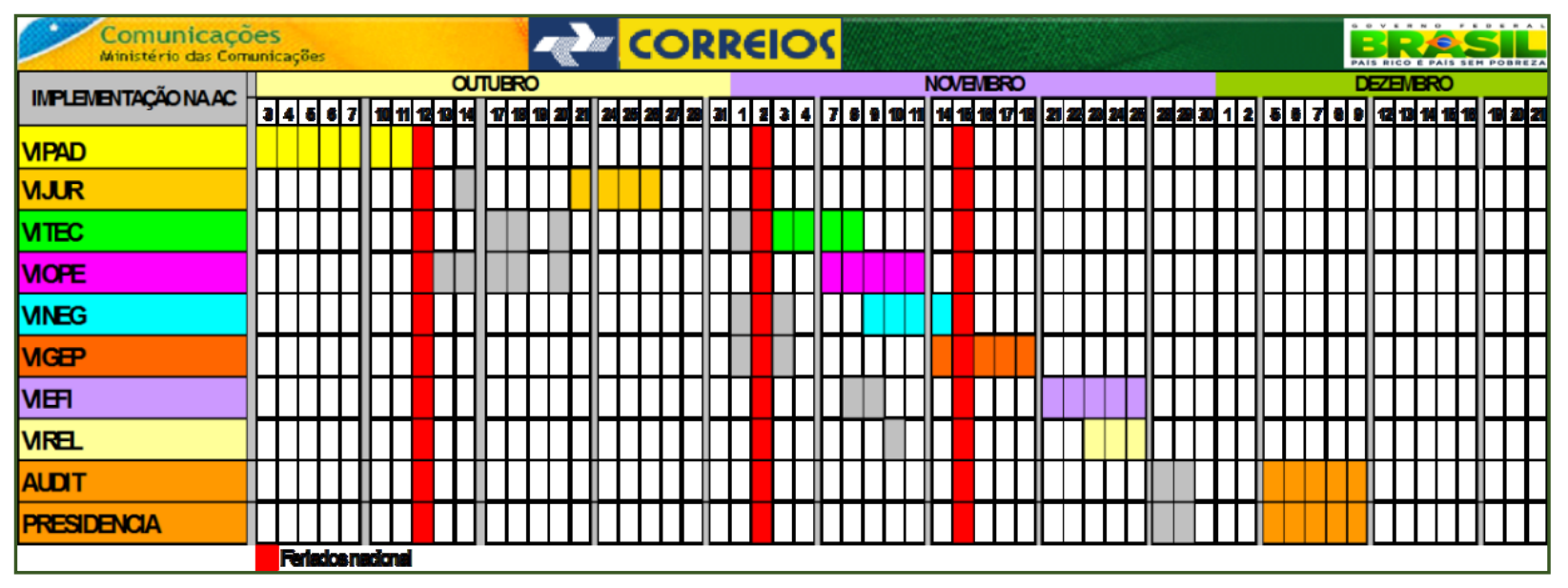

Fonte: Grupo de Trabalho PRT/VIPAD 13/2011

A nova sistemática de gestão documental na ECT veio favorecer o controle, a legalidade dos atos administrativos, a possibilidade de rastreabilidade e a garantia de transparência. Além desses fatores, ela favorece a eficácia da gestão pública ao possibilitar maior segurança para os atos da organização e do empregado, no exercício das suas funções. Estas premissas foram consideradas bases concretas na consolidação da ECT em se afirmar como Empresa de classe Mundial, uma meta presente no Plano Estratégico ${ }^{61}$ da empresa para o ano 2020.

O passo seguinte foi a elaboração do plano de classificação das atividades-fim e a tabela de temporalidade. Após o processo de implantação da nova sistemática em todo o Brasil, que se concluiu em 2014, a GDOC/DEGSS conduziu as negociações com o Arquivo Nacional para a conclusão desse passo fundamental.

A concretização desta política, traçada em 2011, foi tornada pública através da Portaria $\mathrm{n}^{\mathrm{o}} 258 / 2016^{62}$, de 13 de outubro, pela qual o Diretor-Geral do Arquivo Nacional aprova, pelo

\footnotetext{
${ }^{61}$ Plano Estratégico 2020 - plano aprovado no Conselho de Administração em que determina a meta de tornar a ECT um conglomerado empresarial moderno, flexível, dinâmico e com negócios diversificados, ajustado ao nível de desenvolvimento do País até 2020 (divulgado publicamente no dia 14.dez.2011, disponível em http://blog.correios.com.br/correios/?p=1359)

62 Portaria $n^{\circ}$ 258/2016, de 13 de outubro, publicada no Diário Oficial da União n ${ }^{\circ} 200$, de 18 de outubro de 2016, Seção I, p. 19.
} 
prazo de 24 (vinte e quatro) meses, o Código de Classificação e a Tabela de Temporalidade e Destinação dos Documentos de Arquivo relativos às atividades-fim da ECT. Nesse prazo a empresa deveria elaborar relatório circunstanciado apresentando uma análise do impacto da utilização dos instrumentos de gestão de documentos no órgão, apontando as necessidades de alteração e/ou complementação. Também deveria elaborar Listagem de Eliminação de Documentos resultante da aplicação do Código de Classificação e da Tabela de Temporalidade e Destinação de Documentos de Arquivo relativos às atividades-fim, que seria aprovada pela Comissão Nacional Permanente de Avaliação de Documentos (CPAD) e pela autoridade competente da ECT, e encaminhada ao Arquivo Nacional para que seja autorizada a eliminação dos documentos, conforme legislação em vigor. Após cumprir essas etapas poderia receber, por parte do Arquivo Nacional, a aprovação por prazo indeterminado destes instrumentos de gestão de documentos.

Em dezembro de 2015, a ECT assinou o termo de Cooperação Técnica com o MPOG para adesão ao Sistema Eletrônico de Informações (SEI) ${ }^{63}$, e definiu quatro projetos piloto, os quais foram implantados até maio de 2016. A adoção do SEI em toda a empresa será um passo importante para a transparência das informações e facilidade em conceder o acesso às informações neles contidas.

A nova sistemática de gestão documental encontrou algumas resistências, principalmente na área operacional e de logística da empresa, ou seja, nas áreas voltadas ao ambiente empresarial. As críticas são a de que estar-se-ia implantando uma gestão burocrática, trazendo lentidão à tomada de decisão. Entretanto, a firme posição política da administração superior da empresa em 2011 foi decisiva para a concretização das mudanças. A Diretoria Executiva decidiu que somente seriam analisados e deliberados, nas reuniões de Diretoria Executiva, os processos que viessem corretamente autuados e instruídos. As áreas de administração e, posteriormente, a de gestão de pessoas estimularam esta mudança de cultural organizacional e de gestão. A ECT começou assim, a sua preparação para a nova era da transparência, a nova era de que as informações são públicas e o sigilo é a exceção.

Portanto, todo o esforço esteve voltado para organizar os procedimentos que envolvem a produção, tratamento técnico e preservação dos acervos arquivísticos e informacionais de

${ }^{63}$ O Sistema Eletrônico de Informações (SEI!), desenvolvido pelo Tribunal Regional Federal da $4^{\text {a }}$ Região (TRF4), é uma plataforma que engloba um conjunto de módulos e funcionalidades que promovem a eficiência administrativa. A adesão dos Correios foi assinada em 22.dez.2015, notícia publicada no Blog dos Correios. 
modo a possibilitar a sua recuperação para atender às demandas, não apenas dos órgãos de controle, mas principalmente da sociedade.

A ECT possui ainda um museu, o Museu dos Correios, como descrito na página na internet, "tornou-se referência em conservação, pesquisa e exibição de objetos relativos à História Postal e Telegráfica do Brasil, com ênfase especial para a Filatelia nacional e internacional". Oliveira (2010, p.14) destaca que apesar da constante afirmação dos arquivos como parte da memória de uma coletividade, a concepção de memória utilizada raramente se expressa no conhecimento arquivístico sistematizado. Uma estrutura na empresa mais voltada a área de filatelia e cultural, não havendo um local, como um centro de memória, em que as ações enquanto órgão público, estivessem disponíveis para acesso público, assim como, buscando resgatar as informações tangíveis para registro e conhecimento público.

É necessário a definição de uma rotina, com procedimentos e fluxos estabelecidos na organização para a identificação dos documentos que devam ser preservados, esta não deve ser uma tarefa de decisão individual do gestor. Com a aprovação da classificação das atividadesfim e da tabela de temporalidade da ECT, e utilização de sistema integrado, poderá ser possível a construção de normas que avancem na constituição da memória institucional.

Por fim, os Correios possuem Arquivos Gerais, que recebem os documentos das diversas áreas da empresa no respectivo estado e é armazenado o arquivo permanente da empresa. Na sede em Brasília, e nas Diretorias Regionais, toneladas de arquivos estão aguardando a análise para eliminação suspensa pela não existência de um Plano de Classificação da atividade-fim, e consequente definição de temporalidade. As cláusulas $3^{\mathrm{a}}$ e $4^{\mathrm{a}}$ do TAC determinaram a guarda em local com acesso controlado, pelo prazo de 10 (dez) anos, contados da assinatura deste Termo, mantendo a integridade dos processos. Assim como, não expurgar quaisquer documentos relacionados aos processos de contratação sob investigação do MPF, TCU, CGU e PF ou que estivessem sub judice. Em 2014, cerca de 60 toneladas de diversos tipos de papéis foram doadas pelos Correios à Cooperativa Ecologicamente Correta de Materiais Recicláveis de Bauru (Coopeco). A doação é uma das opções de eliminação e envolviam documentos dos anos de 2006 e 2007 pertencentes ao arquivo geral da diretoria regional sediada em Bauru, interior de São Paulo. O descarte recebeu a devida aprovação do CONARQ e da Administração Central dos Correios. Em 2015, foram autorizadas a eliminação 
de 115.793 caixas da série balancete de agências, liberando espaço equivalente a $16,21 \mathrm{~km}$ lineares ou 3.216 estantes nos Arquivos Gerais das Diretorias Regionais ${ }^{64}$.

${ }^{64}$ Estas notícias foram amplamente divulgadas na empresa, constituindo um marco importante na gestão documental da ECT e avanços quanto a organização dos Arquivos Gerais. Sustentabilidade em 2014, DR São Paulo Interior <file:///C:/Users/A/Downloads/Relatorio_Gestao_Exercicio_2014.pdf $>$ e Diversas regionais $<$ http://blog.correios.com.br/correios/?p=14712>. 


\section{A IMPLANTAÇÃO DA LAI NA ECT}

[...] Adieu, cartas baratas! Diligências e carteiros, adieu;

Sua função se acabou, seu emprego se perdeu:

Telégrafos em nossas casas teremos no seu lugar

servindo como relógios, para-raios, varais e para notícias enviar"

Charles Dibdin ${ }^{65}$

\subsection{O Monitoramento}

No seu art. 47, a Lei de Acesso à Informação, estabelece o prazo de 180 (cento e oitenta) dias para sua entrada em vigor. A LAI tinha data certa para entrar em vigor: dia 16 de maio de 2012.

O art. 41, atribuiu ao Poder Executivo a responsabilidade de designar o órgão da administração pública federal responsável pela campanha de abrangência nacional de fomento à cultura da transparência na administração pública e à conscientização do direito fundamental de acesso à informação; pelo treinamento de agentes públicos; pelo monitoramento da aplicação da lei no âmbito federal e pelo encaminhamento do relatório anual ao Congresso Nacional. Através do Decreto $\mathrm{n}^{\mathrm{o}} 7.724 / 2012$, em seu artigo 68, o Poder Executivo designou a Controladoria Geral da União para esta atribuição.

Jardim (2012, p.15) destaca o fato de a CGU, criada em 2001, ser um órgão inserido na estrutura da Presidência da República, com suas competências definidas em 2003 pela Lei ${ }^{\circ}$ 10.683, receber as funções de monitoramento da LAI, sem ter competências e servidores especializados na gestão da informação, como ocorre em agências de informação especializadas. Outro aspecto é a necessária independência para decidir sobre os recursos decorrentes de pedidos de informação, como destacado por organizações como a Artigo 19 e autores como Mendel (2011, p.47), que ressalta que sem uma revisão independente, muitas informações nunca serão divulgadas.

\footnotetext{
${ }^{65}$ Animador e compositor da Drury Lane em Londres, incluiu o invento do Telégrafo em espetáculo musical em 1794, prevendo um futuro maravilhoso (GLEICK, 2013, p.143)
} 
No México, a Lei Federal de Transparência e Acesso à Informação Pública, aprovada em 2002, incluiu um órgão de supervisão independente, o Instituto Federal de Acesso à Informação (IFAI) ${ }^{66}$ responsável pelas regras de classificação e pelos recursos (SÁ; MALIN, 2012, p.10).

Nos primeiros quatro anos da LAI, a CGU esteve vinculada à Presidência da República. A partir de 12 de maio de 2016, a CGU foi extinta pela Medida Provisória $\mathrm{n}^{\mathrm{o}} 726$, convertida em Lei $\mathrm{n}^{\mathrm{o}}$ 13.341, em 29 de setembro de 2016, e criado o Ministério da Transparência, Fiscalização e Controle. De acordo com o Art. 19 da referida lei, apenas após a edição do decreto de estrutura regimental do novo órgão é que produz os efeitos da lei, que se efetivou em 22 de novembro de 2016, com a publicação do Decreto $n^{0} 8.910 / 2016^{67}$. O que só reforça a importância de um órgão específico e com autonomia para o monitoramento da LAI.

Nesta seção apresentaremos a atuação da CGU, do Departamento de Coordenação e Governança das Empresas Estatais (DEST), vinculado ao Ministério do Planejamento (MP), e do Ministério das Comunicações (MC) no monitoramento e acompanhamento da implantação da LAI na ECT em 2012, e o quanto foi importante e imprescindível para que a mesma fosse concretizada na empresa.

Monitoramento da CGU

A CGU, a partir de fevereiro de 2012, através de ofícios enviados diretamente ao presidente da empresa, determinou o passo-a-passo a ser seguido para garantir que toda a administração pública cumprisse fielmente a lei. O comprometimento da alta direção dos órgãos era elemento prioritário na ação. A ECT organizou várias reuniões internas e foi um dos patrocinadores da $1^{\text {a }}$ Conferência Nacional sobre Transparência e Controle Social CONSOCIAL $^{68}$ em que reafirmou seu alinhamento com a política de tornar a informação uma

\footnotetext{
${ }^{66}$ Em maio de 2015 o IFAI se transformou no Instituto Nacional de Transparência, Acesso a Informação e Proteção de Dados Pessoais. <http://expansion.mx/nacional/2015/05/06/el-ifai-cambia-de-nombre-a-inai-trasaprobacion-de-ley-de-transparencia $>$

${ }^{67}$ Decreto $^{\circ}$ 8.910/2016, disponível em < http://www.planalto.gov.br/ccivil_03/_ato20152018/2016/Decreto/D8910.htm>

${ }^{68}$ O evento realizou-se de 18 a 20/05/2012 em Brasília, disponível em

$<$ http://blog.correios.com.br/correios/?p=2622>
} 
regra e o sigilo uma exceção, e instalou um estande do SIC - Serviço de Informações ao Cidadão na feira de evento.

No processo de implantação da LAI a CGU apresentou um cronograma a ser seguido, reproduzido abaixo.

Quadro 7 - Cronograma de Implantação da LAI - CGU

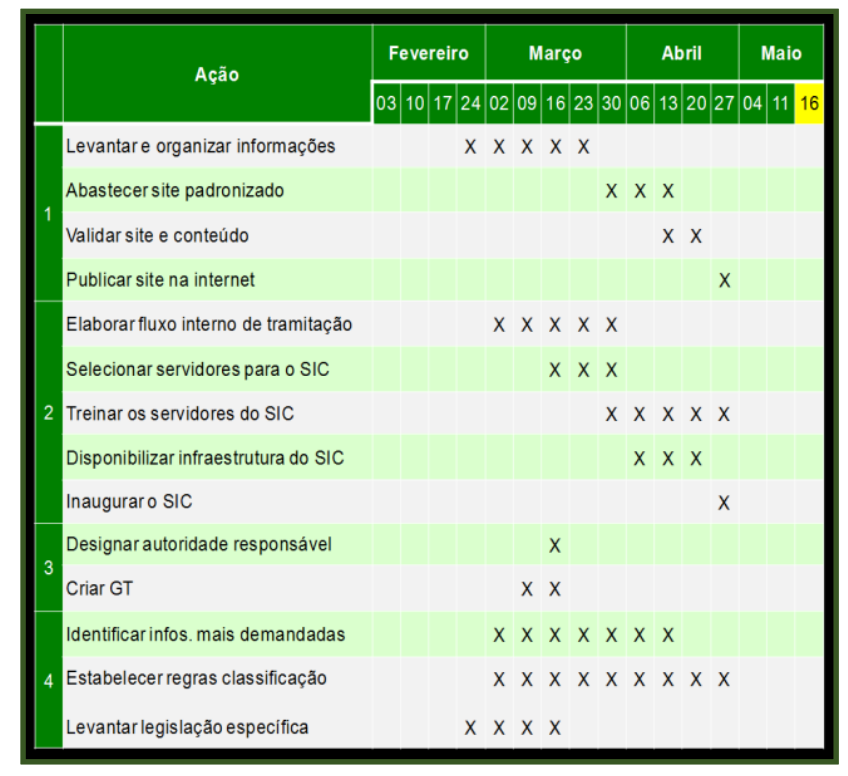

Fonte: $\mathrm{CGU}^{69}$

O Presidente da ECT instituiu, então, o Grupo de Trabalho (GT $)^{70}$ com representantes de todas as áreas da empresa, incumbido de cumprir cada etapa determinada na planilha de execução enviada pelo órgão de controle. O checklist envolvia desde o levantamento e organização das informações, e desenvolvimento da página de acesso à informação na internet, às regras para classificação de informação. Através de despacho do Presidente da ECT, foi designado o Chefe da Ouvidoria, Sr. Lucio da Silva Santos para exercer a função de Autoridade de Monitoramento da $\mathrm{LAI}^{71}$ e esta autora como sua suplente.

No processo de implantação da LAI, a CGU encaminhou um Guia em que identificava as informações obrigatórias na página na internet, que cada órgão deveria disponibilizar

\footnotetext{
${ }^{69}$ Imagem extraída da planilha elaborada pela CGU, de controle de implantação da LAI, enviada aos órgãos.

${ }^{70}$ GT implantação da LAI iniciou suas atividades em fevereiro, mas não havia sido publicado no Diário Oficial da União, assim, nova portaria foi emitida e então publicada. Portaria $n^{\circ} 32$, de 24 de abril de 2012. Publicada no D.O.U no 82, de 27/04/2012, Seção 2, p.40

${ }^{71}$ Designação da Autoridade de Monitoramento da LAI na ECT, publicado no D.O.U no 87, de 7/05/2012, Seção 2, p.45.
} 
(Quadro 8). O checklist deveria ser atualizado a cada semana informando o andamento: Não se aplica; Não iniciado, Iniciado, Avançado e Concluído.

Quadro 8 - Controle de Informações na Página Acesso à Informação

\begin{tabular}{|l|l|l|}
\hline \multicolumn{2}{|c|}{$\begin{array}{l}\text { As respostas dos itens abaixo } \\
\text { deverão variar entre: }\end{array}$} & $\begin{array}{l}\text { - Não se aplica } \\
\text { - Não Iniciado } \\
\text { - Iniciado } \\
\text { - Avançado } \\
\text { - Concluído }\end{array}$ \\
\hline \multicolumn{1}{|c|}{ Status do levantamento das informações dos itens do Guia } & Não Iniciado & \multicolumn{1}{c|}{ COMENTÁRIO/DÚVIDAS } \\
\hline 1- Institucional & Não Iniciado & \\
\hline 2- Ações e programas & Não Iniciado & \\
\hline 3- Auditorias & Não Iniciado & \\
\hline 4- Convênios & Não Iniciado & \\
\hline 5- Despesas & Não Iniciado & \\
\hline 6- Licitações e Contratos & Não Iniciado & \\
\hline 7- Servidores / Empregados & Não Iniciado & \\
\hline 8- Perguntas Frequentes & Não Iniciado & \\
\hline 9- Serviço de Informações ao Cidadão - SIC & \\
\hline
\end{tabular}

Fonte: $\mathrm{CGU}^{72}$

A ECT realizou, no dia 27 de março de 2012, uma reunião com a presença da alta direção da Empresa - Presidente, Vice-Presidentes e Superintendentes Executivos, Assessores e o Grupo de Trabalho (informação pessoal) ${ }^{73}$. Na ocasião a Dra. Vânia Vieira, então Diretora de Prevenção da Corrupção da CGU fez uma palestra sobre a importância da Lei de Acesso à Informação e tirou dúvidas dos gestores. A atividade foi filmada e disponibilizada a todos os empregados da empresa, no processo de sensibilização e motivação para a adesão à LAI. No dia 15 de maio, o SIC-ECT foi inaugurado pelo Presidente da empresa com grande destaque nos meios de comunicação da empresa e nacional (BRASIL/Presidência, 2011a).

O envolvimento da direção da ECT e o acompanhamento sistemático da CGU foram fundamentais para a implantação da LAI na empresa. Como analisado anteriormente, não havia (e ainda não há) a cultura na empresa de internalização da legislação que se aplica ao conjunto da administração pública federal. Conforme analisamos nos relatórios do MPF e na CPMI, os manuais encontravam-se desatualizados quanto à legislação vigente. Algumas vezes a atualização dava-se em função de auditorias do TCU, ligadas às prestações de contas anuais.

\footnotetext{
72 Idem 69

${ }^{73}$ Esta autora participou da organização e da reunião.
} 
Mesmo com todas as mudanças registradas, a importância do monitoramento para a implantação de legislações dessa amplitude, se faz necessária. Um exemplo, vivido por esta autora, diz respeito à Lei de Conflito de Interesse, promulgada em 2013 e, como gestora do SIC, enviamos memorandos aos órgãos envolvidos, quanto à necessidade de ampla divulgação e efetivação dos mecanismos previstos na lei, como a agenda pública na internet dos gestores até o $5^{\circ}$ nível de poder e mecanismo de notificação quanto aos possíveis conflitos de interesse dos seus empregados com a ECT. Apenas em 2015, a área de gestão de pessoas emitiu uma orientação sobre a questão de exercício de atividades fora da empresa e, até dezembro de 2016, apenas a agenda do Presidente está disponível em transparência pública.

Monitoramento do DEST/MPOG

O empenho do governo Dilma Rousseff na implantação da LAI, no âmbito do executivo da administração pública federal, foi bem intenso. No dia 6 de março de 2012, em reunião envolvendo a Casa Civil da Presidência da República e a CGU, o DEST recebeu a incumbência de acompanhar a implementação em cada estatal (Anexo IV). Por meio de relatório enviado semanalmente, cada uma das etapas previstas no cronograma, era monitorada. O DEST, através do seu então Diretor Murilo Barella, e da Coordenação de Avaliação de Empresas, deveria resolver as dúvidas operacionais e colher as sugestões referentes à regulamentação da LAI para as estatais. O Monitoramento específico começou no dia 15 de março de 2012 e se encerrou dia 16 de maio do mesmo ano.

O objetivo do monitoramento era garantir que todas as empresas estivessem preparadas para entrada em vigência da lei, entendendo que era mais fácil identificar riscos e saná-los a tempo, encontrar os pontos críticos, e resolvê-los e ajudar a nortear as atividades que precisavam ser realizadas. O governo alertava a todo momento de que não se tratava de uma nova ferramenta de controle e sim uma nova forma de relacionamento com a sociedade.

Cada estatal recebeu por email a planilha do DEST para ser atualizada. Na semana do dia 2 de maio de 2012, faltando 14 dias para o início da lei, o quadro nas Estatais não era positivo, a maioria estava fora dos prazos estabelecidos. A ECT também enfrentava dificuldades. 
Na Tabela 3 verifica-se o estágio de cumprimento de cada uma das ações definidas pelas 114 empresas estatais federais ${ }^{74}$ sob monitoramento do DEST. Na Tabela 4 consta o controle na elaboração da página da LAI do órgão, ou seja, a disponibilização em Transparência Ativa das informações obrigatórias. Cada linha das tabelas 3 e 4 identifica um item e as setas indicam o percentual de evolução. Quando a situação "Não iniciado" estivesse zerada, significava que $100 \%$ já estava envolvido na tarefa.

A maioria das empresas estatais enfrentaram dificuldades. De acordo com a Tabela 3 a inauguração do SIC, a publicação da página na internet, sua validação e conteúdo, e o treinamento dos servidores foram os que mais apresentaram problemas. Na Tabela 4, verificamos que a disponibilização de Ações e Programas e as informações sobre o SIC foram as que mais demoraram a serem disponibilizadas.

Tabela 3 - Controle das Ações - DEST/MPOG, em 2/05/2012

\begin{tabular}{|c|c|c|c|c|c|c|}
\hline Cód. & Ação & Prazo & Não Inicia do & Iniciado & Ava nça do & Concl uído \\
\hline & Levantar e organizar informa ções & $23 / \mathrm{mar}$ & $0 \%$ & $16 \%$ & $36 \%$ & $43 \%$ \\
\hline & Abastecer site padronizado & $13 / a b r$ & $0 \%$ & $11 \%$ & $57 \%$ & $27 \%$ \\
\hline & Validar site e conteúdo & $20 / a b r$ & $16 \%$ & $25 \%$ & $32 \%$ & $23 \%$ \\
\hline 1.d & Publicarsite na internet & $27 / a b r$ & $27 \%$ & $20 \%$ & $27 \%$ & $20 \%$ \\
\hline 2.a & Elaborar fluxo interno de tramitação & $30 / \mathrm{mar}$ & $5 \%$ & $16 \%$ & $30 \%$ & $45 \%$ \\
\hline 2.b & Selecionar servidores para o SIC & $30 / \mathrm{mar}$ & $7 \%$ & $14 \%$ & $16 \%$ & $59 \%$ \\
\hline $2.2 . c$ & Treinar os servidores do SIC & $27 / a b r$ & $14 \%$ & $23 \%$ & $20 \%$ & $39 \%$ \\
\hline 2.d & Disponibilizar infra estrutura do SIC & $20 / a b r$ & $7 \%$ & $25 \%$ & $32 \%$ & $32 \%$ \\
\hline 2.e & Inaugurar SIC & $27 / \mathrm{abr}$ & $41 \%$ & $11 \%$ & $30 \%$ & $11 \%$ \\
\hline 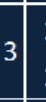 & Designarautoridade responsável & $16 / \mathrm{mar}$ & $5 \%$ & $0 \%$ & $20 \%$ & $70 \%$ \\
\hline 3.b & Criar GT & $16 / \mathrm{mar}$ & $2 \%$ & & $16 \%$ & $75 \%$ \\
\hline \multirow{3}{*}{ 4.b } & Identificar infos mais demandadas & $13 / a b r$ & $2 \%$ & $18 \%$ & $11 \%$ & $64 \%$ \\
\hline & Esta belecer regras de classifica ção & $27 / a b r$ & $11 \%$ & $43 \%$ & $30 \%$ & $11 \%$ \\
\hline & Levantar legis lação espe cífica & $16 / \mathrm{mar}$ & $9 \%$ & $25 \%$ & $18 \%$ & $43 \%$ \\
\hline
\end{tabular}

Fonte: Apresentação do DEST/MP (Anexo IV)

${ }^{74}$ Relação das Empresas Estatais Federais, atualizada em abril de 2016 (BRASIL/MPOG, 2016) 
Tabela 4 - Controle Página da LAI - DEST/MPOG, em 2/05/2012

\begin{tabular}{|c|c|c|c|c|}
\hline & Não Inicia do & Iniciado & Avánça do & Concluído \\
\hline Ins titucional & $2 \%$ & $11 \%$ & $43 \%$ & $39 \%$ \\
\hline Ações e programas & $7 \%$ & $14 \%$ & $48 \%$ & $25 \%$ \\
\hline Auditorias & $2 \%$ & $16 \%$ & $30 \%$ & $48 \%$ \\
\hline Convênios & $5 \%$ & $16 \%$ & $20 \%$ & $41 \%$ \\
\hline Despesas & $2 \%$ & $20 \%$ & $32 \%$ & $39 \%$ \\
\hline Licitações e Contratos & $2 \%$ & $11 \%$ & $36 \%$ & $45 \%$ \\
\hline Empregados & $2 \%$ & $25 \%$ & $25 \%$ & $41 \%$ \\
\hline Perguntas Frequentes & $7 \%$ & $20 \%$ & $30 \%$ & $36 \%$ \\
\hline SIC & $7 \%$ & $36 \%$ & $20 \%$ & $32 \%$ \\
\hline
\end{tabular}

Fonte: Apresentação do DEST/MP (Anexo IV)

O processo de tramitação dos pedidos dentro do órgão era a maior preocupação. Na ECT, com a recém implantada sistemática de gestão documental, buscava-se uma forma de internalizar os pedidos de informação que a empresa receberia pelo e-SIC, com protocolo em forma de NUP. Entretanto, não era possível avançar antes do início da vigência da LAI porque o sistema era desconhecido pelos gestores (informação pessoal). A CGU disponibilizou o eSIC aos órgãos 24 horas antes da liberação ao público.

Monitoramento do Ministério das Comunicações

A ECT além do monitoramento da CGU e do DEST, também respondia ao então Ministério das Comunicações $(\mathrm{MC})^{75}$, órgão ao qual a ECT é vinculada. No âmbito do ministério foi constituído um Comitê de Monitoramento envolvendo todos os órgãos vinculados: a Agência Nacional de Telecomunicações (ANATEL), a Telecomunicações Brasileiras S.A. (TELEBRAS) e a ECT. De fevereiro de 2012 até o dia 16 de maio, foram realizadas reuniões todas as sextas-feiras para intercâmbio de dados e trocas de experiências (ANEXO V).

${ }^{75}$ Através da Medida Provisória n ${ }^{\text {o }}$ 726, de 12 de maio de 2016, convertida em Lei n ${ }^{\circ}$ 13.341, em 29 de setembro de 2016, o Ministério das Comunicações (MC) foi extinto e transformado em Ministério da Ciência, Tecnologia, Inovações e Comunicações. 
A atividade de monitoramento no ministério permitiu identificar pontos fortes como o apoio do então Ministro das Comunicações, Paulo Bernardo, e do Secretário Executivo do ministério, César Alvarez; a participação de todas as áreas meio e fim dos órgãos; o apoio da CGU e o levantamento de informações mais demandadas e, com isso, uma reorganização dos processos internos. Também apontou os pontos fracos, como o grande desconhecimento do tema entre os gestores, a resistência interna, o déficit nas áreas de recursos humanos e tecnologia da informação, o prazo exíguo, a gestão de documentos e da informação e de sistemas de informação. A grande aflição nos órgãos era a expectativa de uma grande vontade reprimida poder significar uma explosão de pedidos e como cumprir os prazos, neste possível cenário. A implantação da LAI exigia capacidade de gestão, investimento em tecnologia e compromisso político.

A página dos Correios com as informações em Transparência Ativa foi disponibilizada como determinado no cronograma, mas com limitações. No item Receitas e Despesas ${ }^{76}$ não constam as receitas da empresa. Na página da Auditoria, na qual devem constar os Processos de Contas Anuais e Resultados de Inspeções e Auditorias, as informações não são atualizadas desde 2014. Apenas em 2016, foram disponibilizadas as informações relativas às diárias e passagens dos empregados. O organograma com a estrutura da ECT, apresentada na página da LAI, se limita aos membros do Conselho de Administração, Conselho Fiscal, Presidência e Vice-Presidências e Diretores Regionais. Estatais como Banco do Brasil e Petrobrás ${ }^{77}$ apresentam a estrutura, e o nome e telefone/email dos principais dirigentes, até gerentes cumprindo o disposto na Lei de Conflito de Interesses e orientações da CGU.

\subsection{SIC ECT}

A LAI no art. $9^{\circ}$ determina que o acesso a informações pública fica assegurado mediante a criação de serviço de informação ao cidadão, que foram denominados de Serviço de Informação ao Cidadão (SIC) e da realização de audiências ou consultas públicas, incentivo à

\footnotetext{
76 Vide página na internet dos Correios no ícone da LAI.

${ }^{77}$ Vide dados Institucionais: Banco do Brasil e Petrobrás nas respectivas páginas na internet de Acesso à Informação.
} 
participação popular ou a outras formas de divulgação. Aos SICs cabe atender e orientar o público, informar sobre a tramitação de documentos e protocolizar documentos e requerimentos de acesso a informação. Portanto, não cabia aos SICs responder aos pedidos de informação e sim, aos gestores que devem assinar as respostas e, em caso de recurso, ser orientado à qual autoridade deve dirigir o seu recurso. Nesta seção estaremos apresentando citações de fontes informais (informação pessoal), fruto da participação direta da autora em cada etapa, a partir de anotações e vivência dos fatos.

O Grupo de Trabalho, instituído para implantação da LAI na ECT, aprovou a adoção de uma estrutura de tramitação dos pedidos de informação, e dos recursos, que garantisse a hierarquia preconizada pela LAI (art. 15), e estabelecida pelo Decreto $n^{0}$ 7.724/2012 (art. 21). A Figura 7 apresenta o fluxo de decisão aprovado, em que foram definidos os órgãos que respondem ao pedido inicial e os que respondem ao Recurso de $1^{\text {a }}$ Instância.

Figura 7 - Fluxo de Decisão do SIC Correios (julho/2015)

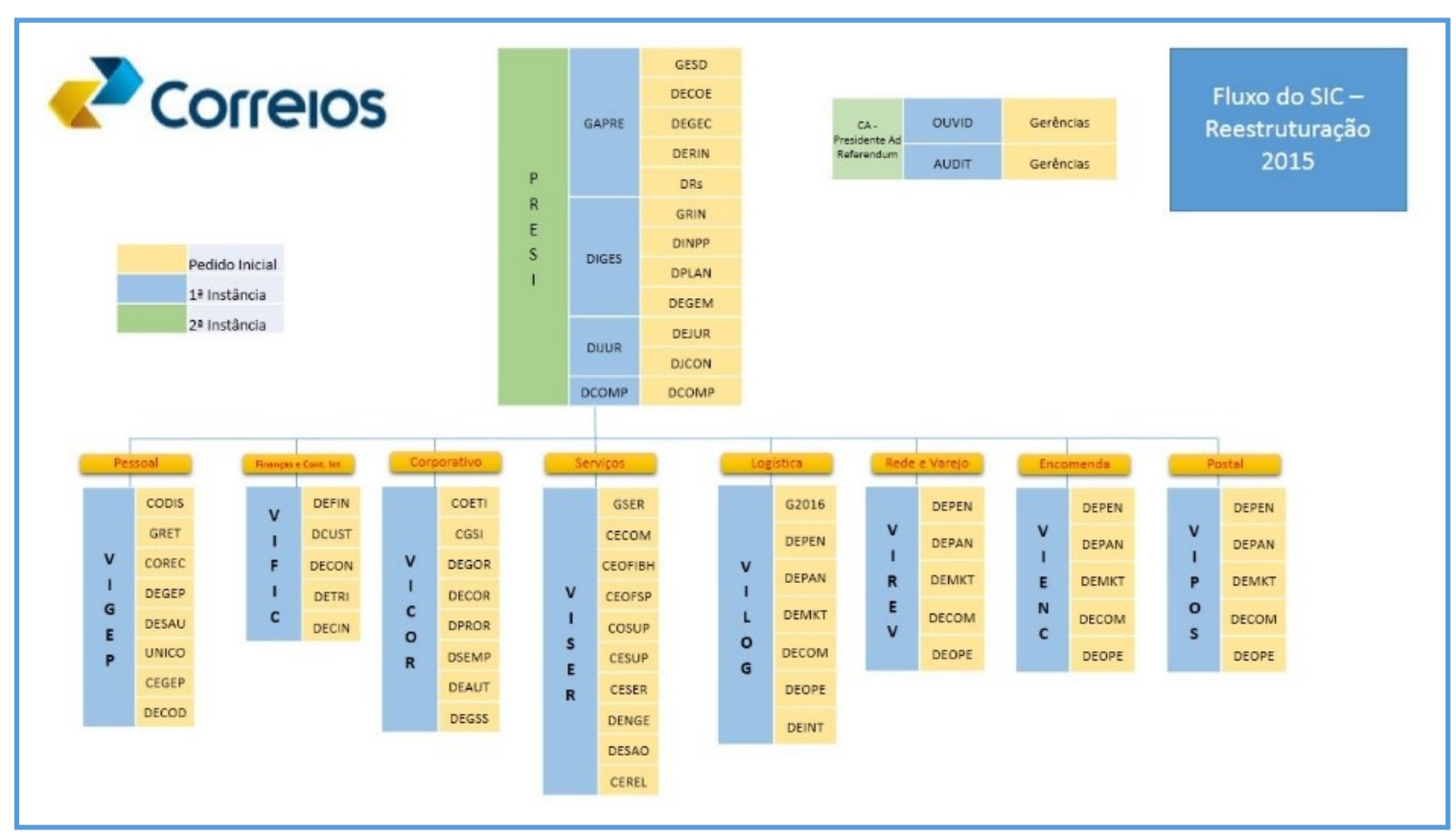

Fonte: Página de acesso à informação da $\mathrm{ECT}^{78}$

${ }^{78}$ O fluxo de decisão está disponível na página da LAI da ECT com o organograma em vigor em agosto de 2015.

$<$ http://www.correios.com.br/sobre-correios/acesso-a-informacao/servico-de-informacoes-ao-cidadao-sic $>$. 
O Recurso de $2^{\mathrm{a}}$ Instância está definido pelo Decreto $\mathrm{n}^{0} 7.724 / 2012$, como sendo a autoridade máxima do órgão, no caso, o Presidente da empresa. Portanto, o pedido inicial é respondido em primeiro nível por um chefe de Departamento ou Diretor Regional; o Recurso de $1^{\text {a }}$ Instância é respondido pelo Vice-Presidente gestor do assunto abordado, ou Chefe de Gabinete da Presidência ou Superintende Executivo (estes vinculados à Presidência). O Decreto $n^{\mathrm{o}} 7.724 / 2012$ determina ainda que os Recursos de $3^{\mathrm{a}}$ Instância são diretamente encaminhados à $\mathrm{CGU}$ e os de $4^{\mathrm{a}}$ à $\mathrm{CMRI}^{79}$.

Uma rede de representantes do Serviço de Informação ao Cidadão (SIC) foi constituída em cada Vice-Presidência, Departamento e Diretoria Regional, e da Presidência, denominados de "Pontos Focais do SIC" (PF) e com a atribuição de ser o elo de ligação do SIC-ECT com a estrutura da empresa. Os Pontos Focais são empregados, ocupantes de função de confiança, designados pelas autoridades que assinam as respostas dos pedidos de informação e recursos. Para cada órgão foi criada uma caixa postal de email pela qual as demandas, recebidas pelo sistema e-SIC, eram encaminhadas em meio eletrônico, por não existir um sistema de tramitação de documentos eletrônicos. Aos PF coube a responsabilidade de identificar dentro da sua área, o setor com gestão sobre a informação solicitada e devolver, no prazo estabelecido, ao SIC-ECT. Este procedimento permaneceu até 10 de maio de 2016, data de início de tramitação totalmente eletrônica, através do SEI.

Através de um ambiente colaborativo e de transparência dos pedidos e das respostas, desenvolvido no âmbito da intranet da empresa e com reuniões periódicas, estabeleceu-se um maior diálogo entre os PF e gestores que buscavam o aprimoramento do atendimento ao cidadão. A partir deste modelo foram desenvolvidas respostas padrões, na busca em garantir tratamento equânime da empresa para com os cidadãos, a resolução de conflitos com o uso do bom senso no atendimento às demandas recebidas. O SIC-ECT só respondia diretamente ao cidadão aos pedidos de informação sobre os serviços nacionais e internacionais comercializados pela empresa, através de resposta padrão elaborada pela área, encaminhando o cidadão ao canal especifico do "Fale com os Correios" ${ }^{"}$. Portanto, por decisão do GT todos os demais pedidos deveriam ser encaminhados diretamente aos gestores. Esta foi uma decisão importante para propiciar não só o acompanhamento dos gestores, mas para influenciar mudanças internas na organização e fluxo da informação.

\footnotetext{
${ }^{79}$ Comissão Mista de Reavaliação de Informações, criada pelo $\S 1^{\circ}$ do Art. 35 da Lei 12.527/2011

${ }^{80}$ Súmula da CMRI $n^{\circ} 1 / 2015$, regulamentou que havendo canal específico o órgão deve orientar o interessado a buscar a informação por intermédio desse canal ou procedimento. Disponível na página da CMRI na internet
} 
A capacitação dos empregados da ECT foi providenciada a partir de cursos em Educação a Distância (EaD) oferecidos pela CGU, em parceria com a Escola Nacional de Administração Pública (ENAP), amplamente divulgado na empresa. O SIC-ECT iniciou seu trabalho com um grande volume de pedidos de informação. Essa grande demanda apresentou a urgente tarefa de padronizar os procedimentos internos e desenvolver ações para enfrentar os temas mais complexos. Nos primeiros levantamentos da CGU, a ECT aparecia entre os cinco órgãos mais procurados da Administração Pública Federal, conforme Tabela 5:

Tabela 5 - Órgãos Públicos mais demandados pela LAI (2012)

\begin{tabular}{|c|c|c|}
\hline \multicolumn{3}{|c|}{$\begin{array}{l}\text { Lei de Acesso à Informação } \\
\text { Órgãos Públicos mais demandados }\end{array}$} \\
\hline Órgão & Total & $\%$ \\
\hline Superintendência de Seguros Privados (SUSEP) & 1.901 & 10,9 \\
\hline Instituto Nacional do Seguro Social (INSS) & 1.216 & 6,9 \\
\hline Banco Central do Brasil (BACEN) & 774 & 4,4 \\
\hline $\begin{array}{l}\text { Ministério do Planejamento, Orçamento e } \\
\text { Gestão (MP) }\end{array}$ & 583 & 3,3 \\
\hline Empresa Brasileira de Correios e Telégrafos (ECT) & 518 & 3,0 \\
\hline Ministério da Fazenda (MF) & 499 & 2,8 \\
\hline Caixa Econômica Federal (CEF) & 406 & 2,3 \\
\hline $\begin{array}{l}\text { Instituto Brasileiro do Meio Ambiente e dos } \\
\text { Recursos Naturais Renováveis (IBAMA) }\end{array}$ & 381 & 2,2 \\
\hline Controladoria-Geral da União (CGU) & 372 & 2,1 \\
\hline Ministério do Trabalho e Emprego (MTE) & 352 & 2,0 \\
\hline Outros & 10.514 & 60,0 \\
\hline Total & 17.516 & 100 \\
\hline
\end{tabular}

Fonte: Portal do Planalto (julho/2012) ${ }^{81}$

Os relatórios estatísticos com os pedidos de informação e recursos são de acesso público a todos os cidadãos, e estão disponíveis no sistema e-SIC (Relatórios Estatísticos). A seguir, no Gráfico 3, podemos observar que $80 \%$ dos 6.773 pedidos de informação registrados no SIC - ECT, tiveram acesso concedido.

81 Tabela publicada no Portal do Planalto, disponível em <http://www2.planalto.gov.br/acompanhe-oplanalto/caderno-destaques/julho-2012/acesso-a-informacao-e-transparencia $>$. 
Gráfico 3 - Pedidos de Informação por Tipo de Resposta ECT (2012/2015)

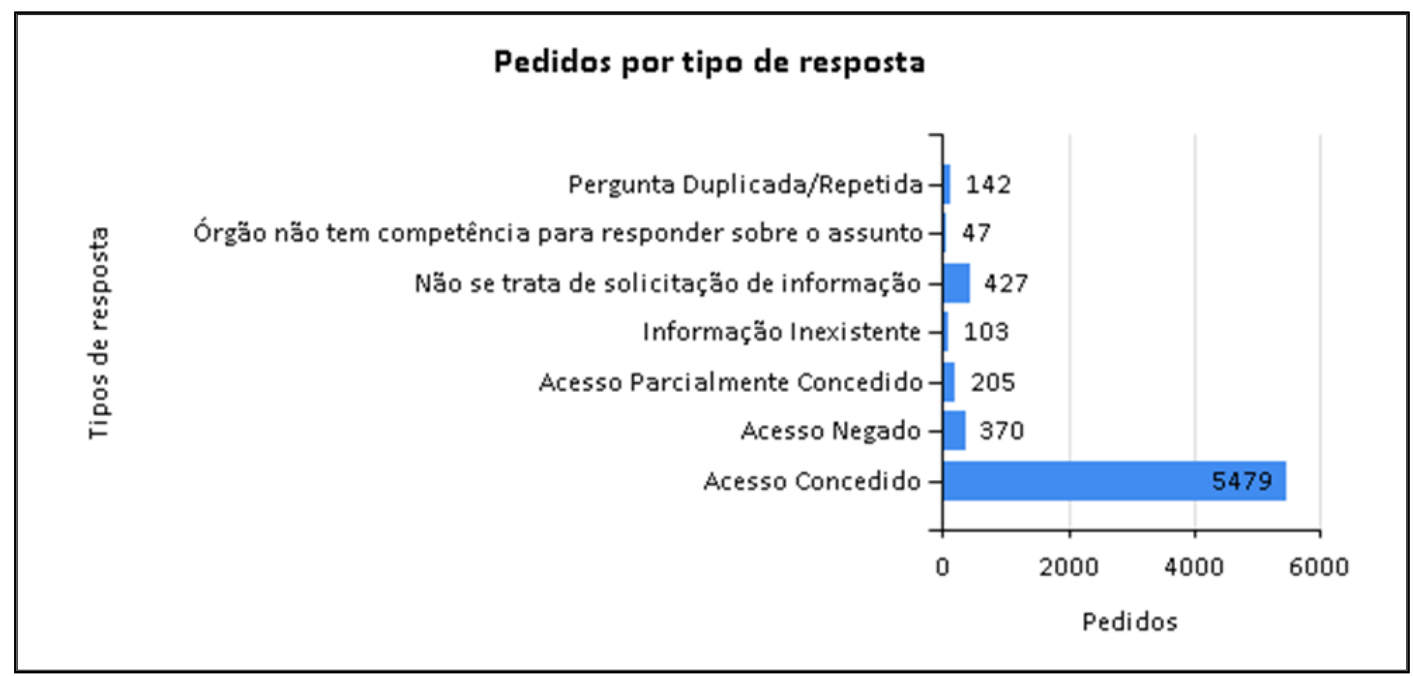

Fonte: Relatório de Pedidos de Informação e-SIC

Fatores como a pressão pelo cumprimento dos prazos da LAI e a insegurança de conceder o acesso a uma informação, antes considerada sigilosa, estiveram presentes nos primeiros anos da implantação da LAI. A quantidade de pedidos de prorrogação do prazo de resposta, como mostramos anteriormente (Gráfico 1), é bem emblemática. Da mesma forma, ao verificarmos o tempo médio de dias para responder aos pedidos de informação. O Gráfico 4 compara os dados da ECT com todos os órgãos da administração pública federal ${ }^{82}$.

${ }^{82} \mathrm{O}$ Tempo Médio das respostas é fornecido no sistema e-SIC através de relatórios ou individualizados, por cada órgão, ou com todos os órgãos da administração pública federal (ADF). Este dado consta no relatório como média, sem os apresentar os valores brutos que possibilitasse comparar a ECT e os demais órgãos da ADF. 
Gráfico 4 - Evolução do Tempo Médio de Resposta (Todos X ECT)

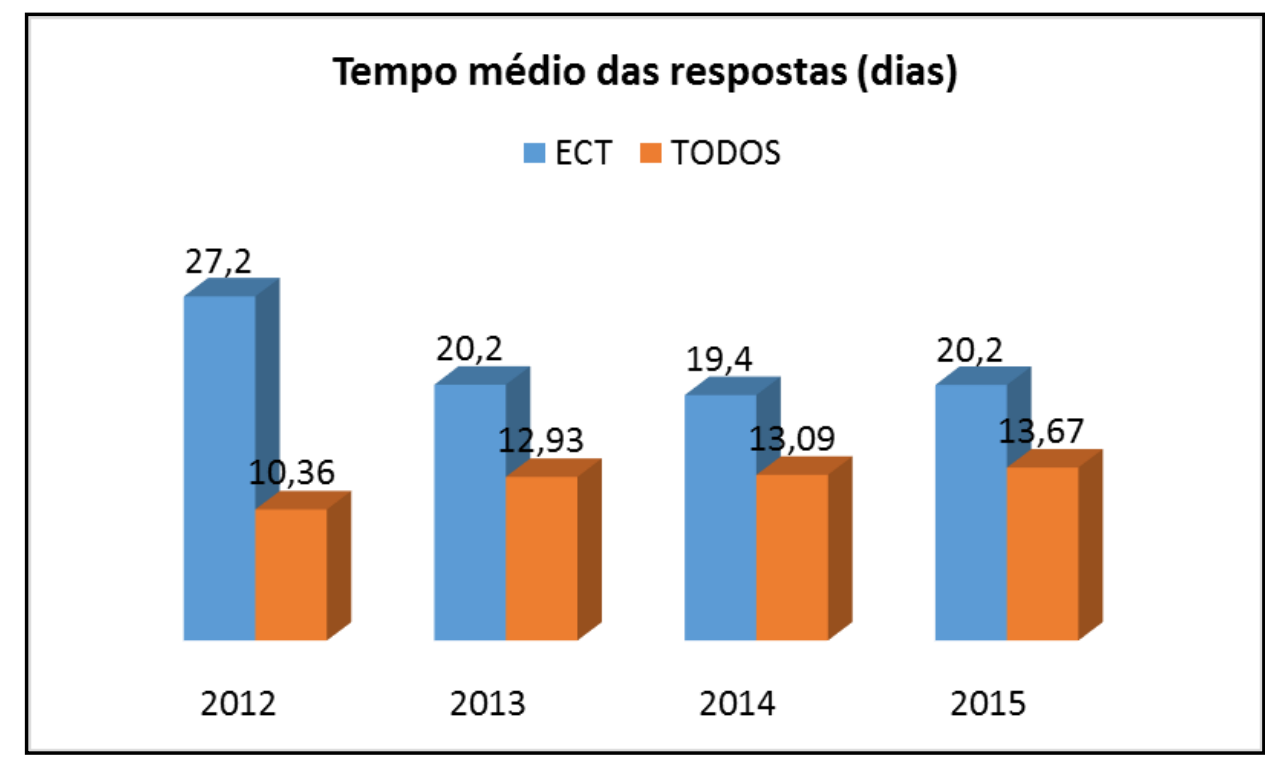

Fonte: Relatório de Pedidos de Informação do sistema e-SIC

O alto percentual de prorrogações no prazo legal de 20 dias, apresentando no Gráfico 1, (seção 2.2.3), e o tempo médio da ECT (Gráfico 4), entre 20 e 27 dias para o envio da resposta ao cidadão, indicam a possibilidade de dificuldades na disponibilização das informações nas áreas gestoras dos assuntos, o que impede os Pontos Focais de cumprirem os prazos legais. $\mathrm{O}$ questionário aplicado aos Pontos Focais busca as respostas à esta questão.

Outro aspecto identificado foram os registros de recursos que chegaram à CGU, pela negativa de acesso à informação, e geraram pareceres que trazem ao debate o caráter público, ou não, da informação produzida pela empresa pública ECT. Os números apresentados abaixo representam a quantidade de pedidos de recurso em cada instância recursal, a partir do total de 6.773 pedidos de informação registrados no SIC - ECT no período analisado. 
Gráfico 5 - Quadro Geral de Recursos por Instância na ECT (2012/2015)

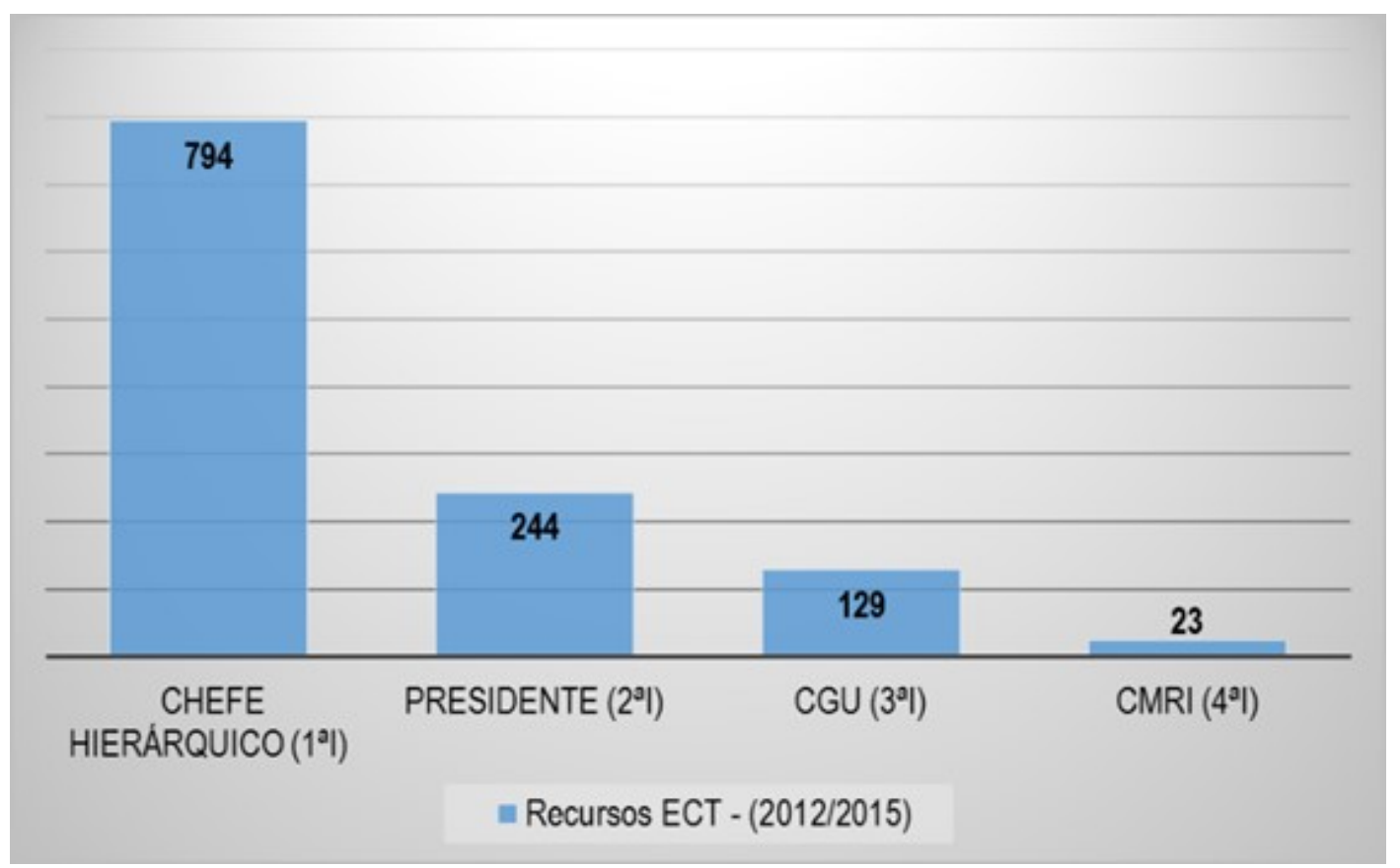

Fonte: Relatório de Pedidos de Recurso do sistema e-SIC

A análise quanto aos recursos está feita de forma comparativa de uma instância para sua anterior. Conforme o Gráfico 5, apenas 794 (11,7\%) dos pedidos iniciais, registraram recurso ao chefe imediato. Entretanto, destes recursos, 244 (30,7\%) não aceitaram a resposta recebida, continuaram insatisfeitos, e registraram recurso de $2^{\mathrm{a}}$ Instância. A insatisfação com a resposta do Presidente da ECT permaneceu para 129 (52,9\%) que recorreram à CGU. Após análise na CGU, apenas $23(17,8 \%)$ levaram o recurso a última instância, à CMRI.

O reduzido número de recursos de $1^{\mathrm{a}}$ Instância refletiu o esforço do SIC-ECT em atender ao cidadão e de atuar como unidade auxiliar na busca da informação, promovendo reuniões entre as áreas e gestores ${ }^{83}$. Portanto, os pedidos que chegaram a recursos de $3^{\text {a }}$ Instância (CGU) revestem-se de questionamentos, muitas vezes complexos, ao envolverem argumentos de sigilo, em função da atividade concorrencial desempenhada pela empresa.

\footnotetext{
${ }^{83}$ Como gestora do SIC, a autora realizou inúmeras reuniões com Pontos Focais e Gestores para sensibilização da abrangência da lei.
} 


\subsection{Os casos: CEP e os 100 maiores salários da DR-PR}

A seguir vamos analisar dois casos nos quais a condição híbrida e a competitividade da empresa são utilizadas para a negativa de acesso.

Caso 1: Código de Endereçamento Postal

Pedido de Informação - NUP 99923.001172/2012-06:

Muitos sistemas necessitam acesso à base de dados do CEP, porém a ECT coloca barreiras técnicas e financeiras ao acesso a estes dados. A falta de acesso livre a esta base de dados causa a disseminação de cópias desatualizadas, o que prejudica não apenas os usuários, mas a própria ECT, uma vez que ela é obrigada a entregar correspondência mesmo com o CEP informado incorretamente. Portanto é do interesse do público e da própria ECT que estes dados sejam oferecidos de forma livre através de uma API (interface de programação) aberta e de fácil utilização. (BRASIL, CGU, Despacho 4775, 2013)

A ECT respondeu com o tipo de resposta "Acesso negado - Informação sigilosa de acordo com legislação específica" informando que o e-DNE é um produto comercializado pela ECT por meio da Correios Online e que "a informação de forma individualizada encontra-se disponível, por meio do Busca CEP, no site www.correios.com.br", pelo qual qualquer cidadão pode consultar gratuitamente o CEP. A ECT alega ainda, que o e-DNE é considerado obra intelectual nova e original, nos termos da Lei. 9.610/1998 (Lei de Direitos Autorais), sob titularidade da empresa. Informa ainda que a ECT “depositou e é legitima titular perante o Instituto Nacional de Propriedade Industrial (INPI) do pedido de Patente de Invenção [...], titulado 'Diretório Nacional de Endereços (DNE)' e perante o German Patent Applicatations, depositou e é legitima titular da extensão da patente de invenção. O solicitante não concordou com a resposta e registrou recurso em que explicita que a LAI no seu art. $8^{\circ}$ prevê o acesso de forma legível das informações produzidas por órgãos e entidades públicas. A ECT respondeu ao recurso com a mesma justificativa da negativa inicial. Em novo recurso, de $2^{\mathrm{a}}$ instância que segue ao Presidente da empresa, o cidadão alega que não pediu o e-DNE e sim a base de dados, afirma que "o e-DNE não corresponde ao pedido original de acesso à uma API aberta e gratuita" 
e mais uma vez trazendo para sua defesa artigos da Lei de Acesso à Informação que garante o acesso em transparência ativa, por meio eletrônico e gratuito aos dados produzidos. Após mais uma negativa, interpôs recurso à CGU.

No parecer objeto do Despacho ${ }^{\circ} 4.775$, de 20/06/2013, do Ouvidor-Geral da União (OGU), assinado também por dois Analistas de Finanças e Controle da CGU, há uma desconstrução da resposta da empresa. Nele os técnicos analisam a Lei de Patentes e argumentam que o conteúdo de banco de dados não é objeto patenteável e, caso tal ocorra, “poderá vir a ser objeto de declaração de nulidade, por força do art. 46 da Lei 9.279/1996" Destaca ainda que o depósito de pedido de patente não gera senão a expectativa de um direito, a ser ou não confirmado mediante a outorga da carta patente, e não tem o poder de configurar hipótese legal de sigilo. O parecer faz ainda uma análise histórica do CEP quanto à sua natureza pública, quando foi desenvolvido em substituição às Zonas Postais ou Zonas de Correio, criadas pelo DCT. Com a publicação do Decreto-Lei 509/1969 ${ }^{85}$, todo capital proveniente da União, que estava a serviço, ou à disposição do DCT, passou à ECT e que ao longo destas quase cinco décadas o CEP passou a ser usado em todo território nacional, estando em placas sinalizadoras de logradouros na maioria dos munícipios brasileiros. A CGU questiona o fato de a ECT nunca ter impedido que estes fossem divulgados. Na avaliação da CGU tal comportamento da empresa é de que a informação era de interesse público e devia ser divulgada. Destacaram ainda, o fato da lista (em papel), com o registro agregado dos CEP, ser disponibilizada em toda agência da ECT e que ficava ao alcance do cidadão. O que é uma realidade na lembrança de todos os brasileiros, até a década de 1990. A CGU analisa ainda os artigos da CF que determinam ser de competência da União manter o serviço postal e o correio aéreo nacional.

Em outras palavras, situa-se o desenvolvimento e atribuição de indexação a logradouros verdadeiro serviço público uti universi, que, apesar de servir ao bom desempenho da atividade econômica, com ela não se confunde." Entretanto, a CGU entende que somente pode dar provimento ao objeto existente e que por solicitar providências, a solicitação estaria fora do escopo do juízo recursal. Assim, não deu provimento e sugeriu a ECT que "tome as medidas adequadas para, em tempo futuro, disponibilizar a informação solicitada em transparência ativa, conforme determina $o$ art. $8^{\circ}$ da Lei 12.527/2011. (OGU/CGU, Despacho nº 4.775, p.6).

\footnotetext{
${ }^{84}$ Esta lei regula direitos e obrigações relativos à propriedade industrial.

${ }^{85}$ Decreto-Lei de criação da ECT em 1969
} 
Em 2013, mais um dos vários pedidos recebidos na empresa solicitando a base de dados do CEP seguiu para recurso de $3^{\text {a }}$ Instancia a CGU, o NUP 99923.000436/2013-87 ${ }^{86}$. No recurso o cidadão argumentou que a empresa não poderia comercializar uma informação pública, exemplificando a hipótese de o TCU comercializar seus pareceres. Após analisar todas as documentações apresentadas pela ECT, a CGU realizou duas reuniões com a empresa, em que novos argumentos foram apresentados. A CGU frente ao dilema identificado, encaminhou consulta à Comissão Mista de Reavaliação de Informações (CMRI), apresentando os oito argumentos da empresa.

15. Oito são os argumentos dos quais faz uso a Empresa Brasileira de Correios e Telégrafos para negar acesso à base de dados de Códigos de Endereçamento Postal: (1) o direito de exploração mercantil da informação que lhe conferiria a Lei Postal, (2) o direito de propriedade intelectual que lhe conferiria o depósito de pedido de patente de invenção junto ao INPI, registrado sob número PI 0.204.305-0, (3) o sigilo comercial, (4) o caráter não público da informação solicitada, (5) o risco à competitividade decorrente da publicização, (6) o art. 13, III do Decreto 7.724/2012, considerando não atendível o pedido diante da necessidade de trabalho adicional de consolidação de dados e informações. (7) adicionalmente, faz menção ao art. $5^{\circ} \S 1^{\circ}$ do Decreto $7.724 / 2012$ para inserir o debate na proteção especial às informações das empresas públicas e (8) alude a que o caráter geral da Lei de Acesso à Informação afastaria a sua aplicabilidade em face da especificidade da matéria tratada pela Lei Postal. (BRASIL, OGU/CGU, Parecer 3012/2013, p. 4)

A CGU apresenta, no ofício à CMRI, a análise de cada um dos oito itens, inclusive com resgate histórico do caráter público da informação, quando das listas impressas, da sua utilização por prefeituras nas placas de sinalização, destaca a Lei Postal no art. 15 em que expressamente não há sinalização para sua comercialização, apenas para autorização da edição e reprodução total ou parcial.

Art. 15 - A empresa exploradora do serviço postal é obrigada a manter, em suas unidades de atendimento, à disposição dos usuários, a lista dos códigos de endereçamento postal.

$\S 1^{\circ}$ - A edição de listas dos códigos de endereçamento postal é da competência exclusiva da empresa exploradora do serviço postal, que pode contratá-la com terceiros, bem como autorizar sua reprodução total ou parcial.

$\S 2^{\circ}$ - A edição ou reprodução total ou parcial da lista de endereçamento postal fora das condições regulamentares, sem expressa autorização da empresa exploradora do serviço postal, sujeita quem a efetue à busca e

\footnotetext{
${ }^{86} \mathrm{O}$ relatório está disponível em

$<$ http://www.acessoainformacao.gov.br/precedentes/ECT/99923000436201387.pdf>
} 
apreensão, dos exemplares e documentos a eles pertinentes, além da indenização correspondente ao valor da publicidade neles inserta.

$\S 3^{\circ}$ - É facultada a edição de lista de endereçamento postal sem finalidade comercial e de distribuição gratuita, conforme disposto em regulamento. (BRASIL, Lei $\mathrm{n}^{\mathrm{o}}$ 6.538/1978)

Por fim, ressalta ser o CEP imprescindível à manutenção do serviço postal no Brasil, e assim, indispensável ao correto desempenho de competência constitucionalmente atribuída à União (inciso X, art. 21 da CF) de manutenção do serviço postal, e considera pouco defensável a tese de que o acesso à informação represente risco de competitividade ou governança à ECT.

49. O dilema que o dispositivo nos impõe, ao considerarmos pública a informação relativa ao Código de Endereçamento Postal, diz respeito ao conflito entre a vedação de cobrança por disponibilização de informação pública e uma herança pretérita à nova legislação, que da informação pública fez produto comercializado. Note-se que não se divisa proibição expressa à venda do produto e-DNE, porquanto se presuma que nele haja valor agregado em forma de suporte ou leiaute de base de dados, justamente aquilo que a legislação permite a cobrança por reprodução, salvo hipótese excepcionalmente prevista na Lei 7.115/1983. (Ibid, p.14) [...]

60. Pelo exposto, delimita-se a antinomia como conflito real entre o art. $5^{\circ}$, inciso XXXIII da Constituição, combinado com o art. 12 da Lei $12.527 / 2011$ e o art. $5^{\circ}$, caput e incisos XXII e XXVII e art. 173, $\$^{\circ}$, II da Constituição Federal, combinados com o art. $3^{\circ}$ da Lei

9.610/1998. Tal antinomia somente poderá ser superada mediante a solução de divergência administrativa, nos termos do art. 10, III do Regimento da Comissão Mista de Reavaliação de Informações, acerca da natureza da informação solicitada, visto que, hipóteses auto excludentes, se de natureza pública, não terá natureza patrimonial, e se de natureza patrimonial, não terá natureza pública.

61. Diante de tal fato, sugere-se a subida do presente à Comissão Mista de Reavaliação de Informações, para que, nos termos do art. 10, III, da Resolução $\mathrm{n}^{\mathrm{o}} 1$ da CMRI e no exercício da competência que lhe é atribuída pelo art. 47, V do Decreto 7.724/2012, se pronuncie sobre a natureza da informação, nos termos reproduzidos no $\S$ supra e referende, se assim decidir, o caráter público da informação solicitada ou, de forma diversa, seu caráter patrimonial. (Ibid, p.18/19)

Em 3 de outubro de 2013, a CGU recebeu o oficio n 2078/Gab-Casa Civil, de 30 de setembro, em que informa a deliberação da $12^{\mathrm{a}}$ reunião ordinária da CMRI de restituir o processo à CGU “[...] para essa Controladoria-Geral da União-CGU proceda a análise do mesmo à luz da Lei Postal nº 6.538/1978.[...]”. A CGU considerou que a resposta oferecida pela CMRI não respondeu à questão de repercussão geral e interpretou que a CMRI considerou a prevalência do art.15 da Lei 6.538/1978 (Lei Postal) sobre o art. 12 da Lei 12.527/2012 (LAI), admitindo assim, que possa uma informação pública ser objeto de comercialização, e que sua natureza patrimonial decorre da possibilidade de comercialização, e não de pré-existência de 
direito de propriedade que sobre ela exista na esfera pública. O parecer final entende ainda que foi apenas uma consulta e que não seria empecilho para o requerente apresentar recurso à CMRI. Entretanto, nenhum dos pedidos sobre acesso a base do CEP seguiu à CMRI, até a conclusão de nossa pesquisa.

A base de dados do CEP é informação frequentemente solicitada, e sua disponibilização é assunto polêmico inclusive no interior da empresa. A área gestora do e-DNE, responsável pela área de logística e produtos comercializados, defende a posição de restrição de acesso a qual mantém-se como resposta aos pedidos recebidos. Gestores da área operacional consideram que, para a empresa, seria mais lucrativo sua distribuição gratuita, uma vez que cerca de $20 \%$ das devoluções de correspondências advém de erro no CEP, o que traz retrabalho e prejuízos ${ }^{87}$. Entretanto, até o presente momento, não foram realizados estudos oficiais, audiências públicas ou qualquer outro movimento para ampliar essa discussão. $\mathrm{O}$ cidadão continua apenas com acesso um a um no "Busca CEP”, disponível na página dos Correios.

Em artigo publicado na internet intitulado "Por que o CEP deve ser tratado como informação pública?" (SANTINI ET AL, 2015), as decisões da ECT e CGU, são objeto de crítica pública. O questionamento no artigo é de como uma base pública, de interesse público, pode permanecer fechada, sendo acessível apenas a quem tem dinheiro. Este é um exemplo onde o caráter híbrido da empresa, no caso, o lado empresarial, sobrepõe-se ao lado público na disponibilização da informação pública.

Caso 2: Os 100 maiores salários da DR-Paraná

Pedido de Informação - NUP 99923.001660/2013-96:

a) nome, matrícula dos 100 maiores salários da DR Paraná e dos respectivos salários com todos seus acréscimos definido em lei, referente ao mês de novembro e dezembro $2013 .^{88}$

A questão de divulgação dos salários foi um dos temas que mais esteve presente quando a LAI entrou em vigor. Inúmeras matérias de jornais abordaram o tema e na ECT a resistência foi muito grande. Na ocasião, o chefe da Central de Gestão de Pessoas se negou a encaminhar

\footnotetext{
${ }^{87}$ Esta afirmação foi feita pelo Gerente de Operações em reunião realizada na sede da CGU no dia 19/02/2016, na presença desta autora, do Ouvidor Geral da União, Gilberto Waller Junior e da Coordenadora de Recursos, Erica Bezerra, para tratar de outro recurso referente aos mapas de Salvador e Alagoinha na Bahia.

${ }^{88}$ O Relatório com o Parecer da CGU deste pedido de informação está disponível em $<$ http://buscaprecedentes.cgu.gov.br/busca/dados/Precedente/99923001660201396_CGU.pdf>
} 
a tabela de remuneração dos dirigentes para a página da LAI, e quando registrado o primeiro pedido de informação sobre essas remunerações o gestor e o Vice-Presidente, no recurso de $1^{\mathrm{a}}$ instância, negaram. Ao chegar o recurso ao Presidente da empresa, ele ordenou a imediata publicação na internet e o gestor foi afastado da função. A partir de então, sempre que as tabelas são atualizadas a própria área gestora encaminha as mesmas para o SIC-ECT para imediata publicação.

As empresas estatais não estão no Sistema Integrado de Administração de Recursos Humanos (SIAPE) utilizado pela administração direta, autarquias e fundações, que disponibilizam no Portal da Transparência o salário bruto e o salário líquido dos servidores públicos federais. Em função da Portaria Interministerial no 233/2012, o GT decidiu divulgar a listagem com o nome dos empregados, cargo ocupado, respectiva referência salarial no Plano de Carreira e, no caso de ser ocupante de função, a denominação da função ocupada. Além disso, divulgou as tabelas salariais, na AC e DRs, e a tabela de funções vigentes.

No pedido de informação 99923.001660/2013-96, a ECT inicialmente respondeu com "acesso negado" alegando que exigia trabalhos adicionais de análise, interpretação e consolidação dos dados e informações, de acordo com o art. 13 do Decreto 7.724/2012, que não era atribuição da empresa e que teria que pedir autorização dos envolvidos, uma vez que alegava tratar de dados pessoais. O trabalho adicional citado pela ECT, referia-se ao fato de ter que separar o Paraná da relação geral e selecionar os 100 maiores. O solicitante registra recurso no qual explicita o art. $7^{\circ}, \S 3^{\circ}$, inciso VI, do Decreto $7.724 / 2012^{89}$, que prevê a divulgação, de forma individualizada, da remuneração e subsídios recebidos por ocupantes da gestão pública, inclusive de emprego público. A empresa mantém a negativa, mas envia a lista de todos os empregados lotados na DR-PR e orienta o requerente a localizar na listagem que está na internet os nomes e as tabelas salarias divulgadas. O cidadão não aceita a resposta e registra novo recurso, agora dirigido ao Presidente da empresa e, mais uma vez, sem sucesso. A CGU, ao receber o recurso de $3^{\mathrm{a}}$ Instância, buscou agir como intermediadora entre o cidadão e a ECT, solicitando informações adicionais à empresa. A ECT alegou que as empresas públicas não estão obrigadas a publicar no Portal da Transparência Pública, de acordo com a Portaria Interministerial $n^{\circ} 233$, de 25/05/2012.

No Parecer $n^{\circ} 2.979$ de 24/07/2014, a CGU afirma que a ECT seria obrigada a disponibilizar, em transparência ativa, a remuneração de todos os seus empregados públicos, 
incluindo seus diretores, conforme os dispositivos legais. A instância recursal também não aceita a alegação de tratamento de dados para este pedido devendo, a empresa, informar o prazo necessário para produzir, uma vez que é sua competência legal e que não há nenhuma informação pessoal que prejudique a vida privada, a honra, a imagem, a intimidade ou que causem prejuízos de ordem moral. Entretanto, ao final afirma que o acesso à informação "passa pela discussão sobre a natureza concorrencial” da ECT. Alega a CGU que a ECT atua em atividade essencialmente econômica, mesmo tendo o monopólio postal o que evidencia o "caráter híbrido em que a empresa atua no mercado". Portanto, ao considerar que a ECT não pode ser caracterizada apenas como prestadora de serviços públicos, o parecer da CGU afirma que "não está obrigada a seguir integralmente as hipóteses do inciso VI, do parágrafo $3^{\circ}$, do artigo $7^{\circ}$, do Decreto $n^{\circ} 7.724 / 12$ e da Portaria Interministerial $n^{\circ} 233$ ”. Com este entendimento, os pedidos de informação sobre salários dos empregados são considerados de acesso negado de acordo com a legislação específica (sigilo comercial).

\subsection{A Cultura Organizacional da ECT e a implantação da LAI}

No capítulo 2 desta pesquisa tratamos o Estado brasileiro e a cultura do sigilo, no item 2.1, e no item 2.3 apresentamos uma análise da ECT, em que destacamos alguns aspectos de sua cultura organizacional. Quanto e como essa cultura organizacional influencia na implantação da LAI?

Segundo Schein (2004, p.304) a cultura organizacional tem suas origens nas crenças, valores e suposições dos fundadores de uma determinada organização; nas experiências adquiridas entre os membros do grupo dessa organização; e em novas crenças, valores e suposições trazidas pelos novos membros e lideranças. Assim, a cultura organizacional pode ser considerada um conjunto de valores, crenças e entendimentos que os integrantes de uma organização têm em comum, que possibilita a coesão da organização, para que possa tomar decisões e desempenhar suas atividades. Schein, por sua vez, enfatiza a cultura organizacional como o resultado da dinâmica de uma determinada organização e que é preciso adotar um modelo de cultura que faça justiça ao que o conceito conota e que possa ter utilidade em outros campos (PIRES, 2006, p.90).

Para Pires (2006, p.100) o desenho organizacional público, na realidade brasileira, normalmente é com formas bastante complexas e níveis hierárquicos múltiplos. 
Essa estrutura demonstra um paternalismo que gera um alto controle de movimentação de pessoal e da distribuição de empregos, cargos e comissões dentro da lógica dos interesses políticos dominantes.

Outra característica marcante é que são estruturas altamente estáveis, que resistem de forma generalizada a mudanças de procedimentos e implantação de novas tecnologias. A cultura da interferência política e administrativa vigente pode ser caracterizada como predominantemente regida por um governo de poucas pessoas e patrimonialista e, também, burocrática e corporativa. É esta cultura que orienta a prática de gestão das organizações públicas. (PIRES, 2006, p.100).

O autor ainda destaca que a história da administração brasileira se repete com dois modelos em permanente disputa, de um lado a burocracia formalista, centralizadora, ineficaz aliada aos interesses econômicos retrógrados e conservadores e, de outro lado, as correntes modernizantes da burocracia e seus próprios aliados políticos e empresariais. Uma quer perpetuar seu controle social e privilégios, e a outra aponta para a globalização e o liberalismo. (PIRES, 2006, p.94 apud CASTOR E JOSÉ, 1998)

Com o objetivo de desenvolver mecanismos institucionais e organizacionais que permitisse à administração pública brasileira promover e assegurar o acesso a informações públicas como um direito fundamental do indivíduo e capaz de contribuir para consolidação da democracia brasileira, em especial, a CGU promoveu, em parceria com a Organização das Nações Unidas para a Educação, a Ciência e a Cultura (UNESCO), sob a coordenação do Professor Roberto da Matta, a elaboração do "Diagnóstico sobre valores, conhecimento e cultura de acesso à informação pública no Poder Executivo Federal Brasileiro” em 2011. A referida pesquisa esteve inserida no contexto do Projeto denominado "Política Brasileira de Acesso a Informações Públicas: garantia democrática do direito à informação, transparência e participação cidadã”, e possibilitou identificar a presença de fatores culturais que favorecem a transição para uma cultura de livre acesso à informação, ou no em sentido contrário, ensejassem a manutenção de uma cultura do segredo. Outro destaque da pesquisa é que os resultados permitem identificar outras condições, de natureza organizacional, operacional e tecnológica dos processos de tratamento da informação, tendentes a facilitar ou dificultar essa mudança (BRASIL/CGU, 2011c, p.3)

Nas conclusões do Sumário-Executivo, os pesquisadores consideram possível afirmar a existência de um movimento em curso, em 2011, de abertura e conscientização sobre a importância da transparência. Verificou-se também que todos os órgãos e entidades participantes da pesquisa desenvolviam algum tipo de prática na área de transparência, com amplo uso das páginas eletrônicas para a publicação de notícias, informações, serviços e/ou relatórios. Pelo diagnóstico a disponibilização ativa de informação reduz os pedidos, 
contribuindo para a relação Estado e sociedade. A pesquisa revelou ainda que praticamente todos os órgãos apontaram iniciativas ou planos de melhoria da gestão de informações e arquivos e de aumento da disponibilidade de informações nos sites. (BRASIL/CGU, 2011c, p.18).

A pesquisa também apontou os desafios que seriam enfrentados para a implementação bem-sucedida da Lei, sendo a cultura do segredo, identificada principalmente na constante preocupação com o "mau uso" das informações pelo público, com a "má interpretação" ou "descontextualização das informações" (BRASIL/CGU, 2011c, p.18). O controle das informações (o que está sendo informado, para quem e com qual objetivo) apareceu como prática recorrente, como um reflexo da visão de que as informações sob a guarda do Estado são tratadas pelos servidores públicos como de propriedade do Estado, como destacado na conclusão da pesquisa.

Para garantir a efetiva aplicação da LAI, o Sumário-Executivo apresenta propostas de mudanças necessárias na Administração Pública Federal em três aspectos: cultural, a organizacional e operacional. No aspecto cultural destaca a definição clara do que é/não é informação pública (para reduzir o arbítrio pessoal para as decisões); enfrentar a complexa cultura do papel, gaveta e pendrive que se reflete na "difusa sensação" que os funcionários públicos são proprietários da informação, disponibilizando ao seu critério; incentivar uma nova cultura de produção e compartilhamento de bancos de dados (aí incluídos aqueles contendo informações primárias). No aspecto organizacional, a proposta de existência de áreas responsáveis pelo recebimento e acompanhamento dos pedidos de informação, que se concretizou com a criação dos SICs, assim como, setores encarregados de supervisionar (foi criado em lei a Autoridade de Monitoramento da LAI em cada órgão); abertura e manutenção de canais eficientes de comunicação entre os órgãos de Estado/governo e a sociedade; implantação de rotinas informatizadas para o fluxo entre solicitações e respostas, o que se concretizou com a disponibilização do sistema e-SIC; programas de sensibilização, treinamento e capacitação dos recursos humanos com foco nas transformações exigidas pela LAI, que foram efetivadas com cursos presenciais e a distância, com apoio da ENAP e está em andamento a política para arquivos de documentos e também para o arquivamento eletrônico nos órgãos da administração federal. Por fim, no aspecto operacional que trata da universalização da gestão eletrônica de documentos e de acompanhamento de processos, com interfaces que permitam o acesso direto dos cidadãos interessados (a implantação do SEI no âmbito da administração pública federal); digitalização de documentos, sites bem desenhados; banco de dados com um mínimo de obstáculos para o acesso ao cidadão comum, e a definição de orçamento que 
possibilite a efetivação de todo esse novo ambiente de acesso a informação pública federal. (BRASIL/CGU, 2011c, p.19/20).

Percebe-se que um conjunto amplo de mudanças sugerido no Sumário-Executivo, ou já foram implementadas, ou em estão em andamento. Entretanto, a realidade de cada um dos órgãos da APF é mais complexa, principalmente autarquias, fundações e empresas públicas com corporações organizadas e estruturas rígidas, mesmo com mudanças dos nomes das áreas, departamentos, gerencias, continuam no ciclo corporativo e distante da sociedade. Pires destaca o afastamento das organizações públicas para o atendimento das necessidades dos cidadãos.

\begin{abstract}
A cultura de organizações públicas leva essas mesmas organizações a burocracias públicas tradicionais que além de terem se tornado complexas, com características centralizadoras e estruturas rígidas, não têm sido orientadas para o atendimento das necessidades dos cidadãos, ou para a eficácia e efetividade. Para tanto, difundem-se no setor público inovações consideradas exitosas no setor empresarial, sem que se considerem objetivos e valores predominantes na administração pública. (PIRES, 2006, P.100)
\end{abstract}

O diagnóstico apresentado no Sumário-Executivo da pesquisa se enquadra no ambiente da ECT. Junquilho e Leite da Silva (2004) realizaram estudos sobre os aspectos culturais existentes entre os funcionários dos Correios, de uma determinada regional ${ }^{90}$, e identificou a existência de uma cisão na empresa entre a área operacional e administrativa, além da separação entre gestores e trabalhadores na área operacional (TEIXEIRA, 2013, p.214).

Como já destacado neste estudo, as relações de trabalho na ECT estavam baseadas no autoritarismo militar (Teixeira, 2013, p.53). A lógica militarista que valoriza e enfatiza a disciplina, a ordem e a hierarquia tornaram-se parte das práticas cotidianas, presente em todo o processo operacional e organizacional da empresa, segundo o autor. As contestações às ordens e às rotinas de trabalho além de ignoradas eram combatidas e perseguidas pelos gestores. Teixeira (2013, p.53) identifica como elementos que estimulam práticas constantes e autoritárias de gestão pelo mecanismo do poder militar, sem necessidade de consenso ou hegemonia; uma legitimidade garantida, portanto, pela força. Uma realidade que se mantém até o presente ano de 2016.

Ao analisar os ambientes organizacionais na DR estudada, Junquilho e Leite da Silva (2004) concluem pela busca de um diálogo entre alta administração e os funcionários. A construção

\footnotetext{
${ }^{90} \mathrm{O}$ estudo empírico dos autores foi realizado na Empresa Brasileira de Correios e Telégrafos - ECT, em 2000, em uma regional específica da região sudeste do País que foi tratada como XYZ.
} 
de um ambiente de confiança e transparência seria fundamental para proporcionar transparência e acesso às informações à sociedade para qual a empresa presta serviços.

\begin{abstract}
Os resultados da pesquisa realizada na XYZ permitiram a caracterização da heterogeneidade e complexidade no cotidiano organizacional, refletindo a empresa como espaço não só de consensos, mas também de diferenciações e fragmentações.[...]. Importa, sim, iniciar um processo de discussão, envolvendo o que é comum e incomum entre valores desejados e a realidade vivida pelos atores, não para tornar consensual o que não pode ser homogêneo, mas permitir a reconstrução de práticas inerentes às intenções de valores organizacionais que, certamente, não vão substituir culturas, mas promover o confronto, o debate, o conhecer, o reaprender.

Portanto, a contribuição da discussão desenvolvida neste artigo está em tornar mais rica e produtiva a ideia de que valores "nas organizações" - e não "organizacionais" - são construídos socialmente - e não, a priori, pelos desejos da alta administração. As "intenções organizacionais", mesmo predefinidas, não seriam ditames, mas uma agenda norteadora para a área de gestão de pessoas. Pode-se, então, imaginar a construção de um diálogo entre a alta administração e os funcionários, baseado no reconhecimento do processo de redefinição de significados no universo organizacional, caracterizado por "consensos", "diferenças" e "fragmentos". (JUNQUILHO; LEITE-DA-SILVA, 2004, p.150)
\end{abstract}

Schein (2004, p.335/6) reforça que a mudança cultural inevitavelmente envolve desapego e reaprendizagem e, portanto, é, por definição, transformadora. Segundo o autor, construir uma organização eficaz é, em última instância, uma questão de mesclar as diferentes subculturas, incentivando a evolução de objetivos comuns, linguagem comum e procedimentos comuns para resolver problemas.

A implantação da LAI na ECT encontrou, inicialmente, grandes barreiras, que inicialmente foram ultrapassadas porque a alta direção da empresa tinha orientações de governo para a garantia de cumprimento da lei. Entretanto, a cultura do segredo para uma cultura do acesso, além dos obstáculos operacionais e técnicos, encontra resistência nos empregados, como identificado no Sumário-Executivo, "o controle das informações, especialmente dos bancos de dados, cria um status diferenciado e garante o espaço político dos técnicos dentro de seus órgãos". É esse poder dentro da ECT que faz persistir a resistência em disponibilizar informações não só para o público, mas às vezes até para outras áreas da própria administração da empresa. No evento de divulgação da LAI na ECT realizado dias 2 e 3 de maio de 2012, o então Vice-Presidente Jurídico chegou a exemplificar tal situação informando que iria usar o SIC para conseguir informações da própria empresa, pela dificuldade de receber informações de outras áreas quando solicitado. 
Nas respostas ao questionário aplicado aos Pontos Focais do SIC, é possível perceber as diferentes subculturas presentes na forma de olhar o que se passa na empresa, de como se dá a gestão documental, a transparência e a implantação da LAI. 


\section{ANÁLISE}

Este capítulo tem o objetivo de organizar e apresentar as informações coletadas no nosso estudo. Nossas fontes de informação têm diversas origens, entretanto refletem o olhar de cada sujeito no processo de cumprimento da Lei de Acesso à Informação na ECT.

Os recursos analisados pela CGU e os relatórios disponíveis no e-SIC, nos apresentam como a empresa está cumprindo a lei quanto aos prazos, aos tipos de resposta, aos recursos recebidos; o Questionário aos Pontos Focais do SIC-ECT espelha as dificuldades, ou facilidades, em atender às solicitações dos cidadãos no ambiente da empresa; o relatório de integridade da CGU, é o olhar do órgão fiscalizador, de monitoramento quanto às condições de transparência prevista na lei e, por fim, a pesquisa de satisfação que é o olhar do cidadão quanto ao atendimento da informação requerida.

A Figura 9, a seguir, representa o espectro de informações analisado, quanto ao cumprimento da LAI na ECT.

Figura 8 - Origem dos Dados Coletados da Pesquisa

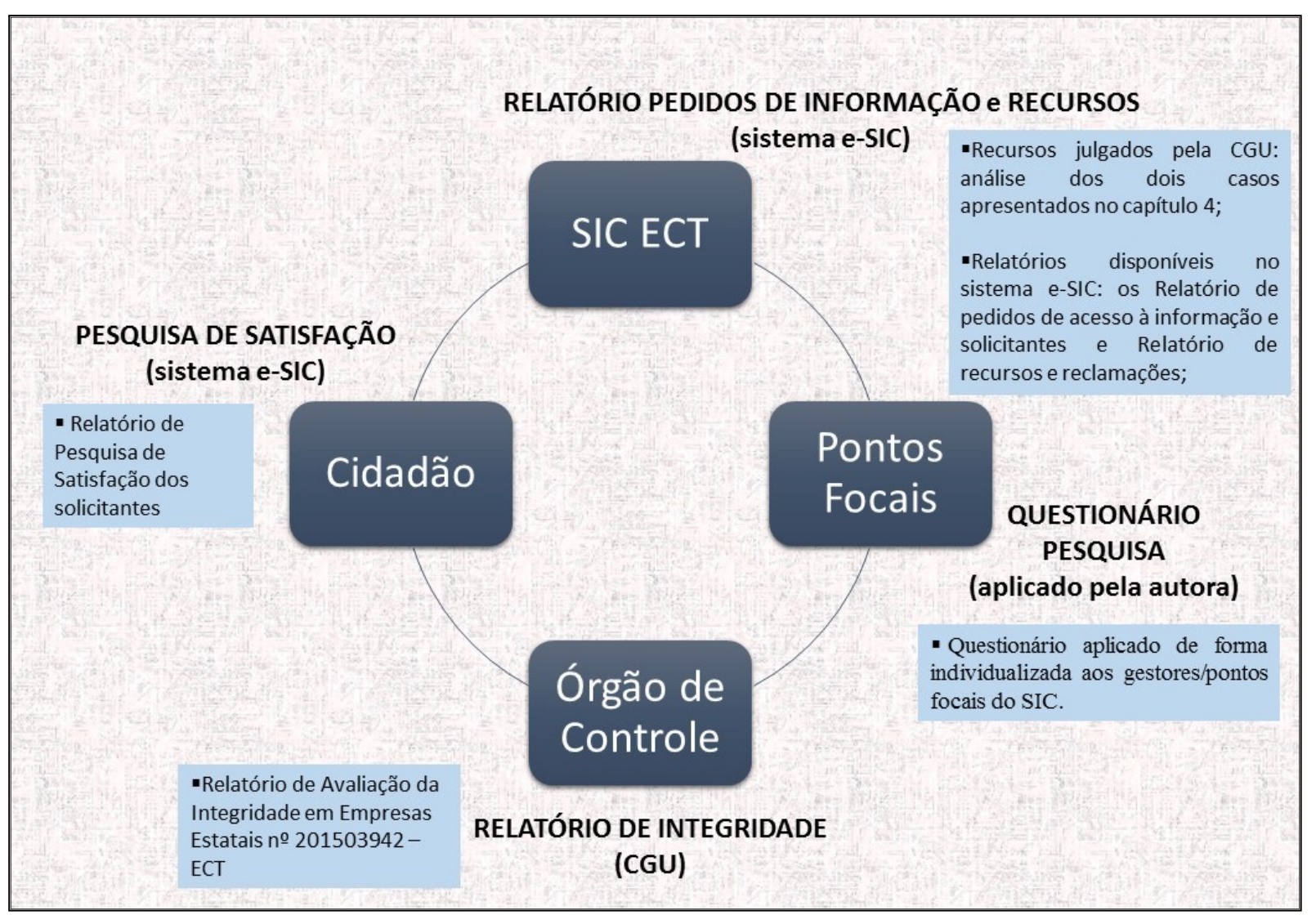

Fonte: Elaborado pela autora 


\subsection{Recursos: CEP e Salários}

No primeiro caso, que trata da disponibilização da base de dados do CEP, pelo parecer da CGU fica evidenciado o seu caráter público, e não de uma informação que deva ser tratada como mercadoria, e comercializada, como praticado pela ECT. O CEP como informação pública deveria estar disponível em Transparência Ativa, Dados Abertos. A interpretação da CGU, à resposta da CMRI, para proceder à análise do pedido à luz da Lei Postal, foi de que deveria se aceitar o caráter comercial do CEP. Com isso o órgão de monitoramento da implementação da LAI se esquivou do enfrentamento do tema. O caput do artigo 15 da Lei Postal estabelece que deve estará disposição dos usuários a lista do $\mathrm{CEP}$, e não um a um. $\mathrm{O}$ parágrafo terceiro do mesmo artigo, ao facultar a empresa a edição da lista de endereçamento postal sem finalidade comercial e de distribuição gratuita, caracteriza que ela é a guardião da informação, que deve zelar por ela e fazer sua gestão, e que é uma informação pública. Nos parágrafos anteriores fica evidente que o legislador aponta caminhos para buscar financiamento para edição da lista para que não significasse um ônus sua reprodução. Completamente inadequado para o mundo eletrônico atual. Na apresentação do ranking de Dados Abertos no mundo, o Brasil deixa de ocupar um lugar mais destacado e um dos fatores importantes nessa classificação é exatamente a não disponibilização do Código de Endereçamento Postal, já disponibilizado por vários outros países. ${ }^{91}$

No segundo caso, a exploração de atividade econômica é o argumento principal para a não observância às disposições da LAI. Os empregados da ECT ingressam por concurso público, as tabelas salariais e os demais itens da remuneração fazem parte de acordos trabalhistas que são definidos em Acordo Coletivo de Trabalho (ACT) com as entidades sindicais, ou mediante negociação no Tribunal Superior do Trabalho (TST), constituindo-se decisões públicas. As tabelas de função são decidas no Conselho de Administração cujas as atas são publicadas na internet, e estão publicadas na página de acesso à informação. Os salários dos servidores e empregados públicos têm regras públicas de definição e teto, portanto informações públicas que não encontram amparo para não serem de acesso público. A argumentação de que

\footnotetext{
${ }^{91}$ Reino Unido, Dinamarca, Colômbia, Uruguai, México, Finlândia, França, Estados Unidos, Holanda etc No Ranking de Dados Abertos na coluna "Location Datasets" é possível verificar o status de liberação das informações ligadas ao CEP de 122 países no mundo, disponível em < http://index.okfn.org/place/>
} 
sua divulgação trará vulnerabilidade na competição de mercado não encontra amparo nas restrições prevista na LAI, para negativa do acesso.

Pelo contrário, a transparência dessas informações aumentaria a confiança externa e interna na empresa. Após décadas de ambiente de sigilo e opressão, muitas questões relacionadas à progressão funcional e ascensão na cadeia de poder da empresa, sem critérios amplamente conhecidos e discutidos, trouxeram dúvidas sobre a qualificação e competência de muitos gestores. A transparência na tomada de decisões, a partir do processo administrativo, não existia há cinco anos.

Assim como, no Senado, em que ex-presidentes temiam a revelação de seus atos, ainda estando vivos, há no sigilo das informações na área de gestão de pessoas na ECT, uma nuvem de fumaça sobre decisões tomadas por gestores, ainda em plena atuação na empresa.

O CEP é uma informação indispensável para a manutenção do serviço postal, uma vez que qualquer que seja o objeto - exclusivo do monopólio ou atividade econômica - sua entrega pode ser prejudicada pela inexatidão do CEP. Há prejuízos na prestação de serviços públicos para a população e, portanto, esta é uma informação fundamental para o cumprimento do preceito constitucional de manter o serviço postal.

\subsection{Relatório do Sistema e-SIC}

O recorte temporal de nosso estudo compreende o período de 16 de maio de 2012 à 31 de dezembro de 2015. Os dados serão apresentados separando cada ano ou aglutinado no período estudado. As tabelas foram elaboradas com base nos relatórios disponibilizados na página na internet do Sistema Eletrônico do Serviço de Informação ao Cidadão (e-SIC) Relatórios Estatísticos. Todos os pedidos de informação atendidos na ECT estão registrados no sistema e-SIC. Pelo objeto de nosso estudo, analisaremos os pedidos de informação e recursos.

O perfil do solicitante do SIC-ECT não difere daquele em âmbito nacional, ou seja, a maioria é composta de pessoas físicas, que representam $95 \%$ dos solicitantes. A maioria das pessoas jurídicas são as pequenas e médias empresas e na pessoa física, o maior percentual encontra-se na opção "outra” (27\%), seguida de empregado do setor privado (26\%). Somando as opções "outra" e "não informado", temos 43\% dos requerentes sem identificar a sua ocupação. Como essas informações são registradas no momento do cadastro no sistema e-SIC, 
e há várias opções, esse dado pode ser reflexo da obrigação de se identificar, constante na lei, e o desejo do solicitante em não ser identificado ${ }^{92}$ na tramitação do pedido dentro da empresa.

Quanto à pessoa física, o gênero masculino é a maioria dos solicitantes, representando $58,8 \%$, com aumento na participação do gênero feminino que iniciou com $21,8 \%$ e está com $37 \%$ de participação.

Gráfico 6 - Perfil do Solicitante ECT: Tipo de Pessoa (2012/2015)

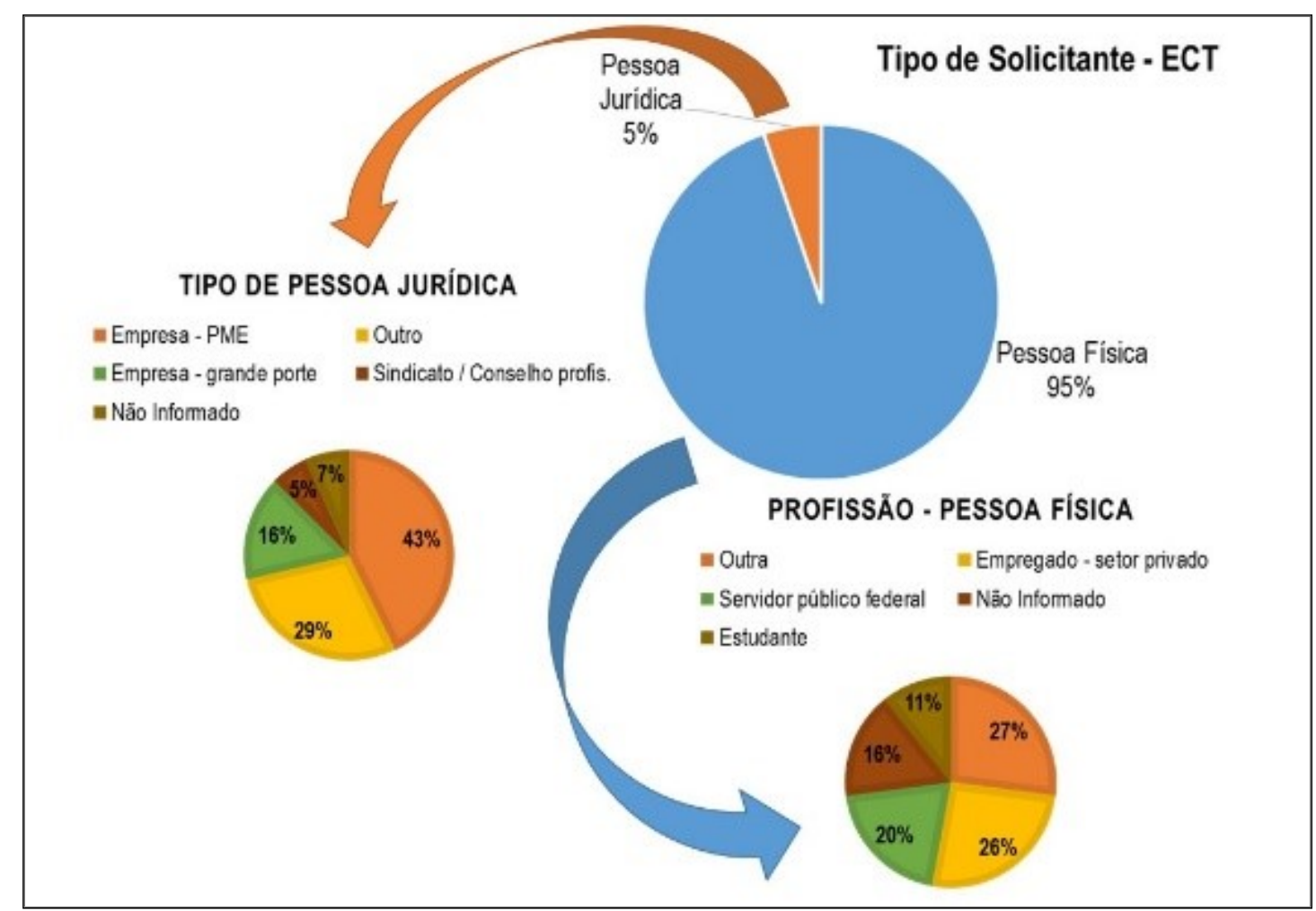

Fonte: elaborado pela autora com base nos relatórios do Sistema e-SIC

Os dados extraídos dos relatórios do sistema e-SIC indicam o crescimento de pedidos de informação nos três primeiros anos da LAI. A ECT mantém uma média de 1.700 pedidos ao ano (Gráfico 7). Foram 1.181 pedidos de informação de maio de 2012 a dezembro; 1.645 no ano de 2013; 2.213 no ano de 2014 e 1.734 no ano de 2015. No total foram registrados de maio de 2012 à dezembro de 2015, 6.773 pedidos de informação.

Gráfico 7 - Evolução dos Pedidos de Informação e-SIC/ECT

\footnotetext{
${ }^{92} \mathrm{O}$ cidadão quando se registra no sistema e-SIC tem como campos obrigatórios o nome, o CPF e e-mail. Entretanto, no campo "nome" o cidadão pode colocar um nome incompleto ou até um nome fantasia.
} 


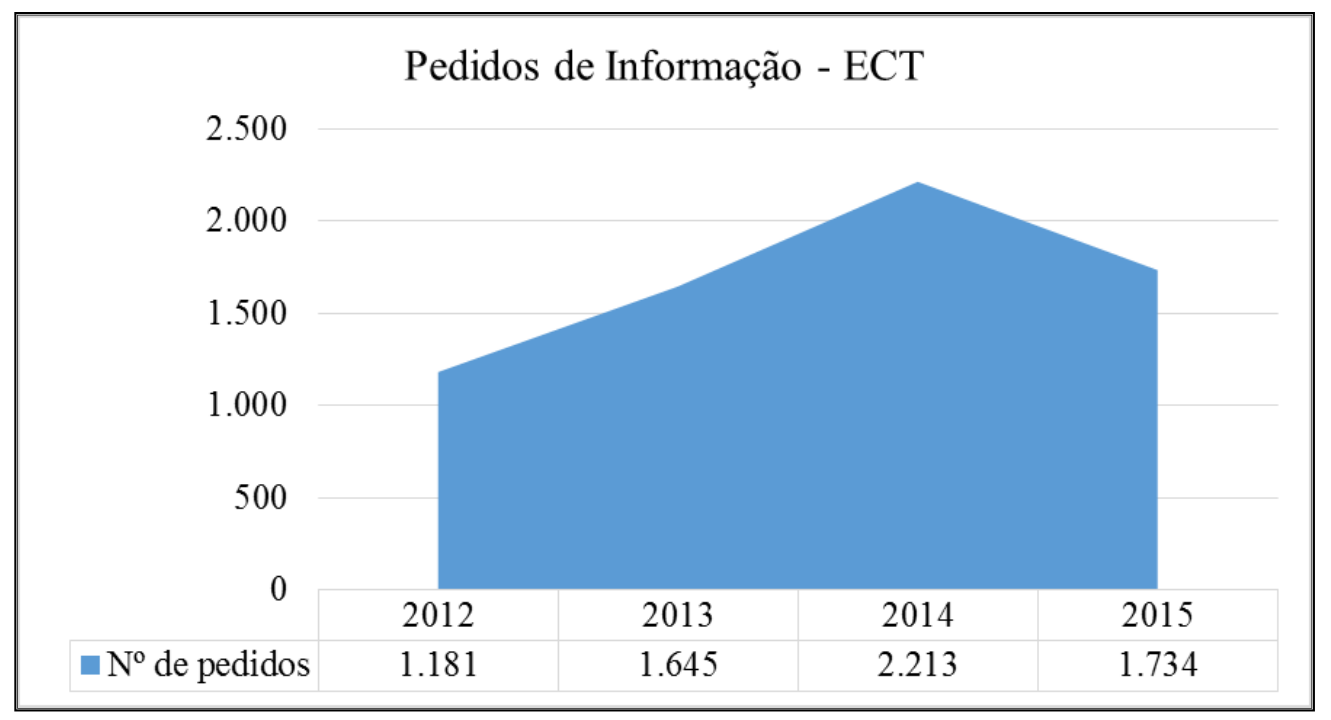

Fonte: elaborado pela autora com base nos relatórios do Sistema e-SIC

Tabela 6 - Estatais mais demandadas (2014)

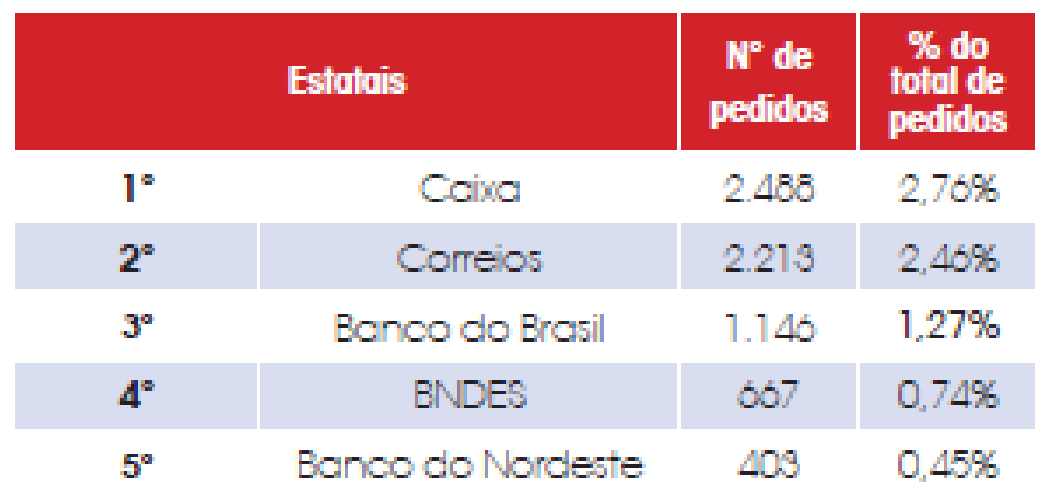

Fonte: Relatório sobre a Implantação da Lei 12.527/2011/CGU

Os principais temas solicitados são os que tratam de "Ciência, Informação e Comunicação" caracterizados como solicitação de cópia de documentos, contratos, patrocínio etc.; seguido das questões relativas ao "Trabalho, Política trabalhista", pedidos caracterizados como relativos à gestão de pessoal (Gráfico 8). É importante destacar que os Correios realizaram Concurso Público ${ }^{93}$ em 2011, com 9.190 vagas, em que concorreram mais de 1 (um) milhão de candidatos, e muitos utilizaram o SIC para informações sobre questões relativas ao

\footnotetext{
${ }^{93}$ Informações sobre o Concurso Público de 2011 estão disponíveis em na página na internet dos Correios $<$ http://blog.correios.com.br/correios/?p=3679>.
} 
concurso. A demanda sobre informações relativas ao tema "Trabalho, Política trabalhista" reduziu à metade de 2013 para 2014.

Gráfico 8 - Principais Temas das solicitações (2012/2015)

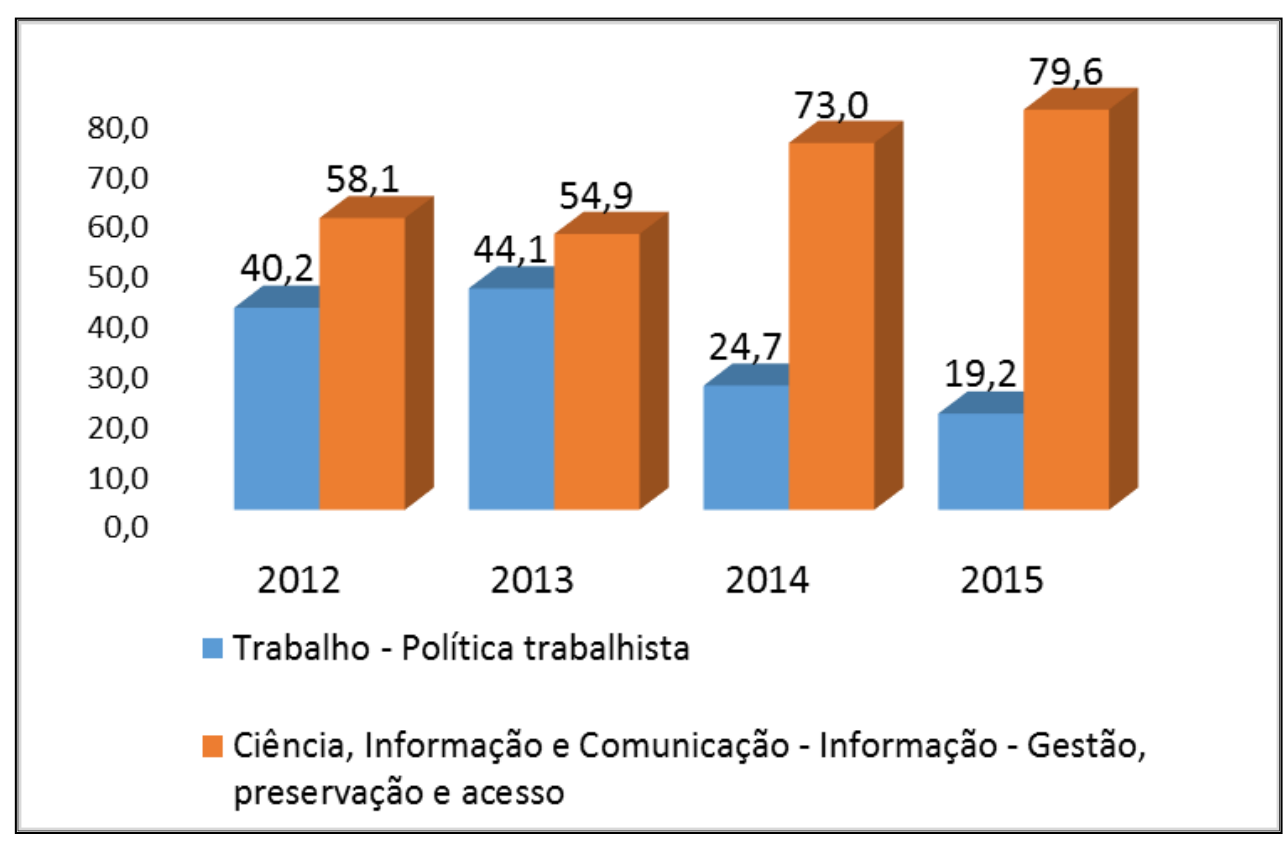

Fonte: elaborado pela autora com base nos relatórios do Sistema e-SIC

Quanto as razões para a negativa de acesso às informações (Gráfico 9), em 2012 "Pedido Genérico", seguido dos "Dados Pessoais" e "informação sigilosa de acordo com a legislação específica" eram os fatores principais da maioria das negativas, com 28,2\% e 23,9\%, respectivamente. A partir de 2013, as razões de negativa de acesso passaram a ser a classificação majoritariamente "informação sigilosa de acordo com a legislação específica" que tem um índice de 37 a 38,8\%. É neste item que o uso de sigilo comercial é utilizado para a negativa de acesso, utilizando a condição híbrida da empresa como justificativa. 
Gráfico 9 - Razões para a Negativa de Acesso a Informação (2012/2015)

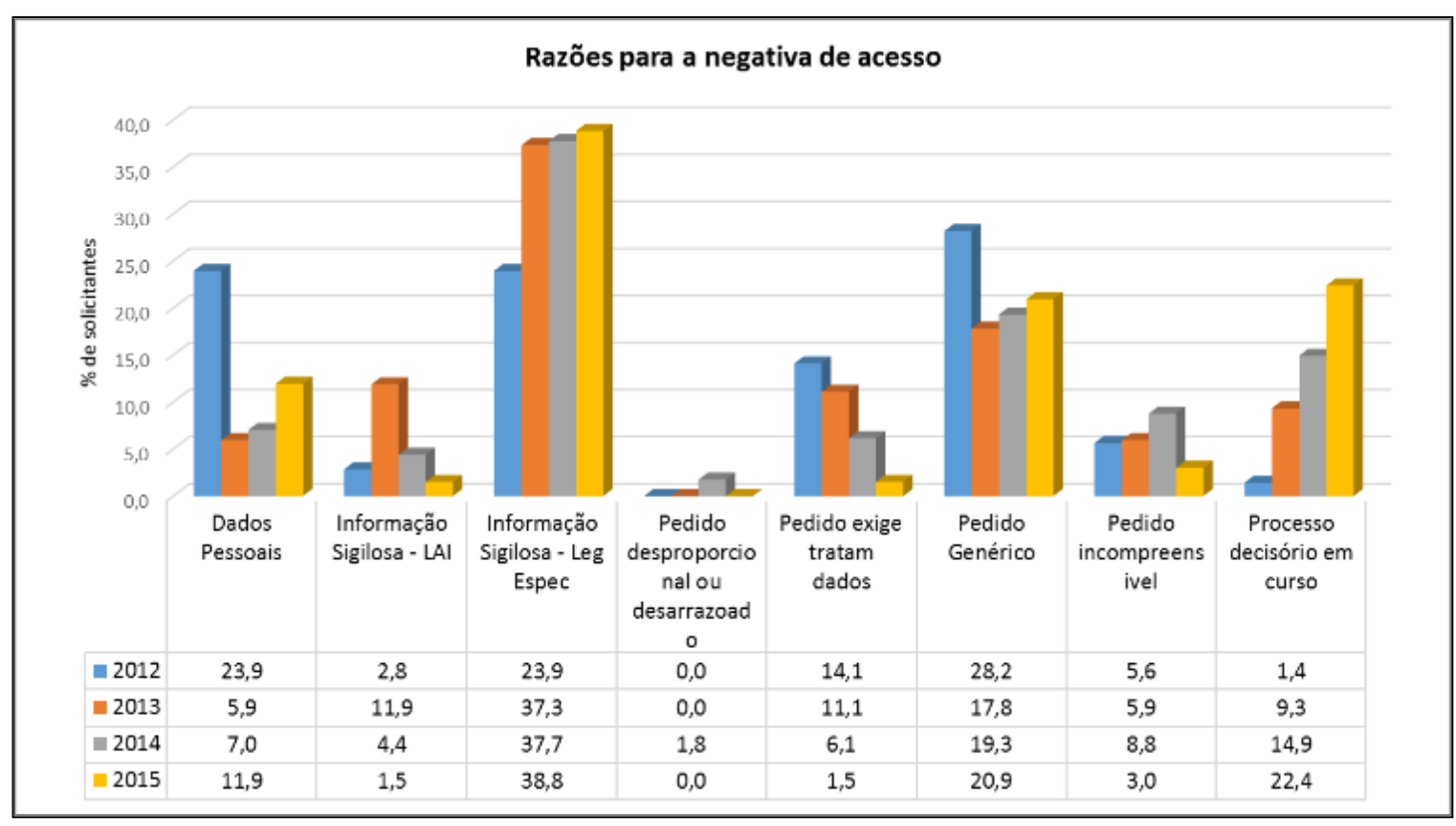

Fonte: elaborado pela autora com base nos relatórios do Sistema e-SIC

E, por fim, os motivos que levaram os cidadãos à registrarem seus recursos. A maioria dos solicitantes alega que a empresa não respondeu ao que foi solicitado, indicando "informação incompleta" e "informação recebida não corresponde à informação solicitada", motivos que chegam a 60\% dos recursos (Gráfico 10). Foram registrados 713 recursos de $1^{\mathrm{a}}$ Instância; 217 recursos de $2^{\mathrm{a}}$ Instância; 112 recursos de $3^{\mathrm{a}}$ Instancia (CGU) e 20 recursos de $4^{\mathrm{a}}$ Instancia (CMRI). Percebemos também que os recursos que chegaram a última instância, a CMRI, se dividem em "informação recebida não corresponde à informação solicitada" e "Justificativa para o sigilo insatisfatória/não informada". Ou seja, a informação continuou sendo negada e analisando as razões para negativa de acesso, é possível que se tratassem de informações sigilosas - legislação específica (sigilo comercial, sigilo empresarial). 
Gráfico 10 - Principais Motivos para Recurso (2012/2015)

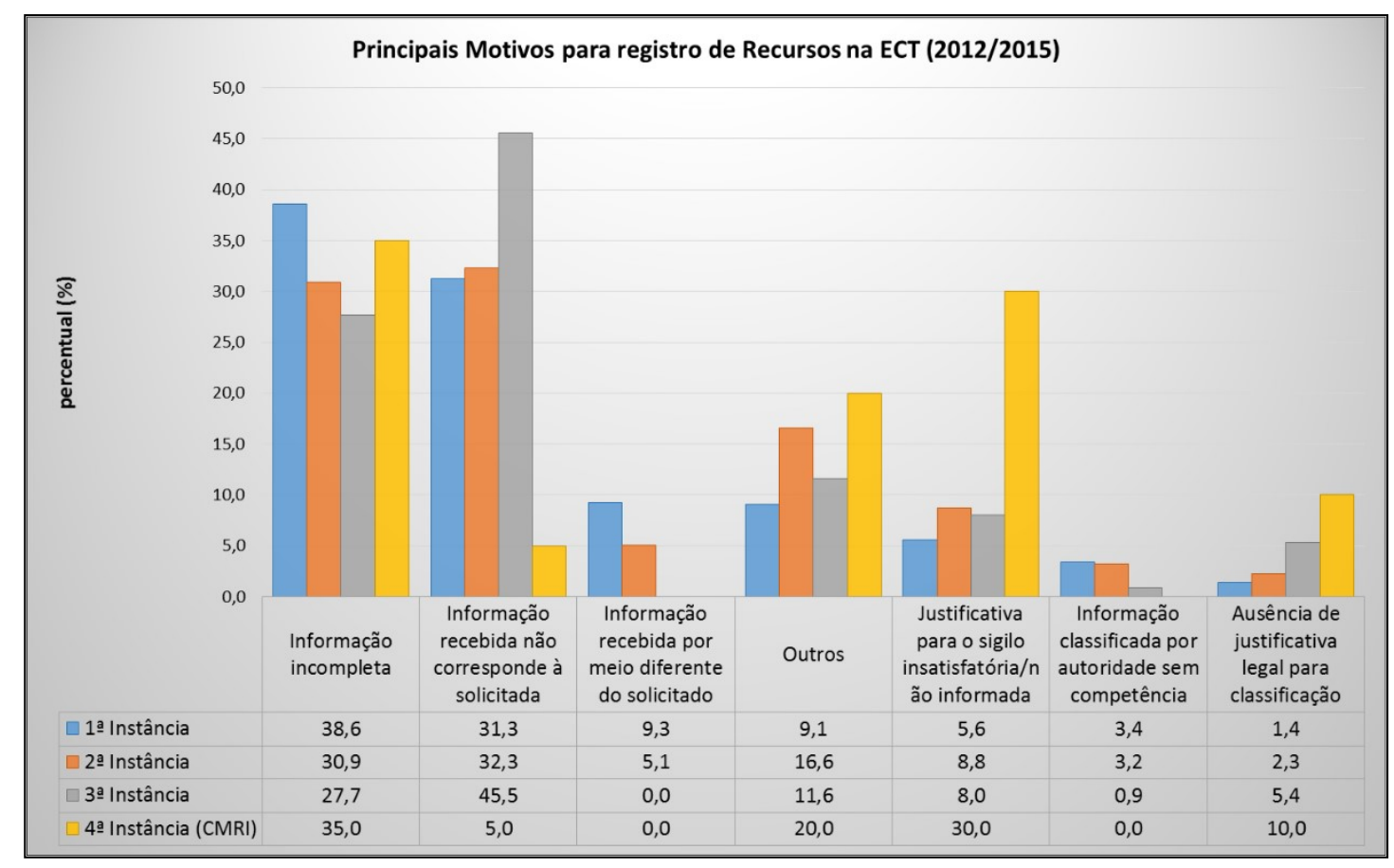

Fonte: elaborado pela autora com base nos relatórios do Sistema e-SIC

\subsection{Questionário aplicado aos Pontos Focais}

O questionário contém 50 itens, organizado em 5 (cinco) blocos. Os blocos 1 e 2 se destinam a traçar um perfil do respondente em função da faixa etária, tempo de serviço na empresa, e de atuação junto à LAI. Já os blocos 3 e 4 tratam de requisitos relacionados à Organização da Informação, e no bloco 5, buscamos identificar os requisitos de disponibilização da Informação pela ótica do Ponto Focal.

Para os blocos 3, 4 e 5, os entrevistados dispunham de seis alternativas: "discordo completamente - DC"; "discordo parcialmente - DP"; "nem discordo, nem concordo - NDNC"; “concordo parcialmente - CP”; “concordo completamente - CC”; e "desconheço - D”.

A utilização do questionário propiciou a vantagem de atingir os pontos focais nas Diretorias Regionais, a flexibilidade de respondê-lo quando julgassem mais conveniente e a não exposição do Ponto Focal à influência das opiniões do entrevistador. A extensão do questionário, e pequeno prazo para a resposta por motivos alheios a nossa vontade, pode ter sido uma limitação para o número de respostas, que poderia ter sido um pouco maior. Apesar 
de questionários poderem apresentar resultados não esperados, já que os itens podem ter significados diferentes para cada respondente, a avaliação é que o instrumento de avaliação cumpriu seu objetivo, isto é, nos ajudar a responder as questões levantadas quanto do caráter híbrido da empresa e a cultura organizacional influenciarem a implantação da LAI na ECT.

O questionário possuiu características que convergem para uma validade de conteúdo. No cabeçalho, foi realizada uma apresentação sobre objetivos da pesquisa e respectivas instruções de preenchimento para familiarizar o respondente com o questionário. $\mathrm{O}$ questionário foi enviado a um total de 60 empregados dos Correios, que atuam, ou atuaram na implantação da LAI, como Pontos Focais (PF) do SIC, nas suas unidades de trabalho. O questionário foi enviado por meio do correio eletrônico institucional, entre os dias 02 a 08/05/2016, com prazo de retorno até o dia 20/05/2016. Do universo pesquisado, recebemos o retorno de 35 respostas $(58,3 \%)$. O objetivo deste método é analisar, através dos responsáveis pela tarefa de atender a demanda do cidadão, como compreendem a organização da informação e como percebem a transparência pública na empresa.

Os resultados foram analisados por meio de estatística inferencial simples. Os dados foram processados em planilha eletrônica de dados que geraram os gráficos. Todas as tabelas apresentadas foram elaboradas pela autora com base nas respostas aos questionários.

Bloco 1 - Identificação do servidor

Este bloco contém 6 (seis) perguntas/afirmativas: identificação, cargo, ano de ingresso, função ocupada, formação acadêmica e ano de nascimento. A resposta a estas questões nos apresentou um perfil majoritário de empregados com pós-graduação, ocupando cargos de nível superior na carreira e função de assessoramento da direção da empresa. Quanto aos dados temporais, os entrevistados estão com idade entre 36 a 55 anos e com menos de 30 anos de ingresso na empresa. Ou seja, a maioria não estava na ECT quando foi criada, no período da ditadura militar, cerca de 74,4\% dos entrevistados ingressaram na empresa após 1981 . Constatamos, também, que cerca de 65,7\% nasceram entre 1961 e 1980. Demonstrando um perfil mais jovem da empresa na função de Ponto Focal.

Cerca de $25 \%$ dos empregados tem mais de 30 anos de empresa, e $31 \%$ nasceram antes de 1950 até 1960, ou seja, com mais de 55 anos de idade. O ingresso é por concurso público e pessoas com idades diferentes ingressam no serviço público a qualquer tempo.

A primeira pergunta foi a única não obrigatória no questionário e solicitava a identificação com o nome do empregado, esclarecendo que o mesmo não seria divulgado na 
pesquisa, o que foi respondido por $62 \%$ dos PF. O percentual apresentado, neste item e em outros, como veremos, nos indicam a existência de um conjunto de cerca de 30 a $40 \%$ dos empregados PF com um determinado perfil presente na empresa que identificamos como desconhecedores de temas que não estão sob sua responsabilidade.

Pergunta/Afirmativa 1 - Nome Completo

A identificação nominal era opcional, e com a informação de que não seria divulgado na pesquisa. Dos 35 respondentes, 62\% informaram seus nomes completos.

Pergunta/Afirmativa 2 - Cargo nos Correios

O Plano de Carreira dos empregados dos Correios possui três cargos: Agente de Correios (engloba Carteiro, Operador de Triagem e Transbordo, e Agente Comercial); Técnico de Correios (demais cargos que exigem ensino médio) e Analista de Correio (cargos de ensino superior). Dos que responderam ao questionário, 83\% ocupam o cargo de Analista de Correios (nível superior).

Gráfico 11 - Perfil do Ponto Focal: Cargo

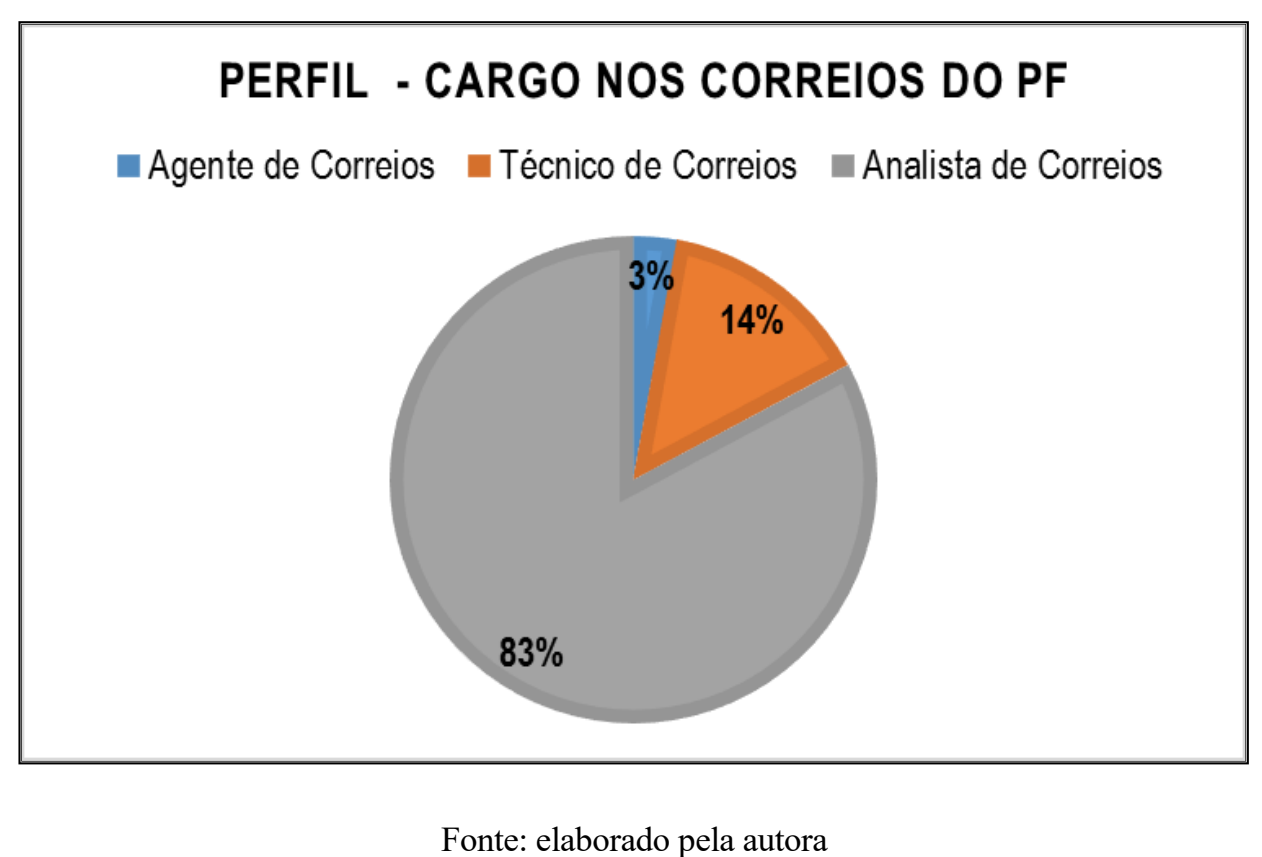

Pergunta/Afirmativa 3 - Ano de Ingresso nos Correios

Quanto ao ano de ingresso na empresa, 60,1\% ingressaram na ECT após 1991, ou seja, após o processo de redemocratização do país. Sendo que destes, 37\% a partir de 2001. 
Gráfico 12 - Perfil do Ponto Focal: Período de Ingresso

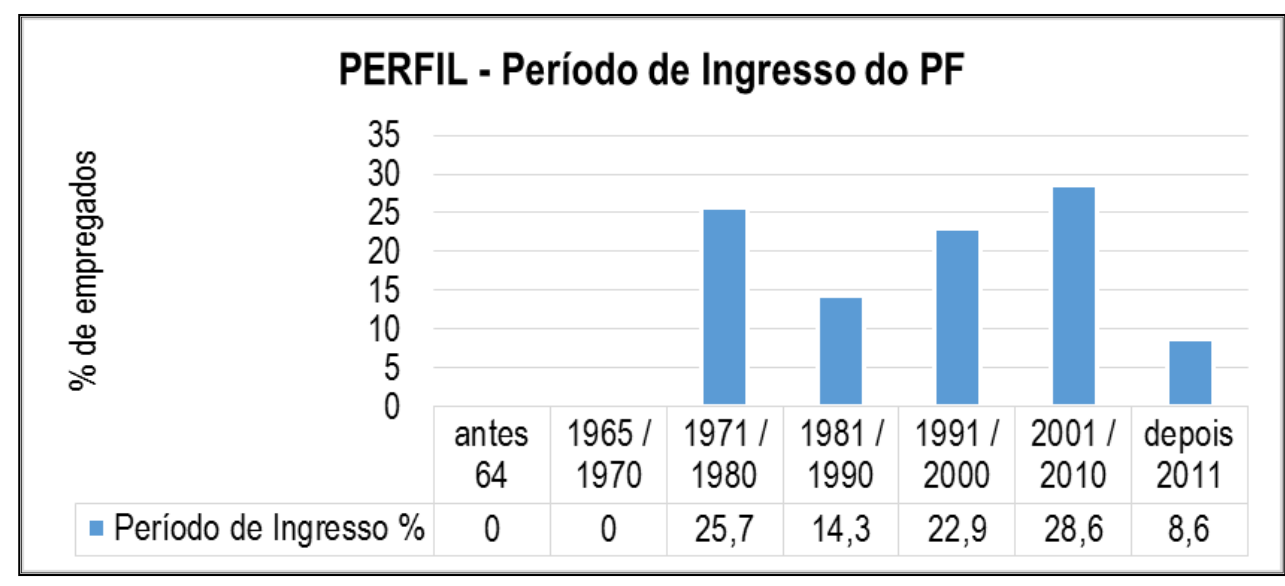

Fonte: elaborado pela autora

Pergunta/Afirmativa 4 - Função Técnica/Gerencial

Tanto na Administração Central, quanto nas Diretorias Regionais, os respondentes estão em funções estratégicas na empresa, como Analistas/Assessores, Chefe de Departamento e Gerentes, representando $85,6 \%$.

Gráfico 13 - Perfil do Ponto Focal: Função ocupada

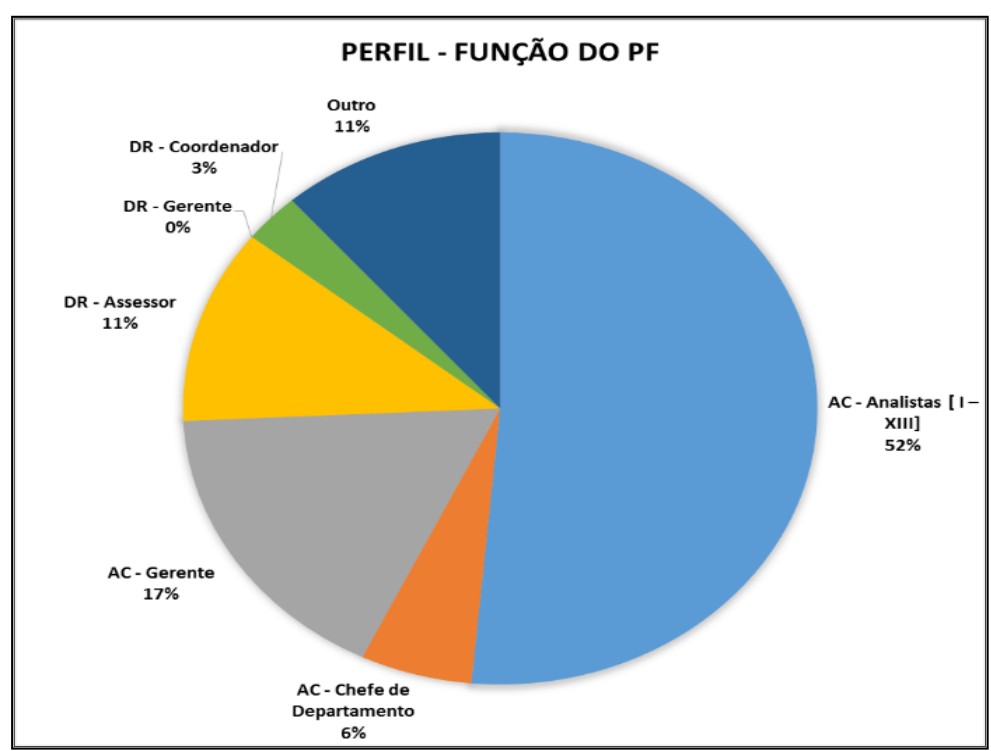

Fonte: elaborado pela autora

Pergunta/Afirmativa 5 - Formação

Todos têm nível superior, sendo $20 \%$ com Graduação; $71 \%$ com especialização e $9 \%$ com Mestrado. 
Gráfico 14 - Perfil do Ponto Focal: Formação

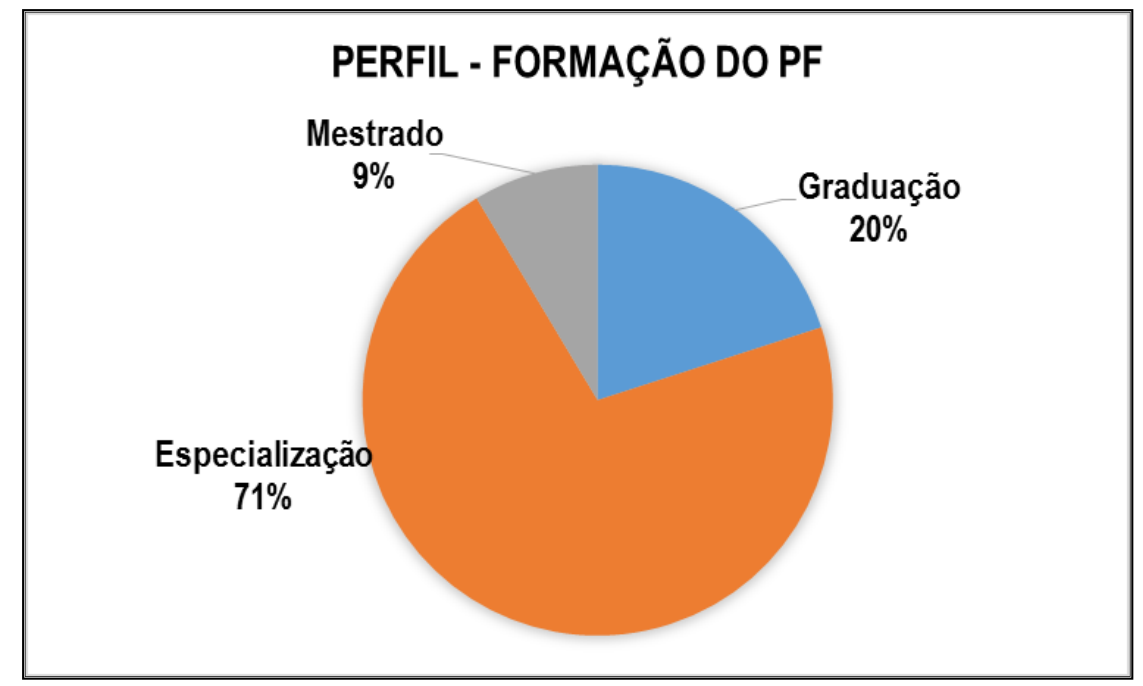

Fonte: elaborado pela autora

Pergunta/Afirmativa 6 - Ano de Nascimento

A maioria está na faixa dos 35 a 55 anos, somando $68,6 \%$ e o outro contingente, de $31,5 \%$ acima de 56 anos.

Gráfico 15 - Perfil do Ponto Focal: Ano de Nascimento

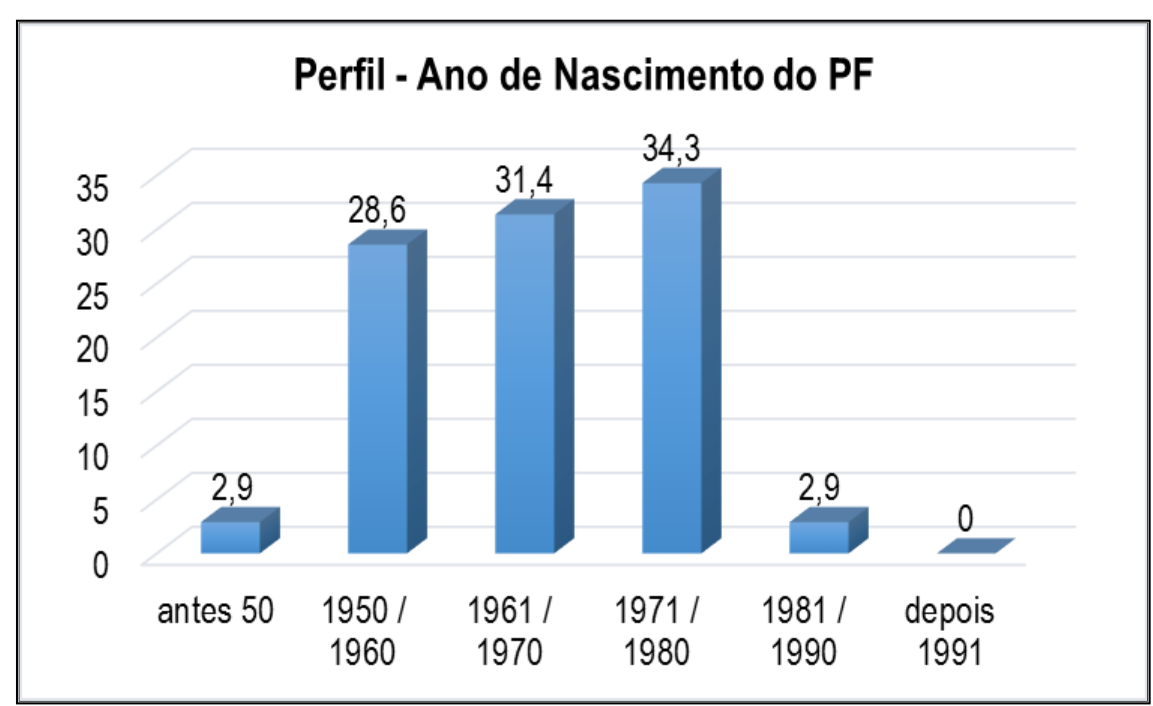

Fonte: elaborado pela autora 
Bloco 2 - Identificação da área de atuação

O bloco 2 trata da identificação da área de atuação do PF e o tempo em que atuou como elo entre o SIC e a área da empresa. Este bloco contém 5 (cinco) afirmativas que abordam a localização de atuação, área de trabalho, o período em que esteve como PF, se permanece ou não, e o ramo de atividade que desempenha.

Os dados coletados nos permitem aferir que, de forma dominante, são empregados em atuação na Administração Central em Brasília, das áreas estratégicas da empresa que envolvem administração, serviços e pessoal. A maioria está há mais de dois anos atuando como Ponto Focal, e continuava no exercício da atividade de PF quando da aplicação do questionário.

Pergunta/Afirmativa 7- Identificação do Local de atuação

O questionário foi respondido por $86 \%$ de empregados lotados na Administração Central, em Brasília e 14\% lotados nas Diretorias Regionais.

Pergunta/Afirmativa 8 - Informar a área que trabalha (a resposta era de livre manifestação)

Foram identificadas várias áreas da empresa, não estando concentrado em nenhuma área especifica, garantindo assim, um maior espectro de opiniões dos envolvidos no processo de implantação da LAI na empresa. A resposta a esta pergunta foi livre e os PFs informaram as siglas das hierarquias dos órgãos. Os dados foram organizados em função da estrutura superior da empresa.

Gráfico 16 - Perfil do Ponto Focal: Área de Lotação

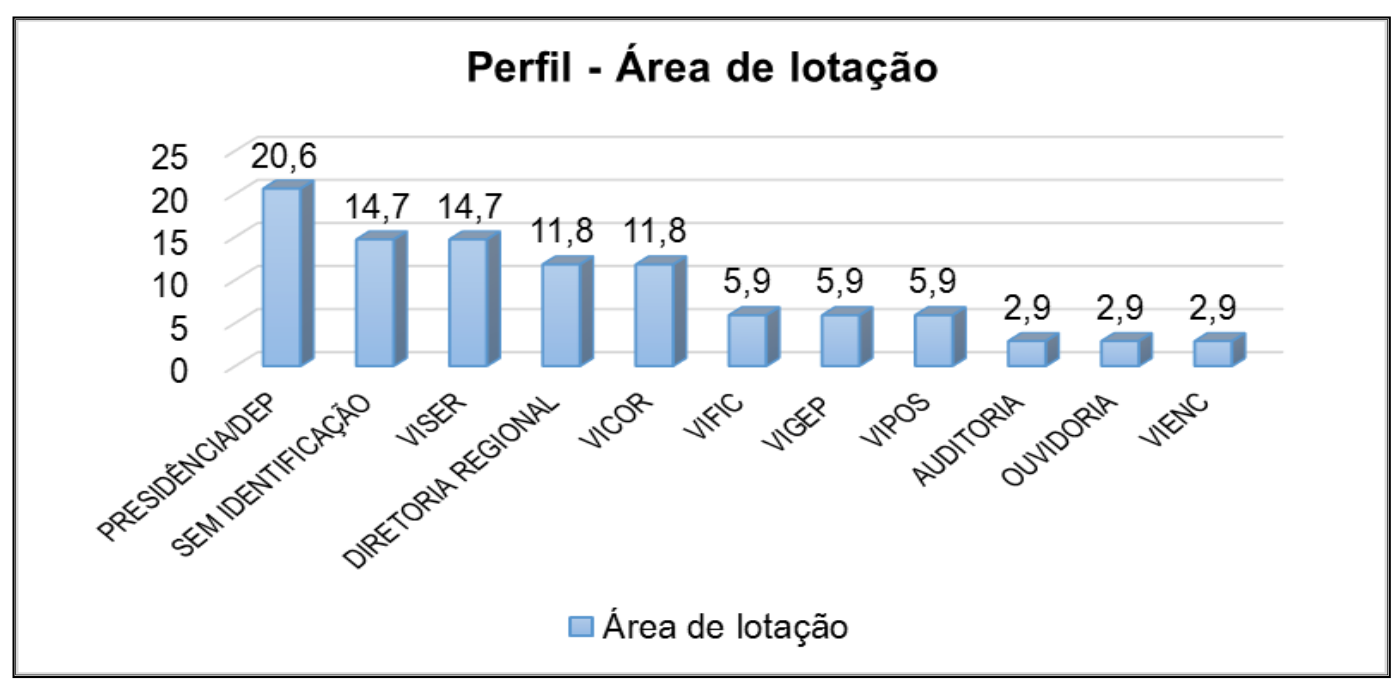

Fonte: elaborado pela autora 
Pergunta/Afirmativa 9 - Período que exerce (u) a atividade de Ponto Focal do SIC Atuam (ram) como Ponto Focal por pelo menos 2 anos, 31\%, por 3 anos, $6 \%$ e por mais de 3 anos, 29\%, totalizando $66 \%$. Portanto, a maioria esteve, e está envolvido com o SIC. Os restantes 34\%, atuaram menos de 1 ano, 26\% e marcaram como "outra" 94 , $8 \%$.

Gráfico 17 - Perfil do Ponto Focal: Período de atuação

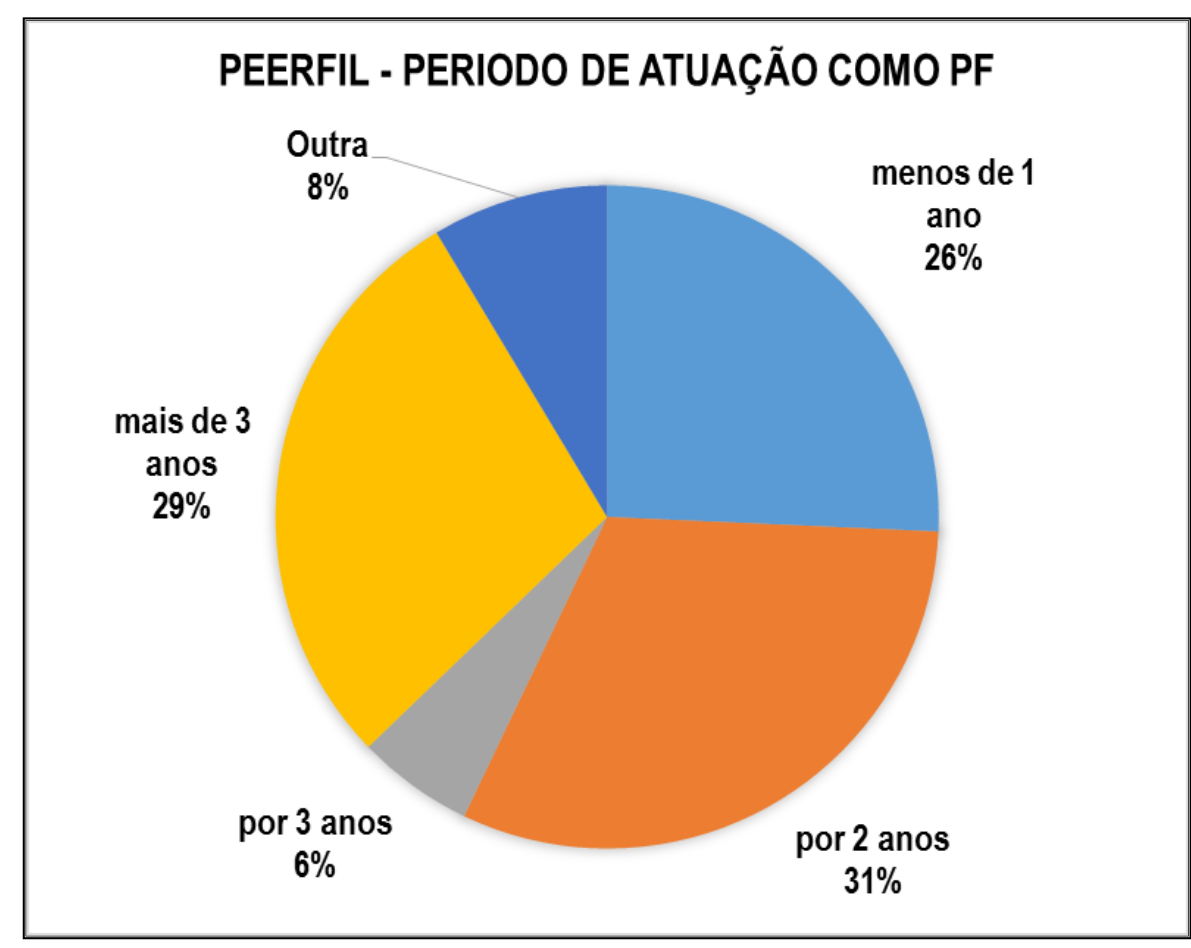

Fonte: elaborado pela autora

Pergunta/Afirmativa 10 - A atividade de Ponto Focal do SIC

Esta pergunta buscou identificar os que estavam em atuação e $77 \%$ responderam que estavam atuando com demandas do SIC no momento da entrevista.

$94 \mathrm{O}$ item "outra” foi especificado pelo respondente como gestores que responderam ao questionário. Algumas áreas o PF era o próprio chefe de departamento. 
Gráfico 18 - Perfil do Ponto Focal: Atividade no SIC

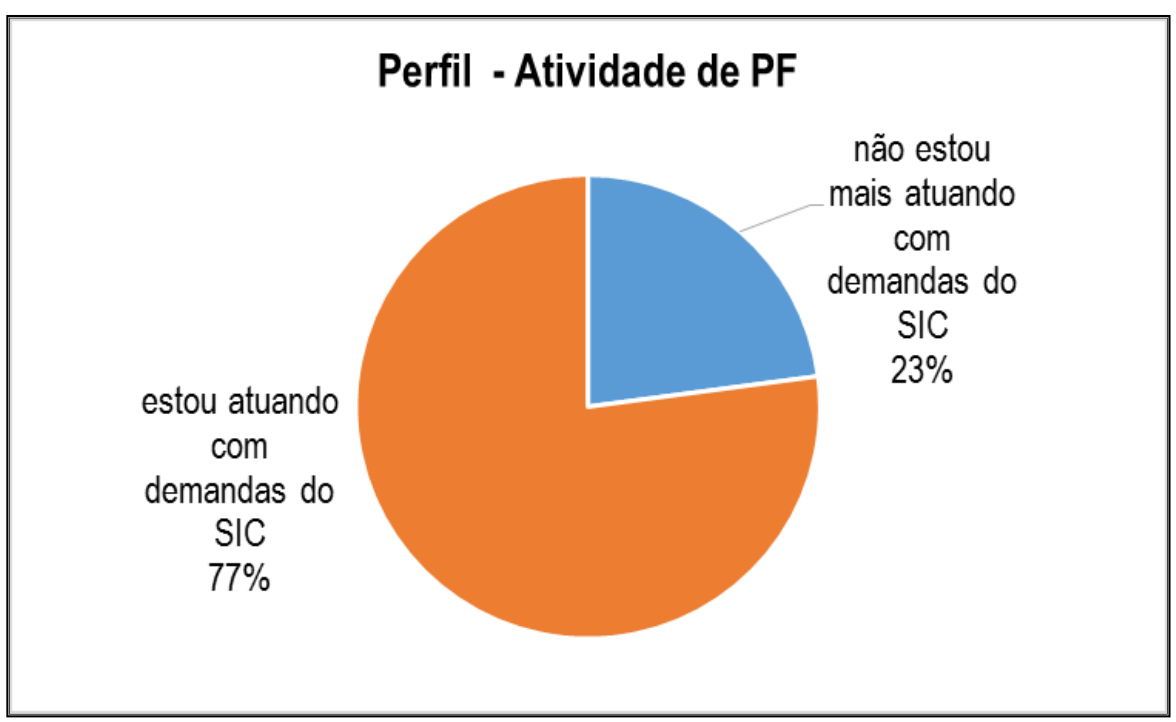

Fonte: elaborado pela autora

Pergunta/Afirmativa 11 - Ramo de Atividade que atua

Foram listadas todas as áreas de atuação da empresa, sendo que $25,7 \%$ dos respondentes são da área de Administração e Serviços; $14,3 \%$ da área de Comunicação e Sustentabilidade; 11,4\% da área de Gestão de Pessoas, totalizando 51,4\% dos respondentes. Os demais estão distribuídos em outras 11 áreas e DRs.

Gráfico 19 - Perfil do Ponto Focal: Ramo de atividade do PF

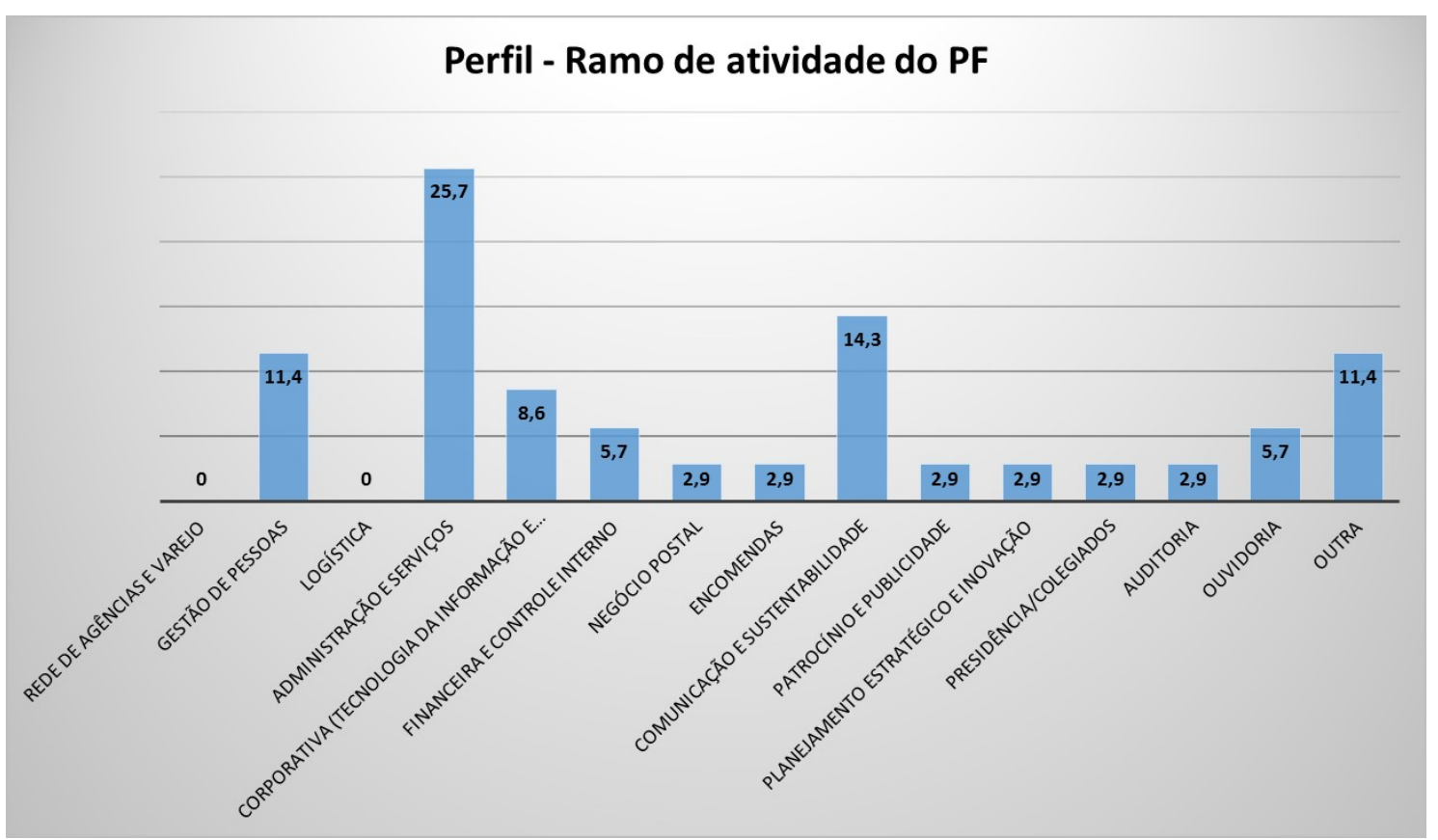

Fonte: elaborado pela autora 
Bloco 3 - Requisitos de Qualidade da Organização da Informação

O bloco 3 trata dos requisitos de qualidade da Organização da Informação e apresenta 16 (dezesseis) afirmativas envolvendo a análise com relação ao tempo, ao conteúdo, à forma e a localização da informação conforme as tabelas a seguir.

$\mathrm{Na}$ Tabela 7, nas afirmativas 12 a 14, solicitamos a análise dos Pontos Focais quanto ao tempo de disponibilização da informação, uma vez que o número de prorrogação do prazo para a resposta apresentar um índice alto em comparação com os demais órgãos da administração pública federal. A informação poderia não estar disponibilizada quando solicitada pelo cidadão. Entretanto, a maioria dos entrevistados informam que a informação está sempre disponibilizada e está disponibilizada quando recebe o pedido, assim como atualizada (cerca de 60\%). Veremos na resposta à pergunta 21 , uma certa contradição com estas respostas.

Tabela 7 - Percepção dos PF: Tempo de disponibilização da informação

\begin{tabular}{|c|c|c|c|c|c|c|}
\hline Análise com relação ao tempo & DC & DP & NDNC & $\mathrm{CP}$ & $\mathrm{CC}$ & D \\
\hline $\begin{array}{l}12 \text { A informação solicitada está disponibilizada quando } \\
\text { recebo o pedido de informação }\end{array}$ & 14,3 & 20,0 & 8,6 & 48,6 & 8,6 & 0,0 \\
\hline $\begin{array}{l}13 \text { A informação solicitada está atualizada quando recebo o } \\
\text { pedido de informação }\end{array}$ & 8,6 & 20,0 & 11,4 & 45,7 & 14,3 & 0,0 \\
\hline $\begin{array}{l}14 \text { A informação solicitada está disponibilizada sempre que é } \\
\text { requerida }\end{array}$ & 11,4 & 14,3 & 14,3 & 40,0 & 20,0 & 0,0 \\
\hline
\end{tabular}

Fonte: elaborado pela autora

Na Tabela 8, nas afirmativas 15 a 17, solicitamos a análise acerca do conteúdo das informações. A maioria considera que a informação não contém erros e está em conformidade com as necessidades dos cidadãos, sendo que a maioria absoluta considera possível ela ser organizada de modo específico ou geral, dependendo da demanda dos cidadãos. Entretanto, quanto à afirmativa de que toda a informação necessária está disponibilizada apresentou uma divisão entre o grupo, com uma leve maioria para os que concordam $(51,4 \%)$. 
Tabela 8 - Percepção dos PF: Conteúdo da informação

$\begin{aligned} & \text { Análise com relação ao conteúdo } \\ & 15 \text { A informação solicitada não contém erros e está em }\end{aligned}$ DC
$\begin{aligned} & \text { conformidade com as necessidades de informação dos } \\ & \text { cidadãos; }\end{aligned}$
$\begin{aligned} & 16 \\ & \text { Toda a informação necessária está disponibilizada }\end{aligned}$

Fonte: elaborado pela autora

$\mathrm{Na}$ Tabela 9, nas afirmativas 18 a 21, as afirmativas tratam da forma em que está disponibilizada a informação e a maioria de 50 a 70\% dos Pontos Focais considera que a mesma está disponibilizada de uma forma clara e de fácil compreensão, na íntegra ou sintetizada e em formato que atende os requisitos de acesso dos cidadãos. Entretanto, 80\% dos PF concordam que a informação está dispersa, em diferentes espécies documentais e é necessário produzir um novo documento, ou sistematizá-la, para disponibilizar a informação demandada. Se a informação está dispersa, como ela está disponibilizada sempre que é requerida (pergunta 14)? Aqui se revela uma contradição identificada na pesquisa.

Tabela 9 - Percepção dos PF: Forma em que está disponibilizada a informação

\begin{tabular}{|c|c|c|c|c|c|c|}
\hline Análise com relação à forma & DC & DP & NDNC & $\mathrm{CP}$ & CC & D \\
\hline $\begin{array}{l}18 \text { A informação solicitada está disponibilizada de uma forma } \\
\text { clara e de fácil compreensão }\end{array}$ & 0,0 & 25,7 & 2,9 & 48,6 & 20,0 & 2,9 \\
\hline $\begin{array}{l}19 \text { A informação solicitada está disponibilizada na íntegra ou } \\
\text { sintetizada, conforme a demanda dos cidadãos }\end{array}$ & 2,9 & 31,4 & 0,0 & 48,6 & 11,4 & 5,7 \\
\hline $\begin{array}{l}20 \text { A informação está disponibilizada em um formato que a } \\
\text { torna inteligível e está de acordo com os requisitos de } \\
\text { acesso dos cidadãos. }\end{array}$ & 0,0 & 28,6 & 20,0 & 34,3 & 17,1 & 0,0 \\
\hline $\begin{array}{l}21 \text { A informação está dispersa em diferentes espécies e é } \\
\text { necessário produzir um novo documento, ou sistematizá- } \\
\text { las, para disponibilizar a informação demandada. }\end{array}$ & 2,9 & 11,4 & 2,9 & 57,1 & 22,9 & 2,9 \\
\hline
\end{tabular}

Fonte: elaborado pela autora

Na Tabela 10, nas afirmativas 22 a 27, apresentamos a percepção dos PFs quanto a localização da informação quando introduzimos os termos arquivísticos de "arquivos corrente, 
intermediário e permanente". A maioria absoluta informa que a maior parte da informação solicitada está no arquivo corrente $(68,5 \%)$, mas discordam que esteja no arquivo intermediário. Percebemos que a marcação das respostas de desconhecimento e que nem concordam e nem discordam, possa refletir a falta de informação sobre os prazos de prescrição dos próprios documentos. Já quando perguntamos sobre informações no arquivo permanente ${ }^{95}$ as opiniões ficaram divididas, quase igualmente, entre os que discordam, concordam e nem discordam, nem concordam. Para muitos ainda persiste a proibição de eliminação de documentos determinada no TAC, pelo MPF. Assim, independentemente da localização da informação, esta não poderia ser eliminada. Outra pergunta que dividiu os PF foi a localização das informações na memória oral de empregados antigos, cerca de 45,8\% discordam da afirmativa, mas $40 \%$ concordam, o que corrobora com a situação que levantamos quanto ao período sem uma política de gestão documental e que constantemente nos remetia a buscar antigos empregados para recuperar parte do processo de decisão no passado (informação pessoal).

Quanto à localização das informações em sistemas eletrônicos para produzir a resposta, é dominante $(71,5 \%)$ a posição que concorda que os consulta para produzir a resposta solicitada pelo cidadão. Ao buscarmos confirmação sobre o descarte de informações antes de 2011, percebemos que $31 \%$ desconhece o assunto, que parece se justificar pelo contingente mais jovem na empresa, verificado no perfil dos Pontos Focais. Há uma nítida divisão entre os que concordam e os que discordam, e os que nem concordam, nem discordam. Esta divisão corrobora com a nossa percepção de que de fato há informações que não foram arquivadas e foram eliminadas anteriormente sem o devido tratamento.

\footnotetext{
${ }^{95} \mathrm{Na}$ pergunta 24 usamos o termo arquivo permanente, usual entre os profissionais da ciência da informação, mas não do conjunto dos empregados da ECT. Na empresa o arquivo permanente está nos Arquivos Gerais. Esse pode ser um dos motivos da dispersão nas respostas.
} 
Tabela 10 - Percepção dos PF: Localização da informação

\begin{tabular}{|c|c|c|c|c|c|c|}
\hline $\begin{array}{c}\text { Análise com relação a localização da } \\
\text { informação }\end{array}$ & $D C$ & $\mathrm{DP}$ & NDNC & $\mathrm{CP}$ & $\mathrm{CC}$ & D \\
\hline $\begin{array}{l}22 \text { A maior parte da informação solicitada está no arquivo } \\
\text { corrente (documentos vigentes, em uso). }\end{array}$ & 2,9 & 17,1 & 8,6 & 51,4 & 17,1 & 2,9 \\
\hline $\begin{array}{l}23 \text { A maior parte da informação solicitada está no arquivo } \\
\text { intermediário (final de vigência, aguardam prazos de } \\
\text { prescrição e destinação final). }\end{array}$ & 11,4 & 17,1 & 20,0 & 31,4 & 0,0 & 20,0 \\
\hline $\begin{array}{l}24 \text { A maior parte da informação solicitada está no arquivo } \\
\text { permanente (sem vigência, mas providos de valor, não } \\
\text { podem ser eliminados) }\end{array}$ & 11,4 & 22,9 & 25,7 & 22,9 & 11,4 & 5,7 \\
\hline $\begin{array}{l}25 \text { Algumas informações solicitadas não estão em arquivos, } \\
\text { mas na memória oral de empregados antigos na empresa. }\end{array}$ & 22,9 & 22,9 & 2,9 & 31,4 & 8,6 & 11,4 \\
\hline $\begin{array}{l}26 \text { Algumas informações solicitadas estão em sistemas } \\
\text { eletrônicos que são consultados para produzir a resposta, } \\
\text { sem a emissão de relatórios físicos. }\end{array}$ & 2,9 & 20,0 & 2,9 & 42,9 & 28,6 & 2,9 \\
\hline $\begin{array}{l}27 \text { Algumas informações solicitadas não estão arquivadas e } \\
\text { foram eliminadas por políticas de qualidade total antes de } \\
2011 \text {. }\end{array}$ & 11,4 & 17,1 & 17,1 & 20,0 & 2,9 & 31,4 \\
\hline
\end{tabular}

Fonte: elaborado pela autora

Bloco 4 - Requisitos de Gestão, Segurança e Transparência da Informação

Nesse bloco abordaremos a gestão de documentos, segurança e transparência. As afirmativas 28 a 35, na Tabela 11, tratam da mudança da sistemática de gestão documental na empresa e desejamos ter a percepção dos Pontos Focais sobre sua importância na atividade do SIC.

A maioria considera que facilitou a recuperação dos documentos $(60 \%)$ e que o Núcleo de Documentação e Arquivo (NDA) é um aliado importante na localização dos documentos e processos $(68,5 \%)$. Quanto às dificuldades de consulta de documentos como imagem no NDA, a maioria mostrou desconhecimento ou indiferença, o que pode caracterizar a não utilização constante do NDA, já que este último digitaliza apenas processos de contratação e ficha cadastral dos empregados. Entretanto, há a concordância de 40\% dos Pontos Focais com a essa afirmativa e, havendo no perfil dos respondentes a este questionário a presença da área administrativa e de pessoal, podemos inferir que é um problema a digitalização como imagem dos documentos. 
O sistema GDC foi considerado importante na localização dos processos da empresa com expressiva maioria concordando com a afirmativa $(88,6 \%)$ e não tendo nenhuma discordância, foi o único item do questionário em que não houve nenhuma manifestação de discordância, confirmando a contribuição do sistema na gestão da empresa. Assim como, para a maioria $(77,2 \%)$ há grande dificuldade em localizar documentos de dez anos.

Quanto a análise sobre a classificação de assuntos nos documentos criados no GDC, as afirmativas 33 e 34 tratam do preenchimento dos dados no GDC. No que se refere a informação do assunto, quando se cria um documento, a maioria concorda que é informado corretamente (60\%), e quando perguntado se o código de classificação do assunto está identificado percebemos uma pequena redução dos que concordam (51,5\%). Com relação à política de preservação e eliminação de documentos (pergunta 35 ) a maioria $(71,4 \%)$ confirma que conhece a atual política da empresa.

Tabela 11 - Percepção dos PF: Gestão documental

\begin{tabular}{|c|c|c|c|c|c|c|}
\hline $\begin{array}{c}\text { Análise com relação à gestão } \\
\text { documental }\end{array}$ & DC & DP & NDNC & $\mathrm{CP}$ & CC & D \\
\hline $\begin{array}{l}28 \text { A mudança de sistemática de gestão documental a } \\
\text { partir de } 2011 \text { (NUP, GDC, Protocolo) facilitou a } \\
\text { recuperação dos documentos. }\end{array}$ & 0,0 & 11,4 & 17,1 & 34,3 & 25,7 & 11,4 \\
\hline $\begin{array}{l}29 \text { O NDA (Núcleo de Documentação e Arquivo) é um } \\
\text { aliado importante na localização dos documentos e } \\
\text { processos. }\end{array}$ & 0,0 & 2,9 & 8,6 & 37,1 & 31,4 & 20,0 \\
\hline $\begin{array}{l}30 \text { Tenho dificuldade em localizar documentos pelo NDA } \\
\text { uma vez que a digitalização como imagem não me } \\
\text { permite uma busca individualizada de documentos. }\end{array}$ & 2,9 & 5,7 & 22,9 & 37,1 & 2,9 & 28,6 \\
\hline $\begin{array}{l}31 \text { O GDC (Gestão de Documentos Correntes) é um } \\
\text { sistema que contribui na localização dos processos na } \\
\text { empresa. }\end{array}$ & 0,0 & 0,0 & 8,6 & 48,6 & 40,0 & 2,9 \\
\hline $\begin{array}{l}32 \text { Há dificuldades em localizar documentos com origem } \\
\text { anterior à 10(dez) anos atrás. }\end{array}$ & 0,0 & 2,9 & 11,4 & 48,6 & 28,6 & 8,6 \\
\hline
\end{tabular}


Continuação

$\begin{aligned} & \text { Análise com relação à gestão } \\ & \text { documental }\end{aligned}$
$\begin{aligned} & 33 \text { Na abertura de NUPs, e/ou criação de qualquer } \\ & \text { documento o assunto é informado corretamente o que }\end{aligned}$
$\begin{aligned} & \text { possibilita localizar processos de assuntos } \\ & \text { relacionados. }\end{aligned}$

Fonte: elaborado pela autora

Na Tabela 12 constam as afirmativas 36 a 41, que tratam das mudanças ocorridas na área de trabalho do PF em função da implantação da Lei de Acesso à Informação.

A afirmativa 36 trata da implantação de uma gestão da informação na área e a resposta dividiu os participantes, 42,8\% confirmaram a existência de uma política e 37,2\% discordaram, o que sinaliza que nem todas as áreas da empresa foram afetadas com a LAI.

$\mathrm{Na}$ afirmativa $37,57,1 \%$ concordam com a existência de procedimentos de proteção e controle de informações sigilosas ou de acesso restrito; 11,4\% desconhecem se há procedimentos; $22,9 \%$ discordam e $8,6 \%$ nem concordam, nem discordam.

$\mathrm{Na}$ afirmativa 38, 65,7\% concordam que houve modificação no entendimento acerca de informações que antes eram consideradas sigilosas e a partir da LAI passaram a ser ostensivas; apenas 11,4\% discordaram; 14,3\% nem concordaram, nem discordaram e 8,6\% desconhecem. Esta afirmativa foi a que um maior número de PF concordou na análise das mudanças em sua área trazidas pela LAI.

Entretanto, na afirmativa 39, quanto à atualização dos manuais, das normas da área em função da LAI, 45,7\% concordam que houve mudanças, 30\% discordam, 20\% desconhecem, se houve atualizações e 14,3\% nem concordam, nem discordam. Essa resposta, aponta para o fato de que algumas áreas não normatizaram o tratamento das informações por elas produzidas e a decisão de acesso ou restrição é do gestor, no momento de atender o pedido.

$\mathrm{Na}$ afirmativa 40 inserimos as orientações já aprovadas na empresa e constante do Manual de Tecnologia da Informação e Comunicação (MANTIC) que determina procedimentos para tratamento e transporte de documentos classificados como de acesso 
restrito e/ou sigilosos e 42,9\% desconhecem o assunto; concordaram que a área definiu procedimentos $25,7 \%$; discordam da afirmativa $20 \%$ e nem concordam e nem discordam 11 , 4\%. Este é um ponto importante, uma vez que a empresa adequou as normas à legislação vigente, mas as respostas à essa afirmativa indicam um desconhecimento dos empregados para o cumprimento das mesmas.

A afirmativa 41 aborda o conhecimento do PF sobre a existência de uma política de Gestão de Conhecimento (GC) na área, 48,5\% responderam concordando que a área em que trabalham tem uma política de GC com a afirmativa; discordam 34,3\%; nem concordam e nem discordam 2,9\% e desconhecem 14,3\%. Uma questão bem preocupante quando mais um Programa de Demissão Imotivada (PDI) está sendo implementado na empresa.

Tabela 12 - Percepção dos PF: Mudanças trazidas com a LAI

\begin{tabular}{|c|c|c|c|c|c|c|}
\hline Mudanças com a LAl & DC & DP & NDNC & $\mathrm{CP}$ & $\mathrm{CC}$ & D \\
\hline $\begin{array}{l}36 \text { A área, como decorrência da LAl, implementou política } \\
\text { de gestão de informação. }\end{array}$ & 14,3 & 22,9 & 17,1 & 31,4 & 11,4 & 2,9 \\
\hline $\begin{array}{l}37 \text { A área determinou procedimentos documentados de } \\
\text { Proteção e Controle de Informações Sigilosas/Acesso } \\
\text { Restrito. }\end{array}$ & 8,6 & 14,3 & 8,6 & 31,4 & 25,7 & 11,4 \\
\hline $\begin{array}{l}38 \text { Houve modificação no entendimento da área acerca } \\
\text { de informações que antes eram consideradas } \\
\text { sigilosas e, a partir da LAl, passaram a ser públicas. }\end{array}$ & 2,8 & 8,6 & 14,3 & 28,6 & 37,1 & 8,6 \\
\hline $\begin{array}{l}39 \text { Houve atualização nos manuais da área (normas e } \\
\text { procedimentos) em função da LAl. }\end{array}$ & 14,3 & 5,7 & 14,3 & 31,4 & 14,3 & 20,0 \\
\hline $\begin{array}{l}40 \text { A área definiu procedimentos internos para o } \\
\text { tratamento e transporte de documentos classificados } \\
\text { como de Acesso Restrito e/ou Sigilosos que em } \\
\text { suporte digital deverá ser transmitida por meio da } \\
\text { Internet ou da Rede Corporativa dos Correios, } \\
\text { utilizando Virtual Private Network (VPN), criptografia ou } \\
\text { certificação digital (MANTIC 5/8-Anexo } 2-5.9 \text { ). }\end{array}$ & 5,7 & 14,3 & 11,4 & 17,1 & 8,6 & 42,9 \\
\hline${ }^{41}$ A área tem política de Gestão do Conhecimento & 20,0 & 14,3 & 2,9 & 37,1 & 11,4 & 14,3 \\
\hline
\end{tabular}

Fonte: elaborado pela autora

$\mathrm{Na}$ Tabela 13, constam as respostas às afirmativas 42 a 45, que tratam da Política de Transparência Pública na empresa. A afirmativa 42 aborda a criação de uma rotina para identificação de informações de amplo interesse público para a publicação em transparência ativa: $40 \%$ concordaram que área tenha se preocupado com o tema; $22,8 \%$ desconhecem qualquer iniciativa; $8,6 \%$ nem concordam e nem discordam e $28,6 \%$ discordam. 
Da mesma forma, na afirmativa 43, percebe-se que a maioria das áreas da empresa não tomou como base os pedidos de informação já recebidos para melhorar as informações na internet, uma vez que apenas $45,7 \%$ concordaram com a afirmativa. A resposta à essa afirmativa apresenta um aspecto preocupante, ao identificar que 22,8\% dos Pontos Focais desconhecem o assunto, ou a iniciativa, quando eles, como PF, deveriam estar identificando esses assuntos, através das demandas recebidas pelo SIC.

Com relação à afirmativa 44, que trata da atualização das informações da área na página dos Correios, 54,3\% confirmam que há essa rotina. A Gerência do SIC responsável pela página da LAI na internet, executava uma rotina de cobrança das áreas, existindo uma matriz de responsabilidade para cada assunto da página ${ }^{96}$. Entretanto, $17,1 \%$ desconhecem a existência de uma rotina; $22,9 \%$ discordam e 2,9\% nem discordam e nem concordam.

Por fim, na afirmativa 45, buscamos saber se a área promoveu a sensibilização dos servidores quanto aos seus deveres frente ao direito de acesso à informação do cidadão. Para $60 \%$ dos PF a área promoveu a sensibilização; 31,4\% discordaram; 5,7\% desconhecem e 2,9\% nem concordaram, nem discordaram.

Tabela 13 - Percepção dos PF: Política de Transparência Pública na área que trabalha

\begin{tabular}{|c|c|c|c|c|c|c|}
\hline Política de Transparência Pública & DC & $\mathrm{DP}$ & NDNC & $\mathrm{CP}$ & CC & D \\
\hline $\begin{array}{l}42 \text { A área criou uma rotina para identificação de } \\
\text { informações de amplo interesse público para a } \\
\text { publicação em transparência ativa }\end{array}$ & 14,3 & 14,3 & 8,6 & 34,3 & 5,7 & 22,8 \\
\hline $\begin{array}{l}43 \text { A área tomou por base os pedidos mais } \\
\text { recorrentes/frequentes para incrementar a Seção de } \\
\text { Acesso à Informação no sítio dos Correios }\end{array}$ & 8,6 & 8,6 & 14,3 & 37,1 & 8,6 & 22,8 \\
\hline $\begin{array}{l}44 \text { A área possui rotina de atualização de suas } \\
\text { informações na Seção de Acesso à Informação no } \\
\text { sítio dos Correios. }\end{array}$ & 2,9 & 20,0 & 5,7 & 42,9 & 11,4 & 17,1 \\
\hline $\begin{array}{l}45 \text { A área promoveu a sensibilização dos servidores em } \\
\text { exercício quanto aos seus deveres frente ao direito de } \\
\text { acesso à informação do cidadão. }\end{array}$ & 8,6 & 22,8 & 2,9 & 40,0 & 20,0 & 5,7 \\
\hline \multicolumn{7}{|c|}{$\begin{array}{l}\text { DC - Discordo completamente; DP - Discordo parcialmente; NDNC - Nem discordo, nem concordo; CP - Concordo parcialmente; CC - Concordo } \\
\text { completamente; D - Desconheço }\end{array}$} \\
\hline
\end{tabular}

Fonte: elaborado pela autora

\footnotetext{
${ }^{96}$ Esta é uma informação pessoal, pela atuação da autora como gerente do SIC, de maio de 2012 à maio de 2016.
} 
Bloco 5 - Requisitos de Disponibilização da Informação

Na Tabela 14, constam as afirmativas 46 a 50, em que buscamos a percepção dos Pontos Focais sobre a empresa e a disponibilização da informação, com perguntas que envolvem o caráter público e empresarial da empresa, para verificar o comportamento dos Pontos Focais sobre o tema.

A afirmativa 46 solicita dos PF o posicionamento quanto aos Correios, por ser uma empresa pública, ter transparência nas suas informações. Concordaram com esta afirmativa 94,3\% dos entrevistados, e apenas 5,7\% discordaram parcialmente. Foi a única pergunta do questionário aplicado em que o Concordo Plenamente e Parcialmente teve maior escolha entre os PF, nenhum desconhecimento, discordância completa e nem concorda e nem discorda.

$\mathrm{Na}$ afirmativa 47, inserirmos o fato de atuar no ambiente concorrencial e defender a existência de restrição para alguns gestores, mesmo sendo pública, e 88,5\% concordam com a restrição e apenas $11,5 \%$ discordam da afirmativa.

A afirmativa 48, nos permite identificar mais claramente os conflitos da situação híbrida da empresa na resposta dos Pontos Focais, ao afirmar que "é uma empresa pública de direito privado que atua no mercado competitivo e não pode ter suas informações públicas", em que discordaram $54,2 \%$ da afirmativa e concordaram $42,9 \%$.

$\mathrm{Na}$ afirmativa 49 inserimos as obrigações em função do monopólio postal previsto na $\mathrm{CF}$, para justificar o acesso de todas as informações da empresa, concordaram $60 \%$ dos entrevistados e os demais $37,2 \%$ discordaram e 2,8\% nem concordaram, nem discordaram.

E por fim, na afirmativa 50 que apresenta a defesa de uma completa autonomia e independência da empresa para decidir o que deve ou não ser disponibilizado percebemos, mais uma vez, os conflitos com a condição híbrida da empresa. Para 54,2\% dos entrevistados a empresa deveria ter autonomia; 37,1\% discordam e 8,6\% nem concordam, nem discordam. 
Tabela 14 - Percepção dos PF: Disponibilização da informação

\begin{tabular}{|c|c|c|c|c|c|c|}
\hline Disponibilização da informação & DC & DP & NDNC & $\mathrm{CP}$ & CC & D \\
\hline $\begin{array}{l}46 \text { Os Correios são empresa pública e por isso deve ter } \\
\text { transparência nas suas informações. }\end{array}$ & 0,0 & 5,7 & 0,0 & 31,4 & 62,9 & 0,0 \\
\hline $\begin{array}{l}47 \text { Os Correios, em que pese ser uma empresa pública, } \\
\text { atua no âmbito concorrencial e essas informações } \\
\text { devem ser restrita à alguns gestores. }\end{array}$ & 2,9 & 8,6 & 0,0 & 37,1 & 51,4 & 0,0 \\
\hline $\begin{array}{l}48 \text { Uma empresa pública de direito privado, que atua no } \\
\text { mercado competitivo, não pode ter suas informações } \\
\text { públicas. }\end{array}$ & 11,4 & 42,8 & 2,9 & 40,0 & 2,9 & 0,0 \\
\hline $\begin{array}{l}49 \text { monopólio postal previsto na Constituição determina } \\
\text { o compromisso público com a sociedade brasileira que } \\
\text { deve ter acesso a todas as informações da empresa. }\end{array}$ & 8,6 & 28,6 & 2,8 & 45,7 & 14,3 & 0,0 \\
\hline $\begin{array}{l}50 \text { Os Correios deveriam ter autonomia e independência } \\
\text { de qualquer órgão e decidir o que deve ou não ser } \\
\text { disponibilizado. }\end{array}$ & 11,4 & 25,7 & 8,6 & 37,2 & 17,1 & 0,0 \\
\hline
\end{tabular}

Fonte: elaborado pela autora

Os 94,3\% dos entrevistados, empregados da empresa, que concordam que como empresa pública deve ter transparência (afirmativa 46) é reduzido a 54,2\% quando se trata de disponibilizar as informações, defendendo a restrição e a autonomia e independência.

\subsection{Relatório de Avaliação da Integridade da ECT}

Dentre as ações listadas de transparência pública adotadas na última década, listamos também a Lei 12.846/2013, conhecida como a Lei Anticorrupção. O Decreto 8.420/2015, que regulamenta a referida lei, definiu a obrigatoriedade de elaboração de um Programa de Integridade para cada pessoa jurídica que consiste "no conjunto de mecanismos e procedimentos internos de integridade, auditoria e incentivo à denúncia de irregularidade e na aplicação efetiva de códigos de ética e de conduta, políticas e diretrizes com objetivo de detectar e sanar desvios, fraudes, irregularidades e atos ilícitos praticados contra a administração pública, nacional ou estrangeira" 
Por meio da avaliação de integridade, a CGU busca conhecer o estágio evolutivo em que se encontram as empresas estatais em termos de políticas e procedimentos relacionados à ética e integridade. O objetivo da avaliação, segundo a CGU, é promover o seu aprimoramento, com a finalidade de diminuir o risco de corrupção e fraudes, bem como aumentar a capacidade de detecção e remediação das irregularidades que venham a ocorrer. $\mathrm{Na}$ avaliação foram tomados como referência os parâmetros elencados no artigo 42, do Decreto $n^{\circ} 8.420 / 2015$. A ECT foi avaliada no ano de 2015, "Relatório de Avaliação da Integridade em Empresas Estatais $n^{\circ}$ 201503942” (BRASIL/CGU, 2015). Neste relatório foram analisados quinze itens, agrupados em cinco dimensões:

1 Desenvolvimento do Ambiente de Gestão do Programa de Integridade;

1 Análise Periódica de Riscos;

2 Estruturação e Implantação das Políticas e Procedimentos;

3 Comunicação e Treinamento; e

4 Monitoramento do Programa, medidas de remediação e aplicação de penalidades.

A dimensão "Comunicação e Treinamento" trata dos aspectos relativos aos seguintes itens:

I - Treinamentos periódicos e comunicação sobre o programa de integridade; e

II - Transparência da pessoa jurídica.

A CGU apresenta suas "Conclusões e sugestões de melhoria" nos aspectos de transparência da ECT, onde reforça a necessidade de adotar uma linguagem amigável para com o cidadão.

Transparência da pessoa jurídica

Em relação à transparência passiva, verificou-se haver um Serviço de Informações ao Cidadão (SIC) instalado no Térreo do Edifício-sede em Brasília/DF. O setor dispõe dos equipamentos básicos necessários ao tipo de serviço executado (computadores, impressora, linhas telefônicas, aparelho de fax e aparelho de digitalização), mas não dispõe de sistema interno de tramitação de processos, não sendo possível ao cidadão acompanhar sua tramitação. O tamanho e perfil da equipe do SIC estão razoavelmente adequados à demanda atual, tanto para o atendimento via e-SIC quanto para o atendimento presencial. No que se refere à Transparência Ativa, a empresa divulga em sua página na internet os contratos em que figura como contratante, embora o caminho a ser desenvolvido para se obter tais informações não seja o mais adequado em razão da nomenclatura utilizada. Divulgam também informações sobre a estrutura de decisão da empresa, atas de reuniões, vinculações hierárquicas e competências dos principais órgãos colegiados, mas a divulgação dos principais acionistas, embora esteja disponível, é feita de modo indireto. Foi sugerido à empresa adotar linguagem 
amigável ao cidadão para as informações divulgadas no seu portal da internet, especialmente no que se refere aos contratos firmados, de forma a trazer mais clareza para os cidadãos que buscam informações da empresa (Ibid, p.13/14, grifo da autora)

Na análise dos resultados item a item, há o relato dos técnicos da CGU sobre a aplicação de um questionário dirigido aos empregados que realizaram cursos sobre o programa de integridade e que nenhum respondeu ao questionário.

Cumpre ressaltar que para a verificação do item 4 - Treinamentos periódicos e comunicação sobre o programa de integridade - foi realizada aplicação de outro questionário específico. Foi realizado o mesmo processo de seleção aleatório no universo dos empregados que possuíam e-mail funcional cadastrado na base de dados da ECT, mas considerando somente aqueles que tiveram treinamento sobre o tema nos últimos dois anos, conforme indicação da ECT. O processo culminou na seleção de 50 colaboradores que receberam um convite da CGU por e-mail para responder ao questionário. No entanto, não houve a resposta de nenhum empregado selecionado, o que, além de impedir a realização de inferências, não permitiu qualquer avaliação sobre a percepção dos empregados no que se refere aos treinamentos e comunicação sobre o tema de integridade no âmbito da empresa. (Ibid, p. 19, grifo da autora)

Esse relato se soma à nossa análise do questionário aplicado aos Pontos Focais que, mesmo com a observação de não identificação dos mesmos, alguns empregados preferiram não se identificar. Como descrevemos neste estudo, a cultura do segredo, do medo, parece ainda estar presente na empresa.

Nos registros dos resultados em cada um dos temas objeto da avaliação, o item 14 trata do detalhamento da avaliação da "Transparência da pessoa jurídica". Há neste item um destaque em relação aos contratos firmados, no qual foi observado que a ECT divulga apenas os contratos em que figura como contratante. A expressão "Para Fornecedores", utilizada quando se tem acesso a essa página, foi criticada como não sendo a mais adequada. Os auditores avaliaram que essa linguagem sugere que a opção de consulta se destina apenas aos contratados e fornecedores da ECT, e não a qualquer visitante da página. Sobre essa crítica da CGU, o próprio SIC-ECT já havia solicitado à Central de Compras que alterasse o endereço eletrônico (informação pessoal), entretanto, não foram tomadas as providências devidas ${ }^{97}$.

Por fim, a CGU apresenta no relatório como sugestão de melhoria "adotar linguagem cidadã para as informações divulgadas no seu portal da internet, especialmente no que se refere

\footnotetext{
97 Até a conclusão desta pesquisa, em 30 de novembro de 2016, em nova visita à página na internet da ECT, confirmamos que permanece inalterada e sem a execução das orientações do Relatório de Integridade da CGU.
} 
aos contratos firmados, de forma a trazer mais clareza para os cidadãos que buscam informações da empresa."

Este relatório evidencia o esforço de estruturação do SIC-ECT para atendimento das demandas dos cidadãos e da estrutura de transparência da ECT, mas identifica a dificuldade na linguagem com os cidadãos, confirmada nas justificativas dos recursos registrados e na pesquisa de satisfação do cidadão, como veremos a seguir.

\subsection{Relatório da Pesquisa de Satisfação}

Histórico e Objetivo da Pesquisa de Satisfação

A Pesquisa de Satisfação do Cidadão está disponibilizada no Sistema Eletrônico de Acesso à Informação da Administração Federal (e-SIC) desde novembro de 2012, e fíca disponível aos requerentes quando estes acessam a resposta ao seu pedido de informação. O preenchimento da pesquisa não é obrigatório.

O objetivo da pesquisa, segundo a CGU, é permitir que os cidadãos possam avaliar se a informação fornecida atende suas expectativas, se a linguagem utilizada é compreensível e, inicialmente, avaliava também se o órgão estava sendo cordial e prestativo no atendimento. A pesquisa permite aos que tiveram acesso negado, avaliar a justificativa dada, e todos os usuários do e-SIC podem utilizar um campo livre para fazer comentários, elogios, críticas e sugestões sobre o atendimento da LAI.

O resultado da pesquisa fica disponível apenas aos gestores do SIC em cada órgão, e foi necessário solicitar à ECT, através do e-SIC, os dados para nosso estudo, conforme relatado na seção 1.4 , que trata da metodologia da pesquisa.

A CGU apresentou uma análise geral em sua publicação de balanço de três anos da LAI (BRASIL/CGU, 2015a, p. 22), em que informa que o índice de resposta à pesquisa é de 2\%.

No dia 2 de outubro de 2014, uma nova versão do sistema e-SIC foi liberada, com aprimoramentos na pesquisa. Segundo a CGU, tornando-a mais intuitiva e fácil de ser respondida pelo usuário. A pesquisa de satisfação passou a ser estruturada em três perguntas, duas objetivas com níveis de 1 a 5 e uma subjetiva. As perguntas têm variáveis de acordo com a resposta do órgão à demanda do usuário, que foram organizadas pela autora em dois grupos: "acesso totalmente concedido" e "demais opções" (acesso parcialmente concedido, acesso 
negado, ou outras hipóteses de negativa). A correlação entre o modelo anterior e o atual, e a forma como estruturamos a análise deste questionário, encontra-se no APÊNDICE C.

População de Estudo

O universo da pesquisa são os cidadãos que registraram pedido de informação no SICECT, no período de maio de 2012 a dezembro de 2015, totalizando 6.773 pedidos. Como a pesquisa só foi implantada em final de novembro de 2012, os dados a serem analisados correspondem ao período de dezembro/2012 a dezembro/2015, totalizando, assim, 5.649 pedidos de informação.

Responderam à Pesquisa de Satisfação 841 requerentes, representando 14,9\% do total de solicitantes de pedidos de informação registrados na ECT no período da existência da pesquisa, dezembro/2012 até dezembro/2015.

No Gráfico 19 percebemos o aumento na participação dos cidadãos em responder a Pesquisa de Satisfação, o que a longo prazo poderá subsidiar vários estudos sobre a percepção dos cidadãos e o atendimento que recebe dos órgãos públicos. O número de respondentes no ano de 2016, refere-se a pedidos registrados no ano de 2015 (NUP de 2015), que foram respondidos em 2016 (o prazo de 20 dias, prorrogáveis por mais 10 dias, possibilitam pedidos registrados em dezembro podem ser respondidos até janeiro do ano seguinte) pelo solicitante.

Gráfico 20 - Pesquisa de Satisfação SIC/ECT: nº de respostas dos solicitantes (2012/2015)

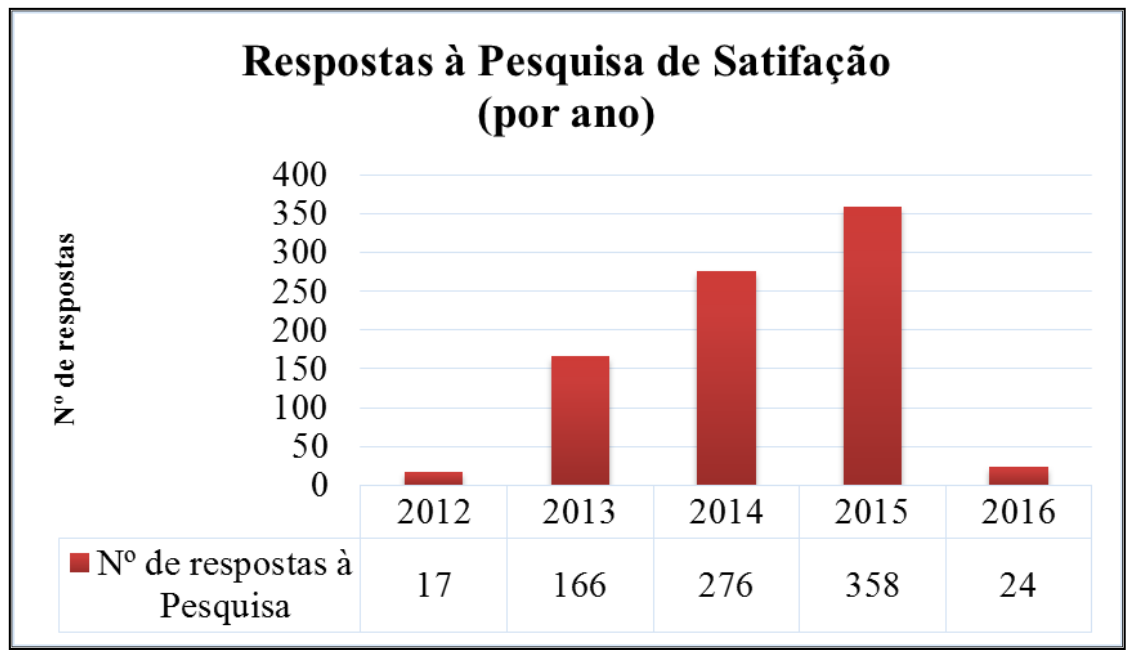

Fonte: elaborado pela autora

A Tabela 15 está organizada na primeira coluna com os tipos de respostas dada pela ECT; na segunda coluna o total de pedidos respondidos pelo SIC-ECT respectivo ao tipo de resposta; na terceira coluna, a quantidade de solicitantes que respondeu à Pesquisa de Satisfação 
correspondente ao tipo de resposta recebida; na quarta coluna, o percentual dos que responderam com relação ao tipo de resposta da ECT; e na quinta coluna, o percentual dos que responderam à Pesquisa de Satisfação por cada tipo de resposta com relação ao total dos que responderam ao questionário.

Verificamos primeiramente que tendo a ECT respondido com acesso concedido para $79 \%$ dos pedidos de informação, cerca de 19,2\% dos que tiveram acesso negado responderam à pesquisa, seguido de $16,5 \%$ dos que receberam acesso concedido. Há nesse resultado uma tendência dos solicitantes não satisfeitos com a respostas usarem a pesquisa para demonstrar sua insatisfação.

No cômputo quantitativo dos que responderam ao questionário, 88,1\% receberam da empresa suas respostas com o tipo de resposta "acesso concedido".

Tabela 15 - Pesquisa de Satisfação SIC/ECT: Tipo de Resposta Recebida

\begin{tabular}{|c|c|c|c|c|}
\hline \multicolumn{5}{|c|}{ PESQUISA DE SATISFAÇÃO - Periodo de dez/2012 a dez/2015 } \\
\hline $\begin{array}{l}\text { Pedido de Informação: Tipo de } \\
\text { Resposta dada pela ECT }\end{array}$ & $\begin{array}{c}\text { Total de } \\
\text { Pedidos de } \\
\text { Informação }\end{array}$ & $\begin{array}{l}\text { Respostas à } \\
\text { Pesquisa de } \\
\text { Satisfação }\end{array}$ & $\begin{array}{l}\%(\text { tipo de } \\
\text { resposta) }\end{array}$ & $\begin{array}{l}\%(\text { ao total de } \\
\text { resposta } P S)\end{array}$ \\
\hline Acesso Concedido & 4.495 & 741 & 16,5 & 88,1 \\
\hline Acesso Negado & 308 & 59 & 19,2 & 7,0 \\
\hline Acesso Parcialmente Concedido & 166 & 15 & 9,0 & 1,8 \\
\hline Informação Inexistente & 88 & 5 & 5,7 & 0,6 \\
\hline Não se trata de solicitação de informação & 427 & 8 & 1,9 & 1,0 \\
\hline $\begin{array}{l}\text { Órgão não tem competência para } \\
\text { responder sobre o assunto }\end{array}$ & 42 & 4 & 9,5 & 0,5 \\
\hline Pergunta Duplicada/Repetida & 123 & 9 & 7,3 & 1,1 \\
\hline $\begin{array}{c}\text { Total de Pedidos de Informação e } \\
\text { pesquisa respondida }\end{array}$ & 5.649 & 841 & 14,9 & \\
\hline
\end{tabular}

Fonte: elaborado pela autora com base no Relatório da Pesquisa de Satisfação

Na Tabela 16 constatamos que 32\% tiveram seus pedidos prorrogados por mais dez dias e apenas $8 \%$ receberam suas respostas fora do prazo de 30 dias. 
Tabela 16 - Pesquisa de Satisfação SIC/ECT: Cumprimento de Prazos
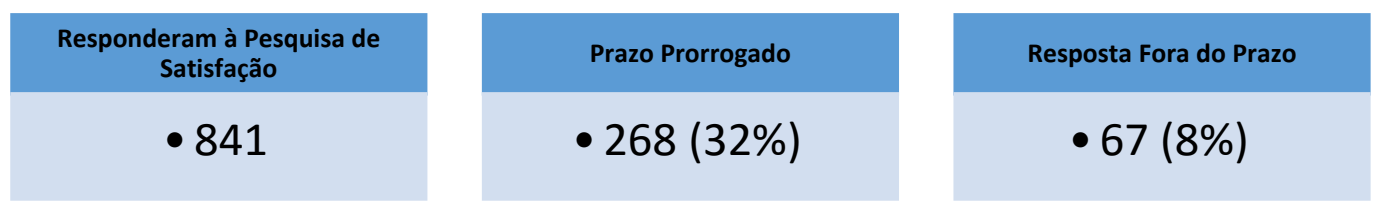

Fonte: elaborado pela autora com base nos dados brutos da Pesquisa

Portanto, $82 \%$ dos que responderam à pesquisa de satisfação, receberam a resposta da ECT dentro dos prazos legais e, segundo os gestores da empresa, obtiveram acesso à informação solicitada.

Análise das Respostas à Pesquisa de Satisfação

No Apêndice C apresentamos um Relatório da Pesquisa de Satisfação em que descrevemos a metodologia adotada para o cálculo dos percentuais nas Tabelas 17 e 19 .

A análise quanto as perguntas e respostas dos que receberam da ECT o tipo de resposta “acesso concedido" está organizada na Tabela 16. Verificamos que 67,6\% dos respondentes consideram que a resposta ofertada pela ECT foi de fácil compreensão, mas consideram que a ECT não atendeu ao seu pedido, apesar de constar como acesso concedido. A pergunta 3 foi retirada da pesquisa a partir de 2014, nas respostas existente verifica-se que 70,7\% consideraram que a ECT foi cordial e prestativa.

Tabela 17 - Pesquisa de Satisfação SIC/ECT: ACESSO CONCEDIDO

\begin{tabular}{lccc|}
\multicolumn{1}{c}{ Acesso Conce dido } & $\begin{array}{c}\text { Atendeu/Concordo } \\
(\%)\end{array}$ & $\begin{array}{c}\text { Não } \\
\text { Atende u/Não } \\
\text { Concordo (\%) }\end{array}$ & $\begin{array}{c}\text { Atende u/Não } \\
\text { Atendeu (\%) }\end{array}$ \\
\hline $\begin{array}{l}\text { A resposta fornecida foi de } \\
\text { fácil compreensão? }\end{array}$ & 67,6 & 28,1 & 4,3 \\
$\begin{array}{l}\text { A resposta fornecida atendeu } \\
\text { plenamente ao seu pedido? }\end{array}$ & 38,9 & 58,4 & 2,7 \\
$\begin{array}{l}\text { O órgão foi prestativo e cordial } \\
\text { na resposta. }\end{array}$ & 70,7 & 29,3 & 0,0 \\
\hline
\end{tabular}


A pergunta 4 da pesquisa é aberta para comentários e 50,8\% dos solicitantes registraram suas observações sendo a maioria de críticas à empresa, em consonância com a pergunta 2 onde a maioria respondeu que a ECT não atendeu plenamente ao seu pedido. Selecionamos algumas das frases presentes nos comentários de críticas e elogios.

Tabela 18 - Pesquisa de Satisfação SIC/ECT: Comentários ACESSO CONCEDIDO

\section{Pergunta 4 - Comentários: Tipo de Resposta "Acesso Concedido"}

Agradeço o envio da informação, que será uma fonte de informações para pesquisas futuras.

Acho que esse tipo de informação deveria estar disponível no site da empresa.

Agradeço pela resposta mas ainda não estou satisfeito.

O Serviço de Informação ao Cidadão é um excelente meio para à prática da cidadania. Contudo, acredito, ainda falta uma maior divulgação do serviço. No meu caso,por exemplo, acabei descobrindo o serviço ao acaso, pois não sabia que o mesmo existia!

Parabenizo pela rapidez e transparência na resposta ao pedido de informação.

Parabéns aos Correios que tem, entre seus funcionários, pessoas que conhecem, profundamente, a LAI, Lei de Acesso a Informação. MUITO OBRIGADO

Parabéns pelo pronto atendimento, necessitamos que todos os funcionários públicos fossem assim prestativos e eficientes.

Prezados. Solicito que a resposta seja enviada por meio de carta via fisica, conforme a solicitação inicial.

Quero agradecer pela resposta da minha solicitação.

Recebi em minha residência. Obrigada.

Recebi os arquivos gravados em CD via correios.

Registro meus agradecimentos pela atenção dispensada e pelas informações disponibilizadas.

respondido muito superficialmente sem uma ponto conclusivo resposta muito vaga sem uma definiçao

REsposta atendeu plenamente a expectativa.

Resposta precisa e eficaz

Respostas não tinham embasamento/comprovação das informações e apresentou diversas pontos confusas. Alem de não ter respondido uma pergunta.

Fonte: elaboração da autora com base na Pesquisa de Satisfação 
A resposta dos solicitantes que receberam como tipo de resposta "Acesso Negado; Acesso Parcialmente Concedido, Informação Inexistente; Não se trata de solicitação de informação; Órgão não tem competência para responder sobre o assunto e Pergunta Duplicada/Repetida" estão agrupadas como "Demais Opções".

As perguntas na Pesquisa diferem das perguntas de quem recebeu acesso concedido e estão organizadas na Tabela 19.

Verificamos que a maioria dos respondentes (55\%) consideram que a justificativa fornecida pela ECT não foi de fácil compreensão e nem que a justificativa para a negativa de acesso foi satisfatória (76\%). Apenas para uma pequena maioria $(54,5 \%)$ a ECT foi cordial e prestativa.

Tabela 19 - Pesquisa de Satisfação SIC/ECT: DEMAIS OPÇÕES

\begin{tabular}{lccc}
\multicolumn{1}{c}{ Fácil Compreensão / } \\
\multicolumn{1}{c}{ Demais Opções } & $\begin{array}{c}\text { Difícil } \\
\text { Compreensão / } \\
\text { (\%) }\end{array}$ & $\begin{array}{c}\text { Não } \\
\text { Atende u/Não } \\
\text { Concordo (\%) }\end{array}$ & $\begin{array}{c}\text { Atende u/Não } \\
\text { Atendeu (\%) }\end{array}$ \\
$\begin{array}{l}\text { Ajustificativa fornecida foi de } \\
\text { fácil compreensão? }\end{array}$ & 39,0 & 55,0 & 6,0 \\
$\begin{array}{l}\text { A justificativa fornecida } \\
\text { atendeu plenamente ao seu } \\
\text { pedido? }\end{array}$ & 16,0 & 76,0 & 8,0 \\
$\begin{array}{l}\text { O órgão foi prestativo e cordial } \\
\text { na resposta. }\end{array}$ & 45,5 & 54,5 & 0,0 \\
\hline
\end{tabular}

Fonte: elaboração da autora com base na Pesquisa de Satisfação

A pergunta 4, como no anterior, é uma pergunta aberta e 56\% escreveram comentários, sendo, na ampla maioria, com críticas negativas à empresa. Na Tabela 20 apresentamos alguns dos comentários que selecionamos, em que a insatisfação com a resposta, dificuldade de compreensão e a questão do CEP e sigilo, aparecem nos comentários dos cidadãos. 
Tabela 20 - Pesquisa de Satisfação SIC/ECT: Comentários DEMAIS OPÇÕES

\section{Pergunta 4 - Comentários: Tipo de Resposta "Demais opções"}

14 dias para uma resposta padrão como essa...

A informação requisitada está disponível no própio site dos Correios para consulta. Não concordo que se trata de informação sigilosa.

A resposta argumenta que a informação solicitada é parte integrante de um produto comercializado pelos Correios, o e-DNE. Na realidade, não existe um produto material, como software ou algum mecanismo de acesso à informação. O que é comercializado é exatamente um arquivo, ou conjunto de arquivos, em formato TXT, contendo informação sobre o CEP em escala nacional. Sendo assim, sua comercialização está em desacordo com a Lei 12527/2011, e a solução "BUSCA CEP" não provê todas as modalidades de acesso previstas no Art 8o. parágrafo 3o. da referida Lei.

A resposta não possui informação suficiente para justificar a dificuldade no acesso automatizado dos dados produzidos pela entidade.

Argumentou demais e não respondeu nos termos solicitados.

Cita negação por " Dispositivo Legal" que desconheço totalmente.

Então existe um "Órgão detentor da Informação", ao qual a ECT diz não pertencer a mesma. Pergunta:

Que orgão é esse e como fazer contato com ele?

demorar um mês para dizer que não pode, primeiro eu não formalizei corretamente foi um mês, depois formalizei demorou um mes para dizer que não pode?????

FOI ALEM DAS MINHAS ESPECTATIVAS, POIS A 17 ANOS BUSCA UMA SOLUÇÃO SEM SUCESSESO, GRATA.

Informação incompleta e ineficiente.

iNFORMAÇÃO NÃO COMPREENDIDA.

Muito bom dia!!! Não precisa demorar 20 dias para responder que o pedido não foi especifico.

Tentativa clara de escapatória em responder pergunta objetiva e precisa. 
$\mathrm{Na}$ análise de dados apresentamos o espectro do ciclo que envolve o acesso a informação através da LAI na ECT: o SIC, os Pontos Focais, os órgãos de controle e o cidadão.

Pelo SIC/ECT verificamos não apenas o quantitativo de pedidos e recursos, os principais temas, as razões de negativa e os principais motivos de recursos, mas apresentamos dois casos (que passaram por negativa de acesso e registro de recurso) que impactam no acesso a informação e nos remetem ao debate sobre o que é informação pública e porque não é de acesso a sociedade. O Código de Endereçamento Postal (CEP) e os salários dos empregados públicos.

Pelos Pontos Focais verificamos, através do questionário aplicado, como os empregados públicos, que em nome da empresa, coordenam e encaminham as respostas que são enviadas ao cidadão, percebem a informação - quanto ao tempo, ao conteúdo, à forma e à localização; a gestão documental; as mudanças de cultura e procedimentos com a implantação da LAI e a visão de transparência pública. Percebemos que não há muitas diferenças quanto as destacadas no Sumário-Executivo da CGU (BRASIL/CGU, 2011c, 2011), relativas ao controle da informação, aos problemas operacionais, e da dificuldade em romper a cultura organizacional da cultura do segredo para a cultura do acesso.

Pelos órgãos de controle, a CGU vem atuando no seu papel de monitoramento da LAI e fiscalização de cumprimento das normas de transparência pública. O Relatório de Avaliação da Integridade em Empresas Estatais, mostrou a identificação de um problema que na Pesquisa de Satisfação, os cidadãos que receberam como resposta "acesso negado" também identificaram, que é a necessidade da empresa adotar uma linguagem amigável ao cidadão. Uma linguagem mais clara e de fácil compreensão.

E, por fim, a participação do cidadão. Apesar de um percentual ainda pequeno de participação dos solicitantes na pesquisa, cerca de $15 \%$ ao longo dos três anos analisados, é possível verificar que vem crescendo essa participação e poderá ser, em breve um excelente instrumento de análise do atendimento da LAI sob o olhar do cidadão. Há nas respostas dos cidadãos indicadores de que, apesar da empresa considerar que concedeu acesso à informação, a maioria considera que a resposta enviada não atendeu plenamente ao seu pedido; assim como os que tiveram negado esse acesso, consideraram que justificativa dada não os atendeu plenamente. 


\section{CONSIDERAÇÕES FINAIS}

O presente estudo teve como objetivo responder ao problema apresentado que consiste em identificar de que maneira a condição de empresa híbrida dos Correios influi na aplicação da LAI quanto à transparência das informações e identificar como a cultura organizacional dos Correios influencia na organização e acesso às suas informações após a promulgação da LAI.

Ao analisar a transformação do DCT em ECT, uma empresa pública, constata-se uma mudança profunda na organização que é objeto constante de debates jurídicos e organizacionais. A discussão ocorrida, em 2009, no Supremo Tribunal Federal, sobre a manutenção do monopólio postal, possibilita-nos identificar os conflitos quanto a concepção de serviço postal que permeou o debate, envolvendo a prestação de serviço público e a atividade econômica, identificando assim, a empresa como de regime híbrido. Esse conflito se reflete na organização da informação, na gestão documental, e há indícios de que tenha influenciado um distanciamento da empresa das práticas típicas da administração pública. Um dos indícios, que foi analisado nesta pesquisa, foi o processo de Inquérito Civil do MPF levado à CPMI dos "Correios" - o "Mensalão dos Correios", que acarretou uma imagem negativa para a ECT, em que identificamos, através do TAC, os destaques à gestão documental, às práticas de licitação e outras em discordância com a legislação para a administração pública.

A estrutura da administração indireta na administração pública federal, construída no regime militar, é um fator crucial para o debate do controle social sobre os órgãos públicos. $\mathrm{O}$ que se depreende, após a análise do Estado brasileiro, da cultura do sigilo, e dos Decretos-Lei, que instituíram a ECT, é a dificuldade de o cidadão ter acesso às informações, uma vez que se ancoram na competitividade do mercado para negar algumas informações.

Evidenciamos, neste estudo, que a ECT não apresentava, até 2011, uma prática de gestão documental em consonância com a legislação em vigor e que garantisse aos órgãos de controle, e à sociedade, acesso às informações que ela produzia. A análise dos relatórios da CPMI dos “Correios", das respostas aos cidadãos, e de sua organização interna, depreende-se a ausência de gestão pública, utilizando-se do status de regime hibrido, com ênfase no direito privado.

Para a Ciência da Informação a análise sobre a Empresa Brasileira de Correios e Telégrafos tem um sentido mais amplo. É uma empresa responsável no país pelos serviços postais, no qual a informação é seu principal ativo. A ECT ao prestar um serviço de levar de um ou vários remetentes, à um ou vários destinatários um documento, uma carta, um telegrama, 
um objeto, está exercendo o papel de viabilização do acesso à informação para a sociedade. A importância desta atividade é tanta que em momentos históricos, em que a democracia é suprimida, ela é alvo de controle e censura, como evidenciamos no estudo. Mesmo com as novas tecnologias, como a internet, ainda existem milhões de pessoas que utilizam o serviço postal para troca de informações. No Brasil, $58 \%$ da população tem acesso à internet ${ }^{98}$, ou seja, para um contingente de $42 \%$ dos brasileiros, em várias cidades e vilarejos, é o carteiro que faz o transporte da informação, utilizando todos os meios possíveis (caminhando, de bicicleta, de moto ou de carro).

Neste sentido o debate sobre o CEP se apresenta com destaque pela importância que tem para a sociedade brasileira. Qualquer cidadão, pessoa física ou jurídica, para postar e receber, qualquer carta ou correspondência ou mesmo uma encomenda através da empresa pública ECT, sabe que é indispensável informar o CEP correto e atualizado para o bom cumprimento do serviço postal. O serviço postal está presente na Constituição Federal como sendo de competência da União a sua manutenção. A posição do Brasil no ranking de Dados Abertos mostra o quanto a não disponibilização desta informação reflete na sua classificação (Figura 2, p.67).

O CEP é um mecanismo de organização espacial, necessário para projetos de georeferenciamento e para o desenvolvimento das pequenas e médias empresas, e não está com sua base de dados disponível para os cidadãos. A CGU reconhece que é uma informação pública, e não propriedade comercial da ECT, mas que continua sendo negada uma vez que a CMRI considerou a observância da Lei Postal. Entretanto esta não é uma decisão final. A sociedade brasileira já conviveu com o livre acesso a todos os CEPs consultando às listas impressas e em várias cidades estão nas placas de sinalização de cada rua. Entretanto, verificamos que o advento da informação eletrônica ao invés de facilitar o acesso à informação aos cidadãos, trouxe limitação ao priorizar a atividade econômica sobre a prestação de serviço público. O caráter híbrido da empresa restringindo o acesso à informação.

Já o salário dos empregados públicos não pode ser definido por ato discricionário, ele é fruto de decisão pública - negociação com os sindicatos, acórdãos do TST, deliberações nos colegiados da empresa. Entretanto, em nome do regime concorrencial, do caráter híbrido da empresa, há restrição ao acesso público.

\footnotetext{
98 Pesquisa TIC Domicílios 2015, do Comitê Gestor da Internet No Brasil - CGI.Br, p. 28, disponível em < http://www.cgi.br/media/docs/publicacoes/2/TIC_Dom_2015_LIVRO_ELETRONICO.pdf $>$.
} 
Qualquer atividade ou serviço prestado pela empresa pública pode ser considerado de interesse da população, uma vez que é em nome da União, da população brasileira, que a empresa atua no mercado concorrencial. A CPMI dos Correios foi um processo desencadeado por uma denúncia de corrupção envolvendo um empregado público da ECT, neste sentido, a gestão da empresa é de interesse público.

A ECT é uma empresa pública em que a União é a única acionista. Cabe a União dar as garantias para a comunicação privada entre pessoas, para a integração nacional e preservar o sigilo da correspondência, como aqui destacamos na fala do ministro do STF. A saída salomônica apresentada pelo Supremo, separando as atividades em que uma é serviço público e a outra é concorrencial e, portanto, está sujeita à competitividade do mercado, não resolve o problema das informações públicas que a empresa tem em seu poder. Os agentes de correios, empregados públicos com seus uniformes exclusivos - amarelo e azul, estão todos os dias na casa de cada brasileiro e brasileira com a confiança da população, para a entrega de seus objetos, sejam eles correspondências de monopólio, sejam eles encomendas de compras pela internet. Sejam documentos privados de grande importância, seja uma carta de amor. São informações, comunicações entre pessoas, que o cidadão ao escolher enviar pela empresa pública, pressupõe a confiança no serviço público. A concorrência existente hoje no Brasil se concentra nas grandes cidades e não atinge a totalidade de nosso país com dimensões continentais, e dificilmente atingirá pela busca da lucratividade, e nem sempre no atendimento à população como um todo.

O serviço postal, tem característica que diferem do serviço bancário, energético, de saúde, de educação etc., em que o cidadão se desloca ao encontro do serviço público, ou privado, que melhor lhe convém. O serviço postal, enquanto existir o objeto físico e material, necessitará de mensageiro para a conclusão do processo e, como qualquer informação, precisa de confiabilidade, autenticidade e integridade.

Nas respostas dos Ponto Focais do SIC, quanto a transparência da empresa (Tabela 14, p.223), quando apresentado o regime híbrido da empresa, constata-se a dicotomia do público e privado, ao concordarem enfaticamente com a afirmativa de sendo os Correios uma empresa pública suas informações deveriam ser transparentes, para depois se dividirem quanto a disponibilizar essas informações.

O padrão geral das respostas dos Pontos Focais no questionário evidenciou a existência de dois perfis de atuação quanto ao cumprimento da LAI na empresa, um mais distante e que trata o assunto como uma tarefa, se limitando à sua área de atuação na empresa; e outro mais atuante e na busca de conhecer a empresa como um todo. Um reflexo na cultura organizacional 
em que aqueles que viveram no período da cultura do silencio se limitavam a sua área de atuação e de opacidade, e a convivência com uma nova geração, ingressantes após 1980, que demonstram maior abertura à novas experiências.

Identificamos que o entendimento da CGU, e de boa parte dos gestores da empresa estatal ECT é que o caráter híbrido justifica a negativa de acesso às informações pelos cidadãos, nos casos do CEP e dos salários. Com essa visão, a ECT não estaria obrigada a atender pedidos de informação que possam afetar sua vantagem competitiva e comprometer sua estratégia empresarial. No caso do CEP, uma posição que desconsidera os argumentos que garantiram no STF, em 2009, a permanência do monopólio postal.

Outro elemento destacado é a linguagem e o tratamento para com o cidadão que se apresenta tanto na Pesquisa de Satisfação, quanto no Relatório de Integridade da CGU, no qual se faz necessária uma melhor comunicação e atenção. A necessidade de incorporar a linguagem cidadã é um reflexo da distância dos gestores da empresa para com a sociedade, diferente da maioria de seus empregados que estão cotidianamente na casa de cada um dos brasileiros.

A Lei de Responsabilidade das Estatais, Lei 13.303, de 30 de junho de 2016, apresenta vários mecanismos de transparência e governança, especificando a divulgação de várias informações das empresas, que, esperamos, possam contribuir com uma mudança de postura mais efetiva. A globalização, as transformações recentes, as legislações, como LRF e LAI, e agora a LRE, indicam que a responsabilidade social das empresas públicas deve ser assumida e ela precisa ser permeável à sociedade. Mas o que é desejável é o compromisso social da empresa com a sociedade que se concretiza com a Transparência de suas informações e ações.

Os normativos de transparência pública citados neste estudo nasceram sob a égide da construção de um Estado Democrático de Direito, iniciado no Brasil com a Constituição Cidadã de 1988 e aprofundados nessa última década, nos governos Lula e Dilma. O afastamento da Presidenta Dilma, identificado como um golpe de Estado, um golpe na democracia brasileira, pode significar impor freios ao processo de democratização da sociedade, em que se baseia a defesa da transparência pública e do acesso à informação aos cidadãos.

Ao destacar a organização e o acesso à informação na ECT, os limites que carrega desde a sua criação, buscamos contribuir com a sociedade brasileira no controle social de nossas empresas estatais e na sua sustentabilidade. Ao trazer para o debate os dilemas público e privado, monopólio e concorrencial, informação pública ou restrita, o medo e a liberdade, o sigilo e a transparência, estamos principalmente trazendo o debate sobre o Estado. Converter o Estado de órgão que está por cima da sociedade num órgão completamente a ela subordinado, é nisto que a liberdade consiste, segundo Marx. E é este o Estado que buscamos. 
A ECT tem uma grande importância na vida dos brasileiros e uma maior transparência e democratização na sua gestão é um dos caminhos para a construção de um Estado subordinado à sociedade. 


\section{SUGESTÕES PARA NOVAS PESQUISAS}

Alguns temas e ideias não puderam ser explorados de forma exaustiva, durante o desenvolvimento da pesquisa, para que pudesse manter-se o escopo inicial. Assim como, os resultados desta pesquisa indicam novas possibilidades de análises e estudos, a partir de novos problemas de pesquisa. Destacamos os seguintes estudos:

a) Analisar o papel social e político da ECT enquanto instituição de informação, à luz da literatura da Ciência da Informação;

b) Analisar normas e práticas gerenciais, relacionadas ao acesso à informação, de outras organizações com a mesma característica híbrida dos Correios;

c) Verticalizar a análise dos dados contidos no Relatório da Pesquisa de Satisfação do Cidadão, tendo em vista a necessidade de atendimento às demandas geradas pela LAI;

d) Analisar caráter de informação pública do Código de Endereçamento Postal e a política de Dados Abertos do Governo Federal;

e) Analisar o papel das instâncias - CGU e CMRI - quanto à análise dos recursos como órgãos de governo e os interesses dos cidadãos. 


\section{REFERÊNCIA}

ABRUCIO, Fernando Luiz. Trajetória recente da gestão pública brasileira: um balanço crítico e a renovação da agenda de reformas. Revista de Administração Pública. Rio de Janeiro:

Edição Especial Comemorativa 67-86, 1967-2007, jun/2007. Disponível em $<$ http://www.scielo.br/pdf/rap/v41nspe/a05v41sp.pdf>. Acesso em 27.set.2015

ACIOLI, Bruno Caiado de. A importância do GED nas investigações do Ministério Público. Palestra proferida no $2^{\circ}$ Painel: A importância da Gestão Documental nas Ações de Controle e debate correspondente - PGR: Audiência Pública sobre Gestão Eletrônica de Documentos GED - Desafios e Perspectivas. Brasília, DF - realizada em 5.jul.2011. Disponível em < file://C:/Users/A/Downloads/apresentacao\%20dr\%20bruno.pdf >

ALTHUSSER, Louis; BADIOU, Alain. Materialismo Histórico e Materialismo Dialético. São Paulo, SP: Global Editora e Distribuidora Ltda., 1a edição - maio/1979 (p. 33 - 56);

ANGÉLICO, Fabiano. Lei de acesso à informação pública e seus possíveis desdobramentos à accountability democrática no Brasil. Dissertação Mestrado FGV. 2012. Disponível em < http://bibliotecadigital.fgv.br/dspace/handle/10438/9905>. Acesso em 07.jun.2015

ARAÚJO, Carlos Alberto Ávila. Arquivologia, Biblioteconomia, Museologia e Ciência da Informação: o diálogo possível. Brasília, DF: Briquet de Lemos, São Paulo: Associação Brasileira de Profissionais da Informação (ABRAINFO), 2014.

ARAÚJO JÚNIOR, R. H. de; SOUSA, R. T. B. de; ALBUQUERQUE, S. F. de. Métodos, técnicas e instrumentos de organização e gestão da informação nas organizações. In:

BAPTISTA, D. M.; ARAÚJO JÚNIOR. R. H. de. (Orgs.). Organização da informação: abordagens e práticas. Brasília: Thesaurus, 2015, p. 44-68.

BARACCHINI, A, P. O sigilo dos arquivos vinculados ao regime militar e o direito constitucional à informação: uma questão de cidadania. Revista Eletrônica do Curso de Direito da UFSM, Santa Maria, v. 3, n. 2, p. 120-133, jun.2008. Disponível em: < http://periodicos.ufsm.br/revistadireito/article/view/6862\#.V5YBIrgrLIU > . Acesso em 22.jun. 2016

BARROS NETO, J. P. Administração Pública no Brasil: uma breve história dos Correios. São Paulo: Annablume, 2004.

BARROSO, Luís Roberto. Regime constitucional do serviço postal - Legitimidade da atuação da iniciativa privada. Revista de Direito Administrativo, Rio de Janeiro, n. 222, p. 179-212, out./dez. 2000. Disponível em: <

http://bibliotecadigital.fgv.br/ojs/index.php/rda/article/download/48944/47554 >. Acesso em 8.nov.2015

BELKIN, N.J. Information concepts for information Science. Journal of Documentation, v.34, n.1, p. 55-85, march 1978. Disponível em: < http://www.emeraldinsight.com/doi/abs/10.1108/eb026653>. 
BENSAID, Daniel; LOWY, Michael. Marxismo, modernidade e utopia. $1^{\text {a }}$ Edição, São Paulo: Xamã Editora, 2000.

BENTO, Leonardo Valles; BRINGEL, Polyana de Oliveira Martins. LIMITES À TRANSPARÊNCIA PÚBLICA DAS EMPRESAS ESTATAIS: análise crítica da aplicação da Lei de Acesso a Informação (Lei no 12.527/2011) a Empresas Públicas e Sociedades de Economia Mista. Direito e administração pública I [Recurso eletrônico on-line] organização CONPEDI/UFPB, - Florianópolis: CONPEDI, 2014, pag. 356 - 383. Disponível em $<$ http://www.publicadireito.com.br/artigos/? $\operatorname{cod}=$ c139ffc26fbaf2d1 $>$. Acesso em 4.set.2016

BOBBIO, Norberto. Democracia e Segredo. Organização Marco Revelli; tradução Marco Aurélio Nogueira. $1^{a}$ edição, São Paulo: Editora Unesp, 2015.

BOBBIO, Norberto. Nem com Marx, Nem contra Marx. Organização Carlo Violi; tradução Marco Aurélio Nogueira. - São Paulo: Editora UNESP, 2006.

BORKO, H. Information science: what is it? American Documentation, v. 19, n. 1, p. 3-5, 1968 apud SARACEVIC, T. Ciência da Informação: origem, evolução e relações.

Perspectivas em Ciência da Informação, Belo Horizonte, v. 1, n. 1, p. 41-62, jan./jul. 1996. Disponível em: $<$ http://portaldeperiodicos.eci.ufmg.br/index.php/pci/article/view/235/22 > . Acesso em: 14 ago.2014.

BOURDIEU, Pierre. Sobre o Estado: Cursos no Collège de France (1989-92). Tradução Rosa Freire d'Aguiar - 1 ${ }^{\text {a }}$ edição - São Paulo: Companhia das Letras, 2014.

BOVO, C. Os Correios no Brasil e a Organização Racional do Trabalho. São Paulo: Annablume, 1997. Disponível em < https://books.google.com.br/books?id=7Oc5G$1 \mathrm{sRegC \& printsec}=$ frontcover\&hl $=\mathrm{ptPT} \&$ source $=\mathrm{gbs} \_g e$ summary_r\&cad $=0 \# \mathrm{v}=$ onepage \&q\& $\mathrm{f}=$ false $>$. Acesso em 20.jun.2016

BOTTOMORE, Tom. Dicionário do Pensamento Marxista. Tradução Waltensir Dutra - $1^{\text {a }}$ edição brasileira - Rio de Janeiro: Editora Zahar, 1988.

BRASIL. Ato Institucional n ${ }^{\circ}$, de 9 de abril de 1964. Dispõe sobre a manutenção da Constituição Federal de 1946 e as Constituições Estaduais e respectivas Emendas, com as modificações introduzidas pelo Poder Constituinte originário da revolução Vitoriosa. Diário Oficial [da] União, Brasília, DF, de 11.abr.1964 -. Disponível em $<$ http://www.planalto.gov.br/ccivil_03/AIT/ait-01-64.htm>. Acesso em 05.nov.2015.

. Ato Institucional $\mathrm{n}^{\circ} 4$, de 7 de dezembro de 1966. Convoca o Congresso Nacional para se reunir extraordinariamente, de 12 de dezembro de 1966 a 24 de janeiro de 1967, para discursão, votação e promulgação do projeto de Constituição apresentado pelo Presidente da República, e dá outras providências. Diário Oficial [da] União, Brasília, DF, de 12.dez.1966 -. Disponível em <https://www.planalto.gov.br/ccivil_03/AIT/ait-04-66.htm>. Acesso em 05.nov.2015.

Ato Institucional no 5, de 13 de dezembro de 1968. São mantidas a Constituição de 24 de janeiro de 1967 e as Constituições Estaduais; O Presidente da República poderá decretar a intervenção nos estados e municípios, sem as limitações previstas na Constituição, 
suspender os direitos políticos de quaisquer cidadãos pelo prazo de 10 anos e cassar mandatos eletivos federais, estaduais e municipais, e dá outras providências. Diário Oficial [da] União, Brasília, DF, de 13.dez.1968 -. Disponível em $<$ https://www.planalto.gov.br/ccivil_03/AIT/ait-05-68.htm>. Acesso em 05.nov.2015.

. Congresso Nacional. Relatório Final dos Trabalhos da CPMI dos "Correios" Volume III, 2006. Congresso Nacional. Brasília, DF, 2006. Disponível em $<$ http://www.senado.leg.br/comissoes/CPI/RelatorioFinalVol3.pdf >. Acesso em 15.out.2015

Constituição da República Federativa do Brasil de 1988. Brasília, DF: Senado, 1988. Disponível em $<$ http://www.planalto.gov.br/ccivil_03/constituicao/ConstituicaoCompilado.htm>. Acesso em: 02.jun.2015.

. Controladoria-Geral da União. Audiência Pública sobre Gestão Eletrônica de Documentos - Desafios e Perspectiva (Inquérito Civil nº 1.16.000.000919/2005-09). Brasília, DF, 2011a. Disponível em $<$ http://www.cgu.gov.br/sobre/institucional/eventos/anos-anteriores/2011/audiencia-publicasobre-gestao-eletronica-de-documentos/programacao.pdf $>$. Acesso em 02.jun.2016

Controladoria-Geral da União. Sumário Executivo: Pesquisa Diagnóstico sobre Valores, Conhecimento e Cultura de Acesso à Informação Pública no Poder Executivo Federal Brasileiro. Coordenação Prof. PhD Roberto DAMATTA. Brasília, DF, Dezembro/2011c. Disponível em $<$ http://www.acessoainformacao.gov.br/central-deconteudo/publicacoes/arquivos/pesquisadiagnostico.pdf.> Acesso em 30.nov.2016.

Controladoria-Geral da União. $1^{\circ}$ Balanço da Lei $\mathbf{n}^{0}$ 12.527: Lei de Acesso à Informação, Poder Executivo Federal 2011-2012. Brasília, maio.2013a. Disponível em $<$ http://www.acessoainformacao.gov.br/central-deconteudo/publicacoes/arquivos/balancolano.pdf $>$. Acesso em 02.jun.2016

Controladoria-Geral da União. $3^{\circ}$ Relatório de Implantação da Lei no 12.527: Lei de Acesso à Informação, Poder Executivo Federal 2014. Brasília, DF, 2015a. Disponível em http://www.acessoainformacao.gov.br/central-deconteudo/publicacoes/arquivos/relatorio_3anos_web.pdf. Acesso em 02.jun.2016

Controladoria-Geral da União. Brasil rumo a uma cultura de acesso à informação. Brasília, DF, 2012. Disponível em $<$ http://escolavirtual.cgu.gov.br/ead/course/category.php?id=15>. Acesso em 30.jan.2015.

Controladoria Geral da União. Cartilha de Acesso a Informação. Brasília, DF: 2011b. Disponível em <http://www.acessoainformacao.gov.br/central-deconteudo/publicacoes/arquivos/cartilhaacessoainformacao.pdf $>$. Acesso em 10.jun.2015.

. Controladoria Geral da União. DESPACHO no 4775 de 20/06/2013. Referência: 99923.001172/2012-06 Assunto: Recurso interposto por cidadão à CGU contra decisão denegatória de acesso à informação, com fundamento no art. 23 do Decreto no 7.724, de 16 de maio de 2012. Brasília, DF, 20.jun.2013b. Disponível em 
$<$ http://www.acessoainformacao.gov.br/precedentes/ECT/99923001172201206.pdf $>$. Acesso em 11.out.2015.

. Controladoria Geral da União. PARECER no 2979 de 24/07/2014. Referência: 99923.001660/2013-96 Assunto: Recurso contra acesso incompleto à informação. Brasília, DF, 20.jun.2013c. Disponível em $<$ http://www.acessoainformacao.gov.br/precedentes/ECT/99923001660201396.pdf>. Acesso em 11.out.2015.

Controladoria Geral da União. PARECER n 3012 de 21/11/2013. Referência: 99923.000436/2013-87 Assunto: Recurso à CGU contra acesso decisão denegatória de acesso à informação. Brasília, DF, 21.nov.2013. Disponível em $<$ http://www.acessoainformacao.gov.br/assuntos/recursos/recursos-a-cgu/arquivos/ministeriodas-comunicacoes/ect/pa30122013.pdf/view>. Acesso em 11.out.2015.

Controladoria-Geral da União. Relatório de Avaliação de Integridade em

Empresas Estatais n 201503942 - Empresa Brasileira de Correios e Telégrafos. Brasília, DF, Setembro/2015b. Disponível em $<$ http://sistemas.cgu.gov.br/relats/uploads/7804_\%20ECT\%20$\% 20$ Avalia $\%$ C3\%A7\%C3\%A3o\%20de\%20Integridade\%20$\% 20$ Relat $\%$ C3\%B3rio\%20Final.pdf>. Acesso em 20.out.2016

Decreto ${ }^{\circ} 1.904$, de 13 de maio de 1996. Institui o Programa Nacional de Direitos Humanos - PNDH (revogado). Diário Oficial [da] União, Brasília, DF, de 16.mai.1996 -. Disponível em < http://www.planalto.gov.br/ccivil_03/decreto/d1904.htm>. Acesso em 05.nov.2015.

Decreto $\mathrm{n}^{\mathrm{0}} 7.724$, de 16 de maio de 2012. Regulamenta a Lei no 12.527 , de 18 de novembro de 2011. Diário Oficial [da] União, Brasília, DF, de 16.mai.2012 - Edição extra e retificado em 18.5.2012. Disponível em <http://www.planalto.gov.br/ccivil_03/_ato20112014/2012/decreto/d7724.htm $\geq$. Acesso em 05.nov.2014.

Decreto $\mathrm{n}^{\mathrm{o}} 7.845$, de 14 de novembro de 2012. Regulamenta procedimentos para credenciamento de segurança e tratamento de informação classificada em qualquer grau de sigilo, e dispõe sobre o Núcleo de Segurança e Credenciamento. Diário Oficial [da] União, Brasília, DF, de 16.nov.2012. Disponível em $<$ http://www.planalto.gov.br/ccivil_03/decreto/2002/D7845.htm>. Acesso em 30.jan.2015;

Decreto $n^{\circ} 8.243$, de 23 de maio de 2014. Institui a Política Nacional de Participação Social - PNPS e o Sistema Nacional de Participação Social - SNPS, e dá outras providências. . Diário Oficial [da] União, Brasília, DF, de 26.maio.2014. Disponível em < http://www.planalto.gov.br/ccivil_03/_Ato2011-2014/2014/Decreto/D8243.htm>. Acesso em 06.nov.2016;

Decreto ${ }^{0}$ 75.657, de 24 de abril de 1975. Dispõe sobre o Sistema de Serviços Gerais dos órgãos civis da Administração Federal direta e das Autarquias federais e dá outras providências. (Revogado) Diário Oficial [da] União, Brasília, DF, de 25.abr.1975. Disponível em < http://www.planalto.gov.br/ccivil_03/decreto/1970-1979/D75657.htm>. Acesso em 06.nov.2016; 
Decreto $\mathrm{n}^{\circ} 79.099$, de 6 de janeiro de 1977. Aprova o Regulamento para Salvaguarda de Assuntos Sigilosos. (Revogado) Diário Oficial [da] União, Brasília, DF, de 7.jan.1977. Disponível em < https://www.planalto.gov.br/ccivil_03/decreto/1970-1979/D79099.htm>. Acesso em 06.nov.2016;

. Decreto-Lei no 200, de 25 de fevereiro de 1967. Dispõe sobre a organização da Administração Federal, estabelece diretrizes para a Reforma Administrativa e dá outras providências. Diário Oficial [da] União, Brasília, DF, de 27.fev.1967, retificado em 8.mar.1967, retificado em 30.mar.1967 e retificado em 17.jul.1967. Disponível em $<$ http://www.planalto.gov.br/ccivil_03/decreto-lei/Del0200.htm>. Acesso em 20.jun.2015.

Decreto-Lei no 509, de 20 de março de 1969. Dispõe sobre a transformação do Departamento dos Correios e Telégrafos em empresa pública, e dá outras providências. Diário Oficial [da] União, Brasília, DF, de 21.mar.1969 e retificado em 25.mar.1969 http://www.planalto.gov.br/ccivil_03/decreto-Lei/De10509.htm>. Acesso em 20.jun.2015.

Decreto-Lei no 900, de 29 de setembro de 1969. Altera disposições do Decreto-lei número 200, de 25 de fevereiro de 1967, e dá outras providências. Diário Oficial [da] União, Brasília, DF, de 39.set.1969. Disponível em <https://www.planalto.gov.br/ccivil_03/DecretoLei/Del0900.htm>. Acesso em 20.jun.2015.

Decreto-Lei $\mathrm{n}^{\mathrm{o}}$ 2.299, de 21 de novembro de 1986. Altera disposições do Decreto-lei número 200, de 25 de fevereiro de 1967, e dá outras providências. Diário Oficial [da] União, Brasília, DF, de 24.nov.186 retificado em 27.jul.1987. Disponível em $<$ http://www.planalto.gov.br/ccivil_03/decreto-lei/Del2299.htm>. Acesso em 20.jun.2015.

Dicionário brasileiro de terminologia arquivística. Rio de Janeiro: Arquivo Nacional, 2005. 232p.; 30cm. - Publicações Técnicas; $n^{\circ}$ 51. Disponível em $<$ http://www.conarq.arquivonacional.gov.br/images/publicacoes_textos/dicionrio_de_termino logia_arquivistica.pdf $>$. Acesso em 15.out.2016.

Empresa Brasileira de Correios e Telégrafos/ECT. Sobre Correios, A empresa, História. História Postal. Disponível em $<\mathrm{http}$ ://www.correios.com.br/sobre-correios/aempresa/historia>. Acesso em 20.jun.2015

. Empresa Brasileira de Correios e Telégrafos/ECT. Relatório/VIPAD-009/2011, REDIR-033/2011. Brasília, DF, de 15.jan.2011, p. 13-17. Anexo II da Dissertação.

. Lei ${ }^{0}$ 6.538, de 22 de junho de 1978. Lei Postal. Diário Oficial [da] União, Brasília, $\overline{\mathrm{DF}}$, de 23. jun. 1978. Disponível em <http://www.planalto.gov.br/ccivil_03/leis/L6538.htm>. Acesso em: 02.jun.2015.

. Lei $\mathrm{n}^{\circ}$ 6.404, de 15 de dezembro de 1976. Dispõe sobre as Sociedades por Ações. Diário Oficial [da] União, Brasília, DF, de 17.dez.1976 (suplemento). Disponível em < https://www.planalto.gov.br/ccivil_03/Leis/L6404consol.htm>. Acesso em: 02.jun.2015

Lei $\mathrm{n}^{\mathrm{o}} 7.596$, de 10 de abril de 1987. Altera dispositivos do Decreto-lei $\mathrm{n}^{\mathrm{o}} 200$, de 25 de fevereiro de 1967, modificado pelo Decreto-lei $\mathrm{n}^{\circ}$ 900, de 29 de setembro de 1969, e pelo Decreto-lei $n^{0} 2.299$, de 21 de novembro de 1986, e dá outras providências. Diário Oficial 
[da] União, Brasília, DF, de 11.abr.1987 (suplemento). Disponível em < http://www.planalto.gov.br/ccivil_03/leis/L7596.htm>. Acesso em: 02.jun.2015

. Lei ${ }^{\circ}$ 8.159, de 8 de janeiro de 1991. Lei de Política Nacional de Arquivos Públicos e Privados. Diário Oficial [da] União, Brasília, DF, de 9.jan.1991 e retificado em 28.jan.1991. Disponível em < http://www.planalto.gov.br/ccivil_03/leis/L8159.htm>. Acesso em: 02.jun.2015.

Lei $\mathrm{n}^{\mathrm{o}}$ 8.666, de 21 de junho de 1993. Regulamenta o art. 37, inciso XXI, da Constituição Federal, institui normas para licitações e contratos da Administração Pública e dá outras providências. Diário Oficial [da] União, Brasília, DF, de 22.jun.1993, republicado em 6.jul.1994 e retificado em 6.jul.1994. Disponível em $<$ http://www.planalto.gov.br/ccivil_03/leis/L8666cons.htm>. Acesso em: 02.jun.2015.

Lei n ${ }^{\circ} 9.784$, de 29 de janeiro de 1999. Regula o processo administrativo no âmbito da Administração Pública Federal. Diário Oficial [da] União, Brasília, DF, de e 1.fev.1999 e retificado em 11.mar.1999. Disponível em $<$ http://www.planalto.gov.br/ccivil_03/Leis/L9784.htm>. Acesso em: 02.jun.2015.

. Lei n ${ }^{0} 12.527$, de 18 de novembro de 2011. Lei de Acesso à Informação. Diário Oficial [da] União, Brasília, DF, 18 nov. 2011c. Disponível em $<$ http://www.planalto.gov.br/ccivil_03/_ato2011-2014/2011/lei/112527.htm>. Acesso em: 02.jun.2015.

. Lei $\mathrm{n}^{\circ} 12.490$, de 16 de setembro de 2011. Altera artigos do Decreto-Lei 509/1967 e outros. Diário Oficial [da] União, Brasília, DF, de 19.set.2011. Disponível em http://www.planalto.gov.br/ccivil_03/_Ato2011-2014/2011/Lei/L12490.htm. Acesso em: 02.jun.2015.

. Lei ${ }^{\circ} 12.813$, de 16 de maio de 2013. Lei de Conflito de Interesses. Diário Oficial [da] União, Brasília, DF, 17.mai. 2013 retificado 20.05.2013. Disponível em < http://www.planalto.gov.br/ccivil_03/_Ato2011-2014/2013/Lei/L12813.htm>. Acesso em: 22.set.2016.

Lei ${ }^{\circ} 12.846$, de $1^{\circ}$ de agosto de 2013. Lei Anticorrupção, dispõe sobre a responsabilização administrativa e civil de pessoas jurídicas pela prática de atos contra a administração pública, nacional ou estrangeira, e dá outras providências. Diário Oficial [da] União, Brasília, DF, 02.ago.2013. Disponível em < http://www.planalto.gov.br/ccivil_03/_Ato2011-2014/2013/Lei/L12846.htm>. Acesso em: 06.nov.2016.

. Lei $\mathrm{n}^{\mathrm{o}}$ 13.303, de 30 de junho de 2016. Lei de Responsabilidade das Estatais. Diário Oficial [da] União, Brasília, DF, $1^{\circ}$.jul.2016. Disponível em < http://www.planalto.gov.br/ccivil_03/_Ato2015-2018/2016/Lei/L13303.htm>. Acesso em: 22.set.2016.

. Lei Complementar $\mathrm{n}^{\circ} 101$, de 4 de maio de 2000. Estabelece normas de finanças públicas voltadas para a responsabilidade na gestão fiscal e dá outras providências. Diário Oficial [da] União, Brasília, DF, 5.mai.2000. Disponível em $<$ http://www.planalto.gov.br/ccivil_03/leis/LCP/Lcp101.htm>. Acesso em: 22.set.2016. 
. Lei Complementar $n^{\circ} 103$, de 14 de julho de 2000. Autoriza os Estados e o Distrito Federal a instituir o piso salarial a que se refere o inciso V do art. $7^{\circ}$ da Constituição Federal, por aplicação do disposto no parágrafo único do seu art. 22. Diário Oficial [da] União, Brasília, DF, 17.jul.2000. Disponível em $<$ https://www.planalto.gov.br/ccivil_03/Leis/LCP/Lcp103.htm>. Acesso em: 22.set.2016.

Lei Complementar $\mathrm{n}^{\circ} 131$, de 27 de maio de 2009. Acrescenta dispositivos à Lei Complementar $\mathrm{n}^{\mathrm{0}} 101$, de 4 de maio de 2000, que estabelece normas de finanças públicas voltadas para a responsabilidade na gestão fiscal e dá outras providências, a fim de determinar a disponibilização, em tempo real, de informações pormenorizadas sobre a execução orçamentária e financeira da União, dos Estados, do Distrito Federal e dos Municípios. Diário Oficial [da] União, Brasília, DF, 28.mai.2009. Disponível em $<$ https://www.planalto.gov.br/ccivil_03/leis/LCP/Lcp131.htm>. Acesso em: 22.set.2016.

Mensagem $n^{\circ} 58$, de 22 de outubro de 2003. Solicita retirada do Projeto de Lei $n^{\circ}$ 1491, de 1999. Presidência da República. Brasília, DF. Disponível em $<$ http://www.camara.gov.br/proposicoesWeb/prop_mostrarintegra?codteor $=433349 \&$ filename $=$ Tramitacao-MSC+558/2003+\%3D\%3E+PL+1491/1999>. Acesso em 15.out.2016

Ministério do Planejamento, Desenvolvimento e Gestão. Empresas Estatais

Federais Dirigentes/Endereços, abril/2016. Ministério do Planejamento Desenvolvimento e Gestão - Brasília: MP/SE/DEST, 2016. 22 páginas. Disponível em $<$ http://www.planejamento.gov.br/secretarias/upload/Arquivos/dest/empresas_estatais/160414 _emp_est_end_tel.pdf>. Acesso em 15.out.2016

Portaria Interministerial $n^{0} 233$, de 25 de maio de 2012. Disciplina, no âmbito do Poder Executivo federal, o modo de divulgação da remuneração e subsídio recebidos por ocupante de cargo, posto, graduação, função e emprego público, incluindo auxílios, ajudas de custo, jetons e quaisquer outras vantagens pecuniárias, bem como proventos de aposentadoria e pensões daqueles que estiverem na ativa, conforme disposto no inciso VI do $\S 3^{\circ}$ do art. $7^{\circ}$ do Decreto no 7.724, de 16 de maio de 2012. Diário Oficial [da] União, Brasília, DF, 28.mai.2012 Disponível em

$<$ https://conlegis.planejamento.gov.br/conlegis/legislacao/atoNormativoDetalhesPub.htm?id= 8987>. Acesso em 15.out.2016.

Presidência da República. Correios inauguram Serviço de Informações ao Cidadão. Portal Brasil. Brasília, DF: 2012a, publicado 14/05/2012 19h16, última modificação: 28/07/2014. Disponível em <http://www.brasil.gov.br/cidadania-e-justica/2012/05/correiosinauguram-servico-de-informacoes-ao-cidadao $>$. Acesso em 15.out.2016

Presidência da República. Lei de Acesso à Informação e Governo. Portal do Planalto. Brasília, DF: 2012b, publicado 31/07/2012 00h00, última modificação07/07/2014 12h25. Disponível em $<\mathrm{http}: / / \mathrm{www} 2$.planalto.gov.br/acompanhe-o-planalto/cadernodestaques/julho-2012/acesso-a-informacao-e-transparencia > . Acesso em 15.out.2016.

\section{Supremo Tribunal Federal. Arguição de Descumprimento de Preceito}

Fundamental - 46 -7 - Distrito Federal - ADPF 46/DF. Relator: Min. Marco Aurélio, Relator para o Acordão: Min ErosGrau. DJe no 35. Divulgação 25/02/2010. Data de publicação: 26/02/2010. Disponível em 
$<$ http://redir.stf.jus.br/paginadorpub/paginador.jsp?docTP=AC\&docID=608504 $>$. Acesso em 22.set.2015.

Supremo Tribunal Federal. Recurso extraordinário n. 589.998-PI. Relator: Min. Ricardo Lewandowski. Data de publicação: DJE 12/09/2013 - Ata n. 131/2013. DJE n. 179. Disponível em:

$<$ http://redir.stf.jus.br/paginadorpub/paginador.jsp?docTP=TP\&docID=4499353 $>$ Acesso em: 13 out. 2016.

BRESSER-PEREIRA, Luiz Carlos Bresser. Da administração pública burocrática à gerencial. Revista do Serviço Público. Ano 47, Volume 121º, Número I, Jan-Abr 1996.

BRESSER-PEREIRA, Luiz Carlos Bresser. Uma reforma gerencial da Administração Pública no Brasil. Revista do Serviço Público. Brasília: ENAP. Ano 49, Número 1 Jan-Mar 1998

BROOKES, B.C. The foundations of information Science: part I philosophical aspects. Journal of Information Science, n.2, p.125-133, 1980.

CARTA CAPITAL. Senado aprova impeachment e destitui Dilma. Carta Capital. Editora Confiança Ltda, São Paulo, 31.ago.2016. Disponível em

$<$ http://www.cartacapital.com.br/politica/senado-aprova-impeachment-e-afasta-dilmadefinitivamente>. Acesso em 15.set.2016

CARVALHÊDO, Shirley do Prado; RODRIGUES, Georgete Medleg. A política de informação orgânica no regime militar brasileiro: os arquivos da Guerrilha do Araguaia (1972-1974). Resumo de pôster apresentado ao GT-05 - Política e Economia da Informação, IX ENANCIB, USP, São Paulo, 2008. Disponível em < file://C:/Users/A/Downloads/30615332-2-PB\%20(1).pdf >. Acesso em 09.04.2016.

CEPIK, Marco A.C. Espionagem e democracia: agilidade e transparência como dilemas na institucionalização de serviços de inteligência. Rio de Janeiro: FGV, 2003. Disponível em $<$ http://professor.ufrgs.br/marcocepik/files/cepik___2003_-_fgv_-

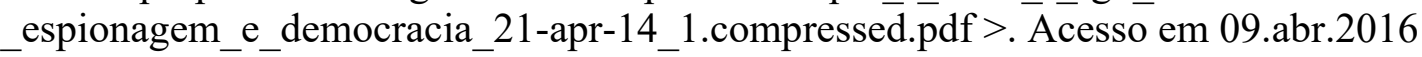

CHAGAS, Eduardo F. O Método Dialético de Marx: Investigação e exposição crítica do objeto. Síntese - Revista de Filosofia. Belo Horizonte, v. 38, nº 120, p. 55-70, 2011.

Disponível em

$<$ http://www.ifch.unicamp.br/formulario_cemarx/selecao/2012/trabalhos/6520_Chagas_Eduar do.pdf $>$.

CRESWELL, John W. Projeto de pesquisa: métodos qualitativo, quantitativo e misto. 3. ed. Porto Alegre, RS: Artmed, 2010. 296p.

CUNHA FILHO, Marcio Camargo; XAVIER, Vitor César Silva. Lei de Acesso à informação: teoria e prática. - Rio de Janeiro: Lumen Juris, 2014. 439p.

CURY, Vania Maria. História da Industrialização no Século XIX (Séries Didáticos). Rio de Janeiro, RJ. Editora UFRJ, 2006. 
DAGNINO, R. A capacitação de gestores públicos: uma aproximação ao problema sob a ótica da administração política. In: Revista Brasileira de Administração Política. Escola de Administração da Universidade Federal da Bahia. N. 10, vol. 6, 1 de abril de 2013. Disponível em $<$ http://www.rebap.ufba.br/view.php?id=49>. Acesso em 27.set.2015.

DAGNINO. Renato; COSTA, Greiner (org.). Gestão Estratégica em Políticas Públicas. Campinas, SP: Editora Alínea, 2013.

DECLARAÇÃO DOS DIREITOS DOS HOMENS E DOS CIDADÃOS, França, 1789. Disponível em:

$<$ http://pt.wikipedia.org/wiki/Declara\%C3\%A7\%C3\%A3o_dos_Direitos_do_Homem_e_do_ Cidad\%C3\%A3o > . Acesso em 09.jun.2015.

DECLARAÇÃO UNIVERSAL DOS DIREITOS HUMANOS. Adotada e proclamada pela Resolução n 217 A (III) da Assembleia Geral das Nações Unidas, em 10 de dezembro de 1948. Assinada pelo Brasil na mesma data.

$<$ http://www.direitoshumanos.usp.br/index.php/Declara\%C3\%A7\%C3\%A3o-Universal-dosDireitos-Humanos/declaracao-universal-dos-direitos-humanos.html >. Acesso em 09.jun.2015.

DINIZ, Mariana. Na véspera do julgamento pelo Senado, Dilma diz que há um golpe em andamento. Agência Brasil-EBC, Brasília, 25.ago.2016. Disponível em

$<$ http://agenciabrasil.ebc.com.br/politica/noticia/2016-08/na-vespera-do-julgamento-pelosenado-dilma-diz-que-ha-um-golpe-andameno-no>. Acesso em 15.set.2016

ENGELS, Friedrich. A Origem da Família, da Propriedade Privada e do Estado. Coleção Perspectivas do Homem. Vol. 99. Série Ciências Sociais. Tradução Leandro Konder. Rio de Janeiro: Editora Civilização Brasileira S.A., 1974.

FELIPPE, Igor. Um horizonte sombrio com o conservadorismo do Congresso: redução da maioridade é o $1^{\circ}$ ato. Carta Maior, São Paulo, 27.mar.2015. Disponível em $<$ http://cartamaior.com.br/?/Editoria/Politica/Um-horizonte-sombrio-com-o-conservadorismodo-Congressoreducao-da-maioridade-e-o-1\%25BA-ato/4/33146>. Acesso em 15.set.2016

FERNANDES, Ananda Simões. A perseguição além da fronteira: os órgãos de repressão e espionagem da ditadura brasileira para o controle dos exilados brasileiros no Uruguai.

ESTUDIOS HISTORICOS - CDHRP- mayo 2009 - No 1 - ISSN: 1688 - 5317. Disponível em $<$ http://www.estudioshistoricos.org/edicion_1/ananda-simoes.pdf $>$ Acesso em 01.nov. 2015

FONSECA, Maria Odila. Arquivologia e Ciência da Informação. Rio de Janeiro: Editora FGV, 8 impressão - 2013.

FREIRE, Paulo. Educação e Mudança. Coleção Educação e Mudança, vol. 1. Rio de Janeiro: Paz e Terra, 1983.

FROHMANN, Bernd. O caráter social, material e público da informação. Tradução: Laffayette de Souza Álvares Junior; Revisão teórico-conceitual: Lidia Silva de Freitas; Revisão de Tradução: Ricardo Sili da Silva. In: FUJITA, M.S.L.; MARTELETO, R.M.; LARA, M.L.G. (Org.) A dimensão epistemológica da Ciência da Informação e suas interfaces 
técnicas, políticas e institucionais nos processos de produção, acesso e disseminação da informação. São Paulo: Cultura Acadêmica, 2008

GERHARDT, Tatiana Engel e SILVEIRA, Denise Tolfo / [organizado por]; Métodos de pesquisa. Coordenado pela Universidade Aberta do Brasil - UAB/UFRGS e pelo Curso de Graduação Tecnológica - Planejamento e Gestão para o Desenvolvimento Rural da SEAD/UFRGS. - Porto Alegre: Editora da UFRGS, 2009.

GHANI, Alan. Por que George Soros financia movimentos de esquerda? Entenda.

InfoMoney com Bloomberg. Blog publicado em 26.ago.2016. Disponível em $<\mathrm{http}$ //www.infomoney.com.br/blogs/economia-e-politica/economia-e-politica-direto-aoponto/post/5476997/por-que-george-soros-financia-movimentos-esquerda-entenda $>$. Acesso em 22.nov.2016

GIDDENS, Anthony. O Estado-nação e a Violência. Segundo Volume de uma Crítica Contemporânea ao Materialismo Histórico. São Paulo: Edusp, 2001.

GLEICK, James. A Informação: Uma história, uma teoria, uma enxurrada. Tradução Augusto Calil. São Paulo: Companhia das Letras, 2013.

GRAMSCI, A. Introdução à Filosofia da Práxis. Lisboa: Editora Antídoto, 1979.

GRIGOLETO, Maria Cristina. Informação e Documento: expressão material no patrimônio. InCID: R. Ci. Inf. e Doc., Ribeirão Preto, v. 3, n.1, p. 57-69, jan./jun. 2012. Disponível em $<$ http://www.revistas.usp.br/incid/article/view/42369>. Acesso em 28.out.2016

JARDIM, José Maria. A LEI DE ACESSO À INFORMAÇÃO PÚBLICA: dimensões político-Informacionais. Tendências da Pesquisa Brasileira em Ciência da Informação, v.5, n.1, 2012. Disponível em:

$<$ http://inseer.ibict.br/ancib/index.php/tpbci/article/view/68/110 >. Acesso em 24.mai.2015.

JARDIM, José Maria. Transparência e Opacidade do estado no Brasil: usos e desusos da informação governamental. Niterói: Editora UFF,1999.

JESSOP, Bob. O ESTADO, O PODER, O SOCIALISMO DE POULANTZAS COMO UM CLÁSSICO MODERNO. Tradução: Gustavo Biscaia de Lacerda. Revisão da

Tradução: Álvaro Bianchi. Rev. Sociol. Polít., Curitiba, v. 17, n. 33, p. 131-144, jun. 2009. Disponível em < http://www.scielo.br/pdf/rsocp/v17n33/v17n33a10.pdf $>$. Acesso em 28.out.2016

JUNQUILHO; G.; LEITE-DA-SILVA, A. Carta de Valores versus Carta de Intenções: uma reflexão sobre a abordagem integrativa da dimensão cultural em organizações. Organização \& Sociedade. V.11. No. 31 - Setembro/Dezembro, 2004. Disponível em $<$ http://www.scielo.br/pdf/osoc/v11n31/08.pdf>. Acesso em 30.nov.2016

KEHL, Maria Rita. Os crimes do Estado se repetem como farsa. 2013. IN Folha de São Paulo - <http://www1.folha.uol.com.br/ilustrissima/1250962-os-crimes-do-estado-serepetem-como-farsa.shtml $>$. Acesso em 27.set.2015 
KLERING, L R; PORSSE, M. C. S.; GUADAGNIN, L. A.. Novos Caminhos da Administração Pública Brasileira. Revista Análise, Porto Alegre, v.21, n.1, p. 4-17, jan/jun.2010. Disponível em < http://www.tre-

rs.gov.br/arquivos/KLERING_Novos_CaminhosADM.pdf>. Acesso em 26.out.2016

LEITE, Paulo Moreira. A Outra História do Mensalão: as contradições de um julgamento político. São Paulo: Geração Editorial, 2013.

LEONEL, Liliane Dutra; CRUZ, Valquíria Araújo. A Estruturação de procedimentos de gestão documental e mudança de paradigmas: o caso dos Correios do Brasil. Revista ACTAS. Congresso Nacional de Bibliotecárias, Arquivistas e Documentalistas. Associação Portuguesa Bibliotecárias, Arquivistas e Documentalistas. Portugal, Évora, $\mathrm{n}^{\mathrm{o}}$ 12, 2015. Disponível em < http://www.bad.pt/publicacoes/index.php/congressosbad/article/view/1387>. Acesso em 12.out.2016.

LOPES, Janaina Vedoin; KONRAD, Glaucia Vieira Ramos. Arquivos da Repressão e Leis de Acesso à Informação: os casos brasileiro e argentino na construção do direito à memória e à verdade. Aedos no 13 vol. 5 - Ago/Dez 2013.

MACARINI, P.J. Governo Geisel: Transição Político-Econômica? Um Ensaio de Revisão. Revista Econômica Contemporânea, Rio de Janeiro, v. 15, n. 1, p. 30-61, jan-abr/2011. Disponível em <http://www.scielo.br/pdf/rec/v15n1/a02v15n1.pdf.> Acesso em 18.set.2016

MANDEL, Ernest. Introdução ao Marxismo. Porto Alegre, RS. Editora Movimento, 1982.

MARX, K. Crítica ao Programa de Gotha (1875). Fonte Digital Rocket Edition de 1999.Disponível em < http://www.ebooksbrasil.org/adobeebook/gotha.pdf > . Acesso em 11.out.2015.

MARX, K.; ENGELS, F. A ideologia alemã: Feuerbach, a oposição entre as concepções materialista e idealista. São Paulo: Martin Claret, 2006. Disponível em < https://www.marxists.org/portugues/marx/1845/ideologia-alema-oe/>. Acesso em 11.out.2015.

MARX, K., ENGELS, F. Manifesto do Partido Comunista. RocketEdition de 1999. Fonte Digital. Edição Eletrônica: Ed. Ridendo Castigat Mores. Disponível em

$<$ http://www.ebooksbrasil.org/adobeebook/manifestocomunista.pdf > . Acesso em 10.out.2015

MENDEL, Toby. Liberdade de Informação: um estudo de direito comparado, $2^{\text {a }}$ edição, revisada e atualizada. Brasília: UNESCO, 2009. Disponível em

$<$ http://portal.unesco.org/ci/en/files/26159/126398551119freedom_information_pt.pdf/freedo m_information_pt.pdf $>$. Acesso em 05.mai.2015

MIRANDA, Roberto Campos da Rocha. Informações Estratégicas, Estudo de Caso Aplicado à ECT. Brasília, 1999. Disponível em $<$ http://repositorio.unb.br/bitstream/10482/5488/5/1999\%20

Roberto\%20Campos\%20da\%20Rocha\%20Miranda.pdf>. Acesso em 16.abr.2015.

NOGUEIRA, Marco Aurélio. Um Estado para a Sociedade Civil: tema éticos e políticos da gestão democrática. São Paulo: Cortez, $3^{\mathrm{a}}$ edição, 2011. 
OLIVEIRA, Dalgiza Andrade. As Questões Éticas da Democratização da Informação.

Tendências da Pesquisa Brasileira em Ciência da Informação 6.1 (2013). Disponível em $<$ http://inseer.ibict.br/ancib/index.php/tpbci/article/viewFile/91/144>

OLIVEIRA, Eliane Braga de. O CONCEITO DE MEMÓRIA NA CIÊNCIA DA INFORMAÇÃO NO BRASIL: uma análise da produção cientifica dos programas de pós-graduação. 2010. 196f. Tese (Doutorado em Ciência da Informação) - Faculdade de Ciência da Informação da UnB, Brasília, 2010.

OPEN KNOWLEDGE BRASIL. Global Open Data Index 2015. Disponível em $<$ http://index.okfn.org/place/> . Acesso em 20.nov.2016.

PEREIRA, Eliete. Guia de Fontes Acesso à Informação Pública. Organização das Nações Unidas para a Educação, a Ciência e a Cultura (UNESCO). Disponível em $<$ http://www.cge.pr.gov.br/arquivos/File/Transparencia_e_Acesso_a_Informacao/guiafonte.p df $>$

PIRES, José Calixto de Souza Pires e MACÊDO, Kátia Barbosa. Cultura Organizacional em Organizações Públicas no Brasil. Revista de Administração Pública. Rio de Janeiro 40(1):81105, Jan./Fev. 2006.

PORTO JR, Rubem. Exposição/Palestra Censura Postal, 1917 a 1930. São Paulo, SP. 28.set.2014. Disponível em

$<$ http://www.sppaulista.com.br/newsdesk_info.php?newsdesk_id=569\%3E.> Acesso em 10.jan.2016

REIS, Ligia Maria de Souza Lopes. A Lei Brasileira de Acesso à Informação e a Construção da Cultura de Transparência no Brasil: Os Desafios para a Implementação da Norma e o Agir Comunicativo no Enfrentamento da Opacidade Estatal. Repositório Institucional UnB. Disponível em $<$ http://repositorio.unb.br/bitstream/10482/16262/1/2014_LigiaMariadeSouzaLopesReis.pdf > Acesso em 20.ago.2016.

RODRIGUES, Georgete Medleg. Indicadores de "transparência ativa" em instituições públicas: análise dos portais de universidades públicas federais. Liinc em Revista, Rio de Janeiro, v.9, n.2, p. 423-438, nov.2013. Disponível em <http://www.ibict.br/lii>.

ROUSSEFF, Dilma. Discurso da Presidenta da República na abertura da $1^{\text {a }}$ Conferência de Alto Nível de Parceria para Governo Aberto (OGP), publicado 17/04/2012, 13h23, última modificação 04/07/2014 20h10. Disponível em <http://www2.planalto.gov.br/acompanhe-oplanalto/discursos/discursos-da-presidenta/discurso-da-presidenta-da-republica-dilmarousseff-na-abertura-da-1 a-conferencia-de-alto-nivel-parceria-para-governo-aberto-ogpbrasilia-df>. Acesso em 15.jan.2016.

SÁ, Maria Irene da Fonseca e; MALIN, Ana Maria Barcellos. LEI DE ACESSO A INFORMAÇÃO UM ESTUDO COMPARATIVO COM OUTROS PAÍSES. XIII

Encontro Nacional de Pesquisa em Ciência da Informação - XIII ENANCIB 2012. Disponível em <http://enancib.ibict.br/index.php/enancib/xiiienancib/paper/viewFile/3776/2899> 
SANTINI, Daniel. Por que o CEP deve ser tratado como informação pública? Código Urbano. Publicado em 12.mar.2015. Disponível em $<$ http://codigourbano.org/por-que-o-cep-deve-sertratado-como-informacao-publica/>. Acesso em 15.out.2016

SARACEVIC, T. Ciência da Informação: origem, evolução e relações. Perspectivas em Ciência da Informação, Belo Horizonte, v. 1, n. 1, p. 41-62, jan./jul.1996. Disponível em: $<$ http://portaldeperiodicos.eci.ufmg.br/index.php/pci/article/view/235/22 > . Acesso em: 27.abr.2015.

SCHEIN, Edgar H. Organizational culture and leadership - The Jossey-Bass business \& management series. San Francisco, CA, USA: 3rd ed. - 2004. Disponível em $<$ http://www.untagsmd.ac.id/files/Perpustakaan_Digital_2/ORGANIZATIONAL\%20CULTURE\%20Organizati onal $\% 20$ Culture $\% 20$ and $\% 20$ Leadership, $\% 203$ rd\%20Edition.pdf>. Acesso em 30.nov.2016

SILVA, Mauricio Roberto da; PIRES, Giovani De Lorenzi; PEREIRA, Rogerio Santos (Editores). O ASSALTO À DEMOCRACIA, GOLPE E “JOGO SUJO” E "JOGO CADA VEZ MAIS SUJO” NA “REPUBLIQUETA DAS BANANAS”: O Brasil não é sério!. Editorial da Revista Motrivivência. V.28, n.47, p. 6 - 13, maio/16. Disponível em $<$ https://periodicos.ufsc.br/index.php/motrivivencia/article/viewFile/21758042.2016v28n47p6/31813>

TAVARES, Maria da Conceição. Política e economia na formação do Brasil. Revista Teoria e Debate. São Paulo: Edição 44 - Abril, 2000. Disponível em $<$ http://www.teoriaedebate.org.br/?q=materias/economia/politica-e-economia-na-formacaodo-brasil>. Acesso em 10.jan.2016

TEIXEIRA, Tadeu G. Os correios em transformação: reestruturação, organização do trabalho e políticas de gestão do trabalho (1994-2011). Tese (doutorado em ciências sociais) - Instituto de Filosofia e Ciências Humanas, Universidade Estadual de Campinas, 2013. Disponível em Biblioteca Digital da Unicamp

$<$ http://www.bibliotecadigital.unicamp.br/document/?code $=000918292 \& \mathrm{fd}=\mathrm{y}>$. Acesso em 24.mai.2015.

UNIVERSIDADE DE SÃO PAULO. Sistema Integrado de Bibliotecas da USP. Diretrizes para apresentação de dissertações e teses da USP: documento eletrônico e impresso Parte I (ABNT) / Sistema Integrado de Bibliotecas da USP; Vânia Martins Bueno de Oliveira Funaro, coordenadora [et al.] . - 2. ed. rev. ampl. - São Paulo: Sistema Integrado de Bibliotecas da USP, 2009. 102 p. (Cadernos de Estudos; 9)

VIEIRA, Isabela. Lei de Acesso à Informação "pegou", avaliam especialistas. Agência Brasil - EBC, Rio de Janeiro, 21.ago.2014, 19h15. Disponível em

$<$ http://agenciabrasil.ebc.com.br/direitos-humanos/noticia/2014-08/lei-de-acesso-informacaopegou-avaliam-especialistas $>$. Acesso em 15.out.2016

WERSIG, Gernot; NEVELING, Ulrich. R. The phenomena of Interesting to Information Science. Information Scientist, v.9, n4, p.127-140. Dec. 1975. 
ZEPEDA, Jesús Rodríguez. Estado y transparência: um paseo por la filosofia política. Cuadernos de transparência $n^{\circ}$ 4. Mexico: Instituto Federal de Acesso a la Infomación y Protección de Datos (IFAI), Octava impresion, septiembre 2012. Disponível em $<$ http://inicio.inai.org.mx/Publicaciones/cuadernillo4.pdf $>$. Acesso em 12.out.2015

ZORZAL, Luiza. Transparência das Informações das Universidades Federais: Estudo dos Relatórios de Gestão à Luz dos Princípios de Boa Governança na Administração Pública Federal. 2015.199 f. Dissertação (Mestrado em Ciência da Informação) - Faculdade de Ciência da Informação, Universidade de Brasília, DF, 2015. 


\section{APÊNDICE}

Apêndice A - Questionário Pré-teste

Prezada Colega, peço sua colaboração em realizar o pré-teste no questionário enviado que servirá de coleta de dados para minha dissertação de Mestrado pela sua atuação como Ponto Focal do SIC. Aguardo um retorno o mais breve possível, pois pretendo enviá-lo aos demais ainda esta semana. Te agradeço muito pelo apoio.

Universidade de Brasília

Faculdade de Ciência da Informação

Programa de Pós-Graduação em Ciência da Informação - Mestrado em Ciência da Informação Profa. Dra. Eliane Braga (Orientadora)

\section{Prezados Colegas,}

Este questionário é parte de minha dissertação de Mestrado em Ciência da Informação na Universidade de Brasília, como bolsista de Pós-Graduação da ECT, e solicito sua colaboração respondendo as questões suscitadas no questionário a seguir. Solicito o envio com as respostas até o dia 1\%05/2016.

A presente pesquisa tem por objetivo a verificação do processo de atendimento a Lei de Acesso à Informação a partir da análise de requisitos quanto a percepção da estrutura da empresa e da Organização da Informação nos Correios.

Este questionário é para ser respondido por servidores dos Correios que atuam e/ou atuaram como Pontos Focais do SIC desde sua implantação em maio de 2012.

Universo de respondentes do questionário:

Administração Central: entre 30 a 50 pessoas

Regionais: entre 10 a 30 pessoas

Total: máximo 80 pessoas

Observação-1:

Para responder aos itens relacionados a partir do Bloco 3 considere os Elementos

Característicos:

Suporte - material sobre o qual as informações são registradas (papel, CD, pendrive, etc)

Forma - estágio de como se encontram os documentos (disponível, em meio físico, digital) Formato - configuração física que assume o documento, de acordo com natureza do suporte e o modo como foi confeccionado (livro, caderno, cartaz, planta, gravura)

Espécie - configuração que assume um documento de acordo com a disposição e a natureza das informações nele contidas (relatório, ata, boletim, certidão, declaração, atestado, memorando, oficio)

Aluna: Ana Maria de Almeida Ribeiro 
Foi convidado a preencher o formulário Questionário Pesquisa

Mestrado_PPGCI/UNB_AnaMRibeiro . Para o preencher, vá a:

https://docs.google.com/forms/d/1TK1m1cnWl-

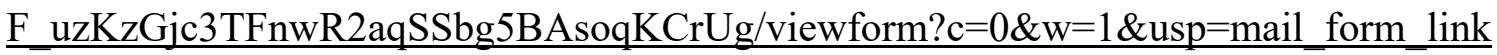

O presente Pré-Teste não apresentou indicação de modificações por parte dos respondentes e portanto, a formatação final encontra-se no APÊNDICE B. 
Apêndice B - Questionário aplicado nos Pontos Focais do SIC-ECT

\section{Questionário Pesquisa \\ Mestrado_PPGCI/UNB_AnaMRibeiro}

Universidade de Brasília

Faculdade de Ciência da Informação

Programa de Pós-Graduação em Ciência da Informação - Mestrado em Ciência da Informação Profa.

Dra. Eliane Braga (Orientadora)

Prezados Colegas,

Este questionário é parte de minha dissertação de Mestrado em Ciência da Informação na Universidade de Brasília, como bolsista de Pós-Graduação dos Correios, e solicito sua colaboração respondendo as questões suscitadas no questionário a seguir. Solicito o envio com as respostas até o dia 20/05/2016.

A presente pesquisa tem por objetivo a verificação do processo de atendimento a Lei de Acesso à Informação a partir da análise de requisitos quanto a percepção da estrutura da empresa e da Organização da Informação nos Correios.

Este questionário é para ser respondido por servidores dos Correios que atuam e/ou atuaram como Pontos Focais do SIC desde sua implantação em maio de 2012.

Universo de respondentes do questionário:

Administração Central: entre 30 a 50 pessoas

Regionais: entre 10 a 30 pessoas

Total: máximo 80 pessoas

Observação-1:

Para responder aos itens relacionados a partir do Bloco 3 considere os Elementos Característicos:

Suporte - material sobre o qual as informações são registradas (papel, CD, pendrive, etc)

Forma - estágio de como se encontram os documentos (disponível, em meio físico, digital)

Formato - configuração física que assume o documento, de acordo com natureza do suporte e o modo como foi confeccionado (livro, caderno, cartaz, planta, gravura)

Espécie - configuração que assume um documento de acordo com a disposição e a natureza das informações nele contidas (relatório, ata, boletim, certidão, declaração, atestado, memorando, oficio)

Aluna: Ana Maria de Almeida Ribeiro

*Obrigatório 
BLOCO 1 - Identificação do Servidor

Informações para determinar o perfil do Ponto Focal SIC

1. Nome completo (não será

divulgado na pesquisa):

2. Cargo nos Correios * Marcar apenas uma oval.

Agente de Correios

Técnico de Correios

Analista de Correios

3 Ano de ingresso nos Correios * Marcar apenas uma oval.

$\longrightarrow$ antes de 64

○ $1965-1970$

$\bigcirc 1971-1980$

○ $1981-1990$

$\longrightarrow 1991-2000$

$\longrightarrow 2001-2010$

$\longrightarrow$ depois de 2011

4. Função Técnica/Gerencial * Marcar apenas uma oval.
AC - Analistas [I - XIII]
AC - Chefe de Departamento
$\Longrightarrow$ AC - Gerente
$\Longrightarrow$ DR - Assessor
$\Longrightarrow$ DR - Gerente
$\Longrightarrow$ DR - Coordenador
$\longrightarrow$ Outra: 
5. Formação * Marcar apenas uma oval.

Educação Fundamental
Ensino Médio
Especialização
Mestrado
Doutorado

6. Ano de nascimento Marcar apenas uma oval.

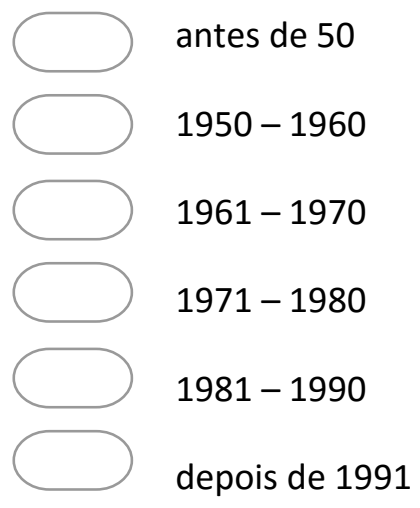

BLOCO 2 - Identificação da área de atuação

Neste bloco buscamos identificar as áreas de atuação dos Pontos Focais para análise dos demais blocos.

7 Identificação da área de atuação * Marcar apenas uma oval.

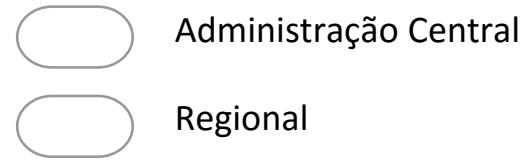

8. Área (Presidência/Vice-

Presidência/Departamento/Central/Gerência): 
9. Período que exerce (u) a atividade de Ponto Focal do SIC * Marcar apenas uma oval.
$\longrightarrow$ menos de 1 ano
$\bigcirc$ por 2 anos
por 3 anos
$\bigcirc$ mais de 3 anos
$\bigcirc$ Outra:

10. A atividade de Ponto Focal do SIC * Marcar apenas uma oval.
$\square$
não estou mais atuando com demandas do SIC
estou atuando com demandas do SIC

11. Ramo de atividade da área que atua * Marcar apenas uma oval.

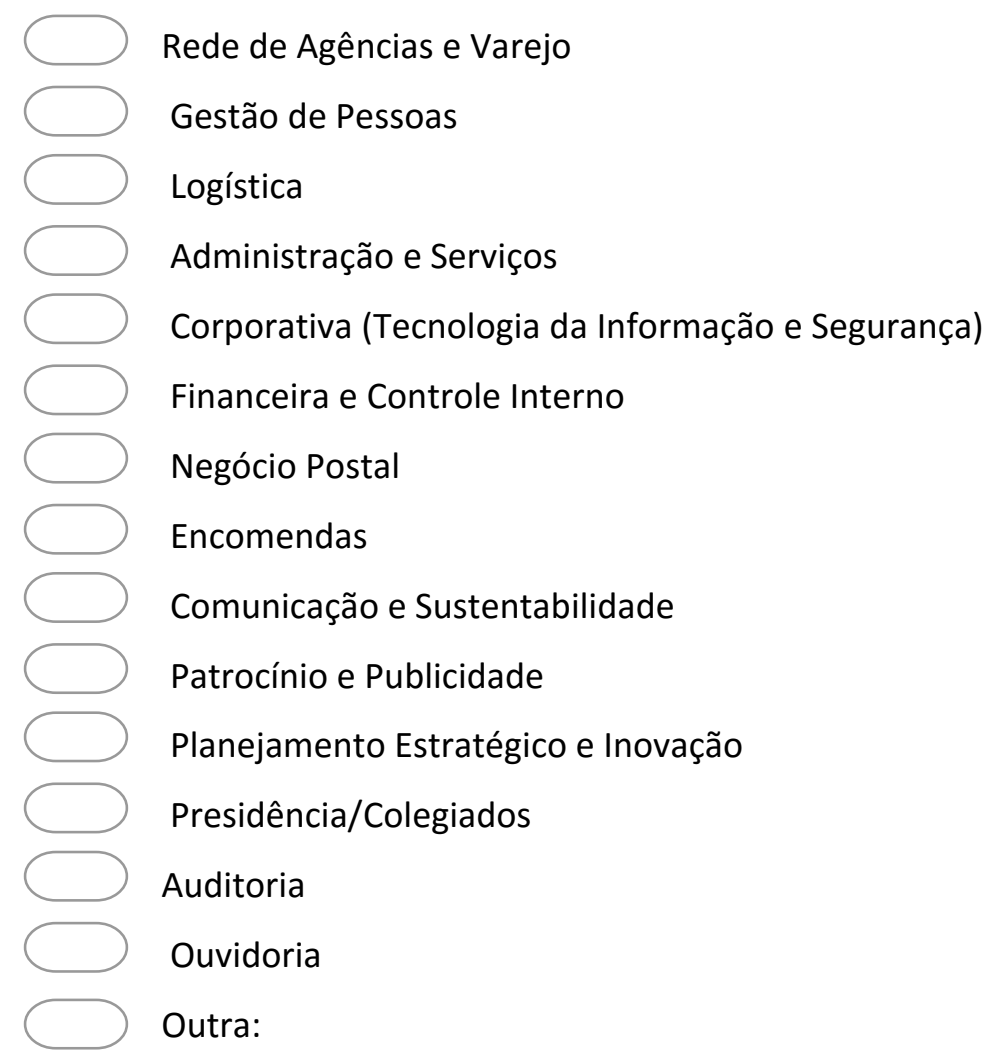

BLOCO 3 - Requisitos de Qualidade da Organização da Informação

Neste bloco as perguntas se referem à análise da informação com relação ao tempo, conteúdo, forma e localização da informação. 
12 A informação solicitada está disponibilizada quando recebo o pedido de informação * Marcar apenas uma oval.

$\Longrightarrow$ Discordo completamente

Discordo parcialmente

Nem discordo, nem concordo

Concordo parcialmente

Concordo completamente

Desconheço

13. A informação solicitada está atualizada quando recebo o pedido de informação * Marcar apenas uma oval.

$\Longrightarrow$ Discordo completamente

Discordo parcialmente

Nem discordo, nem concordo

Concordo parcialmente

Concordo completamente

Desconheço

14. A informação solicitada está disponibilizada sempre que é requerida * Marcar apenas uma oval.

$\Longrightarrow$ Discordo completamente

$\Longrightarrow$ Discordo parcialmente

Nem discordo, nem concordo

Concordo parcialmente

Concordo completamente

$\longrightarrow$ Desconheço 
15. A informação solicitada não contém erros e está em conformidade com as necessidades de informação dos cidadãos * Marcar apenas uma oval.

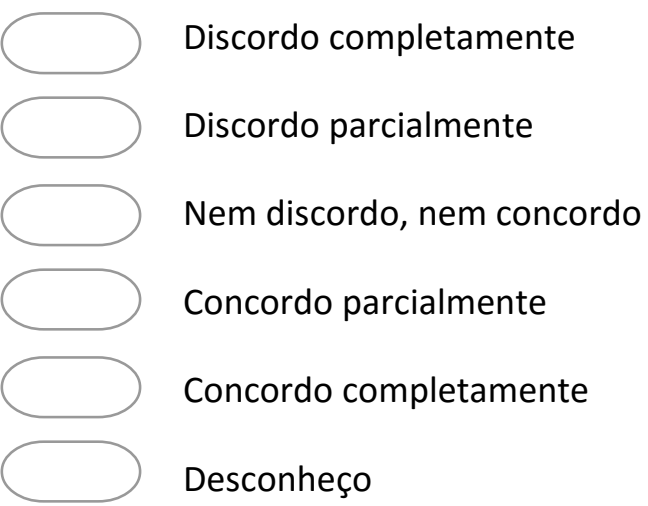

16 Toda a informação necessária está disponibilizada * Marcar apenas uma oval.

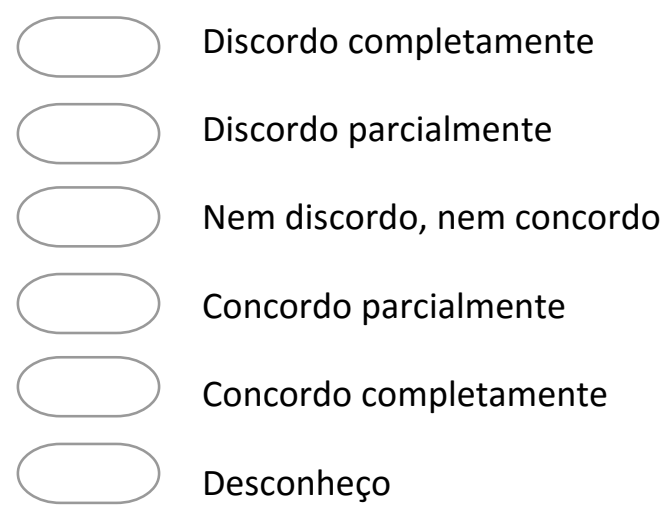

17. A informação solicitada pode ser organizada de modo específico ou geral, dependendo da demanda dos cidadãos * Marcar apenas uma oval.

Discordo completamente

Discordo parcialmente

Nem discordo, nem concordo

Concordo parcialmente

$\Longrightarrow$ Concordo completamente

Desconheço 
18. A informação solicitada está disponibilizada de uma forma clara e de fácil compreensão * Marcar apenas uma oval.

Discordo completamente

Discordo parcialmente

Nem discordo, nem concordo

Concordo parcialmente

Concordo completamente

Desconheço

19. A informação solicitada está disponibilizada na íntegra ou sintetizada, conforme a demanda dos cidadãos * Marcar apenas uma oval.

Discordo completamente

Discordo parcialmente

Nem discordo, nem concordo

Concordo parcialmente

Concordo completamente

$\longrightarrow$ Desconheço

20 A informação está disponibilizada em um formato que a torna inteligível e está de acordo com os requisitos de acesso dos cidadãos. * Marcar apenas uma oval.
$\Longrightarrow$ Discordo completamente
Discordo parcialmente
Nem discordo, nem concordo
Concordo parcialmente
Concordo completamente
Desconheço 
21. A informação está dispersa em diferentes espécies e é necessário produzir um novo documento, ou sistematizá-las, para disponibilizar a informação demandada. * Marcar apenas uma oval.
$\longrightarrow$
Discordo completamente
Discordo parcialmente
Nem discordo, nem concordo
Concordo parcialmente
Concordo completamente
Desconheço

22. A maior parte da informação solicitada está no arquivo corrente (documentos vigentes, em uso). *Marcar apenas uma oval.

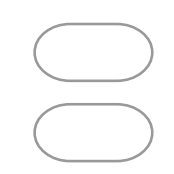
Discordo completamente
Discordo parcialmente
Nem discordo, nem concordo
$\Longrightarrow$ Concordo parcialmente
$\bigcirc$ Concordo completamente
$\bigcirc$ Desconheço

23. A maior parte da informação solicitada está no arquivo intermediário (final de vigência, aguardam prazos de prescrição e destinação final) * Marcar apenas uma oval.

Discordo completamente

Discordo parcialmente

Nem discordo, nem concordo

$\Longrightarrow$ Concordo parcialmente

$\Longrightarrow$ Concordo completamente

Desconheço 
24 A maior parte da informação solicitada está no arquivo permanente (sem vigência, mas providos de valor, não podem ser eliminados) * Marcar apenas uma oval.

Discordo completamente

Discordo parcialmente

Nem discordo, nem concordo

Concordo parcialmente

Concordo completamente

Desconheço

25. Algumas informações solicitadas não estão em arquivos, mas na memória oral de empregados antigos na empresa. * Marcar apenas uma oval.

Discordo completamente

Discordo parcialmente

Nem discordo, nem concordo

Concordo parcialmente

$C$ Concordo completamente

$\Longrightarrow$ Desconheço

26. Algumas informações solicitadas estão em sistemas eletrônicos que são consultados para produzir a resposta, sem a emissão de relatórios físicos. * Marcar apenas uma oval.

Discordo completamente

Discordo parcialmente

Nem discordo, nem concordo

Concordo parcialmente

Concordo completamente

Desconheço 
27. Algumas informações solicitadas não estão arquivadas e foram eliminadas por políticas de qualidade total antes de 2011 * Marcar apenas uma oval.

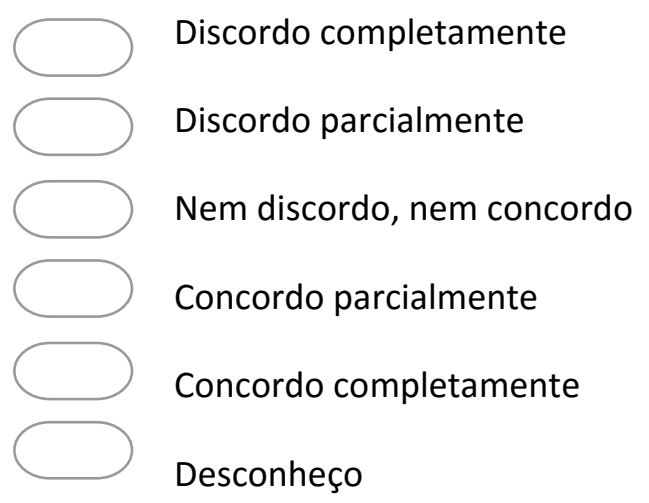

BLOCO 4 - Requisitos de Política de Gestão, Segurança e Transparência da Informação As respostas devem se ater à área de atuação do servidor como Ponto Focal do SIC

28 A mudança de sistemática de gestão documental a partir de 2011 (NUP, GDC, Protocolo) facilitou a recuperação dos documentos. * Marcar apenas uma oval.

Discordo completamente

Discordo parcialmente

Nem discordo, nem concordo

Concordo parcialmente

$\Longrightarrow$ Concordo completamente

Desconheço 
29. O NDA (Núcleo de Documentação e Arquivo) é um aliado importante na localização dos documentos e processos.. * Marcar apenas uma oval.

Discordo completamente

$\longrightarrow$ Discordo parcialmente

Nem discordo, nem concordo

Concordo parcialmente

Concordo completamente

$\Longrightarrow$ Desconheço

30. Tenho dificuldade em localizar documentos pelo NDA uma vez que a digitalização como imagem não me permite uma busca individualizada de documentos. * Marcar apenas uma oval.

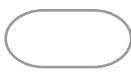

Discordo completamente

Discordo parcialmente

Nem discordo, nem concordo

Concordo parcialmente

Concordo completamente

Desconheço

31. O GDC (Gestão de Documentos Correntes) é um sistema que contribui na localização dos processos na empresa. * Marcar apenas uma oval.

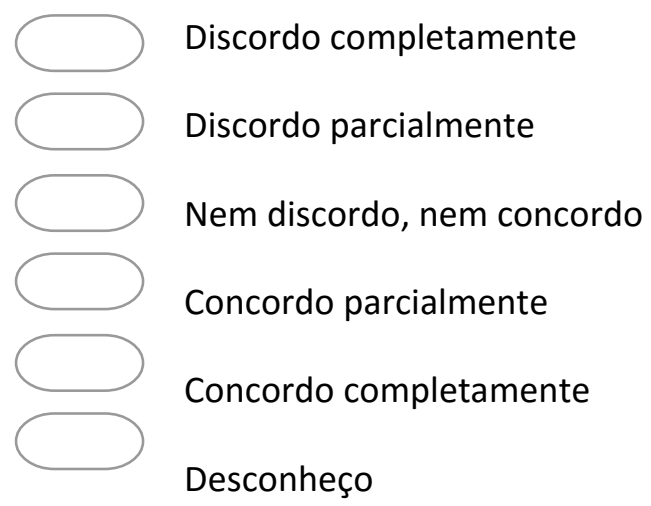


32. Há dificuldades em localizar documentos com origem anterior à 10(dez) anos atrás. * Marcar apenas uma oval.

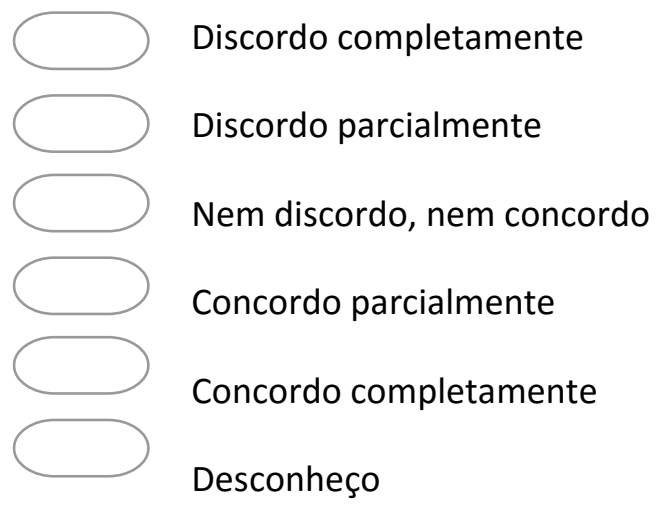

33. Na abertura de NUPs, e/ou criação de qualquer documento o assunto é informado corretamente o que possibilita localizar processos de assuntos relacionados. * Marcar apenas uma oval.

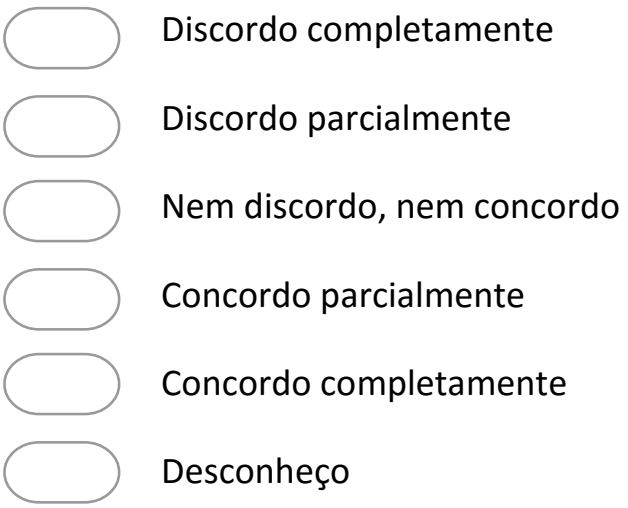

34. Na abertura de NUPs, e/ou criação de qualquer documento no GDC, o código de classificação do assunto dos documentos e processos está identificado o que contribui para o correto arquivamento e seu tempo de guarda. * Marcar apenas uma oval.

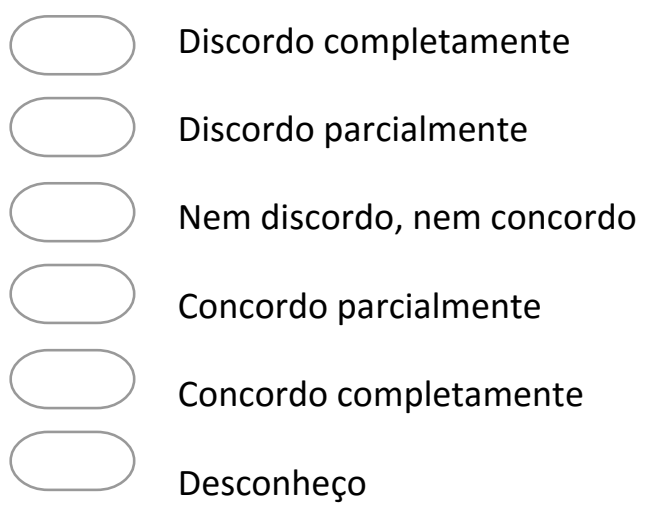


35. Conheço a atual política de preservação e eliminação de documentos da empresa. * Marcar apenas uma oval.

Discordo completamente

Discordo parcialmente

$\Longrightarrow$ Nem discordo, nem concordo

$\Longrightarrow$ Concordo parcialmente

$\Longrightarrow$ Concordo completamente

$\Longrightarrow$ Desconheço

36 A área, como decorrência da Lei de Acesso à Informação, implementou política de gestão de informação. * Marcar apenas uma oval.

Discordo completamente

Discordo parcialmente

Nem discordo, nem concordo

Concordo parcialmente

Concordo completamente

$\longrightarrow$ Desconheço

37. A área determinou procedimentos documentados de Proteção e Controle de Informações Sigilosas/Acesso Restrito. * Marcar apenas uma oval.

Discordo completamente

Discordo parcialmente

Nem discordo, nem concordo

Concordo parcialmente

$\Longrightarrow$ Concordo completamente

$\square$ Desconheço 
38. Houve modificação no entendimento da área acerca de informações que antes eram consideradas sigilosas e, a partir da LAl, passaram a ser públicas. * Marcar apenas uma oval.

Discordo completamente

Discordo parcialmente

Nem discordo, nem concordo

Concordo parcialmente

Concordo completamente

Desconheço

39. Houve atualização nos manuais da área (normas e procedimentos) em função da LAI * Marcar apenas uma oval.

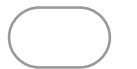

Discordo completamente

Discordo parcialmente

Nem discordo, nem concordo

Concordo parcialmente

Concordo completamente

Desconheço

$40 \mathrm{~A}$ área definiu procedimentos internos para o tratamento e transporte de documentos classificados como de Acesso Restrito e/ou Sigilosos que em suporte digital deverá ser transmitida por meio da Internet ou da Rede Corporativa dos Correios, utilizando Virtual Private Network (VPN), criptografia ou certificação digital (MANTIC 5/8 - Anexo 2 - 5.9). * Marcar apenas uma oval.
$\longrightarrow$
Discordo completamente
Discordo parcialmente
Nem discordo, nem concordo
Concordo parcialmente
Concordo completamente
Desconheço 
41. A área tem política de Gestão do Conhecimento * Marcar apenas uma oval.

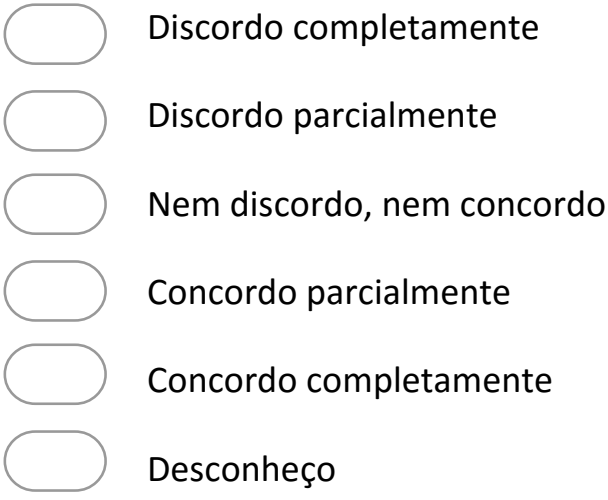

42. A área criou uma rotina para identificação de informações de amplo interesse público para a publicação em transparência ativa * Marcar apenas uma oval.
$\longrightarrow$ Discordo completamente
Discordo parcialmente
Nem discordo, nem concordo
Concordo parcialmente
$\Longrightarrow$ Concordo completamente
$\Longrightarrow$ Desconheço

43. A área tomou por base os pedidos mais recorrentes/frequentes para incrementar a Seção de Acesso à Informação no sítio dos Correios * Marcar apenas uma oval.

Discordo completamente

Discordo parcialmente

Nem discordo, nem concordo

Concordo parcialmente

Concordo completamente

Desconheço 
44 A área possui rotina de atualização de suas informações na Seção de Acesso à Informação no sítio dos Correios. * Marcar apenas uma oval.

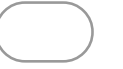

Discordo completamente

Discordo parcialmente

Nem discordo, nem concordo

Concordo parcialmente

$C$ Concordo completamente

$\longrightarrow$ Desconheço

45. A área promoveu a sensibilização dos servidores em exercício quanto aos seus deveres frente ao direito de acesso à informação do cidadão * Marcar apenas uma oval.

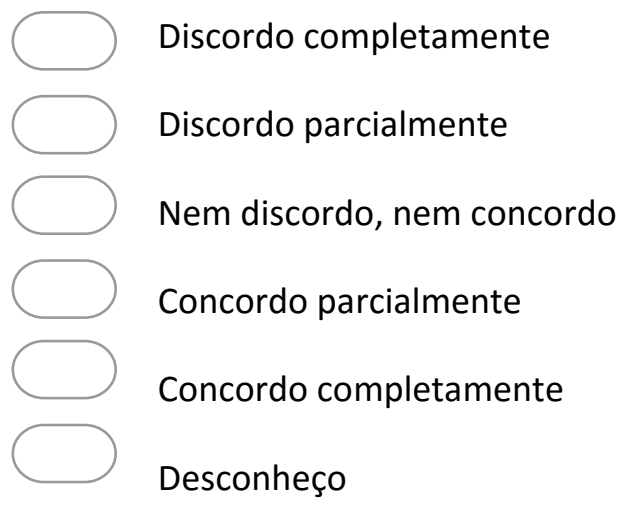

BLOCO 5 - Requisitos para disponibilização da informação

Este bloco trata de sua opinião sobre a disponibilização da informação

46. Os Correios é empresa pública e por isso deve ter transparência nas suas informações. * Marcar apenas uma oval.

Discordo completamente

Discordo parcialmente

Nem discordo, nem concordo

Concordo parcialmente

Concordo completamente

Desconheço 
47. Os Correios, em que pese ser uma empresa pública, atua no âmbito concorrencial e essas informações devem ser restrita à alguns gestores. * Marcar apenas uma oval.

Discordo completamente

Discordo parcialmente

Nem discordo, nem concordo

Concordo parcialmente

Concordo completamente

$\Longrightarrow$ Desconheço

48 Uma empresa pública de direito privado, que atua no mercado competitivo, não pode ter suas informações públicas. * Marcar apenas uma oval.

Discordo completamente

Discordo parcialmente

Nem discordo, nem concordo

Concordo parcialmente

Concordo completamente

$\Longrightarrow$ Desconheço

49. O monopólio postal previsto na Constituição Federal determina o compromisso público com a sociedade brasileira, e esta deve ter acesso a todas as informações da empresa. * Marcar apenas uma oval.

Discordo completamente

Discordo parcialmente

Nem discordo, nem concordo

Concordo parcialmente

Concordo completamente

$\longrightarrow$ Desconheço 
50. Os Correios deveriam ter autonomia e independência de qualquer órgão e decidir o que deve ou não ser disponibilizado * Marcar apenas uma oval.
Discordo completamente
Discordo parcialmente
Nem discordo, nem concordo
Concordo parcialmente
Concordo completamente
Desconheço

Com tecnologia

Google Forms 
Apêndice C - Resposta do Questionário

\section{5 respostas}

Publicar estatísticas

Resumo

BLOCO 1 - Identificação do Servidor

1. Nome completo (não será divulgado na pesquisa):

2. Cargo nos Correios

Agente de Correios 12,9

Técnico de Correios 5 14,3

Analista de Correios 2982,9

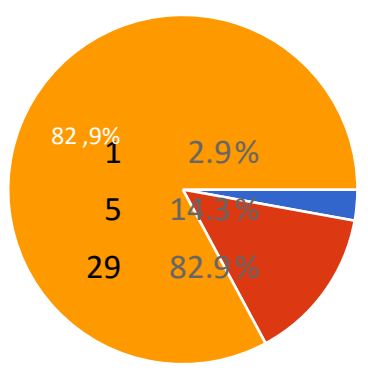

3. Ano de ingresso nos Correios

$\begin{array}{crr}\text { antes de } 64 & 0 & 0 \% \\ 1965-1970 & 0 & 0 \% \\ 1971-1980 & 9 & 25.7 \% \\ 1981-1990 & 5 & 14.3 \% \\ 1991-2000 & 8 & 22.9 \% \\ 2001-2010 & 10 & 28.6 \% \\ \text { depois de } 2011 & 3 & 8.6 \%\end{array}$

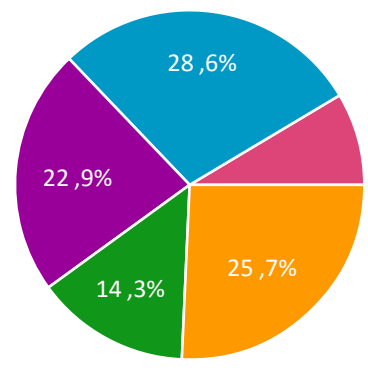

4. Função Técnica/Gerencial

$\begin{array}{rrr}\text { AC - Analistas [ I - XIII] } & 18 & 51.4 \% \\ \text { AC - Chefe de Departamento } & 2 & 5.7 \% \\ \text { AC - Gerente } & 6 & 17.1 \% \\ \text { DR - Assessor } & 4 & 11.4 \% \\ \text { DR - Gerente } & 0 & 0 \% \\ \text { DR - Coordenador } & 1 & 2.9 \% \\ \text { Outro } & 4 & 11.4 \%\end{array}$

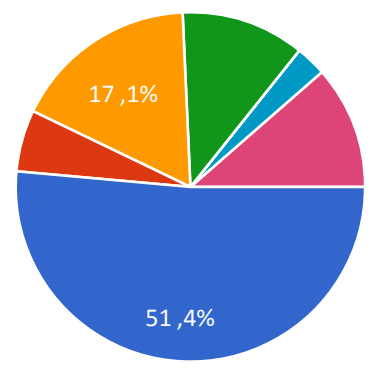


5. Formação

$\begin{array}{rrr}\text { Educação Fundamental } & 0 & 0 \% \\ \text { Ensino Médio } & 0 & 0 \% \\ \text { Graduação } & 7 & 20 \% \\ \text { Especialização } & 25 & 71.4 \% \\ \text { Mestrado } & 3 & 8.6 \% \\ \text { Doutorado } & 0 & 0 \%\end{array}$

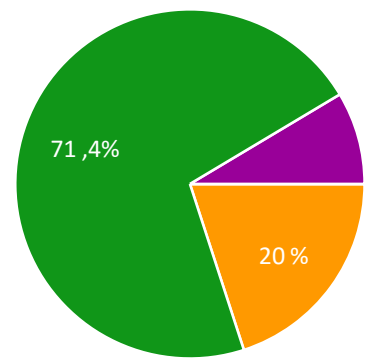

6. Ano de nascimento

$\begin{array}{rrr}\text { antes de } 50 & 1 & 2.9 \% \\ 1950-1960 & 10 & 28.6 \% \\ 1961-1970 & 11 & 31.4 \% \\ 1971-1980 & 12 & 34.3 \% \\ 1981-1990 & 1 & 2.9 \% \\ \text { depois de 1991 } & 0 & 0 \%\end{array}$

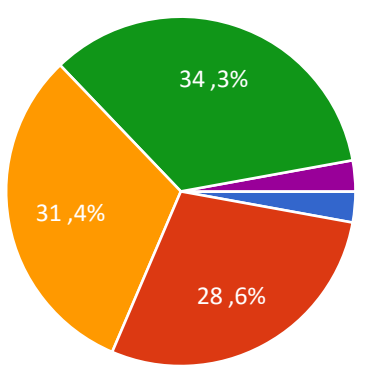

BLOCO 2 - Identificação da área de atuação

7. Identificação da área de atuação

Administração Central $30 \quad 85.7 \%$

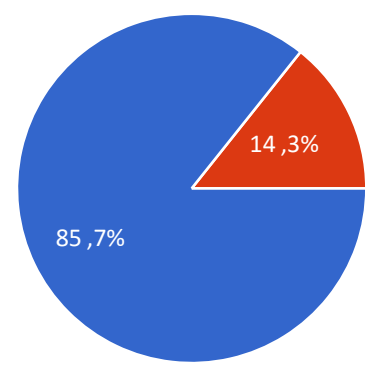

Regional $5 \quad 14.3 \%$

8. Área (Presidência/Vice-Presidência/Departamento/Central/Gerência):

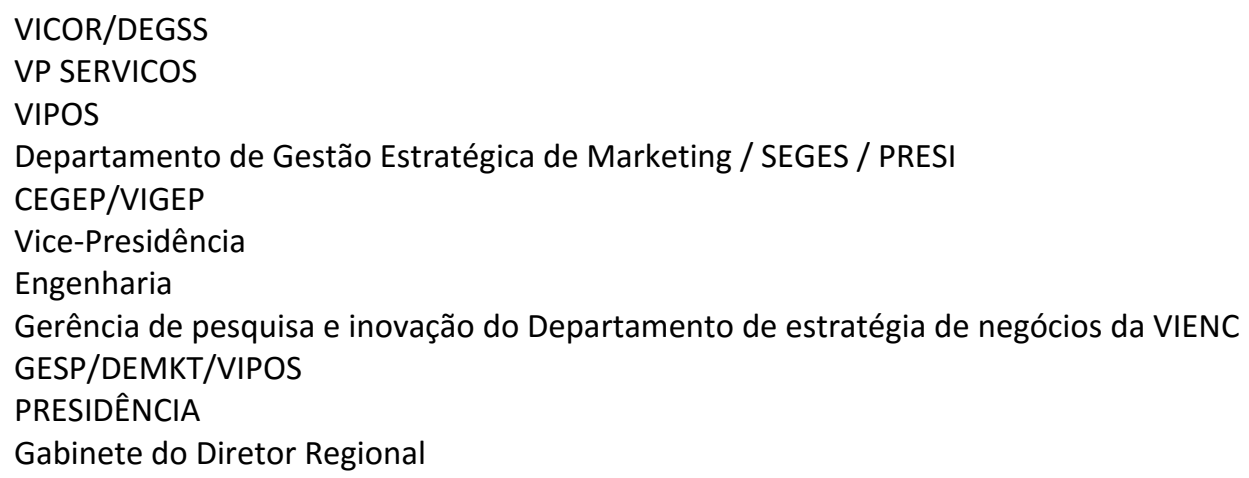


CENTRAL

VISER

AUDITORIA

VISER/CEREL

Gerência

VICOR

VICE-PRESIDÊNCIA (VICOR)

VIFIC/DECON

Vice-Presidência

PRESI/DERIN/GRES

VISER/DENGE

/GCPI DERIN -

ASCOM

PRESI/DPLAN/GPLA

AC/VICOR/DEGOR/GRSN

VISER/DESAO/GAB

Conselho de Administração/Ouvidoria/Gerência de Análise de Informações

Presidência

Assessoria Técnica Diretoria Regional de São Paulo Metroplitana

VICE-PRESIDÊNCIA DE FINANÇAS E CONTROLES INTERNOS

DECOE

DR/ASCOM

Vice-Presidência de Gestão de Pessoas/Central de Gestão de Pessoas/Gerência de Benefícios

DEGEC/GCUP

9. Período que exerce $(\mathrm{u})$ a atividade de Ponto Focal do SIC

menos de 1 ano $925.7 \%$

por 2 anos $1131.4 \%$

por 3 anos $25.7 \%$

mais de 3 anos 10 28.6\%

Outro $3 \quad 8.6 \%$

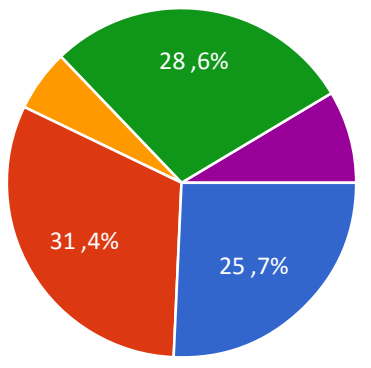


10. A atividade de Ponto Focal do SIC

não estou mais atuando com demandas do SIC

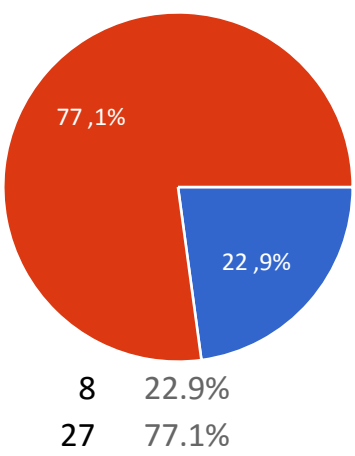

11. Ramo de atividade da área que atua

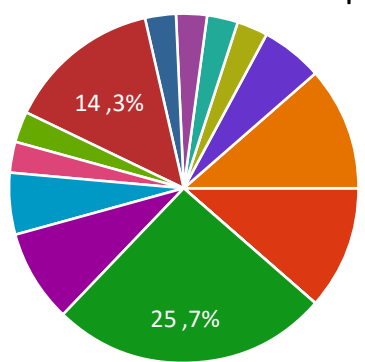

$$
\begin{array}{rcr}
\text { Rede de Agências e Varejo } & 0 & 0 \% \\
\text { Gestão de Pessoas } & 4 & 11.4 \% \\
\text { Logística } & 0 & 0 \% \\
\text { Administração e Serviços } & 9 & 25.7 \%
\end{array}
$$

Corporativa (Tecnologia da Informação e Segurança) 3 8.6\%

Financeira e Controle Interno $2 \quad 5.7 \%$

Negócio Postal $1 \quad 2.9 \%$

Encomendas $\quad 1 \quad 2.9 \%$

Comunicação e Sustentabilidade $514.3 \%$

Patrocínio e Publicidade 1 2.9\%

Planejamento Estratégico e Inovação $1 \quad 2.9 \%$

Presidência/Colegiados $1 \quad 2.9 \%$

Auditoria $1 \quad 2.9 \%$

Ouvidoria $2 \quad 5.7 \%$

Outro $4 \quad 11.4 \%$ 
BLOCO 3 - Requisitos de Qualidade da Organização da Informação

12.A informação solicitada está disponibilizada quando recebo o pedido de informação

$\begin{array}{rrr}\text { Discordo completamente } & 5 & 14.3 \% \\ \text { Discordo parcialmente } & 7 & 20 \% \\ \text { Nem discordo, nem concordo } & 3 & 8.6 \% \\ \text { Concordo parcialmente } & 17 & 48.6 \% \\ \text { Concordo completamente } & 3 & 8.6 \% \\ \text { Desconheço } & 0 & 0 \%\end{array}$

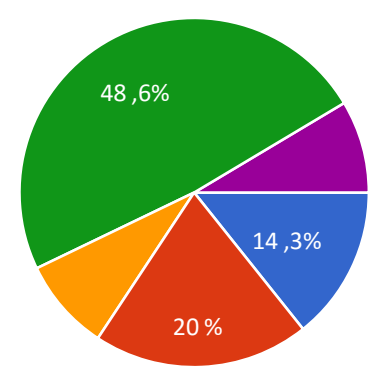

13.A informação solicitada está atualizada quando recebo o pedido de informação

$\begin{array}{rrr}\text { Discordo completamente } & 3 & 8.6 \% \\ \text { Discordo parcialmente } & 7 & 20 \% \\ \text { Nem discordo, nem concordo } & 4 & 11.4 \% \\ \text { Concordo parcialmente } & 16 & 45.7 \% \\ \text { Concordo completamente } & 5 & 14.3 \% \\ \text { Desconheço } & 0 & 0 \%\end{array}$

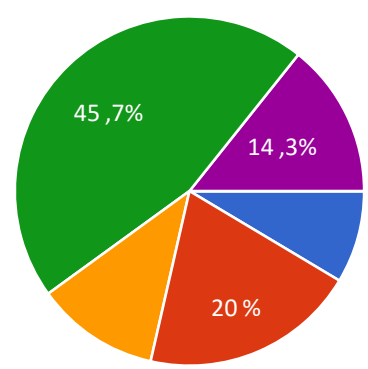

14.A informação solicitada está disponibilizada sempre que é requerida

$\begin{array}{rrr}\text { Discordo completamente } & 4 & 11.4 \% \\ \text { Discordo parcialmente } & 5 & 14.3 \% \\ \text { Nem discordo, nem concordo } & 5 & 14.3 \% \\ \text { Concordo parcialmente } & 14 & 40 \% \\ \text { Concordo completamente } & 7 & 20 \% \\ \text { Desconheço } & 0 & 0 \%\end{array}$

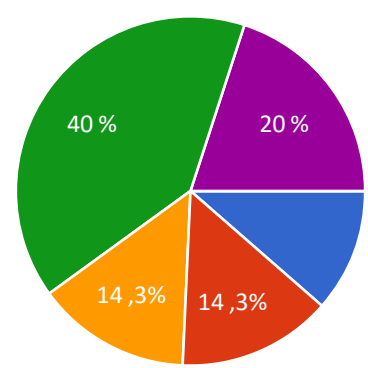


15.A informação solicitada não contém erros e está em conformidade com as necessidades de informação dos cidadãos

$\begin{array}{rrr}\text { Discordo completamente } & 0 & 0 \% \\ \text { Discordo parcialmente } & 9 & 25.7 \% \\ \text { Nem discordo, nem concordo } & 3 & 8.6 \% \\ \text { Concordo parcialmente } & 18 & 51.4 \% \\ \text { Concordo completamente } & 4 & 11.4 \% \\ \text { Desconheço } & 1 & 2.9 \%\end{array}$

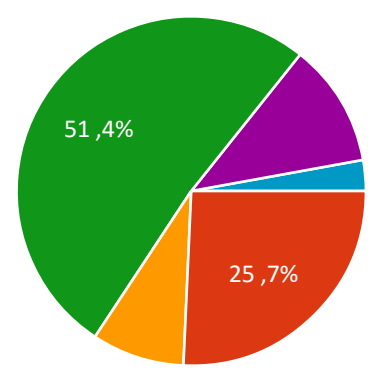

16.Toda a informação necessária está disponibilizada

$\begin{array}{rrr}\text { Discordo completamente } & 2 & 5.7 \% \\ \text { Discordo parcialmente } & 11 & 31.4 \% \\ \text { Nem discordo, nem concordo } & 3 & 8.6 \% \\ \text { Concordo parcialmente } & 16 & 45.7 \% \\ \text { Concordo completamente } & 2 & 5.7 \% \\ \text { Desconheço } & 1 & 2.9 \%\end{array}$

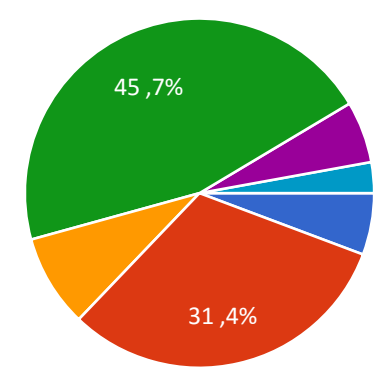

17.A informação solicitada pode ser organizada de modo específico ou geral, dependendo da demanda dos cidadãos

$\begin{array}{rrr}\text { Discordo completamente } & 0 & 0 \% \\ \text { Discordo parcialmente } & 3 & 8.6 \% \\ \text { Nem discordo, nem concordo } & 2 & 5.7 \% \\ \text { Concordo parcialmente } & 12 & 34.3 \% \\ \text { Concordo completamente } & 17 & 48.6 \% \\ \text { Desconheço } & 1 & 2.9 \%\end{array}$

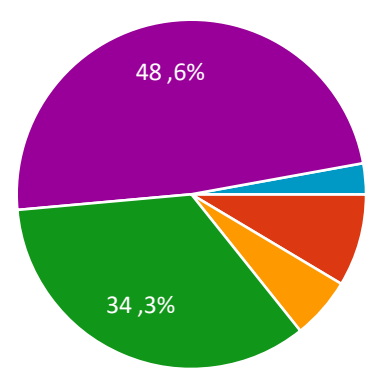


18.A informação solicitada está disponibilizada de uma forma clara e de fácil compreensão

$\begin{array}{rrr}\text { Discordo completamente } & 0 & 0 \% \\ \text { Discordo parcialmente } & 9 & 25.7 \% \\ \text { Nem discordo, nem concordo } & 1 & 2.9 \% \\ \text { Concordo parcialmente } & 17 & 48.6 \% \\ \text { Concordo completamente } & 7 & 20 \% \\ \text { Desconheço } & 1 & 2.9 \%\end{array}$

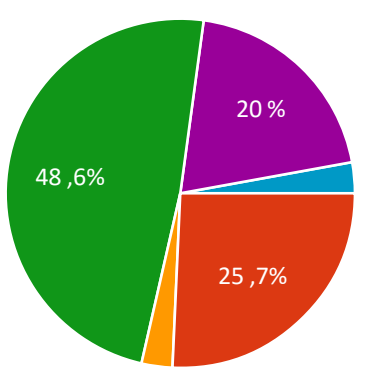

19.A informação solicitada está disponibilizada na íntegra ou sintetizada, conforme a demanda dos cidadãos

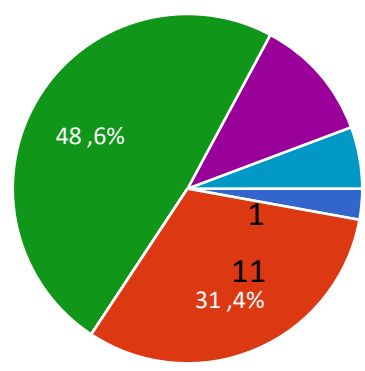

$\begin{array}{rrr}\text { Discordo completamente } & & 2.9 \% \\ \text { Discordo parcialmente } & & 31.4 \% \\ \text { Nem discordo, nem concordo } & 0 & 0 \% \\ \text { Concordo parcialmente } & 17 & 48.6 \% \\ \text { Concordo completamente } & 4 & 11.4 \% \\ \text { Desconheço } & 2 & 5.7 \%\end{array}$

20.A informação está disponibilizada em um formato que a torna inteligível e está de acordo com os requisitos de acesso dos cidadãos.

$\begin{array}{rrr}\text { Discordo completamente } & 0 & 0 \% \\ \text { Discordo parcialmente } & 10 & 28.6 \% \\ \text { Nem discordo, nem concordo } & 7 & 20 \% \\ \text { Concordo parcialmente } & 12 & 34.3 \% \\ \text { Concordo completamente } & 6 & 17.1 \% \\ \text { Desconheço } & 0 & 0 \%\end{array}$

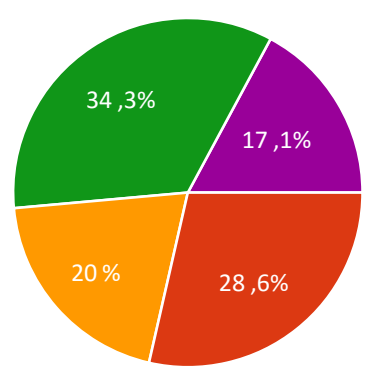


21.A informação está dispersa em diferentes espécies e é necessário produzir um novo documento, ou sistematizá-las, para disponibilizar a informação demandada.

$\begin{array}{rrr}\text { Discordo completamente } & 1 & 2.9 \% \\ \text { Discordo parcialmente } & 4 & 11.4 \% \\ \text { Nem discordo, nem concordo } & 1 & 2.9 \% \\ \text { Concordo parcialmente } & 20 & 57.1 \% \\ \text { Concordo completamente } & 8 & 22.9 \% \\ \text { Desconheço } & 1 & 2.9 \%\end{array}$

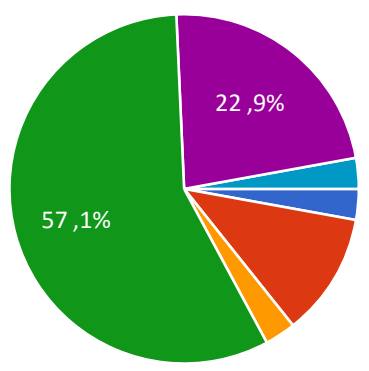

22.A maior parte da informação solicitada está no arquivo corrente (documentos vigentes, em uso).

$\begin{array}{rrr}\text { Discordo completamente } & 1 & 2.9 \% \\ \text { Discordo parcialmente } & 6 & 17.1 \% \\ \text { Nem discordo, nem concordo } & 3 & 8.6 \% \\ \text { Concordo parcialmente } & 18 & 51.4 \% \\ \text { Concordo completamente } & 6 & 17.1 \% \\ \text { Desconheço } & 1 & 2.9 \%\end{array}$

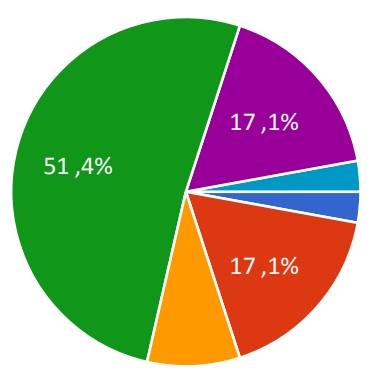

23.A maior parte da informação solicitada está no arquivo intermediário (final de vigência, aguardam prazos de prescrição e destinação final)

$\begin{array}{rrr}\text { Discordo completamente } & 4 & 11.4 \% \\ \text { Discordo parcialmente } & 6 & 17.1 \% \\ \text { Nem discordo, nem concordo } & 7 & 20 \% \\ \text { Concordo parcialmente } & 11 & 31.4 \% \\ \text { Concordo completamente } & 0 & 0 \% \\ \text { Desconheço } & 7 & 20 \%\end{array}$

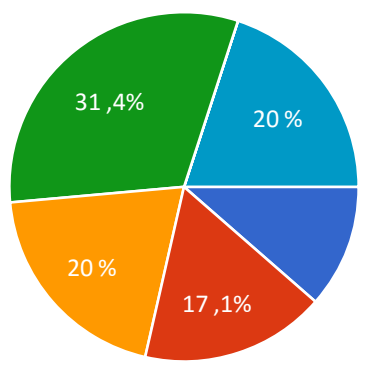


24.A maior parte da informação solicitada está no arquivo permanente (sem vigência, mas providos de valor, não podem ser eliminados)

$\begin{array}{rrr}\text { Discordo completamente } & 4 & 11.4 \% \\ \text { Discordo parcialmente } & 8 & 22.9 \% \\ \text { Nem discordo, nem concordo } & 9 & 25.7 \% \\ \text { Concordo parcialmente } & 8 & 22.9 \% \\ \text { Concordo completamente } & 4 & 11.4 \% \\ \text { Desconheço } & 2 & 5.7 \%\end{array}$

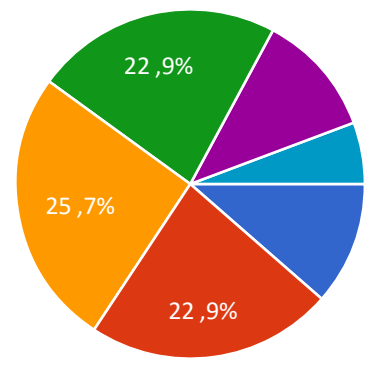

25 Algumas informações solicitadas não estão em arquivos, mas na memória oral de empregados antigos na empresa.

$\begin{array}{rrr}\text { Discordo completamente } & 8 & 22.9 \% \\ \text { Discordo parcialmente } & 8 & 22.9 \% \\ \text { Nem discordo, nem concordo } & 1 & 2.9 \% \\ \text { Concordo parcialmente } & 11 & 31.4 \% \\ \text { Concordo completamente } & 3 & 8.6 \% \\ \text { Desconheço } & 4 & 11.4 \%\end{array}$

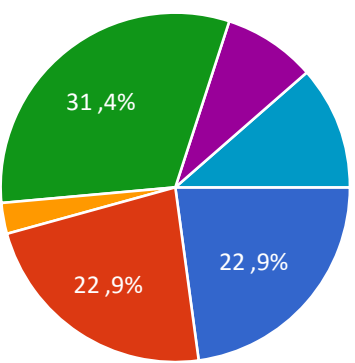

26 Algumas informações solicitadas estão em sistemas eletrônicos que são consultados para produzir a resposta, sem a emissão de relatórios físicos.

$\begin{array}{rrr}\text { Discordo completamente } & 1 & 2.9 \% \\ \text { Discordo parcialmente } & 7 & 20 \% \\ \text { Nem discordo, nem concordo } & 1 & 2.9 \% \\ \text { Concordo parcialmente } & 15 & 42.9 \% \\ \text { Concordo completamente } & 10 & 28.6 \% \\ \text { Desconheço } & 1 & 2.9 \%\end{array}$

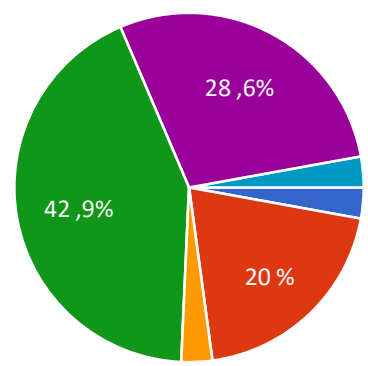


27 Algumas informações solicitadas não estão arquivadas e foram eliminadas por políticas de qualidade total antes de 2011

$\begin{array}{rrr}\text { Discordo completamente } & 4 & 11.4 \% \\ \text { Discordo parcialmente } & 6 & 17.1 \% \\ \text { Nem discordo, nem concordo } & 6 & 17.1 \% \\ \text { Concordo parcialmente } & 7 & 20 \% \\ \text { Concordo completamente } & 1 & 2.9 \% \\ \text { Desconheço } & 11 & 31.4 \%\end{array}$

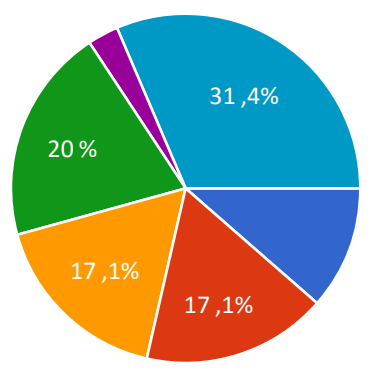

BLOCO 4 - Requisitos de Política de Gestão, Segurança e Transparência da Informação 28 A mudança de sistemática de gestão documental a partir de 2011 (NUP, GDC, Protocolo) facilitou a recuperação dos documentos.

$\begin{array}{rrr}\text { Discordo completamente } & 0 & 0 \% \\ \text { Discordo parcialmente } & 4 & 11.4 \% \\ \text { Nem discordo, nem concordo } & 6 & 17.1 \% \\ \text { Concordo parcialmente } & 12 & 34.3 \% \\ \text { Concordo completamente } & 9 & 25.7 \% \\ \text { Desconheço } & 4 & 11.4 \%\end{array}$

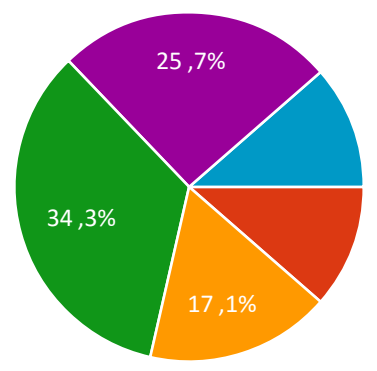

29 O NDA (Núcleo de Documentação e Arquivo) é um aliado importante na localização dos documentos e processos.

$\begin{array}{rrr}\text { Discordo completamente } & 0 & 0 \% \\ \text { Discordo parcialmente } & 1 & 2.9 \% \\ \text { Nem discordo, nem concordo } & 3 & 8.6 \% \\ \text { Concordo parcialmente } & 13 & 37.1 \% \\ \text { Concordo completamente } & 11 & 31.4 \% \\ \text { Desconheço } & 7 & 20 \%\end{array}$

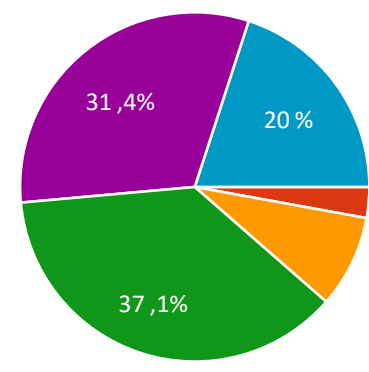


30. Tenho dificuldade em localizar documentos pelo NDA uma vez que a digitalização como imagem não me permite uma busca individualizada de documentos.

$\begin{array}{rrr}\text { Discordo completamente } & 1 & 2.9 \% \\ \text { Discordo parcialmente } & 2 & 5.7 \% \\ \text { Nem discordo, nem concordo } & 8 & 22.9 \% \\ \text { Concordo parcialmente } & 13 & 37.1 \% \\ \text { Concordo completamente } & 1 & 2.9 \% \\ \text { Desconheço } & 10 & 28.6 \%\end{array}$

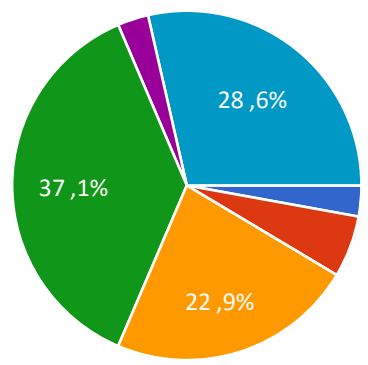

31 O GDC (Gestão de Documentos Correntes) é um sistema que contribui na localização dos processos na empresa.

$\begin{array}{rrr}\text { Discordo completamente } & 0 & 0 \% \\ \text { Discordo parcialmente } & 0 & 0 \% \\ \text { Nem discordo, nem concordo } & 3 & 8.6 \% \\ \text { Concordo parcialmente } & 17 & 48.6 \% \\ \text { Concordo completamente } & 14 & 40 \% \\ \text { Desconheço } & 1 & 2.9 \%\end{array}$

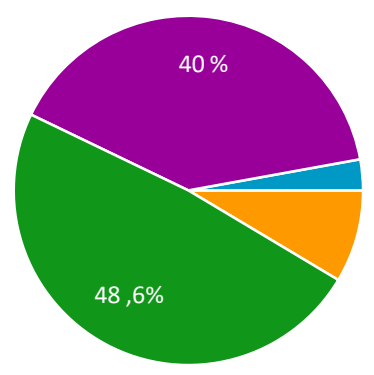

32 Há dificuldades em localizar documentos com origem anterior à 10(dez) anos atrás.

$\begin{array}{rrr}\text { Discordo completamente } & 0 & 0 \% \\ \text { Discordo parcialmente } & 1 & 2.9 \% \\ \text { Nem discordo, nem concordo } & 4 & 11.4 \% \\ \text { Concordo parcialmente } & 17 & 48.6 \% \\ \text { Concordo completamente } & 10 & 28.6 \% \\ \text { Desconheço } & 3 & 8.6 \%\end{array}$

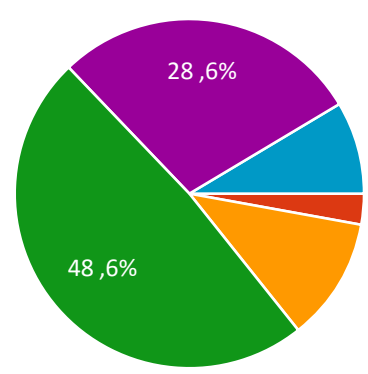


$33 \mathrm{Na}$ abertura de NUPs, e/ou criação de qualquer documento o assunto é informado corretamente o que possibilita localizar processos de assuntos relacionados.

$\begin{array}{rrr}\text { Discordo completamente } & 1 & 2.9 \% \\ \text { Discordo parcialmente } & 10 & 28.6 \% \\ \text { Nem discordo, nem concordo } & 3 & 8.6 \% \\ \text { Concordo parcialmente } & 19 & 54.3 \% \\ \text { Concordo completamente } & 2 & 5.7 \% \\ \text { Desconheço } & 0 & 0 \%\end{array}$

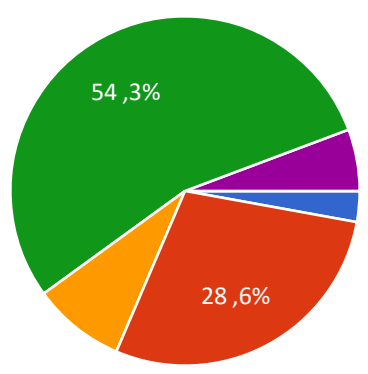

$34 \mathrm{Na}$ abertura de NUPs, e/ou criação de qualquer documento no GDC, o código de classificação do assunto dos documentos e processos está identificado o que contribui para o correto arquivamento e seu tempo de guarda.

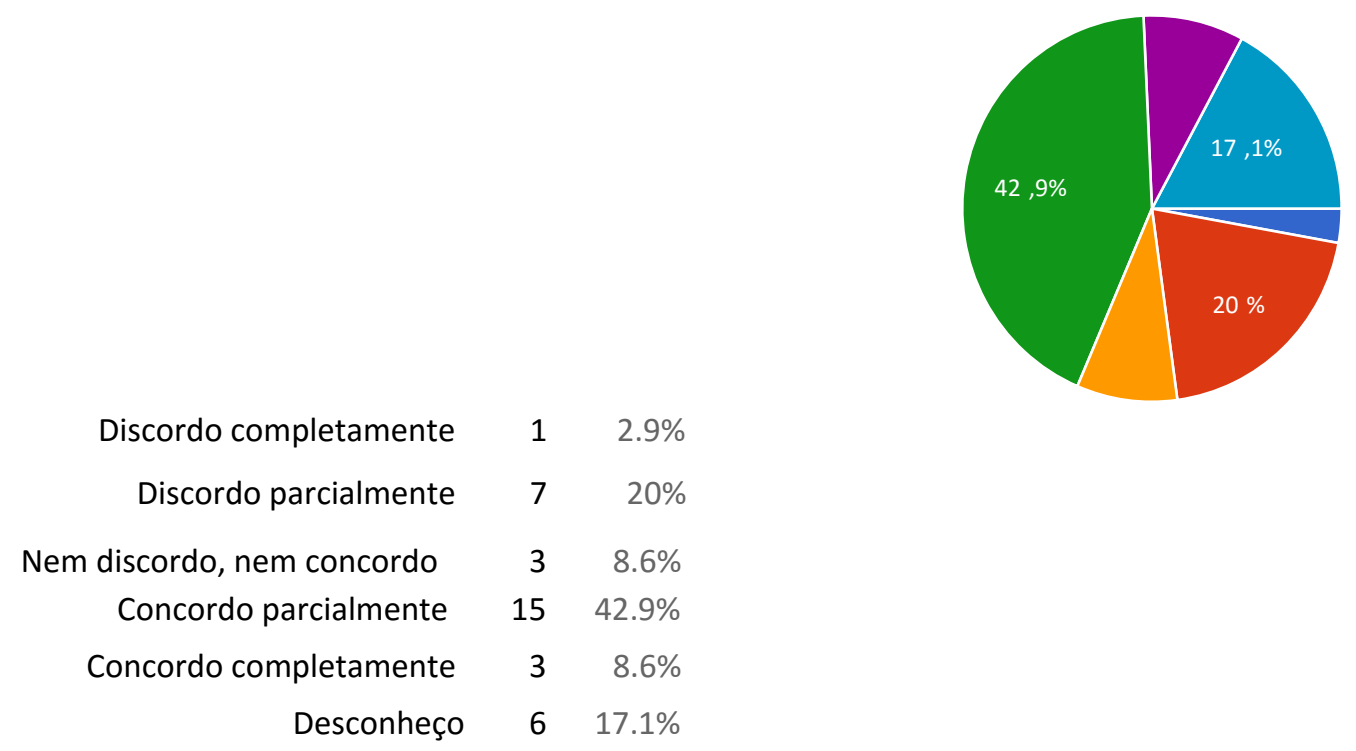

35 Conheço a atual política de preservação e eliminação de documentos da empresa.

$\begin{array}{rrr}\text { Discordo completamente } & 2 & 5.7 \% \\ \text { Discordo parcialmente } & 4 & 11.4 \% \\ \text { Nem discordo, nem concordo } & 2 & 5.7 \% \\ \text { Concordo parcialmente } & 18 & 51.4 \% \\ \text { Concordo completamente } & 7 & 20 \% \\ \text { Desconheço } & 2 & 5.7 \%\end{array}$

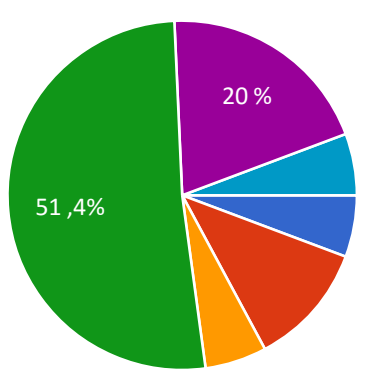


36 A área, como decorrência da Lei de Acesso à Informação, implementou política de gestão de informação.

$\begin{array}{rrr}\text { Discordo completamente } & 5 & 14.3 \% \\ \text { Discordo parcialmente } & 8 & 22.9 \% \\ \text { Nem discordo, nem concordo } & 6 & 17.1 \% \\ \text { Concordo parcialmente } & 11 & 31.4 \% \\ \text { Concordo completamente } & 4 & 11.4 \% \\ \text { Desconheço } & 1 & 2.9 \%\end{array}$

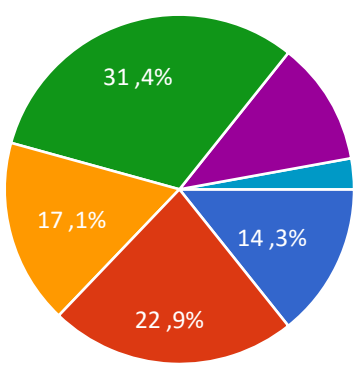

37 A área determinou procedimentos documentados de Proteção e Controle de Informações Sigilosas/Acesso Restrito.
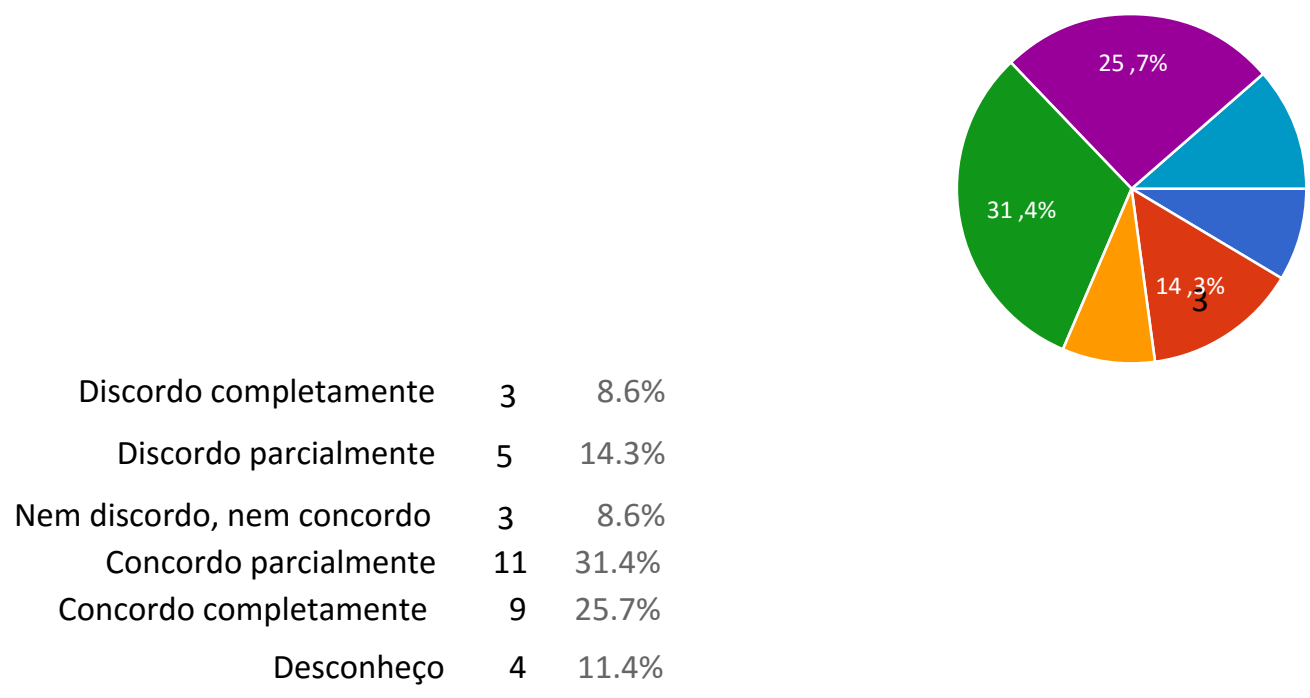

38 Houve modificação no entendimento da área acerca de informações que antes eram consideradas sigilosas e, a partir da LAI, passaram a ser públicas.

$\begin{array}{rrr}\text { Discordo completamente } & 1 & 2.9 \% \\ \text { Discordo parcialmente } & 3 & 8.6 \% \\ \text { Nem discordo, nem concordo } & 5 & 14.3 \% \\ \text { Concordo parcialmente } & 10 & 28.6 \% \\ \text { Concordo completamente } & 13 & 37.1 \% \\ \text { Desconheço } & 3 & 8.6 \%\end{array}$

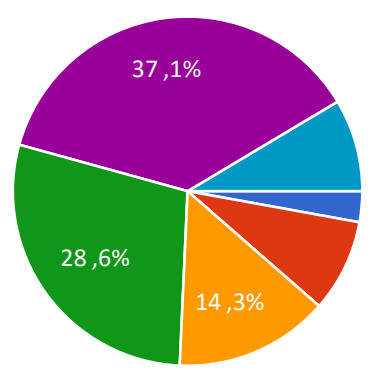


39 Houve atualização nos manuais da área (normas e procedimentos) em função da LAI

$\begin{array}{rrr}\text { Discordo completamente } & 5 & 14.3 \% \\ \text { Discordo parcialmente } & 2 & 5.7 \% \\ \text { Nem discordo, nem concordo } & 5 & 14.3 \% \\ \text { Concordo parcialmente } & 11 & 31.4 \% \\ \text { Concordo completamente } & 5 & 14.3 \% \\ \text { Desconheço } & 7 & 20 \%\end{array}$

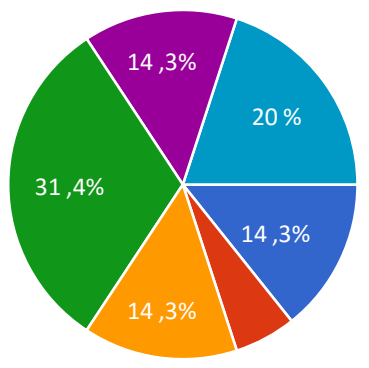

$40 \mathrm{~A}$ área definiu procedimentos internos para o tratamento e transporte de documentos classificados como de Acesso Restrito e/ou Sigilosos que em suporte digital deverá ser transmitida por meio da Internet ou da Rede Corporativa dos Correios, utilizando Virtual Private Network (VPN), criptografia ou certificação digital (MANTIC 5/8 - Anexo 2 - 5.9).

$\begin{array}{rrr}\text { Discordo completamente } & 2 & 5.7 \% \\ \text { Discordo parcialmente } & 5 & 14.3 \% \\ \text { Nem discordo, nem concordo } & 4 & 11.4 \% \\ \text { Concordo parcialmente } & 6 & 17.1 \% \\ \text { Concordo completamente } & 3 & 8.6 \% \\ \text { Desconheço } & 15 & 42.9 \%\end{array}$

41. A área tem política de Gestão do Conhecimento
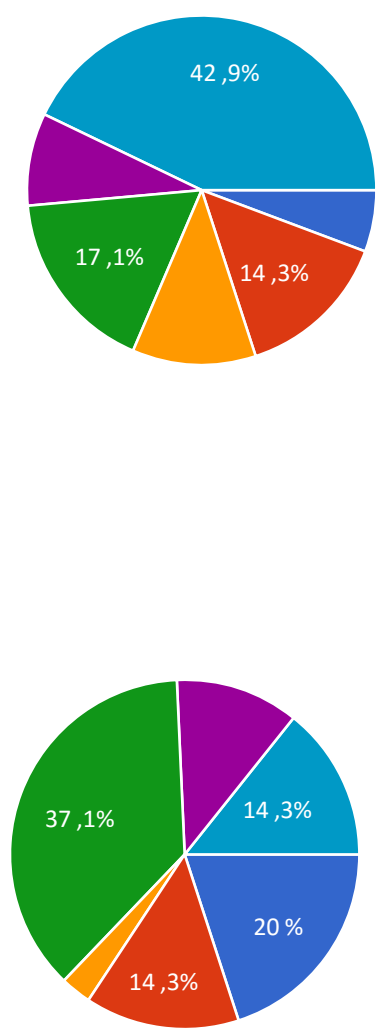
$42 \mathrm{~A}$ área criou uma rotina para identificação de informações de amplo interesse público para a publicação em transparência ativa

\begin{tabular}{rrr} 
Discordo completamente & \multicolumn{1}{c}{5} & $14.3 \%$ \\
Discordo parcialmente & 5 & $14.3 \%$ \\
Nem discordo, nem concordo & 3 & $8.6 \%$ \\
Concordo parcialmente & 12 & $34.3 \%$ \\
Concordo completamente & 2 & $5.7 \%$ \\
Desconheço & 8 & $22.9 \%$
\end{tabular}

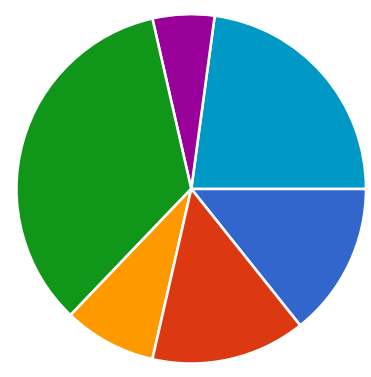

43.A área tomou por base os pedidos mais recorrentes/frequentes para incrementar a Seção de Acesso à Informação no sítio dos Correios

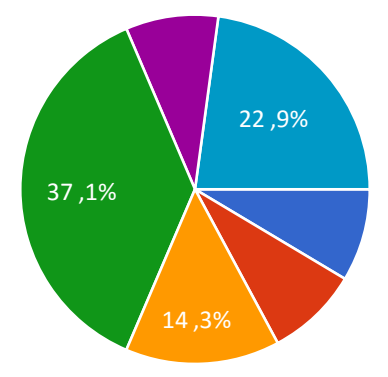

$\begin{array}{rrr}\text { Discordo completamente } & 3 & 8.6 \% \\ \text { Discordo parcialmente } & 3 & 8.6 \% \\ \text { Nem discordo, nem concordo } & 5 & 14.3 \% \\ \text { Concordo parcialmente } & 13 & 37.1 \% \\ \text { Concordo completamente } & 3 & 8.6 \% \\ \text { Desconheço } & 8 & 22.9 \%\end{array}$

44 A área possui rotina de atualização de suas informações na Seção de Acesso à Informação no sítio dos Correios.

$\begin{array}{rrr}\text { Discordo completamente } & 1 & 2.9 \% \\ \text { Discordo parcialmente } & 7 & 20 \% \\ \text { Nem discordo, nem concordo } & 2 & 5.7 \% \\ \text { Concordo parcialmente } & 15 & 42.9 \% \\ \text { Concordo completamente } & 4 & 11.4 \% \\ \text { Desconheço } & 6 & 17.1 \%\end{array}$

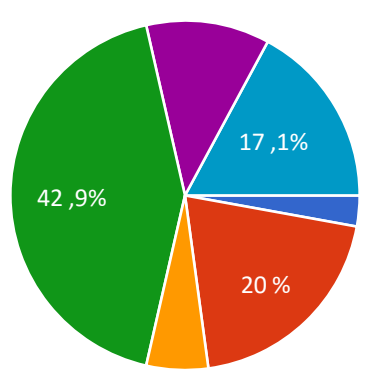


$45 \mathrm{~A}$ área promoveu a sensibilização dos servidores em exercício quanto aos seus deveres frente ao direito de acesso à informação do cidadão

$\begin{array}{rrr}\text { Discordo completamente } & 3 & 8.6 \% \\ \text { Discordo parcialmente } & 8 & 22.9 \% \\ \text { Nem discordo, nem concordo } & 1 & 2.9 \% \\ \text { Concordo parcialmente } & 14 & 40 \% \\ \text { Concordo completamente } & 7 & 20 \% \\ \text { Desconheço } & 2 & 5.7 \%\end{array}$

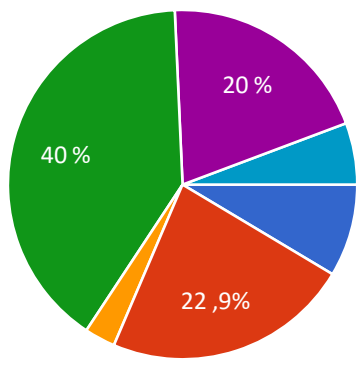

BLOCO 5 - Requisitos para disponibilização da informação

46. Os Correios é empresa pública e por isso deve ter transparência nas suas informações.

$\begin{array}{rrr}\text { Discordo completamente } & 0 & 0 \% \\ \text { Discordo parcialmente } & 2 & 5.7 \% \\ \text { Nem discordo, nem concordo } & 0 & 0 \% \\ \text { Concordo parcialmente } & 11 & 31.4 \% \\ \text { Concordo completamente } & 22 & 62.9 \% \\ \text { Desconheço } & 0 & 0 \%\end{array}$

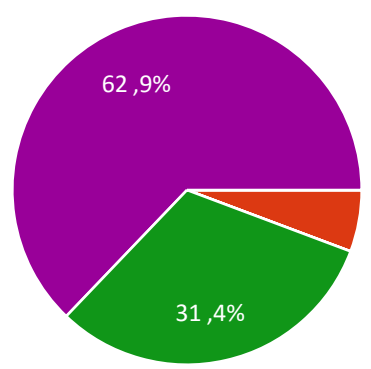

47 Os Correios, em que pese ser uma empresa pública, atua no âmbito concorrencial e essas informações devem ser restrita à alguns gestores.

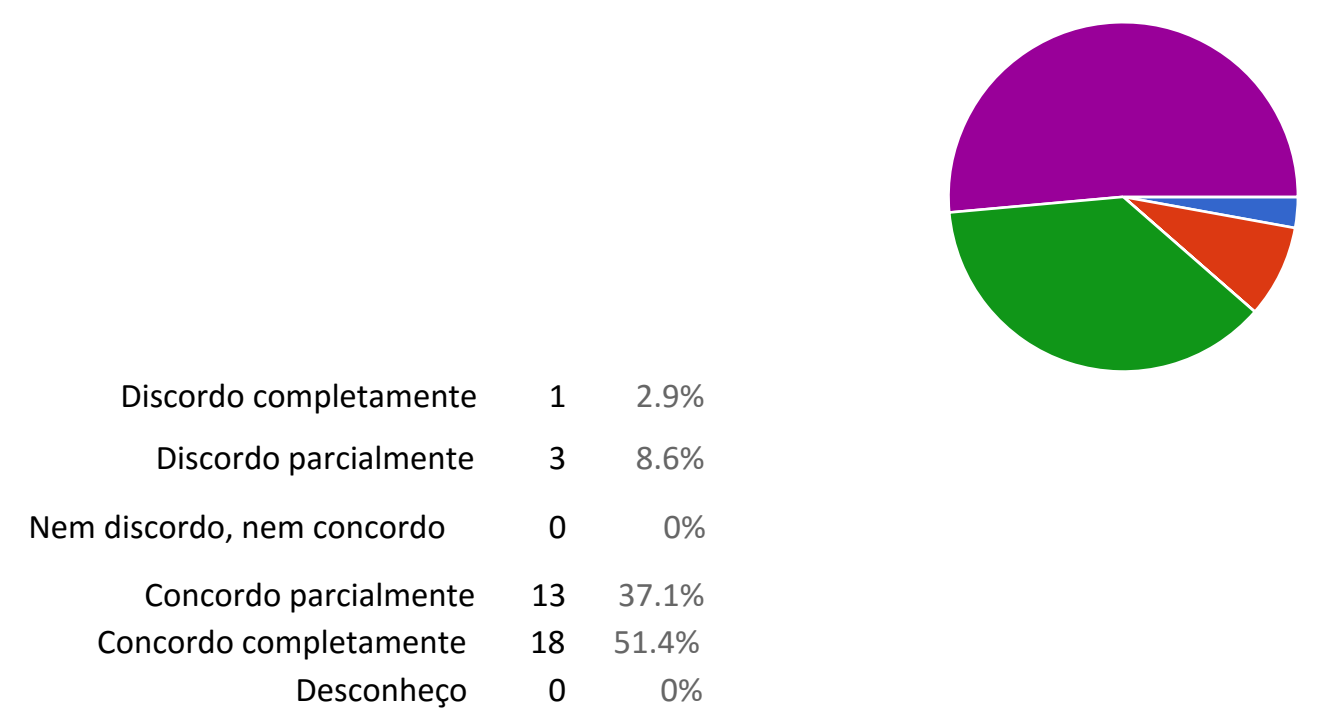


48 Uma empresa pública de direito privado, que atua no mercado competitivo, não pode ter suas informações públicas.

$\begin{array}{rrr}\text { Discordo completamente } & 4 & 11.4 \% \\ \text { Discordo parcialmente } & 15 & 42.9 \% \\ \text { Nem discordo, nem concordo } & 1 & 2.9 \% \\ \text { Concordo parcialmente } & 14 & 40 \% \\ \text { Concordo completamente } & 1 & 2.9 \% \\ \text { Desconheço } & 0 & 0 \%\end{array}$

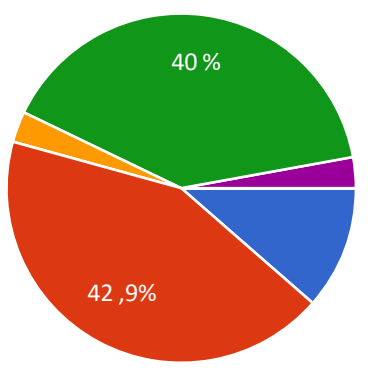

49 O monopólio postal previsto na Constituição Federal determina o compromisso público com a sociedade brasileira, e esta deve ter acesso a todas as informações da empresa.

$\begin{array}{rrr}\text { Discordo completamente } & 3 & 8.6 \% \\ \text { Discordo parcialmente } & 10 & 28.6 \% \\ \text { Nem discordo, nem concordo } & 1 & 2.9 \% \\ \text { Concordo parcialmente } & 16 & 45.7 \% \\ \text { Concordo completamente } & 5 & 14.3 \% \\ \text { Desconheço } & 0 & 0 \%\end{array}$

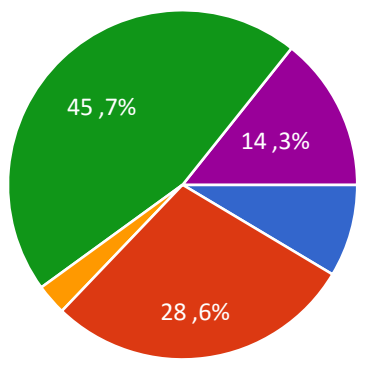

50 Os Correios deveriam ter autonomia e independência de qualquer órgão e decidir o que deve ou não ser disponibilizado

$\begin{array}{rrr}\text { Discordo completamente } & 4 & 11.4 \% \\ \text { Discordo parcialmente } & 9 & 25.7 \% \\ \text { Nem discordo, nem concordo } & 3 & 8.6 \% \\ \text { Concordo parcialmente } & 13 & 37.1 \% \\ \text { Concordo completamente } & 6 & 17.1 \% \\ \text { Desconheço } & 0 & 0 \%\end{array}$

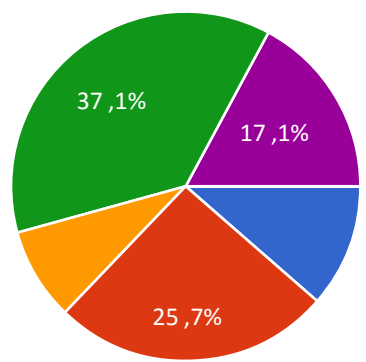


Apêndice D - Relatório da Pesquisa de Satisfação

A Pesquisa de Satisfação foi introduzida no sistema e-SIC em 16 de novembro de 2012 e sofreu uma alteração, com o a nova versão do sistema em dia 02 de outubro de 2014, às 21 horas, quando da liberação da versão 2.1.7 do e-SIC. A seguir apresentamos as tabelas de correlação e apuração dos dados que estão representados nas Tabelas 13 a 19.

1)Dados da ECT - A Pesquisa de Satisfação começou seis meses depois de entrada em vigor da LAI, assim estamos contabilizando os dados de pedidos de informações e respostas a pesquisa de satisfação de $1^{\circ}$ de dezembro de 2012 à 31 de dezembro de 2015 .

Total de pedidos de informação registrados de maio/2012 a dezembro/2015: 6.773

Total de pedidos de informação registrados de dezembro/2012 a dezembro/2015: 5.649 (universo com Pesquisa de Satisfação disponível)

Total de pedidos de informação em que os solicitantes responderam ao questionário: 841 (15\%)

Tabela - Sistematização dos resultados da Pesquisa de Satisfação

\begin{tabular}{|c|c|c|c|c|c|c|c|c|}
\hline \multicolumn{9}{|c|}{ PESQUISA DE SATISFAÇÃO - Periodo de maio/2012 a dez/2015 } \\
\hline $\begin{array}{l}\text { Pedido de Informação: Tipo de } \\
\text { Resposta dada pela ECT }\end{array}$ & $\begin{array}{c}\text { Total de Pedidos } \\
\text { de Informação } \\
\text { (mai/2012 a } \\
\text { dez/2015) }\end{array}$ & $\begin{array}{c}\text { Total de Pedidos } \\
\text { de Informação } \\
\text { (dez/2012 a } \\
\text { dez/2015) }\end{array}$ & $\begin{array}{c}\text { Respostas à } \\
\text { Pesquisa de } \\
\text { Satisfação }\end{array}$ & $\begin{array}{c}\%(\operatorname{dez} / 2012 \mathrm{a} \\
\operatorname{dez} / 2015)\end{array}$ & $\begin{array}{c}\text { PRAZO } \\
\text { PRORROGADO }\end{array}$ & $\%$ & $\begin{array}{c}\text { RESPOSTA } \\
\text { FORA DO } \\
\text { PRAZO }\end{array}$ & $\%$ \\
\hline Acesso Concedido & 5.479 & 4.495 & 741 & 16,5 & 224 & 30,2 & 59 & 8,0 \\
\hline Acesso Negado & 370 & 308 & 59 & 19,2 & 24 & 40,7 & 4 & 6,8 \\
\hline Acesso Parcialmente Concedido & 205 & 166 & 15 & 9,0 & 11 & 73,3 & 4 & 26,7 \\
\hline Informação Inexistente & 103 & 88 & 5 & 5,7 & 3 & 60,0 & 0 & 0,0 \\
\hline Não se trata de solicitação de informação & 427 & 427 & 8 & 1,9 & 0 & 0,0 & 0 & 0,0 \\
\hline $\begin{array}{l}\text { Órgão não tem competência para } \\
\text { responder sobre o assunto }\end{array}$ & 47 & 42 & 4 & 9,5 & 1 & 25,0 & 0 & 0,0 \\
\hline Pergunta Duplicada/Repetida & 142 & 123 & 9 & 7,3 & 5 & 55,6 & 0 & 0,0 \\
\hline Total de PI - pesquisa respondida & 6.773 & 5.649 & 841 & 14,9 & 268 & 31,9 & 67 & 8,0 \\
\hline
\end{tabular}

Obs: as perguntas do questionário são respondidas a cada pedido de informação respondido pelo órgão ao qual foi solicitado o pedido. Assim podem existir pedidos de informação com o mesmo solicitante, por isso a análise da Pesquisa de Satisfação deve ser referenciada ao número de pedidos de informação registradas e avaliadas pelo cidadão. 
Tabelas de correlação das perguntas e respostas

Tipo de Resposta: Acesso Concedido

\begin{tabular}{|c|c|c|c|c|c|}
\hline & $\begin{array}{c}\text { ACESSO } \\
\text { CONCEDIDO } \\
\end{array}$ & Pergunta 1 & Pergunta 2 & Pergunta 3 & Pergunta 4 \\
\hline \multirow{5}{*}{ 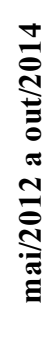 } & Texto & $\begin{array}{l}\text { A resposta é de fácil } \\
\text { compreensão }\end{array}$ & $\begin{array}{l}\text { A resposta atende às } \\
\text { minhas expectativas }\end{array}$ & $\begin{array}{l}\text { O órgão foi prestativo e } \\
\text { cordial na resposta }\end{array}$ & Comentários \\
\hline & \multirow{4}{*}{ Respostas } & *Discordo Totalmente & *Discordo Totalmente & *Discordo Totalmente & \multirow{4}{*}{ Redação livre } \\
\hline & & *Discordo & *Discordo & *Discordo & \\
\hline & & *Concordo & *Concordo & *Concordo & \\
\hline & & *Concordo Totalmente & *Concordo Totalmente & *Concordo Totalmente & \\
\hline \multirow{6}{*}{ 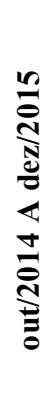 } & Texto & $\begin{array}{l}\text { A resposta fornecida foi } \\
\text { de fácil compreensão? }\end{array}$ & $\begin{array}{l}\text { A resposta fornecida } \\
\text { atendeu plenamente ao } \\
\text { seu pedido? }\end{array}$ & RETIRADA & Comentários \\
\hline & \multirow{5}{*}{ Respostas } & 1 - Não atendeu & 1 - Não atendeu & \multirow{5}{*}{ RETIRADA } & \\
\hline & & $2-$ & $2-$ & & \\
\hline & & $3-$ & $3-$ & & \\
\hline & & $4-$ & $4-$ & & \\
\hline & & 5-Atendeu Plenamente & 5 - Atendeu Plenamente & & \\
\hline
\end{tabular}

Tipo de Resposta: Demais Opções(*)

\begin{tabular}{|c|c|c|c|c|c|}
\hline & DEMAIS OPÇÕES & Pergunta 1 & Pergunta 2 & Pergunta 3 & Pergunta 4 \\
\hline \multirow{5}{*}{ 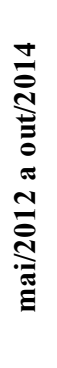 } & Texto & $\begin{array}{l}\text { A justificativa para a } \\
\text { negativa do acesso é de } \\
\text { fácil compreensão. }\end{array}$ & $\begin{array}{l}\text { A justificativa para a } \\
\text { negativa do acesso foi } \\
\text { satisfatória. }\end{array}$ & $\begin{array}{l}\text { O órgão foi prestativo e } \\
\text { cordial na resposta }\end{array}$ & Comentários \\
\hline & \multirow{4}{*}{ Respostas } & *Discordo Totalmente & *Discordo Totalmente & *Discordo Totalmente & \multirow{4}{*}{ Redação livre } \\
\hline & & *Discordo & *Discordo & *Discordo & \\
\hline & & *Concordo & *Concordo & *Concordo & \\
\hline & & *Concordo Totalmente & *Concordo Totalmente & *Concordo Totalmente & \\
\hline \multirow{6}{*}{ 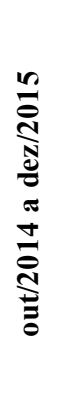 } & Texto & $\begin{array}{l}\text { A justificativa fornecida } \\
\text { foi de fácil } \\
\text { compreensão? }\end{array}$ & $\begin{array}{l}\text { A justificativa para o não } \\
\text { fornecimento da informação } \\
\text { foi satisfatória? }\end{array}$ & RETIRADA & Comentários \\
\hline & \multirow{5}{*}{ Respostas } & 1 - Difícil compreensão & 1 - Não atendeu & \multirow{5}{*}{ RETIRADA } & \multirow{5}{*}{ Redação livre } \\
\hline & & $2-$ & $2-$ & & \\
\hline & & $3-$ & $3-$ & & \\
\hline & & $4-$ & $4-$ & & \\
\hline & & 5- Fácil compreensão & 5 - Atendeu Plenamente & & \\
\hline
\end{tabular}

(*)Acesso Negado; Acesso Parcialmente Concedido, Informação Inexistente; Não se trata de solicitação de informação; Órgão não tem competência para responder sobre o assunto e Pergunta Duplicada/Repetida

3) Equivalência

Concordo totalmente $=5$ Atendeu 
Concordo $=4$

Discordo $=2$

Discordo totalmente $=1$ Não atendeu

\begin{tabular}{|l|l|c|}
\hline \multicolumn{1}{|c|}{ mai/2012 a out/2014 } & \multicolumn{1}{c|}{ out/2014 A dez/2015 } & padrão \\
\hline *Discordo Totalmente & $1-$ Não atendeu & $\mathbf{1}$ \\
\hline *Discordo & 2 - & $\mathbf{2}$ \\
\hline sem equivalência & $3-$ & $\mathbf{3}$ \\
\hline *Concordo & $4-$ & $\mathbf{4}$ \\
\hline *Concordo Totalmente & 5 - Atendeu Plenamente & $\mathbf{5}$ \\
\hline
\end{tabular}

4) Apuração das respostas e construção das tabelas

Perguntas Tipo de Resposta da ECT: ACESSO CONCEDIDO

\begin{tabular}{|c|c|c|c|c|c|c|c|c|}
\hline & Pergunta 1 & mai/2012 a out/2014 & & out/2014 A dez/2015 & & & Total & \\
\hline \multirow{6}{*}{ 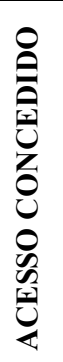 } & Texto & $\begin{array}{l}\text { A resposta é de fácil } \\
\text { compreensão }\end{array}$ & 372 & $\begin{array}{l}\text { A resposta fornecida } \\
\text { foi de fácil } \\
\text { compreensão? }\end{array}$ & 369 & 741 & $\%$ & $\%$ \\
\hline & \multirow{5}{*}{ Respostas } & *Discordo Totalmente & 65 & 1 - Não atendeu & 79 & 144 & 19,43 & \multirow{2}{*}{28,07} \\
\hline & & *Discordo & 33 & $2-$ & 31 & 64 & 8,64 & \\
\hline & & & & $3-$ & 32 & 32 & 4,32 & \\
\hline & & *Concordo & 136 & $4-$ & 42 & 178 & 24,02 & \multirow{2}{*}{67,61} \\
\hline & & *Concordo Totalmente & 138 & 5 - Atendeu Plenamente & 185 & 323 & 43,59 & \\
\hline
\end{tabular}

\begin{tabular}{|c|c|c|c|c|c|c|c|c|}
\hline & Pergunta 2 & mai/2012 a out/2014 & & out/2014 A dez/2015 & & & Total & \\
\hline \multirow{6}{*}{ 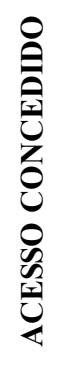 } & Texto & $\begin{array}{l}\text { A resposta atende às } \\
\text { minhas expectativas }\end{array}$ & 372 & $\begin{array}{l}\text { A resposta fornecida } \\
\text { atendeu plenamente } \\
\text { ao seu pedido? }\end{array}$ & 369 & 741 & $\%$ & $\%$ \\
\hline & \multirow{5}{*}{ Respostas } & *Discordo Totalmente & 154 & 1 - Não atendeu & 202 & 356 & 48,04 & \multirow{2}{*}{58,43} \\
\hline & & *Discordo & 55 & $2-$ & 22 & 77 & 10,39 & \\
\hline & & & & $3-$ & 20 & 20 & 2,70 & \\
\hline & & *Concordo & 74 & $4-$ & 20 & 94 & 12,69 & \multirow{2}{*}{38,87} \\
\hline & & *Concordo Totalmente & 89 & 5 - Atendeu Plenamente & 105 & 194 & 26,18 & \\
\hline
\end{tabular}

\begin{tabular}{|c|c|c|c|c|c|c|c|c|}
\hline & Pergunta 3 & mai/2012 a out/2014 & & out/2014 A dez/2015 & & \multicolumn{3}{|c|}{ Total } \\
\hline \multirow{6}{*}{ 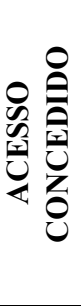 } & Texto & $\begin{array}{l}\text { O órgão foi prestativo } \\
\text { e cordial na resposta }\end{array}$ & 372 & RETIRADA & $\mathbf{0}$ & 372 & $\%$ & $\%$ \\
\hline & \multirow{5}{*}{ Respostas } & *Discordo Totalmente & 69 & & & 69 & 18,55 & \multirow{2}{*}{29,30} \\
\hline & & *Discordo & 40 & & & 40 & 10,75 & \\
\hline & & & & & & $\mathbf{0}$ & 0,00 & \\
\hline & & *Concordo & 142 & & & 142 & 38,17 & \multirow{2}{*}{70,70} \\
\hline & & *Concordo Totalmente & 121 & & & 121 & 32,53 & \\
\hline
\end{tabular}




\begin{tabular}{|c|c|c|c|c|c|c|c|}
\hline & Pergunta 4 & mai/2012 a out/2014 & & out $/ 2014 \mathrm{~A}$ dez/2015 & & \multicolumn{2}{|c|}{ Total } \\
\hline \multirow{3}{*}{ 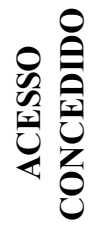 } & Texto & Comentários & 372 & Comentários & 369 & 741 & $\%$ \\
\hline & \multirow{2}{*}{ Respostas } & com comentários & 181 & com comentários & 196 & 377 & 50,88 \\
\hline & & sem comentários & 191 & sem comentários & 173 & 364 & 49,12 \\
\hline
\end{tabular}

Perguntas Tipo de Resposta da ECT: DEMAIS OPÇÕES

\begin{tabular}{|c|c|c|c|c|c|c|c|c|}
\hline & Pergunta 1 & mai/2012 a out/2014 & & out/2014 A dez/2015 & & \multicolumn{3}{|c|}{ Total } \\
\hline \multirow{6}{*}{ 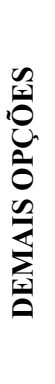 } & Texto & $\begin{array}{l}\text { A jus tificativa para a } \\
\text { negativa do acesso é de } \\
\text { fácil compreensão. }\end{array}$ & 33 & $\begin{array}{l}\text { A justificativa fornecida foi } \\
\text { de fácil compreensão? }\end{array}$ & 67 & 100 & $\%$ & $\%$ \\
\hline & \multirow{5}{*}{ Respostas } & *Discordo Totalmente & 13 & 1 - Difícil compreensão & 32 & 45 & 45,0 & \multirow{2}{*}{55,00} \\
\hline & & *Discordo & 5 & $2-$ & 5 & 10 & 10,0 & \\
\hline & & & & $3-$ & 6 & 6 & 6,0 & \\
\hline & & *Concordo & 9 & $4-$ & 6 & 15 & 15,0 & \multirow{2}{*}{39,00} \\
\hline & & *Concordo Totalmente & 6 & 5 - Fácil compreensão & 18 & 24 & 24,0 & \\
\hline
\end{tabular}

\begin{tabular}{|c|c|c|c|c|c|c|c|c|}
\hline & Pergunta 2 & mai/2012 a out $/ 2014$ & & out/2014 A dez/2015 & & \multicolumn{3}{|c|}{ Total } \\
\hline \multirow{6}{*}{ 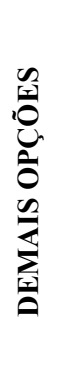 } & Texto & $\begin{array}{l}\text { A jus tificativa para a } \\
\text { negativa do acesso foi } \\
\text { satis fatória. }\end{array}$ & 33 & $\begin{array}{l}\text { A jus tificativa para o não } \\
\text { fornecimento da informação } \\
\text { foi s atis fatória? }\end{array}$ & 67 & 100 & $\%$ & $\%$ \\
\hline & \multirow{5}{*}{ Respostas } & *Discordo Totalmente & 19 & 1 - Não atendeu & 46 & 65 & 65,00 & \multirow{2}{*}{76,00} \\
\hline & & *Discordo & 8 & $2-$ & 3 & 11 & 11,00 & \\
\hline & & & & $3-$ & 8 & 8 & 8,00 & \\
\hline & & *Concordo & 3 & $4-$ & 2 & 5 & 5,00 & \multirow{2}{*}{16,00} \\
\hline & & *Concordo Totalmente & 3 & 5 - Atendeu Plenamente & 8 & 11 & 11,00 & \\
\hline
\end{tabular}

\begin{tabular}{|c|c|c|c|c|c|c|c|c|}
\hline & Pergunta 3 & mai/2012 a out/2014 & & out $/ 2014$ A dez/2015 & & Total & & \\
\hline \multirow{6}{*}{ 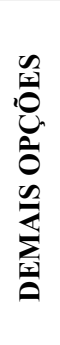 } & Texto & $\begin{array}{l}\text { O órgão foi prestativo e } \\
\text { cordial na resposta }\end{array}$ & 33 & RETIRADA & $\mathbf{0}$ & 33 & $\%$ & $\%$ \\
\hline & \multirow{5}{*}{ Respostas } & *Discordo Totalmente & 9 & & & 9 & 27,27 & \multirow{2}{*}{45,45} \\
\hline & & \multirow[t]{2}{*}{ *Discordo } & 6 & & & 6 & 18,18 & \\
\hline & & & & & & $\mathbf{0}$ & 0,00 & \\
\hline & & *Concordo & 10 & & & 10 & 30,30 & \multirow{2}{*}{54,55} \\
\hline & & *Concordo Totalmente & 8 & & & 8 & 24,24 & \\
\hline
\end{tabular}

\begin{tabular}{|c|c|c|c|c|c|c|c|}
\hline & Pergunta 4 & mai/2012 a out/2014 & & out $/ 2014$ A dez/2015 & & Total & \\
\hline \multirow{3}{*}{ 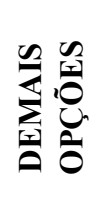 } & Texto & Comentários & 33 & Comentários & 67 & 100 & $\%$ \\
\hline & \multirow{2}{*}{ Respostas } & com comentários & 19 & com comentários & 37 & 56 & 56,0 \\
\hline & & sem comentários & 14 & sem comentários & 30 & 44 & 44,0 \\
\hline
\end{tabular}


ANEXO

Anexo I - Termo de Ajustamento de Conduta (TAC) 
PROCURADO:IA DA REPÚBLICA NO DISTRITO FEDERAL

TERMO DE AJUSTAMENTO DE CONDUTA

Inquérito Civil $n^{\circ} 1.16 .000 .000919 / 2005-09$

MINISTÉRIO PÚBLICO FEDERAL, doravante denominado MPF, por intermédio dos Procuradores da República abaixo assinados, lotados na Procuradoria da República no Distrito Federal, no exercício de suas atribuições legais, notadamente aquelas insculpidas no artigo $5^{\circ}, \S 6^{\circ}$, da Lei $n^{\circ} 7.347 / 85$, RESOLVE tomar o presente compromisso de ajustamento de conduta da EMPRESA BRASILEIRA DE CORREIOS E TELÉGRAFOS, doravante denominada ECT, nesse ato representada por seu Presidente e por seus Diretores, acompanhados do Sr. Chefe de Gabinete da Presidência da ECT e pelo Sr. Chefe do Departamento Jurídico, nos seguintes termos:

Considerando que a Administração Pública rege-se pelos princípios da legalidade, impessoalidade, moralidade, publicidade e eficiência e, também, pelo princípia da segurança jurídica, a teor do artigo 37, caput, da Constituição Federal;

Considerando que o artigo 38 da Lei Federal $n^{\circ} 8.666 / 93$, que institui normas para licitações e contratos no âmbito da Administração Pública Federal, direta e indireta, estatui que tod s. os procedimentos licitatórios serão iniciados com a abertura de processo administ útivo, devidamente autuado, protocolado e numerado, contendo rol exemplificativs de documentos obrigatórios concernentes à licitação, consoante parágrafo único do sobredito artigo;

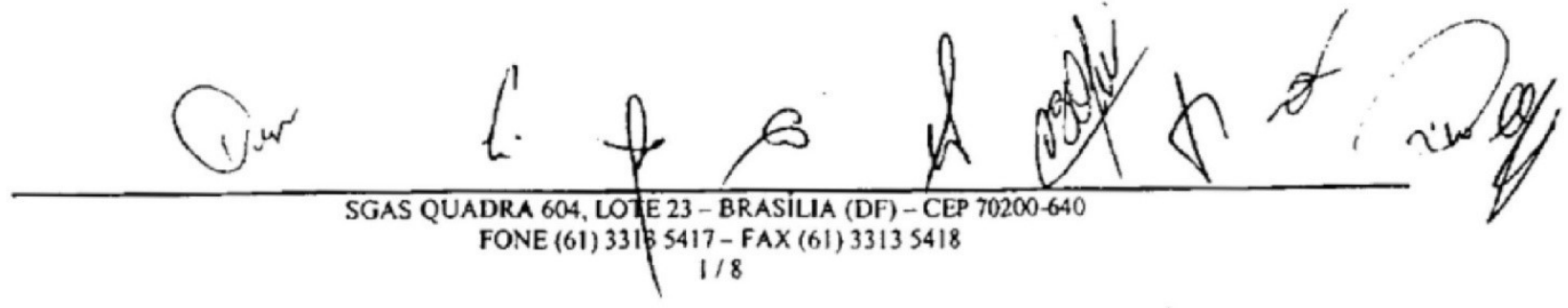


MINISTÉRIO PÚBLICO FEDERAL

\section{PROCURADORIA DA REPÚBLICA NO DISTRITO FEDERAL}

Considerando que os contratos e seus aditamentos serão lavrados nas repartições interessadas, as quais manterão arquivo cronológico dos seus autógrafos e registro sistemático do seu extrato, a teor do artigo 60 da Lei Federal n 8.666/93;

Considerando que a execução do contrato deverá ser acompanhada e fiscalizada por representante da Administração Pública especialmente designado, permitida a contratação de terceiros para assisti-lo e subsidiá-lo de informações pertinentes a essa atribuição, por força do artigo 67 da Lei Federal n 8.666/93;

Considerando que a Lei Federal $n^{\circ} 9.784 / 99$, que regula o processo administrativo no âmbito da Administração Pública Federal, em seu artigo 22, $\S 4^{\circ}$, preceitua que o processo administrativo deverá ter suas páginas numeradas sequencialmente e rubricadas;

Considerando o contido no relatório de informação n ${ }^{0-4} 409 / 2006$, lavrado pela então Divisão de Pesquisa, Análise e Informação (DSPAI) da Procuradoria da República no Distrito Federal (Apenso XXI do inquérito civil público 1.16.000.000919/2005-09), em atendimento às requisições exaradas pelo Ministério Público Federal, por meio dos oficios 190 e 195/2006/PR/DF/BCA, tendo por objeto a requisição dos originais de todos os processos de contratação da ECT envolvendo 24 (vinte e quatro) empresas listadas no relatório de análise $\mathrm{n}^{\circ} 1.227 / 2006$, cujo conteúdo é de conhecimento da ECT;

Considerando que os servidores do MPF que cumpriram a diligência, por meio do relatório de informação supra, detectaram "grande quantidade de documentos sem autuação(...), ocorrências de páginas fora de ordem, ausência de cronologia, páginas sem autuação, numeração com rasura, numeração ilegivel, páginas com mais de um número, além de outras ocorrências", as quais estão detalhadas nas tabelas anexas ao oficio 0591/PR, de 19 de setembro de 2006;

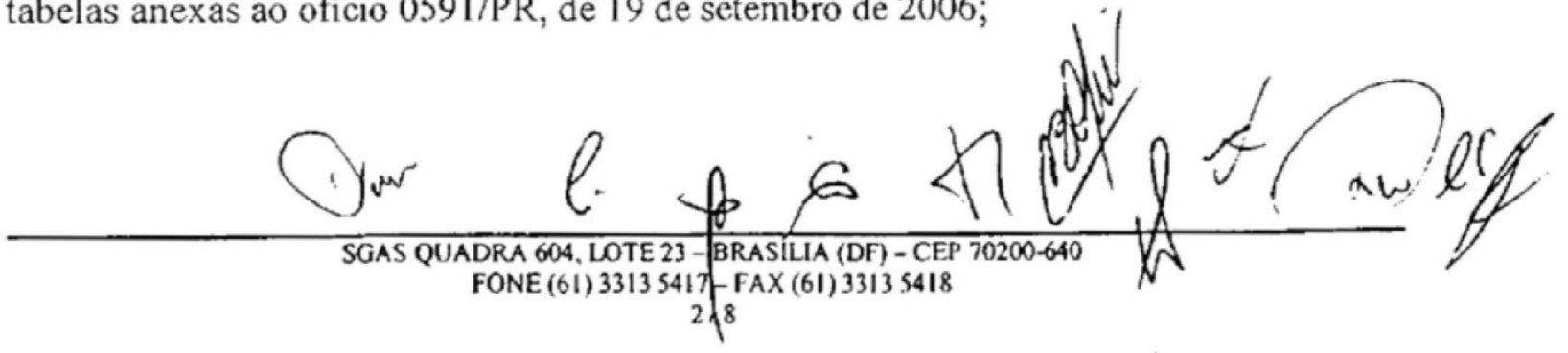




\section{MINISTÉRIO PÚBLICO FEDERAL \\ PROCUR.ADORIA DA REPÚBLICA NO DISTRITO FEDERAL}

Considerando que, nesse mesmo relatório de informação, verificou-se o expurgo do contrato $\mathrm{n}^{\circ} 8.904 / 1997 \mathrm{com}$ a empresa MARFINITE PRODUTOS SINTÉTICOS LTDA., malferindo assim o artigo 60 da Lei Federal n $n^{\circ}$ 8.666/93 e acarretando prejuizos irreparáveis à investigação em curso no Ministério Público Federal e no Departamento de Policia Federal, visto que sobredita pessoa juridica, inclusive, figura nos arquivos objeto do Relatório de Análise n 1.227/2006-DSPAI;

Considerando que tais investigações versam acerca de Correio Hibrido Postal, Banco Postal, Rede Postal Noturna, Aquisição de Veículos, Agências Franqueadas, Marketing e Publicidade, Obras, além de dezenas de contratações geridas pela Diretoria da Área de Administração, no período de 2002 até 2006;

Considerando que a ECT dispôs-se a subscrever Termo de Ajustamento de Conduta, visando adequar-se às normas que disciplinam a organização e guarda dos documentos concernentes às licitações e contrataçôes, consoante ata de reunião de 10 de agosto de 2007, referente ao Inquérito Civil $n^{\circ} 1.16 .000 .000085 / 2005$ 23, de conhecimento da ECI;

Considerando que a Lei Federal 7.347/85, em seu artigo $5^{\circ}, \S 6^{\circ}$, possibilita que os órgãos públicos legitimados tomem dos interessados compromisso de ajustamento de sua conduta às exigências legais, mediante cominações, com eficácia de título executivo extrajudicial;

RESOLVEM o seguinte:

CLÁUSULA PRIMEIRA: Nas contratações centralizadas ou não, independentemente de quais sejam as unidades gestoras, a ECT compromete-se a observar a regra do artigo 67 da Lei Federal 8.666/93, de sorte a designar, especialmente, dentro de 30 (trinta) dias

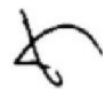


úteis contados desta data, empregados da ECT como representantes da Administração, para fins de acompanhamento e fiscalização de cada uma das contratações em curso na data da assinatura deste Termo de Ajustamento de Conduta;

CLÁUSULA SEGUNDA: Nos processos licitatórios e nos de gestão dos contratos respectivos, presente ou futuros, independentemente de quais sejam as unidades gestoras envolvidas, a ECT compromete-se a:

ALÍNEA "A": iniciar e instruir o processo licitatório na forma estipulada pelo artigo 38 e seu parágrafo único da Lei Federal 8.666/93;

ALÍNEA "B": manter arquivo cronológico dos autógrafos e registro sistemático do extrato dos contratos e documentos equivalentes, de acordo com o artigo 60 da Lei Federal n $8.666 / 93$;

ALÍNEA "C": numerar sequencialmente e rubricar todas as páginas dos processos administrativos de licitação e contratação, a teor do artigo 22, $\S 4^{\circ}$, da Lei Federal 9.784/99;

CLÁUSULA TERCEIRA: Em todas as contratações centralizadas ou não, de valor global superior a R\$1.500.000,00 (um milhão e quinhentos mil reais), cujos contratos jáse encontrem formalmente encerrados na data da assinatura deste Termo de Ajustamento, a ECT providenciará a guarda em local com acesso controlado, pelo prazo de 10 (dez) anos, contados da assinatura deste Termo;

PARÁGRAFO ÚNICO: Os processos serão guard’dos em seu atual estágio de organização mantendo-se a sua integridade.

CLÁUSULA QUARTA: A ECT compromete-se a manter arquivado, por 10 (dez) anos, contados a partir da apresentação dos Relatórios de Gestão ao TCU, rẹferentes ao

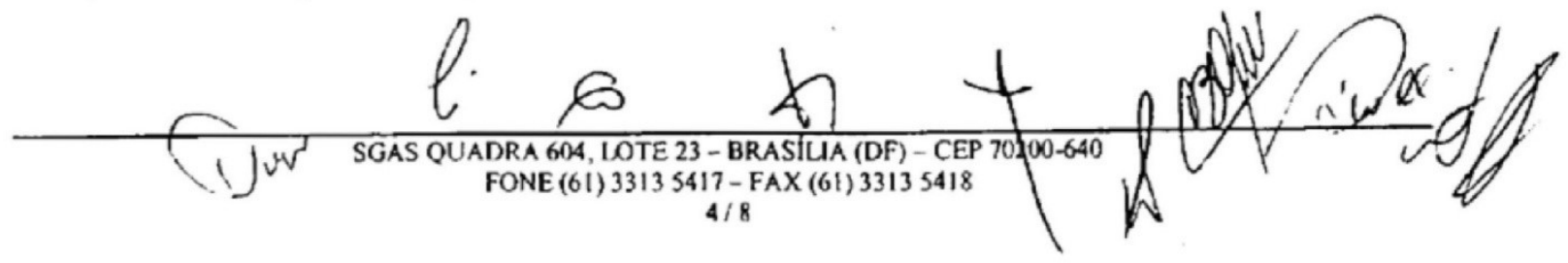




\section{MINISTÉRIO PÚBLICO FEDERAL \\ PrOCURADORIA DA REPÚBLICA NO DISTRITO FEDERAL}

ano de encerramento do contrato, todos os processos administrativos atinentes à licitação e à gestão de contratos:

PARÁGRAFO ÚNICO: A ECT compromete-se a não expurgar quaisquer documentos relacionados aos processos de contratação sob investigação do Ministério Público Federal, da Controladoria Geral da União, do Tribunal de Contas da União e da Polícia Federal ou que estejam sub judice, sempre que nesse sentido receber recomendação ou solicitação dos órgãos interessados ou então tiver ciência, formal, da existência de investigações, ações judiciais e/ou procedimentos de controle:

CLAÚSULA QUINTA: Em caso de descumprimento da cláusula primeira, a multa será de $R \$ 25.000 .00$ (vinte e cinco mil reais) para cada processo administrativo onde seja verificada a inexistência de designação formal e especial de representante da Administração para fins de acompanhamento e fiscalização da contratação respectiva;

CLÁUSULA SEXTA: Na hipótese de descumprimento das cláusulas segunda e terceira, a multa será de RS 5.000,00 (cinco mil reais), toda vez que forem verificadas desconformidades com o artigo 38 e seu parágrafo único da Lei Federal, c/c artigo 60, ambos da Lei Federal n ${ }^{\circ} .8 .666 / 93$, e artigo 22, $\S 4^{\circ}$, da Lei Federal 9.784/99;

CLÁUSULA SÉTIMA: Na hipótese de descumprimento da cláusula quarta e do seu parágrafo único, a multa será de $\mathrm{R} \$ 50.000 .00$ (cinquenta mil reais):

CLÁUSULA OITAVA: Em caso de descumprimento das cláusulas primeira, segunda, terceira ou quarta, a ECT deverá, por determinação de seu Presidente, na Administração Central, e do Diretor Regional, em âmbito Regional, instaurar Sindicância ou Processo Administrativo Disciplinar, assegurado o contraditório e a ampla defesa, visando apirar a responsabilidade do empregado ou detentor de cargo em comissão que lhe tenha dado causa:

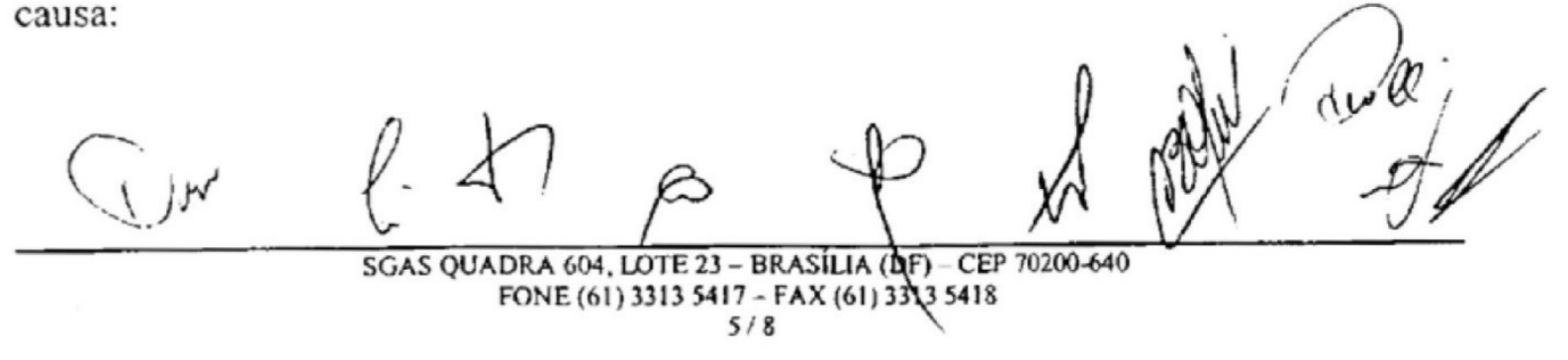


PARÁGRAFO PRIMEIRO: Caso o processo administrativo conclua que o descumprimento tenha sido causado por ação intencional, a ECT deverá recolher a multa correspondente.

ALÍNEA "A": A ECT, por determinação da autoridade que instaurou o processo administrativo, deverá acionar o responsável pela infringência das obrigações assumidas no presente Termo, administrativa e/ou judicialmente, a fim de ressarcir-se das multas que tenha pago, sem prejuizo das sanções disciplinares cabíveis:

PARÁGRAFO SEGUNDO: Caso o processo administrativo conclua que o descumprimento tenha sido causado por ação não intencional, aplicar-se-ão ao responsável as penalidades disciplinares cabíveis, previstas nas normas internas da ECT, não cabendo a aplicação de multa pecuniária.

PARÁGRAFO TERCEIRO: A omissão quanto à providência prevista no caput transfere a responsabilidade do ressarcimento ao Presidente da ECT, referente aos processos da Administração Central, e ao Diretor Regional, em relação aos processos da Diretoria Regional:

CLÁUSULA NONA: As obrigações contidas nas Cláusulas Segunda, Terceira e Quarta, caput, deverão ser implementadas dentro de 06 (seis) meses contados da data de . assinatura do TAC, para a Administração Central da ECT, e de 18 (dezoito) meses após a data de sua assinatura, para as Diretorias Regionais.

CLÁUSULA DÉCIMA: O presente Termo de Ajustamento de conduta não impede a adoção de outras providências judiciais e extrajudiciais reputadas cabiveis visando o aperfeiçoamento deste Instrumento, assim cnıno não exclui a eventual responsabilidade criminal, civil e administrativa dos agentes públicos e terceiros responsáveis pelo ilícito na forma da legislação em vigor,

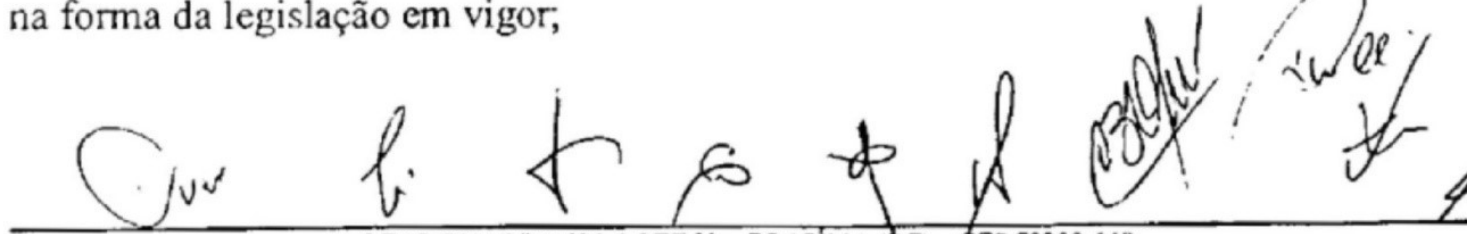


MINISTÉRIO PÚBLICO FEDERAL

PROCURADORIA DA REPÚBLICA NO DISTRITO FEDERAL

Nada mais havendo a ajustar, encerra-se o presente Termo, lavrado em duas vias originais, rubricadas e assinadas pelas pessoas abaixo nominadas.

Brasilia, 21 de outubro de 2010.<smiles>C1CCCCCC1</smiles>

BRUNQ CAIADO DE ACIOLI

Procurador da República

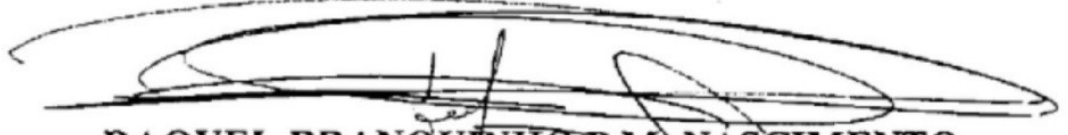

RAQUEL BRANQUINHO P.M.NÁSEIMENTO

Procuradora da Repúblióa

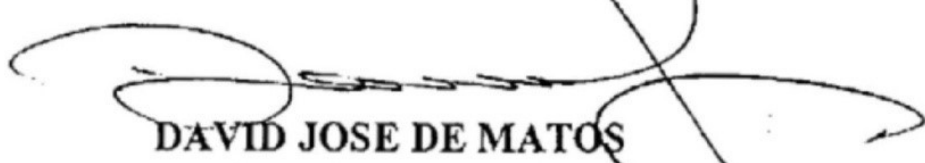

Presidente da ECT

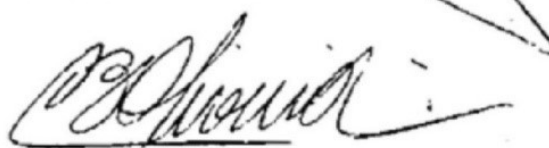

DÉCIO BRAGA DE OLIVEIRA

Diretor Econômico Financeiro

JOSÉ OSVALDO FONTOURA CARVALHO SOBRINHO

Diretor de Tecnologia e Infra-Estrutura

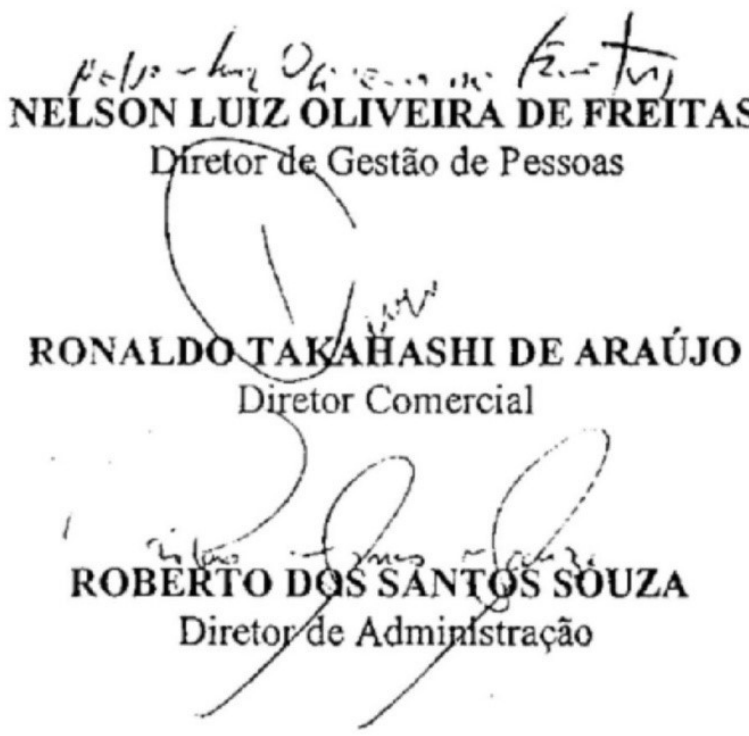


MINISTÉRIO PÚBLICO FEDERAL

PROCURADORIA DA REṔÚBLICA NO DISTRITO FEDERAL

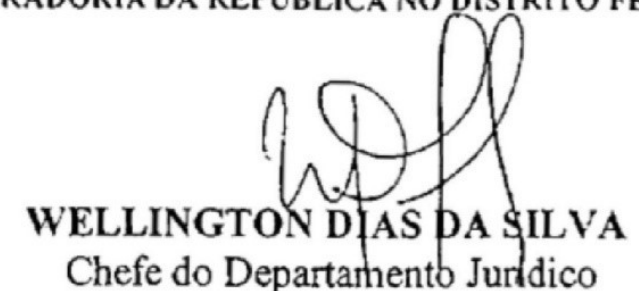

$\omega^{\prime}-j$

GERVÁSIO ALENCARYAO CANABARRO DE CARVALHO

Chefe de Gabinete do Presidente 
Anexo II - Relatório da VIPAD - 009/2011, de 15/08/2011 

Aprovado
Retirado
Rejeitado
$\square$ Em Vistas

IDENTIFICAÇÃO: Relatório/VIPAD-009/2011

REUNIÃO: REDIR-033/2011

DATA REUNIÃO: $15 / 08 / 2011$

ASSUNTO: Adesão da ECT ao Cadastro Nacional de Unidades Protocolizadoras da Administração Pública Federal.

\section{PROPOSTA}

Aprovar a adesão da ECT ao Cadastro Nacional de Unidades Protocolizadoras da Administração Pública Federal, conforme previsto na Portaria $\mathrm{n}^{\circ}$. 3 da SLTI/MPOG, de 16/05/2003.

\section{INDICATIVO DE COMPETÊNCIA}

Diretoria-Executiva, conforme alínea "a", inciso III, art. 23 do Estatuto.

\section{DESCRIÇÃO RESUMIDA DO CONTEÚDO.}

O TERMO DE AJUSTAMENTO DE CONDUTA (TAC) - Inquérito Civil $\mathrm{N}^{\circ}$ 1.16.000.000919/2005/09, assinado pela ECT e o Ministério Público Federal em 21/10/2010 refere-se a procedimentos relacionados à fiscalização, autuação e arquivamento de processos de contratação e de gestão de contratos no contexto da Lei 8.666/93 e da Lei 9.784/99.

Com o objetivo de cocrdenar as atividades relacionadas ao referido Termo foi constituído Grupo de Trabalho específico, bem como outros grupos temáticos no âmbito da VIPAD, de acordo com as diversas demandas relativas às cláusulas do TAC. 
Dentre as citadas cláusulas, a segunda diz respeito à instrução, autuação e arquivamento de processos de licitação e gestão de contratos, tendo como base os artigos 38 e 60 da Lei 8.666/93 e Artigo $22 \S 4^{\circ}$ da Lei 9.784/99.

Realizada a avaliação quanto aos procedimentos adotados na ECT para a formação de processos de contratação e de gestão de contratos, constatou-se que existem alguns aspectos que precisam ser revistos, de forma a atender a todos os requisitos relativos à instrução, autuação e arquivamento. Destaca-se que a Lei 9.784/99 - que regula o processo administrativo no âmbito da Administração Pública Federal - no art. 22 define os elementos que devem ser observados para a perfeita instrução dos processos administrativos.

Observa-se que a ECT atualmente não trabalha integralmente sob a ótica de formação de processos, ou seja, há casos de assuntos que deveriam tramitar como "processos administrativos", mas são tratados em diversas fases como uma série de documentos não integrados, muitas vezes resultando na perda da visão completa do tema e da qualidade e/ou velocidade do processo decisório. Como exemplos desta situação podem ser citados os casos em que uma CI tramita de forma avulsa, fazendo referência a diversas outras CI's ou documentos, sem que tais expedientes estejam tramitando em conjunto naquela oportunidade.

Assim, neste contexto, como o TAC em comento está direcionado especificamente aos processos de contratação e de gestão de contratos no âmbito da ECT, observa-se que é importante e necessário um movimento mais amplo nesta oportunidade, de forma a abarcar a formação de processos administrativos em geral na Empresa, aproveitando o momento para tratar cientificamente este tema, independente do assunto a que estiver relacionado cada processo administrativo a ser aberto na ECT.

Dentre as atividades relacionadas à formação dos processos administrativos, a inicial, e que se reveste de fundamental importância, é a que diz respeito à protocolização de cada processo. Hoje na ECT não existe um sistema de protocolo geral efetivamente consolidado, uma vez que no GDC (Sistema de Gestão de Documentos Correntes) este módulo encontra-se em fase de desenvolvimento/disponibilização por técnicos pertencentes às equipes de órgãos vinculados à VIPAD e VITEC.

Desta forma, após a realização de benchmarking em alguns órgãos (Ministério das Comunicações, CGU e Marinha do Brasil) pelo grupo de trabalho que está conduzindo este tema verificou-se que a alternativa mais indicada seria a continuidade de implantação do GDC que já se encontrava em curso, mediante a utilização do NUP (Número Único de Processo), nos termos previstos no 
Cadastro Nacional de Unidades Protocolizadoras da Administração Pública Federal, tendo como fundamento o art. $7^{\circ}$ da Portaria $n^{\circ} .3$ da SLTI/MPOG, de $16 / 05 / 2003$ (anexo 01).

A mencionada portaria destina-se a orientar os órgãos da Presidência da República, Ministérios, autarquias e fundações integrantes do Sistema de Serviços gerais - SISG, quanto aos procedimentos relativos às atividades de comunicações administrativas, para utilização do número único de processos e documentos. Em seu art. $7^{\circ}$ está previsto que as Empresas Públicas poderão adotar a sistemática de numeração única de processo, mediante solicitação de cadastramento no Ministério ao qual estão vinculadas.

Em vista do exposto, o presente relatório está sendo apresentado para deliberação da Diretoria-Executiva quanto à proposta de adesão da ECT ao Cadastro Nacional de Unidades Protocolizadoras da Administração Pública Federal, tomando por base proposição apresentada pelo Grupo de Trabalho que conduziu este tema (Relatório Técnico - Grupo GDC-001/2011 - anexo 02).

Uma vez aprovada a adesão, será enviado Ofício ao Ministério das Comunicações informando da decisão da ECT e solicitando o respectivo cadastramento ao Ministério do Planejamento, Orçamento e Gestão.

A Vice-Presidência de Administração posiciona-se favorável à adesão da ECT ao Cadastro Nacional de Unidades Protocolizadoras da Administração Pública Federal, conforme previsto no art. $7^{\circ}$ da Portaria $n^{\circ}$. 3 da SLTI/MPOG, de $16 / 05 / 2003$.

\section{IMPLICAÇÕES FINANCEIRAS}

Não há implicação financeira direta para utilização do NUP pela ECT, bastando a formalização do uso ao Ministério das Comunicações, que por sua vez se encarregará da solicitação de cadastramento junto ao MPOG.

\section{CRONOLOGIA DE IMPLEMENTAÇÃO}

Imediata para envio do Ofício ao Ministério das Comunicações, sendo que a utilização efetiva do NUP se dará conforme cronograma a ser elaborado pelo Grupo de Trabalho responsável pela implantação do protocolo único na ECT e a abrangência deste. 


\section{FUNDAMENTAÇÃO LEGAL E NORMATIVA}

Estatuto da ECT

\section{INFORMAÇÕES COMPLEMENTARES}

De acordo com o conteúdo da citada Portaria ${ }^{\circ}$ 3/2003 da SLTI/MPOG, para a utilização da sistemática de numeração única de processo foram definidas faixas numéricas de codificação de unidades protocolizadoras, relativas aos órgãos integrantes do SISG. Para o Ministério das Comunicações foi definida a faixa de 53000 a 53999. Após consulta àquele Ministério foi proposto que a ECT utilize a numeração de 53100 a 53199.

O NUP - Número Único de Processo é constituído de uma série de 17 dígitos, separados em 04 grupos sequenciais, com as seguintes características:

a) $00000.000000 / 0000-00$;

b) $1^{\circ}$ grupo: os 5 primeiros dígitos: 00000 - código numérico atribuído a cada unidade protocolizadora e este código identifica o órgão de origem do processo, mantendo-se inalterado - ECT - 53100 a 53199 (as dezenas serão utilizadas pela AC e Diretorias Regionais). No anexo 02 - relatório técnico do grupo de trabalho - há o detalhamento da numeração completa prevista para a ECT para a classificação de suas unidades;

c) $2^{\circ}$ grupo: os 6 próximos dígitos: 000000 - determinam o registro sequencial dos processos autuados, devendo este número ser reiniciado a cada ano;

d) $3^{\circ}$ grupo: os 4 próximos dígitos: 0000 - indicam o ano de formação do processo; e

e) $4^{\circ}$ grupo: os 02 próximos dígitos: 00 - indicam os dígitos verificadores (DV), utilizados pelos órgãos que façam uso de rotinas automatizadas.

Informa-se que a implantação do sistema de protocolo geral, já no novo enfoque de instrução de processos administrativos, será realizada de maneira gradual na Administração Central, abrangendo a estrutura da Presidência e de cada uma das Vice-Presidências por vez, com seus respectivos órgãos vinculados, de forma a permitir a utilização da nova sistemática dentro de um ambiente de 
aprendizado continuado e com o mínimo de percalços possível. Uma vez consolidada a implantação na Administração Central, procedimento similar será adotado no âmbito de cada Diretoria Regional.

Todo o processo de implantação será precedido de ampla divulgação, disponibilização de apostilas com material técnico de procedimentos e realização de treinamentos de gestores e executores de cada órgão; será conduzido por equipe de implantação que atuará em conjunto com os técnicos de cada unidade da ECT que passar a adotar a nova sistemática.

Para o presente caso, entende-se que o tema prescinde de parecer do Departamento Jurídico, haja vista tratar-se de adesão da ECT ao Cadastro Nacional de Unidades Protocolizadoras da Administração Pública Federal e de não haver a necessidade de formalização de qualquer termo de ajuste bilateral entre as partes, mas tão somente o encaminhamento, pela ECT, da informação quanto ao uso ao Ministério das Comunicações, que por sua vez se encarregará da solicitação de cadastramento junto ao MPOG.

\section{ANEXOS}

1. Portaria $n^{\circ} .3$ da SLTI/MPOG, de 16/05/2003;

2. Relatório Técnico - Grupo GDC- 001/2011.

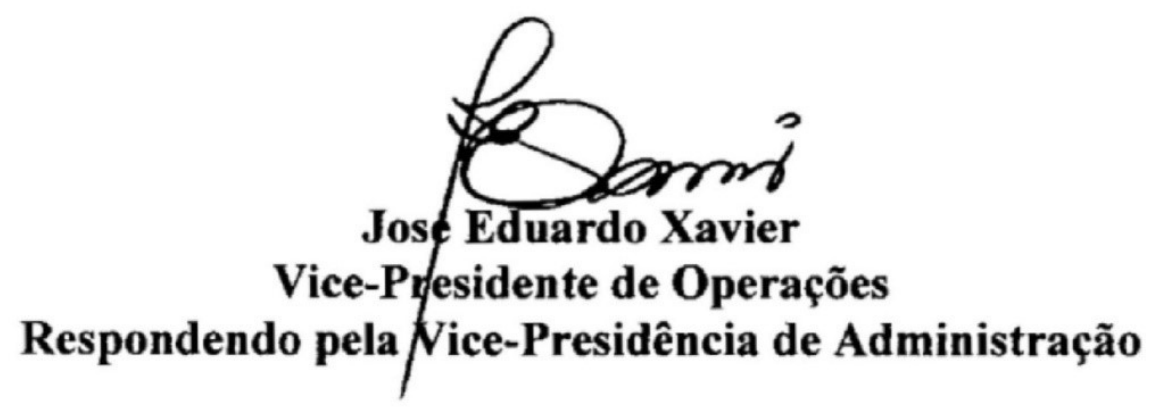


Anexo III - Pedido de Informação sobre o Mensalão - NUP 99923001883201434

Para: Ana Maria Ribeiro/UFRJ

Olá bom dia.

Ana Maria Ribeiro, pode usar sim, sem problemas, às informações são públicas e todos devem ter conhecimentos delas.

Caso, precise de outros dados da empresa, pois tenho muitos pedidos, favor entrar em contato. Quando terminar sua monografia me envia para apreciar a leitura.

Att

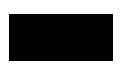

Em Dom 13/11/16 15:16, Ana Maria Ribeiro/UFRJ escreveu: Prezado Senhor Gilmar, Meu nome é Ana Maria de Almeida Ribeiro e fui, de maio de 2012 a maio de 2016, a Gerente do Serviço do Informação ao Cidadão dos Correios - GSIC-ECT, onde estava cedida. Sou servidora pública federal lotada na UFRJ, órgão para o qual retornei em junho deste ano.

Estou concluindo minha dissertação de Mestrado na UNB, no Programa de Pós-Graduação em Ciência da Informação e minha pesquisa trata da "Organização e Acesso a Informação na ECT após a promulgação da LAI". Estou entrando em contato com o senhor para Ihe solicitar autorização para utilizar a resposta que a ECT Ihe enviou como Transparência Passiva ao NUP 99923.001883/2014-34 que trata sobre o Mensalão. Em caso de positivo, solicito sua resposta a esta mensagem me autorizando o acesso e enviando o arquivo de resposta em anexo. O senhor pode baixar em PDF no seu acesso ao sistema e-SIC. Agradeço desde já sua colaboração.

Ana Maria Ribeiro Técnica em Assuntos Educacionais Universidade Federal do Rio de Janeiro/UFRJ

国 resposta solicitada.pdf $73 \mathrm{~K}$ 


\section{Dados do Pedido}

Protocolo

Solicitante

Data de Abertura

Orgão Superior Destinatário

Orgão Vinculado Destinatário

Prazo de Atendimento

Situação

Status da Situação

Forma de Recebimento da Resposta Pelo sistema (com avisos por email)

ResumoDevolução de dinheiro mensalão DetalhamentoOlá bom dia.

Gostaria de saber, em relação ao caso mensalão que ocorreu nos Correios, se houveram demissões de servidores da empresa? Se sim, quais? Ainda se houve algum dinheiro estatal desviando? Se sim? foram devolvidos? Quanto? Existe processos internos referente ao caso mensalão atualmente? Se sim, quais?

Att 


\section{Dados da Resposta}

Data de Resposta

Tipo de Resposta

Classificação do Tipo de Resposta

Resposta

Responsável pela Resposta

Destinatário do Recurso de Primeira Instância:

Prazo Limite para Recurso

\section{$22 / 12 / 2014$ 15:14}

Acesso Parcialmente Concedido

Parte da informação contém dados pessoais

Prezado Senhor

Informamos que todas as denúncias relacionadas ao caso do Mensalão, envolvendo empregados desta Empresa Pública foram apuradas, em conformidade às normas sobre a matéria. Os trabalhos foram acompanhados pela Controladoria Geral da União e Ministério Público Federal.

Em decorrência do apurado, ocorreram 12 (doze) demissões. A empresa está impossibilitada de divulgar os nomes dos ex-empregados tendo em vista tratar-se de informação de cunho pessoal, sendo sua divulgação vedada pela própria Lei de Acesso à Informação em seus artigos 6으, inciso III e 31, pois possui acesso restrito.

Quanto aos valores envolvidos, não foi constatado valor desviado da estatal. No entanto, em decorrência de atos praticados por empresas contratadas à época, foram adotadas providências judiciais visando cobranças de valores na ordem de $\mathrm{R} \$ 1.667 .571,08$.

Na presente data existem ainda em andamento dois processos que tiveram origem no Mensalão, processos NUP 53101.005366/2013-26 e NUP 53101.007297/2012-12, de natureza disciplinar, portanto, de caráter restrito.

Os Correios agradecem a sua compreensão.

Chefe do Departamento de Controle Disciplinar

Eventuais recursos devem ser dirigidos ao Vice-Presidente Jurídico, de acordo com o Art. 21 do Decreto 7.724/2012 que regulamenta a Lei de Acesso a Informação - Lei 12.527/2011, no prazo de 10 dias, a contar do recebimento desta resposta.

Serviço de Informação ao Cidadão

Empresa Brasileira de Correios e Telégrafos

Classificação do Pedido 
Anexo IV - Manual de Comunicação, Módulo 7, Capítulo 3 


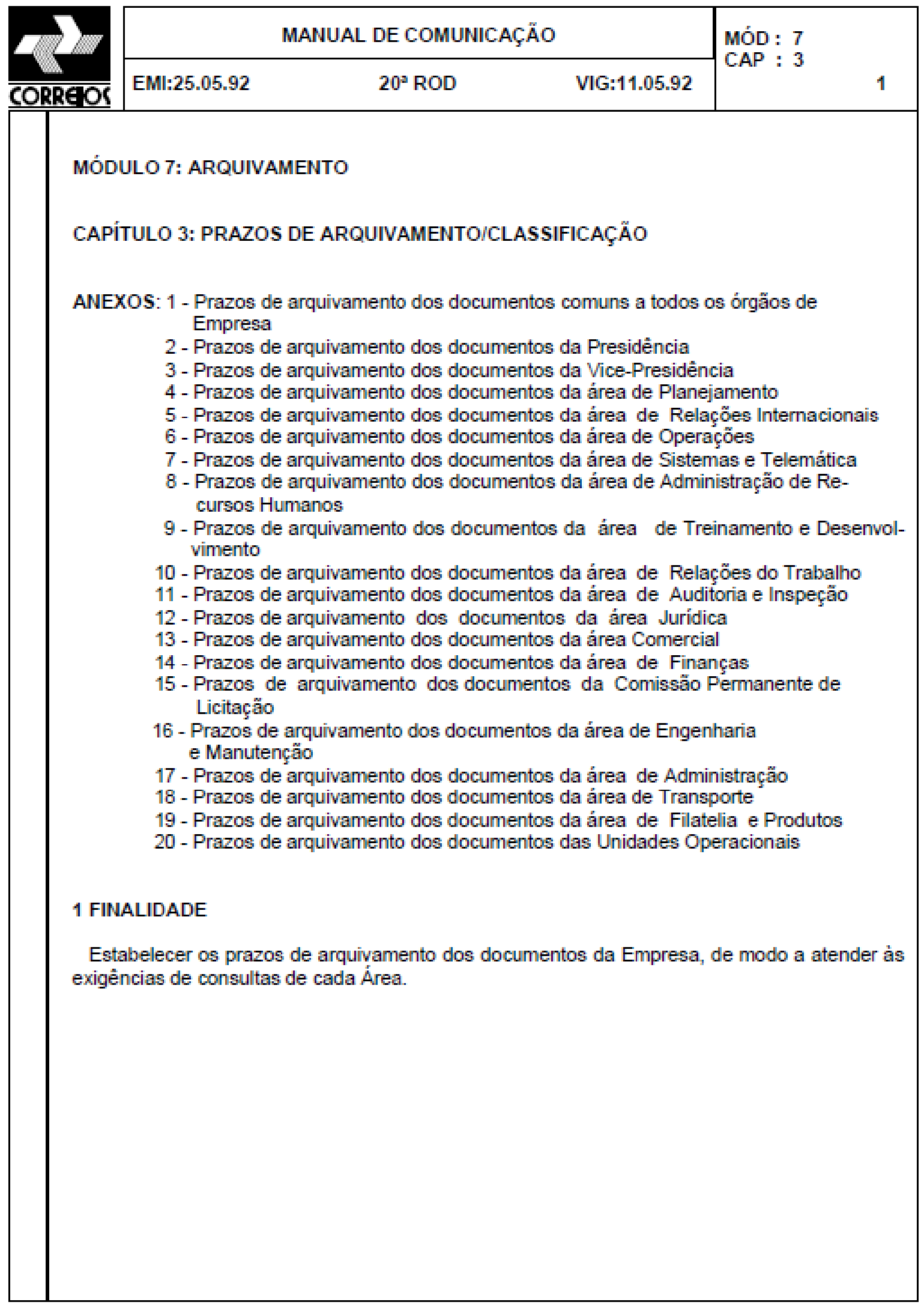




\section{OBSERVÂNCIA DOS PRAZOS DE ARQUIVAMENTO}

Os prazos estipulados para arquivar os documentos deverão ser observados nas seguintes situaçöes:

a) quando da conclusão dos assuntos neles tratados;

b) após o cumprimento da finalidade a que se destinam;

c) por ocasião do encerramento do exercício.

\section{CLASSIFICAÇÃO DOS DOCUMENTOS}

3.1 A classificação dos documentos é determinada de acordo com os seguintes critérios:

\begin{tabular}{|c|c|c|}
\hline \multirow{2}{*}{ GRUPO } & \multicolumn{2}{|c|}{ ARQUIVAMENTO (MESES) } \\
\cline { 2 - 3 } & NO ÓRGÄO & $\begin{array}{c}\text { NO ARQUIVO } \\
\text { CENTRAL }\end{array}$ \\
\cline { 2 - 3 } & & \\
A & 24 & PERMANENTE \\
B & 12 & PERMANENTE \\
C & 24 & 60 \\
D & 12 & - \\
E & 24 & - \\
F & 18 & - \\
G & 15 & - \\
H & 12 & - \\
I & 06 & - \\
J & 04 & \\
L & 01 & \\
\hline
\end{tabular}

3.2 Catálogos de cursos, prospectos, "folders" e listas telefônicas não fazem parte do arquivo e devem arquivar-se na chefia ou ser descartados.

3.3 Os documentos que contenham determinação legal e os que possam contribuir para a formar o patrimônio histórico e cultural da ECT arquivam-se por prazo indeterminado e classificam no Grupo "A".

3.4 Os documentos, cujas informações possam vir a ser objeto de consulta, após cumprir seus objetivos, que não estiverem sujeitos a imposições legais, classificam-se no Grupo "B".

3.5 Os demais documentos serão classificados nos Grupos " $\mathrm{C}$ " a "L. 


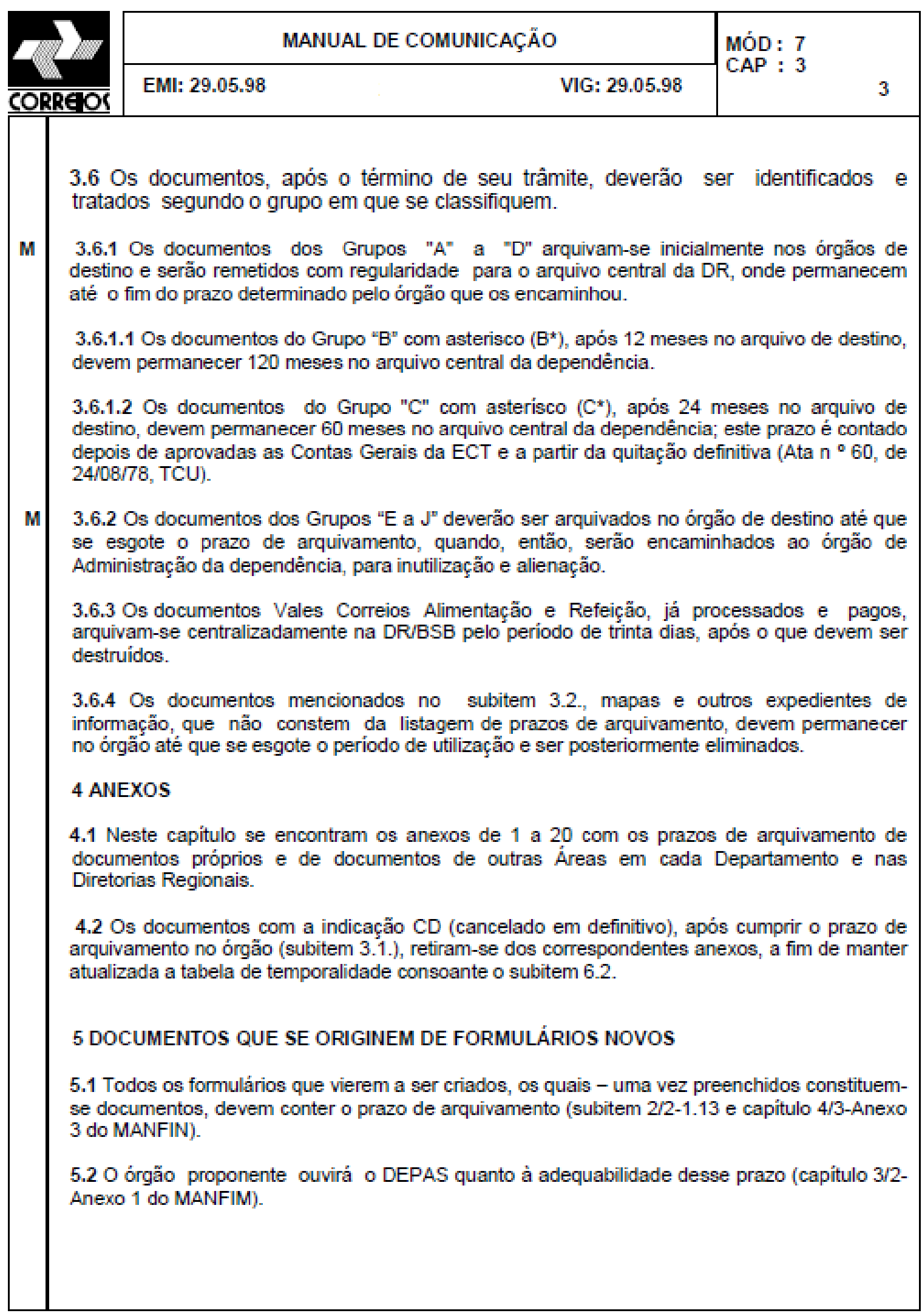




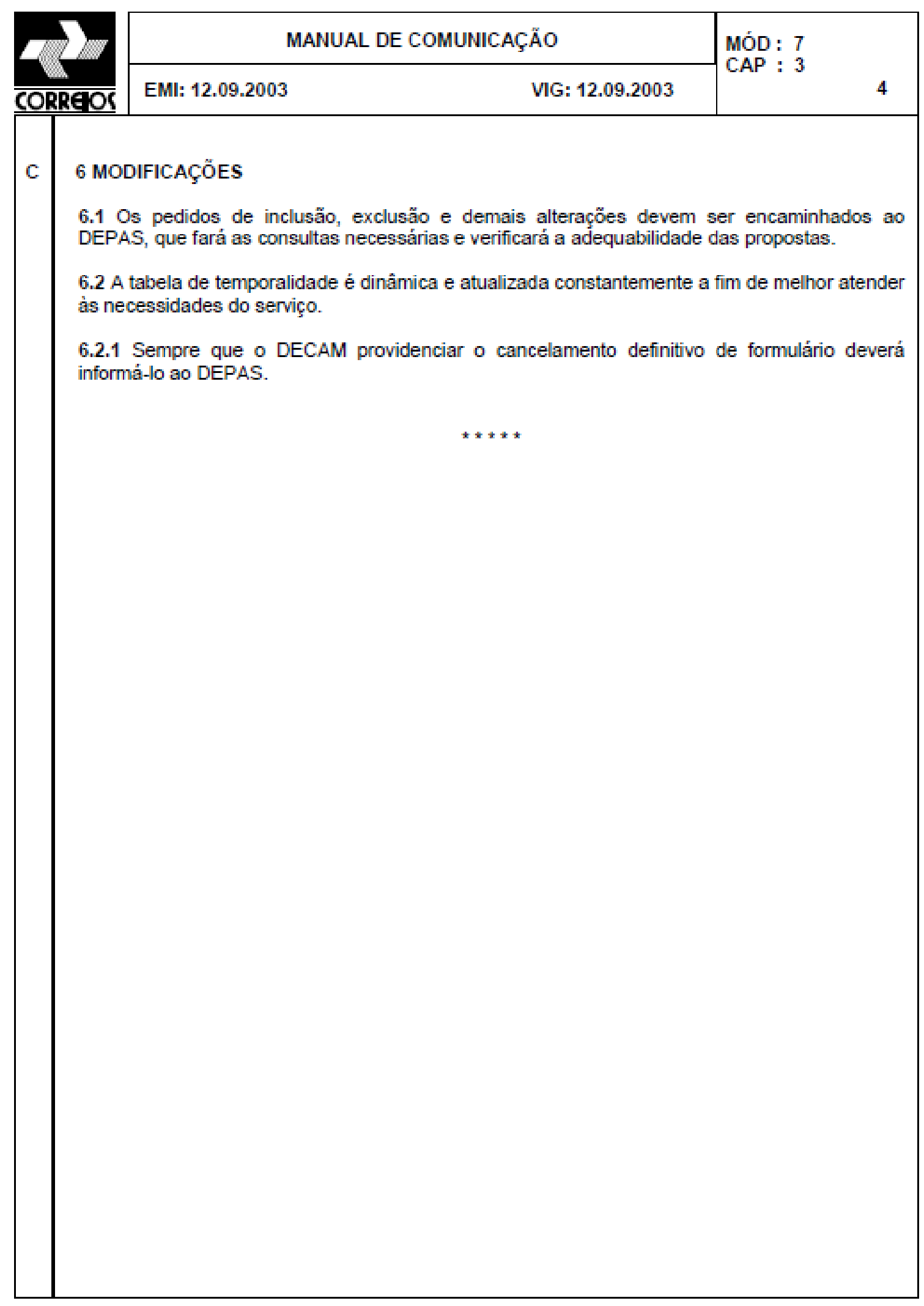




\section{Monitoramento da Implementação da Lei de Acesso às Informações}

Departamento de Coordenação e Governança das Empresas Estatais

Coordenação de Avaliação de Empresas

$02 / 05 / 2012$ 


\section{Monitoramento}

- Reunião: Casa Civil, CGU e DEST - 06 de março de 2012

DEST/MP: acompanhar a implementação de cada uma das etapas previstas no cronograma, por meio de relatório a ser enviado semanalmente para preenchimento pela Estatal.

Dúvidas operacionais da implementação da Lei: DEST/MP, que as responderá uma vez definidas as respostas.

Dúvidas e sugestões referentes à regulamentação da Lei: Casa Civil e CGU, com cópia para o DEST/MP

- Início do Monitoramento: 15/03

- Fase Atual: 60 checklist

- Fim do Monitoramento: 16/05 (data que a lei entra em vigor).

\section{DEST \\ Monitoramento}

\section{Por que semanalmente?}

- Lei entra em vigor em aproximadamente 40 dias;

- Necessário que toda a Administração esteja preparada (inclusive empresas);

- Mais fácil identificar riscos e saná-los a tempo.

\section{- Qual a utilidade desse Checklist:}

- Não é apenas ferramenta de controle;

- Nortear as atividades que devem ser feitas;

- Sanar dúvidas;

- Encontrar pontos críticos e resolvê-los. 


\section{Cronograma CGU - Empresas Estatais}

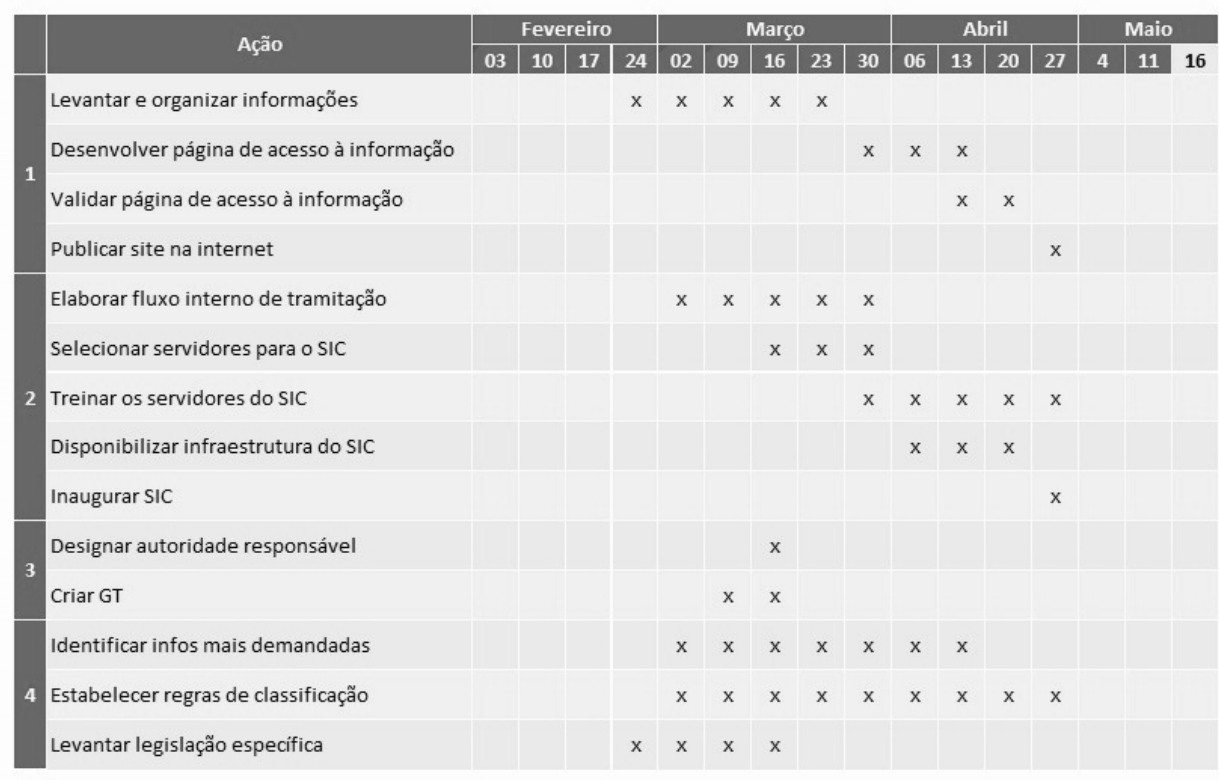

\section{PEST}

\section{Checklist}

$\left.\begin{array}{c|l}\text { As respostas dos itens abaixo } \\ \text { deverão variar entre: }\end{array}\right] \begin{aligned} & \text { - Não Iniciado } \\ & \text { - Iniciado } \\ & \text { - Avançado } \\ & \text { - Concluído }\end{aligned}$

\begin{tabular}{|c|c|c|c|}
\hline ITENS DO CRONOGRAMA & Prazo & Respostas & COMENTÁRIO/DÚVIDAS \\
\hline Levantar e organizar informações & $23 /$ mar & Não Iniciado & \\
\hline Desenvolver página de acesso à informação & $13 / a b r$ & Não Iniciado & \\
\hline Validar página de acesso à informação & 20/abr & Não Iniciado & \\
\hline Publicar site de acordo com a LAI na internet & $27 / a b r$ & Não Iniciado & \\
\hline Elaborar fluxo interno de tramitação de pedidos de acesso & 30/mar & Não Iniciado & \\
\hline Selecionar servidores para o SIC & 30/mar & Não Iniciado & \\
\hline Treinar os servidores do SIC & 27/abr & Não Iniciado & \\
\hline Dis ponibil izar infraestrutura do SIC dentro da empresa & 20/abr & Não Iniciado & \\
\hline Inaugurar SIC & $27 / a b r$ & Não Iniciado & \\
\hline Designar autoridade responsável no D.O.U. & $16 /$ mar & Não Iniciado & \\
\hline Criar e publicar GT no D.o.u. & $16 /$ mar & Não Iniciado & \\
\hline Identificar infos mais demandadas & $13 / \mathrm{abr}$ & Não Iniciado & \\
\hline Estabelecer regras de cl assificação de informaçães & $27 / \mathrm{abr}$ & Não Iniciado & \\
\hline Levantar legisl ação es pecífica sobre hi póteses legais de sigilo & $16 /$ mar & Não Iniciado & \\
\hline
\end{tabular}




\section{Checklist}

- Itens do Guia para atualização do Site, disponibilizado pela CGU.

\begin{tabular}{c|l} 
As respostas dos itens abaixo \\
deverão variar entre:
\end{tabular}$\quad \begin{aligned} & \text { - Não se aplica } \\
& \text { - Não Iniciado } \\
& \text { - Iniciado } \\
& \text { - Avançado } \\
& \text { - Concluído }\end{aligned}$

\begin{tabular}{|c|c|c|}
\hline Status do levantamento das informações dos itens do Guia & Respostas & COMENTÁRIO/DÚVIDAS \\
\hline 1-Institucional & Não Iniciado & \\
\hline 2-Ações e programas & Não Iniciado & \\
\hline 3-Auditorias & Não Iniciado & \\
\hline 4- Convênios & Não Iniciado & \\
\hline 5-Despesas & Não Iniciado & \\
\hline 6- Licitações e Contratos & Não Iniciado & \\
\hline 7-Servidores/Empregados & Não Iniciado & \\
\hline 8- Perguntas Frequentes & Não Iniciado & \\
\hline 9-Serviço de Informações ao Cidadão - SIC & Não Iniciado & \\
\hline
\end{tabular}

\section{Resultados - Checklist}

\begin{tabular}{|c|c|c|c|c|c|c|}
\hline Cód. & Ação & Prazo & Não Iniciado & Iniciado & Avançado & Concluido \\
\hline & Leva ntare organi zar informações & $23 / \mathrm{mar}$ & $0 \%$ & $16 \%$ & $36 \%$ & $43 \%$ \\
\hline & Abastecer site padroniza do & $13 / a b r$ & $0 \%$ & $11 \%$ & $57 \%$ & $27 \%$ \\
\hline & Validar site e conteúdo & $20 / a b r$ & $16 \%$ & $25 \%$ & $32 \%$ & $23 \%$ \\
\hline 1.d & Publicar site na internet & $27 / a b r$ & $27 \%$ & $20 \%$ & $27 \%$ & $20 \%$ \\
\hline 2.a & Elabora r fl uxo interno de tra mi tação & $30 / \mathrm{mar}$ & $5 \%$ & $16 \%$ & $30 \%$ & $45 \%$ \\
\hline 2.b & Selecionar servidores para o SIC & $30 / \mathrm{mar}$ & $7 \%$ & $14 \%$ & $16 \%$ & $59 \%$ \\
\hline $2 . c$ & Trei nar os servidores do SIC & $27 / a b r$ & $14 \%$ & $23 \%$ & $20 \%$ & $39 \%$ \\
\hline 2.d & Disponibilizar infraestrutura do SIC & $20 / a b r$ & $7 \%$ & $25 \%$ & $32 \%$ & $32 \%$ \\
\hline 2.e & Inaugurar SIC & $27 / a b r$ & $41 \%$ & $11 \%$ & $30 \%$ & $11 \%$ \\
\hline & Designar a utorida de res ponsável & $16 /$ mar & $5 \%$ & $0 \%$ & $20 \%$ & $70 \%$ \\
\hline & CriarGT & $16 /$ mar & $2 \%$ & $2 \%$ & $16 \%$ & $75 \%$ \\
\hline \multirow{3}{*}{$\begin{array}{l}\text { 4.a } \\
\text { 4.b } \\
\text { 4.c }\end{array}$} & Identificar infos mais demanda das & $13 / a b r$ & $2 \%$ & $18 \%$ & $11 \%$ & $64 \%$ \\
\hline & Esta belecer regras de cl ass ifica ção & $27 / a b r$ & $11 \%$ & $43 \%$ & $30 \%$ & $11 \%$ \\
\hline & Leva ntar le gis lação e spe cífica & $16 /$ mar & $9 \%$ & $25 \%$ & $18 \%$ & $43 \%$ \\
\hline
\end{tabular}

\begin{tabular}{|c|c|c|c|c|}
\hline & Năo Iniciado & Iniciado & Avança do & Concluido \\
\hline Institucional & $2 \%$ & $11 \%$ & $43 \%$ & $39 \%$ \\
\hline Açóes e programas & $7 \%$ & $14 \%$ & $48 \%$ & $25 \%$ \\
\hline Auditorias & $2 \%$ & $16 \%$ & $30 \%$ & $48 \%$ \\
\hline Convênios & $5 \%$ & $16 \%$ & $20 \%$ & $41 \%$ \\
\hline Despesas & $2 \%$ & $20 \%$ & $32 \%$ & $39 \%$ \\
\hline Licitaçôes e Contra tos & $2 \%$ & $11 \%$ & $36 \%$ & $45 \%$ \\
\hline Empregados & $2 \%$ & $25 \%$ & $25 \%$ & $41 \%$ \\
\hline Perguntas Frequentes & $7 \%$ & $20 \%$ & $30 \%$ & $36 \%$ \\
\hline SIC & $7 \%$ & $36 \%$ & $20 \%$ & $32 \%$ \\
\hline
\end{tabular}




\title{
Obrigado!
}

\author{
Contatos: \\ Vitor Fachini \\ $61-2020-5089$
}

Email: vitor.fachini@planejamento.gov.br 
Anexo VI - Apresentação do Ministério das Comunicações, dia 3 de maio de 2012

\section{Ministério das Comunicações}

Lei 12.527, de 18 de novembro de 11

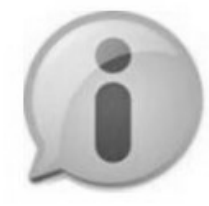

\section{Acesso à}

Informação

Danilo Bertazzi

Secretaria-Executiva

Brasília, 03 de maio

\section{Acessod}

\section{AGENDA}

- Histórico do acesso à informação

- Acesso à informação para quê?

- Mudança na lógica da administração

- Implantação da lei de acesso no MC e vinculadas

- Oportunidades 


\section{HISTÓRICO}

-1988: Garantia do direito de acesso na Constituição

-1991: Política Nacional de arquivos públicos e privados

-2000: Lei de Responsabilidade Fiscal: LC101

-2002: Decreto 4.553, salvaguarda de documentos

sigilosos - sigilo eterno

-2004: Decreto $n^{0} 5.301$ restabelece limites para sigilo

-2005: Portal da Transparência

-2007: Portal dos Convênios

-2009: Lei Capiberibe e Carta de Serviços ao Cidadão

-2010: Cadastro Nacional de Empresas Inidôneas e

Suspensas

Ministério das Comunicações

\section{Acessob̀
Informaşo}

\section{HISTÓRICO}

2003

Gestão pública participativa, mudança no modo de formular, implementar e avaliar políticas públicas
73 conferências nacionais, Criação e fortalecimento de conselhos, fóruns, mesas de diálogo e ouvidorias

2011

A Lei de acesso à informação consolida um novo tipo de relação entre o Estado e a Sociedade, pautada na abertura e na transparência 
(i) Acessod

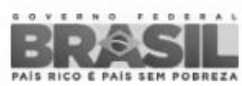

ACESSO À INFORMAÇÃO PARA QUÊ?

-Direito necessário para exercer outros direitos (saúde,educação, etc)

- Conhecer o passado e acertar as contas com a história (Comissão da Verdade)

-Melhorar a gestão e qualidade do gasto e dos serviços públicos

-Aumentar a prevenção e o combate à corrupção

-Aumentar a participação e o controle social

-Desenvolvimento de novas tecnologias

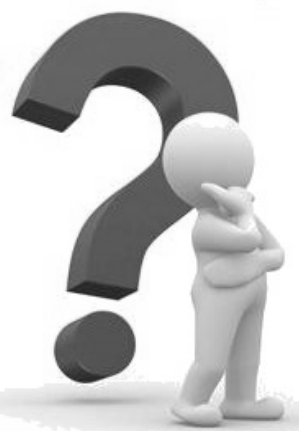

Ministério das Comunicações

Intormaşà

MUDANÇA DA LÓGICA NAADMINISTRAÇÃO

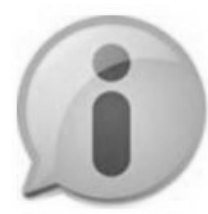

Acesso à

Informação

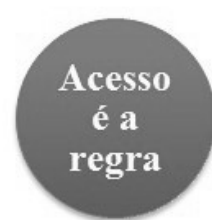

Sigilo é

a

exceção 
(i) $\begin{gathered}\text { Acessod } \\ \text { informasso }\end{gathered}$

\section{PROMOÇÃO DA CULTURA DO ACESSO}

- Palestras sobre acesso à informação para cúpula do Ministério

- Comunicação sobre acesso à informação

- Oficinas sobre acesso à informação para servidores

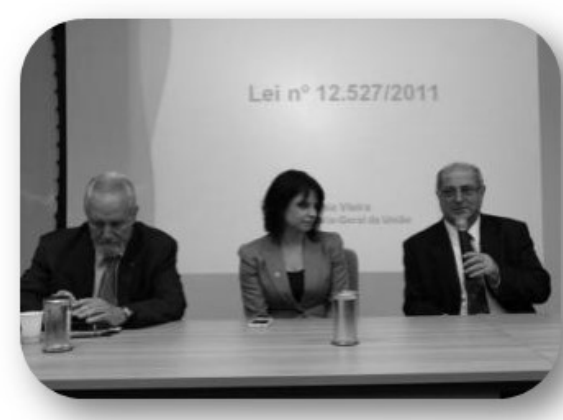

\section{Acessod}

\section{TRANSPARÊNCIA ATIVA}

- Levantamento e organização de informações mais demandadas

- Consulta externa

- Estruturação de novo site
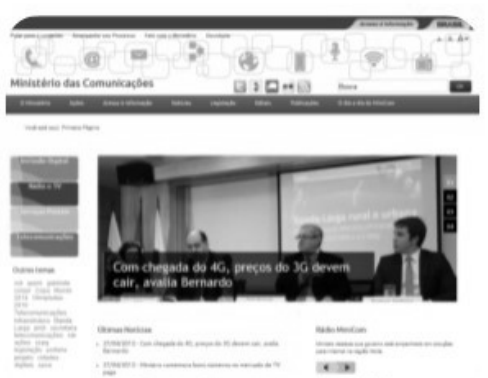
(i) Acessod

\section{TRANSPARÊNCIA PASSIVA}

- Implantar o Serviço de Informações ao Cidadão (SIC)

- Pedidos não precisam ser motivados.

- Pessoa física ou jurídica, brasileiro ou estrangeiro

- Prazo para resposta é de 20 dias +10 , justificadamente.

- $O$ fornecimento das informações é gratuito, sendo cobradas apenas as cópias.

- Negativa de acesso deve ser sempre justificada e podem ser feitos recursos.

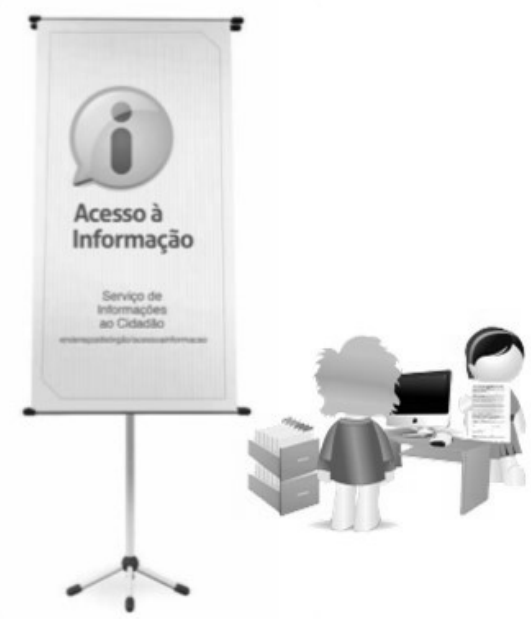

Acessod

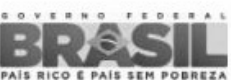

ORGANIZAÇÃO INTERNA

- Comitê de Organização de Informações

- Fluxo interno e procedimentos

- Infraestrutura para Serviço de Informações ao Cidadão

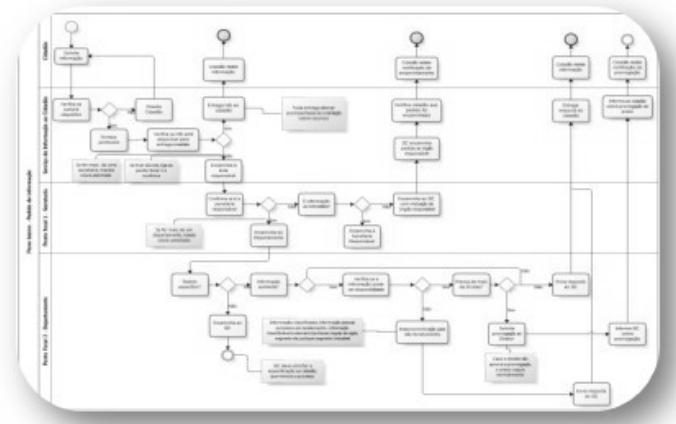

- Capacitação dos servidores do fluxo e do SIC 
(i) Acessod

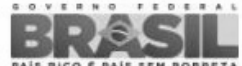

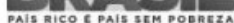

FLUXO PARA RESPOSTA A PEDIDOS DE INFORMAÇÃO

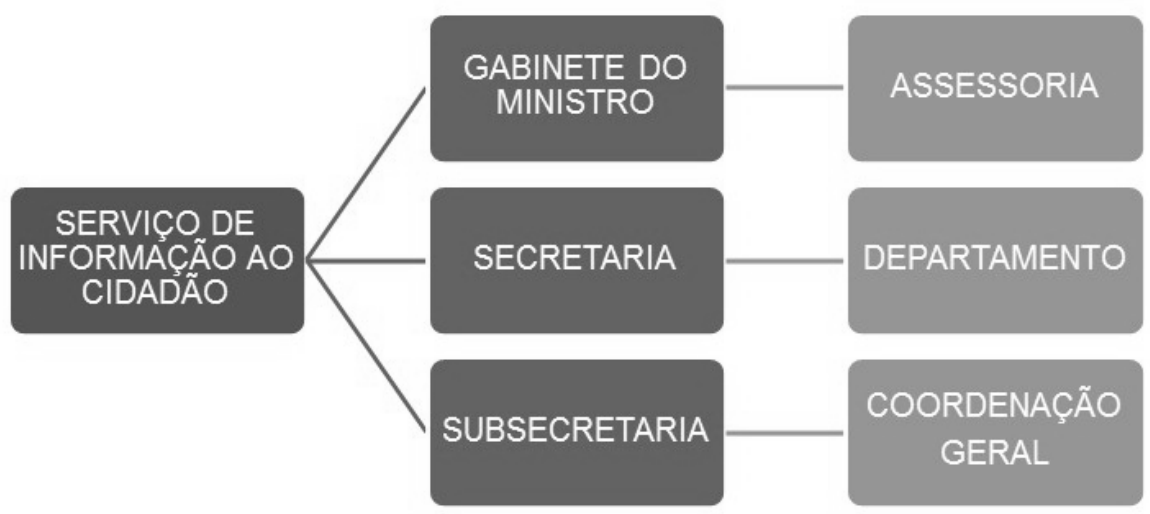

Ministério das Comunicações

\section{Acessod}

\section{A INFORMAÇÕES DE ACESSO RESTRITO}

- Levantamento de informações classificadas

- Levantamento de informações classificáveis

- Levantamento normas de sigilo aplicáveis ao MC e suas vinculadas

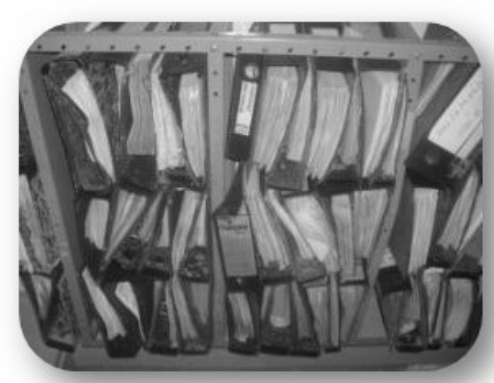




\section{ARTICULAÇÃO COM VINCULADAS}

- Comitê de monitoramento

- Intercâmbio de dados

- Troca de experiências

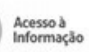

PONTOS FORTES X PONTOS FRACOS

\section{Pontos fortes}

- Apoio do Ministro e SecretárioExecutivo

- Participação de todas as áreas meio e fim

- Apoio CGU

- Levantamento externo de informações mais demandadas

- Demandas convergentes

- Articulação com vinculadas

\section{Pontos fracos}

- Desconhecimento do tema

- Resistência

- Déficit RH e TI

- Prazo exíguo

- Gestão de documentos e da informação

- Sistemas de informação

- Baixa produção de dados

- Processos para análise em estoque 


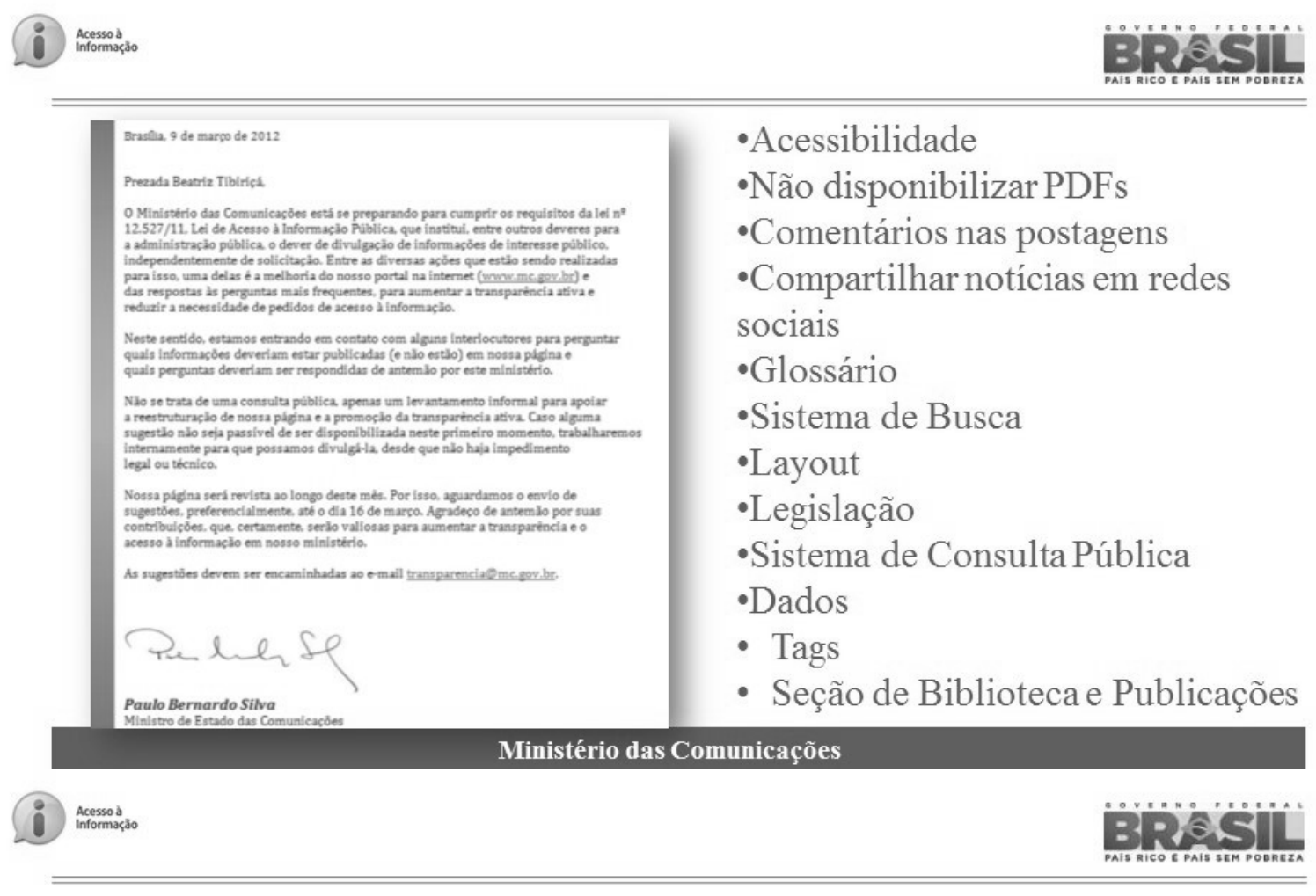

\section{OPORTUNIDADES}




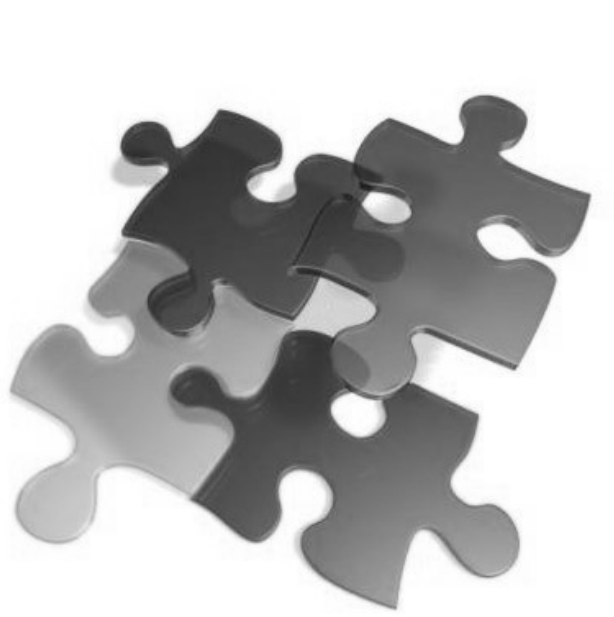

A IMPLEMENTAÇÃO DA LEI DE ACESSO EXIGE:

-Capacidade de gestão

-Investimentos tecnologia

-Compromisso político.

- O Brasil é considerado um país avançado na divulgação de dados públicos, em especial orçamentários. Esta liderança foi atestada quando o Brasil foi convidado a liderar, junto com os Estados Unidos, a Parceria para Governo Aberto (opengov partnership), um esforço global para fazer governos melhores, mais transparentes, mais efetivos e responsivos.

-A OGP começou com 8 países em setembro de 2011 e já conta com 54 compromissos.

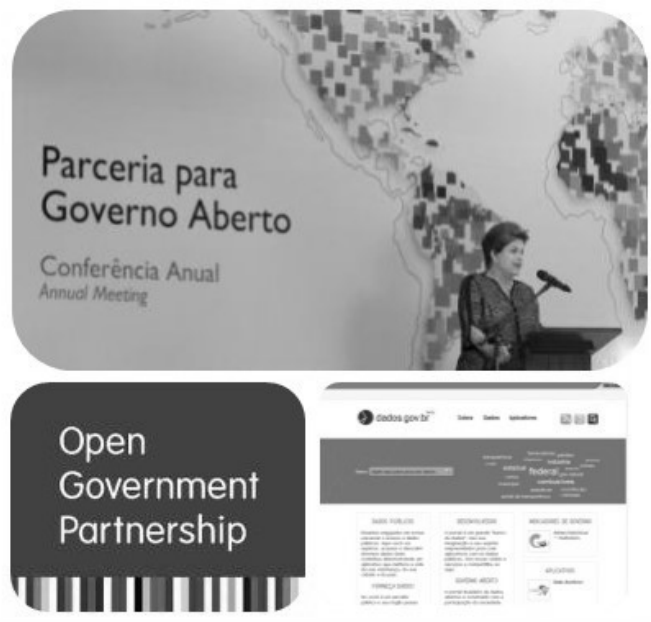


(i) Acessod

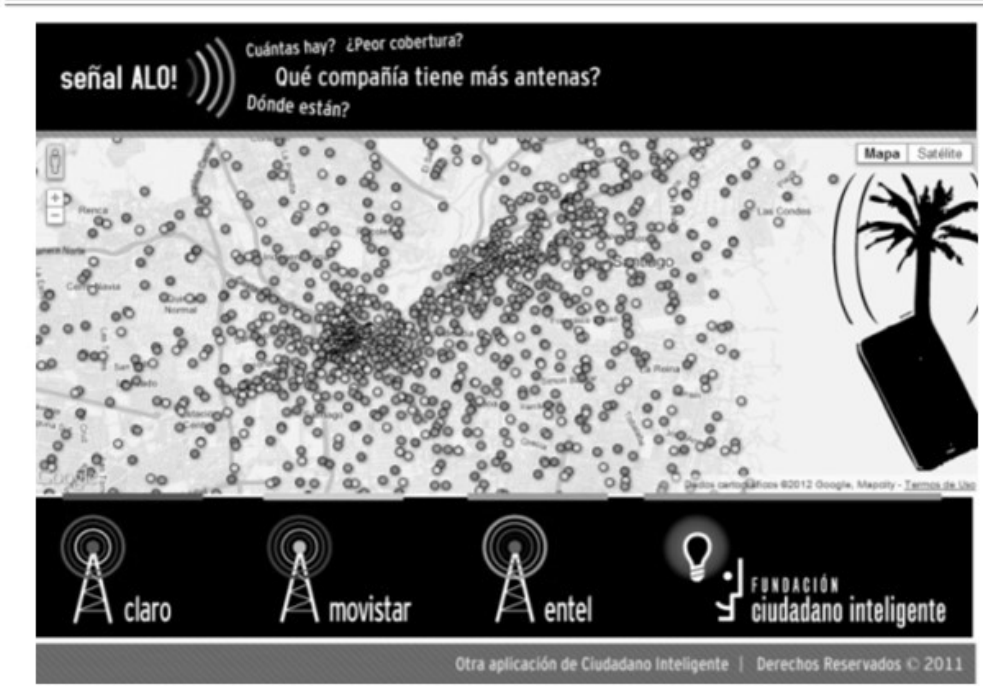

\section{DADOS ABERTOS}

Incentivo a que as empresas e a sociedade civil criem novas utilidades para as informações públicas que permitam ganhos sociais $\mathrm{e}$ econômicos.

\section{Ministério das Comunicações}

\section{Acessob}

-Conhecimento e informação são vantagens competitivas

-A informação gerada pelo setor público é fonte potencial para a expansão de serviços eletrônicos e conteúdos digitais.

-Reuso da informação pública e seu potencial para o BRBSil desenvolvimento social e econômico.

-Na União Europeia, a abertura dos dados faz parte da política de inovação e movimentou 40 bilhões de euros em EPSI platform 2011(geoprocessamento, meteorologia, prevenção de desastres, segurança pública) 
(i) $\begin{gathered}\text { Acessod } \\ \text { intomassobo }\end{gathered}$

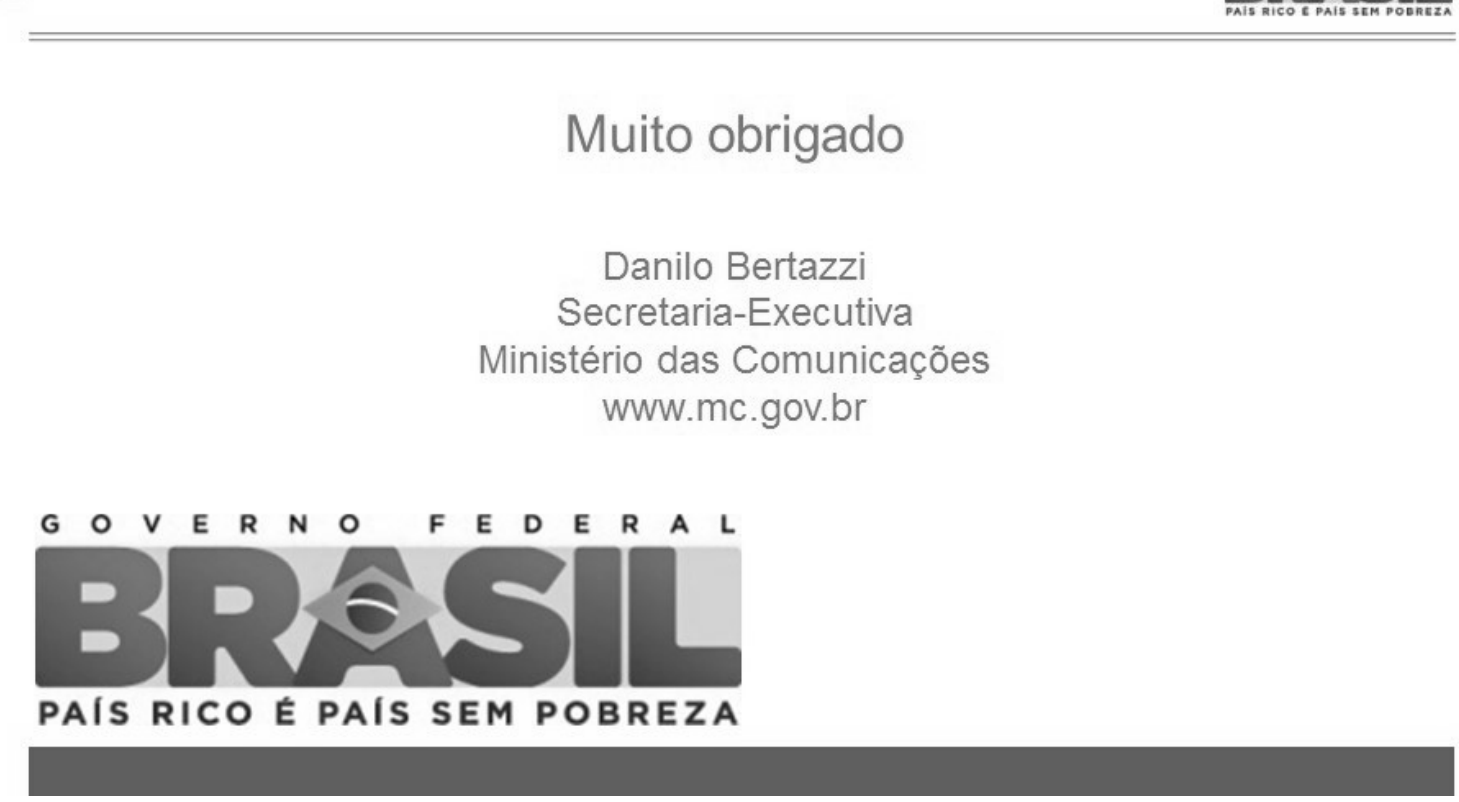

